\title{
EL ESTATUTO BÁSICO DEL EMPLEADO PÚBLICO
}

\author{
Jesús Ángel Fuentetaja Pastor \\ Profesor Titular de Derecho Administrativo \\ Universidad Nacional de Educación a Distancia
}

\begin{abstract}
I. El Estatuto Básico del Empleado PúBlico: 1. Estatuto. 2. Estatuto «Básico»: 2.1. Las bases del régimen estatutario de los funcionarios: 2.1.1. La noción formal de las bases del régimen estatutario de los funcionarios. 2.1.2. El contenido de las bases del régimen estatutario de los funcionarios. 2.2. El Estatuto Básico del Empleado Público en cuanto bases del régimen estatutario de los funcionarios: 2.2.1. La reducción de la densidad de la legislación básica. 2.2.2. Peculiaridades en el uso de la técnica básica del EBEP. 2.3. Las bases del régimen estatutario de los funcionarios fuera del EBEP. 2.4. El contenido no básico del EBEP. 3. Estatuto Básico del "Empleado Público».--II. Estatuto Básico y Comunidades Autónomas: 1. Legislación básica y legislación autonómica. 2. Legislación básica y Estatutos de Autonomía.-III. Estatuto Básico y LegIsLación Del Estado: 1. Legislación estatal de Función Pública como desarrollo del EBEP. 2. Legislación estatal de Función Pública como normativa supletoria.--IV. Estatuto BÁsico y Negociación colectiva: 1. Contenido de la negociación colectiva funcionarial. 2. Naturaleza de la negociación colectiva funcionarial y de los Pactos y Acuerdos. 3. Eficacia de la negociación colectiva funcionarial y de los Pactos y Acuerdos. 4. El carácter básico de la negociación colectiva funcionarial. - V. ESTATUTO BÁsICO Y CLASES DE PERSONAL: 1. Hacia una concepción sustantiva de los funcionarios. 2. La relación laboral de empleo público. 3. El personal directivo.-VI. EstatUTo BÁsIco y CARRERA: 1. Estructuración del empleo público. 2. La carrera como derecho. 3. La evaluación del desempeño.-VII. EstatuTo BÁSICO Y DERECHOS Y DEBERES.
\end{abstract}

\section{RESUMEN}

La Ley 7/2007, de 12 de abril, del Estatuto Básico del Empleado Público, constituye la legislación básica del régimen estatutario de los funcionarios prevista en el artículo 149.1.18. ${ }^{\mathrm{a}}$ de la Constitución, pero sólo una parte del «estatuto de los funcionarios públicos», cuya regulación por ley impone el artículo 103.3 de la Constitución. En este sentido, el nuevo Estatuto Básico se remite a la legislación de desarrollo (Estado y Comunidades Autónomas) para completar ese «estatuto», que gozará de un amplio margen de actuación en lo que se refiere a la estructura objetiva de la Función Pública (organización, ordenación de puestos de trabajo y funcionarios, carrera, etc.), pero más reducido en lo que respecta a los derechos y obligaciones de los empleados públicos. Será, pues, cada Administración quien defina su modelo de Función Pública.

Palabras clave: Función Pública; funcionario; empleado público; carrera.

\section{ABSTRACT}

The Act 7/2007, of 12 April, establishing the «Basic Status of Public Employees», lays down the basic rules of the status of civil servants (according to article 149.1.18. ${ }^{\mathrm{a}}$ of the Spanish Constitution), but only a part of «the legal status of civil servants» (art. 103.3 Constitution). The Legislation of the State and of the Self-Governing Communities will implement the new «Basic Status» with broader jurisdiction over the Civil Service structure (organisation of jobs and civil servants, career, etc.), but not so much as over the rights and duties of public employees. So each Public Administration will be responsible for defining its Civil Service System.

Key words: Civil Service; civil servant; public employee; career. 


\section{El Estatuto Básico del Empleado Público}

La aprobación de la Ley 7/2007, de 12 de abril, del Estatuto Básico del Empleado Público ${ }^{1}$, constituye un hito fundamental en la historia de la Función Pública en España y un punto de partida para todo un movimiento de reformas legislativas que dicha Ley impone.

Resultaba ya un lugar común afirmar que la aprobación del Estatuto de los Funcionarios era uno de los mandatos constitucionales pendientes de cumplir. La necesidad de un texto, formal y sustantivo, en ese sentido se agudizó por la consolidación de la descentralización política territorial, por la fragmentación y dispersión de la normativa de Función Pública y por una jurisprudencia constitucional que conminó al legislador estatal a aprobar definitivamente un marco básico postconstitucional al cerrar la puerta a las inferencias materiales de la legislación preconstitucional ${ }^{2}$.

Para el análisis y comprensión de la Ley 7/2007 es necesario partir del importante Informe que, el 25 de abril de 2005, presentó la Comisión creada para el estudio y preparación del Estatuto Básico del Empleado Público. Su calidad técnica y su exposición de la situación actual de la Función Pública en España son dignas de encomio, sin perjuicio de que las opciones por las que se decanta puedan no recibir el mismo elogio. Sea como fuere, las propuestas que planteaba el Informe presentaban una coherencia interna que en algunos casos se ha perdido en la tramitación parlamentaria del Proyecto de Ley.

Lo primero que llama la atención de la Ley 7/2007 es su título, que constituye toda una declaración de intenciones en sus tres elementos: «Estatuto», «Básico»y «Empleado Público».

\section{Estatuto}

Formalmente, la referencia a un "Estatuto» entronca directamente la Ley 7/2007 con el artículo 103.3 de la Constitución, según el cual «la ley regulará el estatuto de los funcionarios públicos». En realidad, dicho precepto utiliza la expresión en un sentido más bien sustantivo, pero lo realmente trascendente en el mismo es su finalidad, que no es otra que establecer una reserva de ley sobre lo que sea el «estatuto» de los funcionarios públicos, cuyo contenido especifica a continuación de manera no exhaustiva: «el acceso a la función pública de acuerdo con los principios de mérito y capacidad, las peculiaridades del ejercicio de su derecho a sindicación, el sistema de incompatibilidades y las garantías para la imparcialidad en el ejercicio de sus funciones».

El alcance de esta reserva de ley del artículo 103.3 de la CE fue frontal-

1 BOE núm. 89, de 13 de abril. En adelante, EBEP.

2 SSTC 37/2002, de 14 de febrero, y $1 / 2003$, de 16 de enero. 
mente abordado en la célebre Sentencia del Tribunal Constitucional 99/ 1987, de 11 de junio. En ella, el Tribunal recordó que «en el artículo 103.3 de la Constitución se establece, efectivamente, una reserva para la regulación por Ley de diversos ámbitos de la Función Pública, entre los que se cuenta el "Estatuto de los funcionarios públicos" » [FJ. 3.a)], procediendo, a continuación, a establecer la interpretación de esa locución que, por su trascendencia, es preciso reproducir, pues, según la configuración de desarrollo aplicativo previsto por el EBEP, no sólo va a determinar lo que las Leyes de Función Pública (estatal y autonómicas) deben necesariamente incluir, sino que también establece el límite infranqueable tanto al reglamento como a la negociación colectiva. Conforme a dicha Sentencia, «la Constitución ha reservado a la Ley la regulación de la situación personal de los funcionarios públicos y de su relación de servicio o "régimen estatutario", por emplear la expresión que figura en el artículo 149.1.18 de la misma Norma fundamental. Es éste, desde luego, un ámbito cuyos contornos no pueden definirse en abstracto y a priori, pero en el que ha de entenderse comprendida, en principio, la normación relativa a la adquisición y pérdida de la condición de funcionario, a las condiciones de promoción en la carrera administrativa y a las situaciones que en ésta puedan darse, a los derechos y deberes y responsabilidad de los funcionarios y a su régimen disciplinario, así como a la creación e integración, en su caso, de Cuerpos y Escalas funcionariales y al modo de provisión de puestos de trabajo al servicio de las Administraciones Públicas, pues habiendo optado la Constitución por un régimen estatutario, con carácter general, para los servidores públicos (arts. 103.3 y 149.1.18), habrá de ser también la Ley la que determine en qué casos y con qué condiciones puedan reconocerse otras posibles vías para el acceso al servicio de la Administración Pública. Las normas que disciplinen estos ámbitos serán, en el concepto constitucional, ordenadoras del Estatuto de los funcionarios públicos, pues todas ellas interesarán directamente a las relaciones entre éstos y las Administraciones a las que sirven, configurando así el régimen jurídico en el que pueda nacer y desenvolverse la condición de funcionario y ordenando su posición propia en el seno de la Administración. Esta normación, en virtud de la reserva constitucional a la que se viene haciendo referencia, habrá de ser dispuesta por el legislador en términos tales que, de conformidad con lo antes observado, sea reconocible en la Ley misma una determinación material suficiente de los ámbitos así incluidos en el Estatuto funcionarial» [FJ 3.c) $]^{3}$.

Ahora bien, el objetivo y finalidad del nuevo EBEP no es establecer el «Estatuto» de los funcionarios públicos previsto en el artículo 103.3 de la Constitución, a guisa de cumplimiento de ese supuesto mandato constitucional que de él se derivaría y al que tanto se hace referencia (incluso en la Exposición de Motivos del EBEP), sino determinar la legislación básica del régimen jurídico de los funcionarios públicos. Y es que el artículo 103.3 CE

3 Doctrina reiterada posteriormente en SSTC 235/2000, de 5 de octubre, y 37/2002, de 14 de febrero. 
no es norma de atribución de competencias ${ }^{4}$, por lo que dicho «Estatuto» lo deberá establecer quien ostente competencias para ello. Y, a tal efecto, el artículo 149.1.18. ${ }^{\mathrm{a}}$ atribuye al Estado la aprobación de la legislación básica del régimen jurídico de los funcionarios, dejando a las Comunidades Autónomas (y al Estado, para su Administración) la competencia para dictar su propia legislación de Función Pública de conformidad con aquella legislación básica. Por tanto, el teórico «Estatuto» de los funcionarios viene integrado, en la práctica, por la legislación básica más cada legislación específica de Función Pública de cada Administración territorial (Estado y Comunidades Autónomas). En suma, el EBEP no es más que una parte de ese «Estatuto» previsto en el artículo 103.3 de la Constitución, pero su razón de ser no es la de establecer ese Estatuto. Desde esta perspectiva se explica y se entiende lo aparentemente truncado del régimen jurídico que establece, que en muchos aspectos ni siquiera es operativo, pues su aplicación va a requerir un primer desarrollo legislativo por el Estado y por las Comunidades Autónomas, en el ámbito de sus competencias.

\section{Estatuto «Básico»}

Como se ha expuesto anteriormente, el objetivo y finalidad del EBEP es "establecer las bases del régimen estatutario de los funcionarios públicos» (art. 1.1), para lo cual la Disposición Final Primera invoca expresamente el

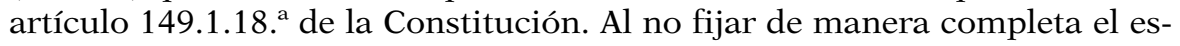
tatuto legal de los funcionarios, se obliga a un movimiento en cascada de los legisladores autonómicos, pero también del estatal ${ }^{5}$.

\subsection{Las bases del régimen estatutario de los funcionarios.}

Desde el punto de vista competencial, al Estado corresponde establecer "las bases del régimen jurídico de las Administraciones Públicas y del régimen estatutario de sus funcionarios» (art. 149.1.18. ${ }^{a} \mathrm{CE}$ ). De esta forma, la intención de la Constitución es que exista un régimen estatutario funcionarial que sea común a todas las Administraciones Públicas. Ahora bien, ese régimen común, al encauzarse a través de la técnica legislativa de las bases, obliga a dejar a las Comunidades Autónomas un margen propio para desplegar sus opciones particulares de configuración de su Función Pública.

Múltiples son los problemas que plantea siempre la utilización de la legislación básica y la Función Pública no ha sido un ámbito exento de ellos. Algunos hacen referencia a los instrumentos normativos en que puede apa-

4 R. Jiménez AsENSIO, «El reparto de competencias entre el Estado y las Comunidades Autónomas en materia de Función Pública», en RVAP, núm. 69 (1), 2004, págs. 140-142.

5 «Festival de leyes» lo ha calificado críticamente SosA WAGNER, en El Mundo, 24 de septiembre de 2007. 
recer definida la regulación básica del régimen estatutario de los funcionarios (noción formal de las bases) y otros al alcance o contenido de dicha regulación (noción material de las bases).

\subsubsection{La noción formal de las bases del régimen estatutario} de los funcionarios.

Desde el punto de vista formal, las bases del régimen estatutario de los funcionarios serán definidas por una norma con rango de ley, si bien cabe la posibilidad de la intervención excepcional del reglamento a la hora de desarrollar y completar aspectos que previamente han sido declarados básicos por una ley.

La definición de lo básico en materia de Función Pública fue acometida por la Ley 30/1984. No obstante, al ser ésta una Ley fragmentaria que no regulaba de forma exhaustiva la materia, permitió o, mejor dicho, obligó a recurrir a los preceptos que continuaban vigentes de la Ley de Funcionarios Civiles de 1964 para dibujar un mapa coherente de la normativa básica del régimen estatutario de los funcionarios. De lo contrario, algunos aspectos importantes relativos, por ejemplo, a la adquisición y pérdida de la relación funcionarial o a situaciones administrativas, que sólo parcial aunque trascendentalmente eran regulados por la Ley 30/1984, no tendrían carácter básico, privando de coherencia al «régimen estatutario básico». De esta manera, la legislación autonómica se veía obligada a deducir racionalmente aspectos básicos de la normativa preconstitucional de Función Pública (STC 5/1982, de 8 de febrero), inferencias que, en última instancia, eran controladas por el Tribunal Constitucional, que se veía igualmente impelido a calificar como básicos puntuales preceptos preconstitucionales objeto de litigio. Esta situación tenía la ventaja de que el intérprete supremo de la Constitución era el que definía, según la naturaleza y contenido de los preceptos, el alcance de lo básico, pero generaba demasiadas incertidumbres y se antojaba injustificada según pasaban los años desde la aprobación de la Constitución.

Finalmente, la STC 37/2002, de 14 de febrero, ha cortado de raíz la posibilidad de seguir deduciendo bases de la legislación anterior a la Constitución de 1978. Según aquélla, «la noción formal de bases elaborada por la doctrina de este Tribunal Constitucional y la finalidad con ella perseguida de dotar de una determinación cierta y estable a los ámbitos respectivos de ordenación de las materias en las que concurren y se articulan las competencias básicas estatales y las legislativas y reglamentarias autonómicas mal se compadecen con la posibilidad de poder seguir infiriendo bases de las normas legales preconstitucionales cuando el legislador estatal constitucional ha procedido en el ejercicio de la competencia constitucionalmente atribuida a establecer de manera aparentemente completa e innovadora las bases sobre una determinada materia, a menos que declare expresamente la pretendida naturaleza básica de esas normas legales preconstitucionales o 
dicha naturaleza resulte, sin lugar a dudas, de ser éstas un complemento indispensable de las normas básicas postconstitucionales por deducirse de su propia estructura que no han pretendido agotar la regulación de todos los aspectos de la materia».

No hay que confundir el hecho de que las bases del «régimen estatutario de los funcionarios» deban venir reguladas por una ley (art. 149.1.18. ${ }^{a} \mathrm{CE}$ ) con la reserva de ley a la que se encuentra sometido el «estatuto de los funcionarios públicos» (art. 103.3 CE), pues se trata de instituciones formal y sustantivamente diferentes, aunque parcialmente coincidentes en el caso del Estado.

\subsubsection{El contenido de las bases del régimen estatutario de los funcionarios.}

Más trascendente y compleja es la definición del concepto material de las bases del régimen estatutario de los funcionarios, pues de ella van a depender las competencias efectivas de las Comunidades Autónomas para legislar sobre su propia Función Pública.

Con carácter previo, es imprescindible adelantar una serie de consideraciones que permitirán aprehender la problemática. En primer lugar, la definición material de lo básico es una competencia exclusiva del legislador estatal, el cual goza de una completa libertad para establecer con carácter general las bases de una determinada materia, sin que la calificación hecha por aquél —expresión de una legítima política legislativa— pueda ser fiscalizada por el Tribunal Constitucional, pues éste no es juez de la oportunidad, si bien al establecer lo básico el Estado tiene que respetar la competencia legislativa propia de las Comunidades Autónomas sobre Función Pública, sin que la legislación básica agote la regulación del régimen estatutario y no deje margen de actuación al legislador autonómico. Como señaló el Tribunal Constitucional, «la definición de las bases, en el ámbito de la legislación compartida, tiene por objeto crear un marco normativo unitario, de aplicación a todo el territorio nacional, dentro del cual las Comunidades Autónomas dispongan de un margen de actuación que les permita, mediante la competencia de desarrollo legislativo, establecer los ordenamientos complementarios que satisfagan sus peculiares intereses; por ello, en principio, debe entenderse que excede de lo básico toda aquella ordenación que, por su minuciosidad y detalle, no deja espacio alguno a la competencia autonómica de desarrollo legislativo, produciéndose en tal caso, por regla general, un resultado de vulneración competencial que priva a lo presentado como básico de su condición de tal» (STC 147/1991, de 4 de julio).

Esto no implica que el alcance material de las bases se deba reducir al nivel de la mera abstracción, como principios genéricos que precisan ineludiblemente concreción legislativa posterior, pues las bases pueden asimismo articular la regulación de un aspecto si lo considera necesario el legislador estatal para asegurar un mínimo común normativo homogéneo de 
ámbito nacional. Esto lleva a tener que distinguir, al definir lo básico, tanto su extensión como su intensidad, pues una cosa es que una institución o aspecto sea objeto de regulación con carácter básico (por ejemplo, situaciones administrativas, provisión de puestos de trabajo, retribuciones, etc.) y otra muy distinta la intensidad de esa regulación, pues el legislador básico puede regular más o menos elementos.

De todo lo anteriormente dicho se entiende que el alcance de lo básico es en cada período coyuntural, pues se encuentra supeditado a la opción legislativa del Estado, que, discrecionalmente, puede otorgar una mayor o menor extensión e intensidad a lo que considere básico en un momento determinado. En esta operación de definir el alcance extensivo e intensivo de lo básico, el Tribunal Constitucional sólo ha limitado al legislador estatal desde la perspectiva del exceso, no del defecto. Es decir, que el Tribunal puede considerar que el legislador estatal se ha excedido, en extensión o en intensidad, a la hora de calificar como básico un aspecto concreto o singular. Pero, por el contrario, no puede reputar inconstitucional la omisión del legislador de calificar un aspecto determinado (en su extensión o en su intensidad) como básico, pues ello entraría dentro del legítimo margen de que dispone el legislador estatal a la hora de definir lo básico. El único límite, por tanto, será regular y definir en exceso lo básico, pues ello limita o elimina la competencia propia de las Comunidades Autónomas. De ahí que el control sea más factible desde el punto de vista intensivo que extensivo. Así, por ejemplo, el legislador básico puede establecer que los funcionarios se agruparán en Cuerpos, pero en lo que respecta a su concreta regulación y articulación, aquél, por un lado, no puede agotar las posibilidades de configuración para dejar margen a las Comunidades Autónomas y, por otro, tampoco debe limitarse a los principios o a unas bases abstractas y evanescentes, de manera que el legislador básico podría fijar que los funcionarios se agruparán en Cuerpos y, a continuación, extraer de ello más o menos configuración y articulación, siempre que deje —insistimos - un margen configurador propio a las Comunidades Autónomas.

$\mathrm{Al}$ hilo de este ejemplo, es necesario hacer una última consideración de la jurisprudencia constitucional relativa a que «la intensidad y extensión que pueden tener las bases no es la misma en todos los ámbitos que integran ese régimen jurídico. Así, el alcance de lo básico será menor en aquellas cuestiones que se refieren primordialmente a la organización y al funcionamiento interno de los órganos de las Administraciones Públicas, que en aquellas otras que inciden más directamente en su actividad externa, sobre todo cuando afectan a la esfera de derechos e intereses de los administrados, aunque ciertamente no cabe trazar una distinción tajante entre unos aspectos y otros. No debe olvidarse que, según establece el artículo 149.1.18 CE, el objetivo fundamental, aunque no único, de las bases en esta materia es el de garantizar y no cabe duda de que cuanto menor sea la posibilidad de incidencia externa de las cuestiones reguladas por los preceptos impugnados, más remota resultará la necesidad de asegurar ese tratamiento común y, por el contrario, mayor relieve y amplitud adquirirá la 
capacidad de las Comunidades Autónomas de organizar su propia Administración según sus preferencias» (STC 50/1999, de 6 de abril). Esta doctrina tendrá una gran influencia a la hora de definir la bases materiales del régimen estatutario de los funcionarios, en la medida en que los elementos estructurales de dicho régimen estatutario se encuentran intrínsecamente vinculados a la organización de las Administraciones Públicas, por lo que su intensidad de regulación básica será considerablemente más reducida.

Desde estas premisas, es necesario analizar el alcance o contenido material de las bases del régimen estatutario de los funcionarios públicos, según la Constitución. Para ello resulta imprescindible partir de la temprana Sentencia 76/1983, de 5 de agosto, donde el Tribunal Constitucional consideró que «el artículo 149.1.18. ${ }^{\text {a }}$ de la Constitución reconoce al Estado competencia exclusiva para dictar las bases del régimen jurídico de las Administraciones públicas y del régimen estatutario de sus funcionarios. De ello deriva una doble competencia estatal en materia de función pública: 1 a $^{\mathrm{a}}$ competencia para regular los aspectos básicos de la situación personal de los funcionarios públicos, es decir, de la denominada relación de servicio, contenido indiscutible del régimen estatutario, y 2. ${ }^{a}$ competencia para regular los aspectos esenciales de la organización de la burocracia de las Administraciones públicas, pues la expresión "régimen jurídico" contenida en el precepto constitucional no se refiere exclusivamente al procedimiento y al régimen de recursos, como ha señalado este Tribunal Constitucional en su Sentencia 32/1981, de 28 de julio, y ha de entenderse incluida también en ella la regulación básica de la organización de todas las Administraciones públicas».

Pues bien, en lo que atañe a la relación de servicio (en la medida en que determina la situación personal o posición subjetiva del funcionario), la jurisprudencia constitucional ha permitido una regulación más agotadora de las bases: adquisición y pérdida de la relación; situaciones administrativas; derechos y obligaciones; incompatibilidades; órganos y procedimientos de participación de funcionarios en la determinación de las condiciones de trabajo. En cambio, la relación orgánica, en la medida en que afecta a aspectos esenciales de la organización de la burocracia de las Administraciones Públicas, no tiene por qué ser un aspecto básico ${ }^{6}$. En un primer momento, la legislación postconstitucional apenas si reflejó esa posible diferencia de intensidad en la regulación de lo básico, lo que, unido al proceso de inferencia natural sobre la legislación preconstitucional, dibujaba un escenario en el que el margen de maniobra de las Comunidades Autónomas era reducido ${ }^{7}$. En este punto, precisamente, se observa un cambio de concepción en el EBEP.

\footnotetext{
6 Por ejemplo, las agrupaciones funcionariales (STC 54/1982, de 26 de julio).

7 G. FERNÁNDEZ FARRERES, «Régimen jurídico de la Función Pública y Jurisprudencia constitucional», en Revista del Centro de Estudios Constitucionales, núm. 12, mayo-agosto 1992, pág. 65. En el mismo sentido, A. Palomar Olmeda, Derecho de la Función Pública, Dykinson, Madrid, 2003, pág. 225.
} 


\subsection{El Estatuto Básico del Empleado Público en cuanto bases} del régimen estatutario de los funcionarios.

\subsubsection{La reducción de la densidad de la legislación básica.}

En un contexto generalizado de opción de política legislativa caracterizado por lo que se ha dado en llamar un «adelgazamiento» de lo básico, el EBEP refleja como pocas normas esta elección por una reducción de la densidad de la legislación básica en materia de Función Pública. La Exposición de Motivos envuelve este fenómeno en dos motivos: uno político y otro técnico. El primero, la profunda descentralización político-administrativa experimentada en España con la creación y consolidación de las Comunidades Autónomas, y la consecuente implantación de Administraciones Públicas con Funciones Públicas propias, de donde se deriva la exigencia de que cada Administración pueda configurar su propia política de personal y su particular modelo de Función Pública. El segundo motivo, de carácter aparentemente técnico, sería el de permitir regulaciones sectoriales diferenciadas de acuerdo con la diversidad de formas de gestión de servicios y actividades públicos.

El Informe de la Comisión señaló las siguientes finalidades que debería perseguir la legislación básica en materia de Función Pública ${ }^{8}$ : reafirmar los principios constitucionales sobre el empleo público; garantizar la igualdad básica de los derechos y deberes de los empleados públicos de todas las Administraciones; facultar al Estado para ejercer sus competencias sobre política económica general y estabilidad presupuestaria9; regular las relaciones de servicio y laborales en el empleo público; y «facilitar la interconexión o comunicación de los sistemas de empleo público de los diferentes niveles de administración y la coordinación voluntaria de sus políticas de empleo». Con estas finalidades, en realidad, podría caber cualquier cosa y el elenco de materias que realizaba a continuación extendía el alcance del Estatuto Básico sobre todas las instituciones y técnicas propias de la Función Pública $^{10}$. La clave no radicaba, en cambio, en la amplia extensión de la le-

8 Informe de la Comisión para el estudio y preparación del Estatuto Básico del Empleado Público, 25 abril 2005, n. 13.

9 La Disposición Final Primera, relativa a la habilitación competencial del EBEP, invoca expresamente el artículo 149.1.13. a de la Constitución, que se refiere a las bases y coordinación de la planificación general de la actividad económica.

10 Los principios ordenadores del empleo público; la determinación y definición de las clases de empleados públicos, incluido el personal directivo, especificando el tipo de legislación aplicable a las relaciones de empleo en cada caso; los instrumentos de planificación, ordenación y gestión de los recursos humanos, con la flexibilidad necesaria para que cada Administración adopte los que más le convengan; los requisitos generales para el acceso al empleo público y los elementos que garanticen la efectividad de los principios de mérito y capacidad e igualdad, así como la transparencia y la agilidad de los procesos selectivos; los aspectos y garantías básicos de promoción profesional, sobre la base de los criterios de mérito y capacidad y de rendimiento y en atención a las necesidades del servicio; las normas básicas sobre situaciones administrativas y extinción de la relación de servicio de los em- 
gislación básica, sino en su escasa intensidad, a cuyos efectos se mentaban los principios de subsidiariedad y de proporcionalidad.

Es, pues, en este juicio de proporcionalidad sobre la legislación básica donde se recupera, de entrada, la distinción fundamental entre relación de servicio y relación orgánica. En efecto, partiendo de la consideración radical de la Función Pública como elemento vinculado a la organización administrativa, por un lado, y de la potestad de autoorganización de las Administraciones Públicas (en particular, de las Comunidades Autónomas), por otro, se remite a éstas la definición y configuración de la estructura objetiva de la Función Pública. Así, la «estructuración del empleo público» (capítulo II del título V) apenas si aparece dotada de contenido en el EBEP, salvo lo relativo a los grupos de clasificación dependientes de las titulaciones educativas. Pero en todo lo referente a las agrupaciones de puestos o de funcionarios se estará a lo establecido por el modelo concreto de cada Ley de Función Pública. En cambio, en lo tocante al contenido estricto de la relación de servicio (derechos y obligaciones), el EBEP lleva a cabo una intensificación apreciable de lo básico.

El resultado final es una Ley que presenta una densidad básica internamente desequilibrada entre el «estatuto objetivo» (la estructura) de la Función Pública y el «estatuto subjetivo» (derechos y obligaciones) de los funcionarios. Paradójicamente, tan criticable puede resultar la reducción del primero como la amplitud del segundo. En relación con la merma en la intensidad de lo básico, se ha cuestionado tanto su oportunidad política o administrativa como — con menos fundamento - su viabilidad constitucional $^{11}$. Por su parte, los derechos de los funcionarios públicos aparecen regulados en ocasiones con previsiones tan detalladas y concretas que sorprenden en un contexto general de reducción de lo básico. Tal es el caso de los derechos a la negociación colectiva y a la representación y participación institucionales, donde además concurre una vinculación estrecha a la organización administrativa. O las previsiones sobre permisos de los funcionarios, donde, por añadidura, el EBEP introduce una peculiar dádiva de difícil justificación desde lo básico, como son los dos días adicionales de libre disposición que disfrutarán los funcionarios al cumplir el sexto trienio, in-

pleados públicos; las normas básicas que faciliten la movilidad de los empleados entre las distintas Administraciones Públicas; los supuestos y causas de extinción de las relaciones de empleo público; el conjunto de derechos básicos de los empleados públicos; las bases del régimen retributivo de los funcionarios públicos; el sistema de representación y la estructura, contenido y efectos de la negociación colectiva de los funcionarios públicos y otros procedimientos de participación y de solución de conflictos y las reglas especiales aplicables al personal laboral; los principios éticos y deberes básicos de los empleados públicos; las normas básicas sobre incompatibilidades de los empleados públicos; los principios del régimen disciplinario; las relaciones de cooperación entre las Administraciones en materia de empleo público. Informe de la Comisión para el estudio y preparación del Estatuto Básico del Empleado Público, 25 abril 2005, n. 13.

11 J. FonDEVILA, «Reflexiones en torno al informe para la preparación de un Estatuto Básico de Empleado Público: especial referencia a la propuesta de reducción del contenido y alcance de lo básico», en Revista de Estudios de la Administración Local y Autonómica, núms. 298-299, mayo-diciembre 2005, págs. 169-225. 
crementándose en un día adicional por cada trienio cumplido a partir del octavo (art. 48.2 EBEP).

\subsubsection{Peculiaridades en el uso de la técnica básica del EBEP.}

Uno de los aspectos más destacables del EBEP son algunas peculiaridades que presenta una legislación que se dicta como básica y que, por tanto, debería establecer ese mínimo común normativo en todo el territorio nacional.

En primer lugar, el EBEP contiene previsiones que realmente no fijan un mínimo común, sino que dejan a las Comunidades Autónomas y al Estado la opción de aceptar o no, a través de su normativa propia, instituciones o elementos enteros de la Función Pública. Es el caso, por ejemplo, de una de sus innovaciones más destacadas, como es el personal directivo (art. 13), «llamado a constituir en el futuro un factor decisivo de modernización administrativa», según la Exposición de Motivos. Pues bien, la implantación efectiva y el desarrollo normativo ${ }^{12}$ de esta figura se dejan a la voluntad de los gobiernos de las Administraciones Públicas (Estado y Comunidades Autónomas), por lo que en última instancia podría darse el caso de un modelo de Función Pública que prescindiera de esta figura.

Pero el supuesto de previsión básica facultativa más llamativo es, sin duda alguna, el relativo a las modalidades de carrera que el EBEP establece. Según el artículo 16.3, las Leyes de Función Pública que desarrollen el EBEP regularán la carrera profesional de su ámbito respectivo, «que podrán consistir, entre otras, en la aplicación aislada o simultánea de alguna o algunas» de las modalidades que prevé el Estatuto Básico: carrera y promoción interna, vertical u horizontal en ambos casos. Pues bien, si el Proyecto de Ley ya ofrecía aquí un menú dispositivo - pero limitado- de modalidades de carrera (alguna o algunas de las cuatro), la tramitación parlamentaria ha introducido ese perturbador «entre otras» que viene a dejar libertad absoluta para que cada Ley de Función Pública implante la modalidad de carrera que estime oportuno, sin verse siquiera limitada por las cuatro modalidades previstas en el EBEP.

En otras ocasiones, el EBEP se limita a habilitar o autorizar que las Administraciones Públicas organicen la gestión de su empleo público conforme a determinadas posibilidades igualmente opcionales. Así, se permite a las Administraciones Públicas la delegación de actividades de negociación colectiva a órganos técnicos especializados, que las representarán en las mesas de negociación, que actuarán conforme a sus instrucciones políticas y cuyos acuerdos precisarán la ratificación del órgano competente según los casos (art. 33.3 EBEP). Otro ejemplo es el de los órganos especializados y permanentes de selección de personal, cuya posibilidad se prevé en el artículo 61.4 EBEP. Como se ve, el EBEP se limita a autorizar estas formas de gestión (de la negociación colectiva o de la selección de empleados), el re-

12 Deslegalización que no estaba prevista originariamente en el Proyecto de Ley. 
curso a las cuales dependerá de la potestad de autoorganización de cada Administración Pública. Por lo que, en última instancia, cabe plantearse lo superfluo o innecesario de su previsión en el EBEP, pues aunque no estuviese recogida esa habilitación en el Estatuto Básico bien podría cada Administración organizar la gestión de sus recursos humanos conforme considere oportuno. De hecho, la creación de órganos especializados de gestión se puede extender a otros aspectos de los recursos humanos que no tienen por qué estar autorizados expresamente en el EBEP.

Pero el supuesto más peculiar es la utilización de la legislación básica con una eficacia supletoria. Es el caso del artículo 48.1 del EBEP, relativo a los permisos de los funcionarios. Según el mismo, las Administraciones Públicas determinarán los supuestos de concesión de permisos a los funcionarios públicos y sus requisitos, efectos y duración. Ahora bien, "en defecto de legislación aplicable» de esas Administraciones Públicas, «los permisos y su duración serán, al menos», los que aparecen en dicho precepto. Independientemente de la ambigüedad sobre si los permisos deben ser regulados por reglamento (en virtud del llamamiento a las «Administraciones Públicas») o por ley (utilización de la expresión «legislación aplicable»), lo destacable es que la regulación completa y exhaustiva que hace el EBEP sobre los permisos de los funcionarios no constituye un mínimo común normativo para todo el territorio nacional porque sean las bases que informen la legislación de Función Pública de Estado y Comunidades Autónomas, sino que se configura, primero, como normativa supletoria que sólo regirá «en defecto de legislación aplicable» $\mathrm{y}$, segundo, como normativa superable por la normativa o por el convenio colectivo. Cada Ley podrá o no regular los permisos de los funcionarios. Si no lo hace, se aplicará supletoriamente la legislación básica. Si lo hace, deberá respetar el mínimo previsto en la legislación básica, pero es libre de introducir mejoras al alza.

Éstas son, en suma, las peculiaridades que presenta el EBEP a la hora de establecer la legislación básica de los funcionarios públicos. Lo básico como facultativo o disponible, lo básico como habilitación o autorización y lo básico como supletorio resultan, en última instancia, intrínsecamente contradictorios con la finalidad y concepto mismo de la legislación básica como norma que establece una regulación mínima y común, necesaria e indispensable, segura e indisponible.

\subsection{Las bases del régimen estatutario de los funcionarios fuera del EBEP.}

Al igual que el EBEP no es todo el «Estatuto» de los funcionarios públicos del artículo 103.3 CE, aquél tampoco es toda la legislación básica del régimen estatutario de los funcionarios. Y es que ha quedado fuera del EBEP la legislación básica sobre incompatibilidades (recogida en la Ley 53/1984, de 26 de diciembre), en contra de la propuesta del Informe del Comité de Expertos, que acertadamente abogaba por su inclusión y su universaliza- 
ción —en aras de la igualdad, transparencia y seguridad jurídica- a todo el personal al servicio de las Administraciones Públicas, también el regulado por leyes especiales u orgánicas (Administración de Justicia, Consejo de Estado, Tribunal Constitucional, etc.).

\subsection{El contenido no básico del EBEP.}

Pero el Estatuto Básico del Empleado Público no es sólo legislación básica del régimen jurídico de los funcionarios. Tal y como especifica su artículo 1.2, también tiene por objeto «determinar las normas aplicables al personal laboral al servicio de las Administraciones Públicas», dictadas, según la Disposición Final Primera EBEP, al amparo del artículo 149.1.7. a de la Constitución, que otorga al Estado competencia exclusiva sobre la legislación laboral. No es, pues, legislación básica, sino legislación directamente aplicable que tan sólo puede ser «ejecutada» por las Comunidades Autónomas. De esta forma, mientras en relación con el régimen estatutario de los funcionarios públicos las Comunidades Autónomas pueden aprobar legislación propia en el marco de las bases estatales, la relación laboral en el ámbito de las Administraciones Públicas es uniforme en toda España, sin perjuicio de la eventual adaptación normativa de esta relación laboral a la organización administrativa que algunos Estatutos de Autonomía han reconocido a sus Comunidades Autónomas - v.gr., arts. 76.2.c) EA Andalucía o 136.c) EA Cataluña-.

\section{Estatuto Básico del «Empleado Público»}

Así pues, el Estatuto es, por un lado, legislación básica del régimen jurídico de los funcionarios públicos y, por otro, legislación de la relación laboral de empleo público. Todo ello cubierto a la par por la expresión «empleado público». Es, sin duda alguna, el gran hallazgo terminológico de la Ley $7 / 2007$. Una suerte de síntesis superadora de la histórica dialéctica entre la tesis funcionarial y la antítesis laboral. En realidad, no hay tal síntesis, pues la locución «empleado público» es una noción formal carente de contenido propio. No es ni una clase ni una categoría de personal al servicio de las Administraciones Públicas. Es un recurso nominal para referirse al mismo tiempo a dos realidades diferentes: funcionarios y contratados laborales. En suma, una técnica legislativa.

Pero, más allá de esta perspectiva de técnica legislativa, el porqué de esta expresión se encuentra en el hecho de que aúne asépticamente (esto es, sin prejuzgar la naturaleza jurídica del vínculo) a todo el personal (de ahí que se hable de "empleado») al servicio de las Administraciones Públicas (de ahí, obviamente, el término "público»). Y, en última instancia, responde a la idea de la convergencia de regímenes jurídicos de funcionarios y laborales, sometidos a las mismas reglas jurídicas. La expresión no es, pues, neutral, ya que de otra manera habrían bastado locuciones ya utilizadas como las de «agentes públicos» o «personal al servicio de las Administraciones Públicas». 


\section{Estatuto BÁsico y Comunidades Autónomas}

\section{Legislación básica y legislación autonómica}

«En desarrollo de este Estatuto, [...] las Asambleas Legislativas de las Comunidades Autónomas aprobarán, en el ámbito de sus competencias, las Leyes reguladoras de la Función Pública [...] de las Comunidades Autónomas» (art. 6 EBEP). De esta manera, la legislación autonómica de Función Pública se califica expresamente como desarrollo de la legislación básica. A pesar de ello, no hay que olvidar que se trata de una competencia legislativa propia ${ }^{13}$ en virtud de la cual las Comunidades Autónomas deben disponer de la suficiente capacidad de configuración para diseñar un modelo propio de Función Pública. De ahí que la intensidad de lo básico sea limitada, para dejar ese margen a las Comunidades Autónomas ${ }^{14}$, lo que en el caso de la Función Pública viene acentuado por su conexión con la potestad de autoorganización de aquéllas.

En efecto, para el Tribunal Constitucional, la organización de su propia Función Pública por una Comunidad Autónoma es, en sí mismo, un «bien constitucionalmente protegible». En la medida en que las Comunidades Autónomas se erigen en entidades políticas descentralizadas dotadas de autonomía, una de sus manifestaciones sería la de crear una Función Pública propia, expresión de su competencia de autoorganización. De ella se deriva una mayor capacidad a la hora de consolidar, modificar o completar sus estructuras y de configurar o concretar organizativamente el estatus del personal a su servicio. Más aún, el principio de autoorganización de las Comunidades Autónomas tendría un respaldo constitucional expreso [arts. 147.2.c) y, especialmente, 148.1.1 CE], plasmado normalmente en cada Estatuto de Autonomía, lo que supone el reconocimiento de la competencia autonómica para organizar no sólo su propia Administración Pública, sino también su propia Función Pública ${ }^{15}$.

Así pues, y como consecuencia de la opción política del legislador básico de reducir su extensión y su intensidad, las Comunidades Autónomas disponen de un amplio margen de configuración de su Función Pública, especialmente en su estructura objetiva, de la que depende decisivamente lo que se da en llamar el modelo de Función Pública. De hecho, hasta que no se aprueben estas Leyes autonómicas de Función Pública, todos los elemen-

13 Aunque sea propia, la competencia que tienen las Comunidades Autónomas para regular la organización de su burocracia (en su vertiente tanto de relación de servicio como de relación orgánica) no se reconduce a sus «instituciones de autogobierno», sino a la competencia específica relativa a la organización de sus propias Administraciones. De esta manera, al insertar la Función Pública en el adecuado nivel administrativo (art. 148.1.1. ${ }^{\mathrm{a}} \mathrm{CE}$ ) y no en el político (152.1 CE), puede el Tribunal Constitucional afirmar la aplicación de las bases estatales sobre Función Pública del 149.1.18. ${ }^{\mathrm{a}}$ a las Funciones Públicas autonómicas: STC 76/1983, de 5 de agosto.

14 STC 172/1996, de 31 de octubre, FJ 3.

15 SSTC 57/1990, de 29 de marzo; 293/1993, de 18 de octubre; 9/1995, de 16 de enero. 
tos del EBEP dependientes de esa estructura objetiva (ordenación, carrera, retribuciones, etc.) no podrán ser aplicados.

\section{Legislación básica y Estatutos de Autonomía}

Premisa, no obstante, de esa articulación constitucional legislación básica-legislación autonómica es la asunción competencial de la materia por las Comunidades Autónomas y las posibles contradicciones entre los Estatutos de Autonomía (y la legislación que amparen) y la legislación básica.

Esta cuestión es sumamente compleja y, evidentemente, no se ha circunscrito al debate académico, saltando a la palestra política. Con carácter general, la relación entre la legislación básica y los Estatutos de Autonomía se encuentra en la actualidad sub iudice al haberse frontalmente planteado en algunos recursos de inconstitucionalidad contra recientes Estatutos de Autonomía.

Más concretamente, la misma tramitación parlamentaria del EBEP propició precisamente la escenificación política de esta polémica relación. En efecto, partidos nacionalistas e independentistas catalanes acusaron al proyecto de EBEP de invadir las competencias que la Generalidad de Cataluña había asumido con su nuevo Estatuto de 2006. El resultado fue la Disposición Final Segunda, según la cual «las previsiones de esta Ley son de aplicación a todas las Comunidades Autónomas respetando en todo caso las posiciones singulares en materia de sistema institucional y las competencias exclusivas y compartidas en materia de función pública y de autoorganización que les atribuyen los respectivos Estatutos de Autonomía, en el marco de la Constitución». Como equilibrio político, su redacción es prodigiosa. Constitucionalmente, en cambio, esta Disposición no puede prejuzgar en abstracto la relación entre la legislación básica y los Estatutos de Autonomía.

Para SánChez MoRón, esta Disposición «es sorprendente y de escaso o nulo valor» ${ }^{16}$. Según este autor, la legislación básica del régimen estatutario de los funcionarios ex artículo 149.1.18. ${ }^{a}$ de la Constitución, que el EBEP establece, «no puede contradecir lo establecido en un Estatuto de Autonomía ni menoscabar las competencias autonómicas de cualquier clase reconocidas por él. De lo contrario, el EBEP sería, en el aspecto de que se trate, inconstitucional. Pero esta declaración y, por tanto, el contraste de la legislación básica con los Estatutos de Autonomía, corresponde hacerla solo al Tribunal Constitucional. Ahora bien, si el EBEP no es inconstitucional - y así hay que presumirlo, mientras no se declare lo contrario-, está respetando por definición todos los Estatutos de Autonomía y por tanto, todas las llamadas "posiciones singulares" y todas las competencias exclusivas y compartidas de todas

16 M. SÁNChez Morón, "Objeto y ámbito de aplicación», en Comentarios a la Ley del Estatuto Básico del Empleado Público (Dir. M. SÁnchez Morón), Lex Nova, Valladolid, 2007, pág. 65. 
las Comunidades Autónomas, en materia de función pública y en cualquier otra. Y, en tal caso, el EBEP debe ser aplicado en todas y por todas las Comunidades Autónomas por igual, en sus estrictos términos, sin ningún tipo de reserva, matiz o cortapisa. De donde se sigue que la disposición adicional segunda es absolutamente superflua en términos de Derecho» ${ }^{17}$.

Sin embargo, el EBEP no está solventando la problemática abstracta de la relación constitucional entre la legislación básica y los Estatutos de Autonomía, que, en cualquier caso, no se dilucidaría en clave de validez, sino de eficacia del Estatuto o de la legislación básica ${ }^{18}$. En virtud de los Estatutos de Autonomía, las Comunidades Autónomas asumen competencias. Independientemente de la calificación unilateral estatutaria como exclusiva o compartida, la controversia radica en si, en cualquier caso, la legislación básica informa el ejercicio de esas competencias o si la inclusión de una competencia exclusiva en un Estatuto de Autonomía supone la ineficacia de la legislación básica estatal, en ese ámbito territorial, en caso de concurrencia entre las bases y el Estatuto (y la normativa dictada al amparo de éste). La cuestión no es meramente teórica. Por ejemplo, el artículo 150 del nuevo Estatuto de Cataluña atribuye a esta Comunidad Autónoma la competencia exclusiva sobre la regulación de los directivos públicos. Al haber incluido el legislador estatal en el EBEP con carácter básico un régimen mínimo sobre el personal directivo, cabría cuestionarse si la regulación del Estatuto básico debe ser respetada por la regulación autonómica que se dicte en el ejercicio de esa competencia "exclusiva» prevista en el Estatuto de Cataluña ${ }^{19}$.

No obstante lo dicho, lo que estaría haciendo en realidad esta Disposición Final Segunda sería autolimitar el propio ámbito de aplicación del Estatuto Básico del Empleado Público en virtud de las competencias asumi-

17 Ibidem. Concluye este autor: «¿A qué viene entonces una regla como la de la citada disposición adicional? Sin duda sólo se entiende como una cláusula de exclusivo significado político, destinada a dar satisfacción moral o formal o a vencer las resistencias al pacto de algún o algunos grupos minoritarios de la Cámara. Un ejemplo más de la prioridad que en la tramitación gubernativa y legislativa del Estatuto se ha dado a la búsqueda del consenso político por encima de otras consideraciones».

18 En este sentido, F. Velasco, "Reforma de los Estatutos de Autonomía y reforma de las bases del régimen local», en Reforma y retos de la Administración Local (Dirs. R. PARADA y J. A. Fuentetaja), Marcial Pons, Madrid, 2007, pág. 144, quien se decanta por la inaplicación de la normativa estatal básica.

19 No es éste el único punto de potencial colisión entre el EBEP y el Estatuto de Cataluña de 2006. En efecto, el Estatuto de Autonomía de Cataluña de 2006, al definir las competencias compartidas de esa Comunidad Autónoma en su artículo 111, señala que las bases que fije el Estado en una materia se deben limitar a «principios» o a un «mínimo común normativo». La aplicación de esta concepción de lo básico a la Función Pública indica que Cataluña asume «la competencia compartida para el desarrollo de los principios ordenadores del empleo público, sobre la adquisición y pérdida de la condición de funcionario, las situaciones administrativas y los derechos, deberes e incompatibilidades del personal al servicio de las Administraciones públicas» [art. 136.1.b) EAC]. Parece señalarse que lo básico, respecto a esta Comunidad Autónoma, se circunscribiría a los principios ordenadores de la adquisición y pérdida de la condición de funcionario, de las situaciones administrativos y de los derechos, deberes e incompatibilidades. El resto es competencia exclusiva de la Comunidad Autónoma, cuya normativa no se vería informada por lo básico, por mucho que la legislación básica del Estado se extienda a más ámbitos de la Función Pública. 
das por las Comunidades Autónomas a través de sus Estatutos en materia de Función Pública. Es decir, el EBEP excepciona su aplicación en aquellas Comunidades Autónomas que hubieren asumido competencias exclusivas y compartidas en materia de Función Pública, con lo que primaría el Derecho autonómico sobre el Derecho estatal básico en aquellos extremos que éste fuera contrario a aquél. Cabría preguntarse si la legislación básica puede hacer tal cosa. En realidad, la respuesta nos la da el propio EBEP, pues esa Disposición Final Segunda, en última instancia, no es sino una generalización de excepciones puntuales también previstas en el propio EBEP. En efecto, la Disposición Adicional Tercera regula la aplicación del EBEP a las Instituciones Forales de Navarra y el País Vasco, que deberá hacer respetando, respectivamente, la Ley Orgánica 13/1982, de 10 de agosto, de Reintegración y Amejoramiento del Régimen Foral de Navarra, y la Ley Orgánica 3/1979, de 18 de diciembre, por la que se aprueba el Estatuto de Autonomía para el País Vasco.

\section{Estatuto BÁSico y LEGISLAción DEL Estado}

\section{Legislación estatal de Función Pública como desarrollo del EBEP}

Además de la legislación autonómica de Función Pública dictada en desarrollo de la legislación básica del Estatuto, el artículo 6 del EBEP concibe la legislación estatal de Función Pública como «desarrollo» de la legislación básica de Función Pública.

El artículo 6 EBEP tiene que remitirse a legislación estatal específica para la Administración General del Estado porque el EBEP — siendo legislación del Estado - no agota para aquella Administración la reserva de ley del artículo 103.3 CE. Y es que el objetivo del EBEP es establecer una norma básicamente pura del régimen estatutario de los funcionarios públicos. Ello obliga a una innovación en la técnica legislativa. Cuando tenía que dictar la legislación que le era aplicable, lo normal hasta ahora era que el Estado procediera en un solo texto a regulaciones completas y tendencialmente exhaustivas de una materia cuando tuviera competencia para ello, identificando simplemente los preceptos de esa ley que tuvieran carácter básico. Al estar incluidos en el mismo instrumento normativo, la relación entre lo legislativamente básico y lo legislativamente estatal strictu sensu se reducía a eventuales contradicciones internas. Con esta Ley del EBEP, en cambio, el legislador ha pretendido que la Ley básica redujera su contenido precisamente a lo básico, sin "contaminaciones» de preceptos que no tengan ese carácter. Esto hace que el Estado regule una materia, primero, con la legislación básica y, segundo, con la legislación estatal sobre la materia que no es básica y que puede dictar porque tiene competencia para ello, sin tener que limitarse constitucionalmente a lo básico. Se trata, insistimos, de dos textos normativos. Cuestión diferente es que la legislación estatal que regula la materia deba respetar lo establecido en la legislación básica. 
En efecto, del artículo 6 EBEP, que llama a una legislación estatal de «desarrollo»para el Estado, implícitamente se entiende la obligación por aquella legislación estatal de respetar la legislación básica, por entender que ésta se encuentra en una posición ordinamental superior. En consecuencia, si la legislación estatal de Función Pública vulnerase la legislación básica, sería inconstitucional. Sin embargo, el carácter básico de una ley estatal es exclusivamente relativo respecto a las Comunidades Autónomas. No existen leyes básicas frente al Estado, por lo que la legislación básica no es parámetro de control de la constitucionalidad de las leyes estatales.

Que la legislación básica no es canon de constitucionalidad de las leyes del Estado lo ha pretendido zanjar el Tribunal Constitucional en su Sentencia 240/2006, de 20 de julio. Dictada en el marco de la autonomía local, en dicha Sentencia viene a establecer que "a pesar de reconocer puntualmente "la singular y específica naturaleza y posición [de la Ley de las bases del régimen local] en el Ordenamiento jurídico" (STC 259/1988, de 22 de diciembre, FJ 2), de la jurisprudencia examinada no se concluye que la Ley reguladora de las bases del régimen local constituya siempre canon de validez de la ley, estatal o autonómica, a la hora de enjuiciar normas que desarrollen aspectos concretos de la autonomía local. De la ley estatal no lo constituye porque la Ley de las bases del régimen local, más allá de la referida naturaleza singular, y de su carácter básico ex artículo 149.1.18 CE, no ocupa en nuestro Ordenamiento una posición distinta a las demás leyes ordinarias del Estado, que pueden por tanto establecer disposiciones contrarias a la Ley de las bases del régimen local, las cuales deberán ser consideradas modificaciones legislativas pero no leyes inconstituciónales». Y concluye que "no puede pretenderse de este Tribunal que enjuicie una norma estatal utilizando como parámetro otra norma estatal [...] pues, lógicamente, si no se ha vulnerado la Constitución debe interpretarse como una nueva opción del legislador» (FJ 8).

Como consecuencia de todo lo anterior, el legislador estatal de Función Pública no tendría por qué respetar el EBEP. Podría no sólo dictar una Ley de Función Pública del Estado opuesta (total, parcial o puntualmente) al EBEP, sino también incidir sobre lo básico, explícita o implícitamente. Esto es, el legislador estatal, al dictar su Ley de Función Pública para la AGE, tiene varias posibilidades: en primer lugar, respetar in toto el EBEP; en segundo lugar, contradecir al EBEP, bien declarando explícitamente que lo básico tiene una nueva redacción (más o menos amplia, según la opción del legislador básico), bien reformando implícitamente incluso el EBEP, pues la ley posterior deroga a la anterior, aunque las exigencias formales de la legislación básica precisarían una manifestación explícita.

En tercer lugar, se podría dar incluso la situación teórica -y más discutible- de que el legislador estatal dictara una legislación de Función Pública incompatible con el Estatuto Básico, pero que al no decir que es una derogación o reforma expresa de la legislación básica, ésta subsistiera a efectos básicos respecto a las Comunidades Autónomas pero fuera inaplicada por el Estado, que no se vería vinculado por lo básico. Y todo ello sobre la base de que el ámbito de aplicación de esta legislación de desarrollo sería 
diferente al de la legislación básica del Estatuto Básico, pues se circunscribiría a la Administración General del Estado.

\section{Legislación estatal de Función Pública como normativa supletoria}

De lo que no cabe duda alguna es que la legislación estatal no básica de Función Pública tendrá una eficacia supletoria respecto a la legislación autonómica, pues el Estado ostenta competencia para dictar aquella legislación no básica para su Administración. No obstante, esta virtualidad supletoria no será fácilmente aplicable en la medida en que los sistemas autonómicos de Función Pública, por un lado, tendrán una clara vocación de exhaustividad y, por otro, serán cada vez más heterogéneos entre sí y frente al modelo estatal de Función Pública, del que se apartarán cada vez más, en especial en lo relativo a la estructura objetiva, donde la normativa básica se ha reducido considerablemente.

\section{Estatuto BÁsico Y NEGOCIACIÓN COLECTIVA ${ }^{20}$}

Junto a las Leyes del Estado o de las Comunidades Autónomas que se deben dictar como «desarrollo» del EBEP, otra pieza fundamental para su aplicación son los Pactos y Acuerdos en que desemboca la negociación colectiva entre los empleados públicos y las Administraciones Públicas. En este ámbito, el EBEP realiza una opción trascendental por la eficacia normativa de tales instrumentos, erigiéndolos como peculiares fuentes reguladoras de las condiciones de empleo de los funcionarios.

Aunque contemplada conjuntamente como un derecho de los empleados públicos, la negociación colectiva de laborales y funcionarios es radicalmente disímil. Tan es así que no sólo el EBEP se remite para los primeros al Estatuto de los Trabajadores (art. 32), sino que es precisamente esta negociación colectiva laboral y los convenios colectivos en que se plasma la prueba más evidente de la artificiosa unificación del régimen de laborales y funcionarios intentada por el EBEP. Y es que éste — para aquélloses norma mínima a desarrollar o complementar vía convenios colectivos, permitiéndose a través de éstos continuas especificaciones y singularidades de régimen jurídico que escapen a la normativa inicialmente común (v.gr., retribuciones, provisión, movilidad o disciplina), a no ser que se califique esa legislación laboral del Estatuto Básico como «Derecho necesario» indisponible por negociación colectiva laboral ${ }^{21}$. Para el personal funcionario, en cambio, el EBEP (y sus leyes de desarrollo) constituyen el

20 Vid. R. Roqueta Buj, El derecho de negociación colectiva en el Estatuto Básico del Empleado Público, La Ley, Madrid, 2007.

21 Así lo hizo la Comisión Permanente de la Comisión Superior de Personal en su Acuerdo de 20 de abril de 2007 sobre el permiso de paternidad y la suspensión del contrato de trabajo por paternidad. 
marco dentro del cual debe desenvolverse esta negociación colectiva administrativa.

\section{Contenido de la negociación colectiva funcionarial}

El contenido de las materias sometidas a negociación colectiva se delimita positiva y negativamente. Desde esta última perspectiva, el EBEP (art. 37.2) señala, en primer lugar, la obvia exclusión de las decisiones de las Administraciones Públicas que afecten a su potestad de autoorganización, si bien introduce a continuación una excepción llamada a vaciar de contenido a la exclusión: "salvo que repercutan en las condiciones de empleo de los funcionarios», lo que en la práctica y en la dinámica Administración-sindicatos conduce al sometimiento a negociación de numerosas decisiones estrictamente organizativas pero a las que no es difícil encontrar una afectación o repercusión sobre la carrera, promoción, movilidad, lugar de trabajo, horario, etc., de los funcionarios. En segundo lugar, se dejan fuera de la negociación cuestiones como la regulación del ejercicio de los derechos de los ciudadanos y de los usuarios de los servicios públicos, así como el procedimiento de formación de los actos y disposiciones administrativos. En tercer lugar, la determinación de las condiciones de trabajo del personal directivo. En cuarto lugar, los poderes de dirección y control propios de la relación jerárquica. Y en quinto y último lugar, la regulación y determinación concretas, en cada caso, de los sistemas, criterios, órganos y procedimientos de acceso al empleo público y la promoción profesional. Además, hay que tener presentes los principios de legalidad y de cobertura presupuestaria que informan la negociación colectiva (art. 33.1 EBEP), así como la referencia expresa al respeto del contenido del EBEP y de sus leyes de desarrollo (art. 31.7 EBEP).

En cuanto al elenco de materias sujetas a negociación, tanto su ámbito como su objeto son lo suficientemente imprecisos e, incluso, contradictorios con algunas exclusiones como para exigir una concreción aplicativa ulterior que se vislumbra, cuando menos, compleja. Esto es especialmente así en lo que respecta a las «normas que fijen los criterios generales en materia de acceso, carrera, provisión, sistemas de clasificación de puestos de trabajo, y planes e instrumentos de planificación» [art. 37.1.c)], que habrá que cohonestar con la exclusión de la obligatoriedad de la negociación de «la regulación y determinación concreta, en cada caso, de los sistemas, criterios, órganos y procedimiento de acceso al empleo público y la promoción profesional» [art. 37.2.e)].

Normalmente, se someten a negociación criterios generales (evaluación del desempeño; planes y fondos para formación y promoción; determinación de prestaciones sociales y pensiones de clases pasivas; acción social; ofertas de empleo público; planificación de recursos humanos en la medida en que afecte a condiciones de trabajo), pero también se especifican materias concretas (aplicación del incremento de las retribuciones fijado en las 
Leyes respectivas de Presupuestos; la determinación y aplicación de las retribuciones complementarias de los funcionarios; el calendario laboral, horario, jornadas, vacaciones, permisos, movilidad funcional y geográfica).

En suma, el contenido de la negociación colectiva funcionarial viene regulado con unos contornos lo suficientemente imprecisos como para permitir incluir en ella prácticamente cualquier asunto o cuestión que, aun indirectamente, pueden afectar a las condiciones de empleo de los funcionarios, con el único límite infranqueable de la reserva de ley. Y aun ésta a efectos formales, pues también se pueden negociar materias sometidas a reserva formal o material de ley, en la medida en que en tal caso la negociación colectiva funcionarial desembocaría en la obligación para el órgano de gobierno de presentar un Proyecto de Ley conforme al Acuerdo concertado en la mesa de negociación. Más aún, se observa una tendencia implícita a que la potestad reglamentaria en la Función Pública se vea sustituida o, cuando menos, ejercida a través de la negociación colectiva funcionarial en cuanto procedimiento administrativo especial para elaborar instrumentos normativos que regulen las condiciones de empleo de los funcionarios. Y cuando no se trate de la potestad reglamentaria, la negociación colectiva funcionarial permitiría limitar y encuadrar el ejercicio de las potestades discrecionales de gestión del empleo público.

\section{Naturaleza de la negociación colectiva funcionarial} $y$ de los Pactos y Acuerdos

El resultado de la negociación colectiva funcionarial es la concertación de Pactos y Acuerdos en las mesas de negociación. La conceptualización de ambos instrumentos es imprescindible para intentar definir su naturaleza y eficacia.

Siguiendo con la regulación anterior, el EBEP traza una divisoria dicotómica con un criterio orgánico: órganos de gobierno de las Administraciones Públicas y el resto de órganos administrativos. Estos últimos, en la medida en que ostentan competencias de gestión sobre el personal a su servicio, podrán celebrar Pactos de aplicación directa que, objetiva y subjetivamente, se delimitan en función del ámbito competencial del órgano en cuestión.

Por su parte, los órganos de gobierno de las Administraciones Públicas podrán celebrar Acuerdos en el ámbito de sus competencias de empleo público, lo que comprende especialmente - aunque no de forma exclusiva- el ejercicio tanto de la potestad reglamentaria como de la función ejecutiva en materia de Función Pública. Esto incluye asimismo la potestad ejecutiva de iniciativa legislativa, por lo que la negociación colectiva también se extiende a materias sometidas a reserva de ley, si bien en este caso los Acuerdos carecen de eficacia directa y suponen la obligación por parte del órgano de gobierno de remitir un proyecto de ley conforme al Acuerdo en cuestión. No obstante, el ámbito natural de desenvolvimiento de los Acuerdos lo 
constituye más bien el de la potestad reglamentaria del órgano de gobierno, o sea, temas que pueden ser decididos definitivamente por él mismo. El EBEP predica la aplicabilidad directa del contenido de este último tipo de Acuerdos, lo que recalca con la especificación fundamental de que a esa aplicabilidad no le obsta la mera formalidad de modificar o derogar una disposición reglamentaria contraria. Aquí es donde más explícitamente se observa la intencionalidad legislativa de dotar a los Acuerdos de una eficacia normativa, incluso frente a reglamentos en contra, abriendo la puerta al reconocimiento de una nueva fuente jurídica en el ámbito de la Función Pública.

Pero antes es preciso tener en cuenta que la segunda característica de los Acuerdos —además de versar sobre competencias de Función Pública que son competencia de los órganos de gobierno de las Administraciones Públicas- es que precisan la aprobación expresa y formal de aquellos órganos no ya para que desplieguen toda su eficacia jurídica, sino incluso para su mismísima validez. De esta aprobación posterior por el órgano de gobierno dependen la naturaleza y la eficacia de los Acuerdos. Si estos Acuerdos, para ser tales, precisan de la aprobación del órgano de gobierno, la clave no estaría en el Acuerdo en sí -que, insistimos, sin aprobación no existiría, pues aquélla es requisito de validez y no sólo de eficacia-, sino en la virtualidad jurídica de la aprobación «expresa y formal» del órgano de gobierno. Y este acto de aprobación, que es el último requisito constitutivo del Acuerdo y el primero de su eficacia, volvería a protagonizar toda la polémica doctrinal sobre la naturaleza del Acuerdo (reglamento o contrato), toda vez que el EBEP reafirma su eficacia normativa.

A este respecto, la intencionalidad subyacente en el proceso de elaboración del EBEP es clara. Según el Informe del Comité de Expertos, los «Acuerdos de contenido normativo pueden considerarse en sí mismos una norma jurídica de obligado cumplimiento, una vez ratificados y publicados en el correspondiente Diario Oficial. Así debe precisarse en el Estatuto Básico. Esto supone, como ya ha admitido la jurisprudencia, la consolidación de una nueva fuente del derecho en este ámbito. Un tipo de norma negociada, que, por otra parte, no resulta una novedad absoluta en el ámbito del derecho administrativo, que hoy en día reconoce a otros efectos distintos (por ejemplo, en materia urbanística, educativa, económica, etc.) la existencia de pactos, acuerdos, convenios o conciertos, que por su contenido tienen eficacia normativa propia. Esa «norma negociada» debe tener, como es lógico, el rango jerárquico correspondiente al órgano que la firma o ratifica, insertándose con dicho rango en el ordenamiento jurídico. Por consiguiente, tales Acuerdos normativos pueden derogar, modificar o sustituir las normas reglamentarias, que hasta su celebración, hayan venido regulando las mismas materias. También los Pactos, si tuvieran contenido normativo, deben considerarse normas jurídicas, para lo cual precisan de la correspondiente publicación en un Diario Oficial» 22 .

22 Informe de la Comisión para el estudio y preparación del Estatuto Básico del Empleado Público, 25 abril 2005, n. 88. 
Se trataría, pues, de una «nueva fuente de Derecho» de la Función Pública cuyo objeto sería la regulación de condiciones de empleo propias del Derecho Administrativo. Y es que - como especifica SÁNCHEZ MoróN- «los Pactos y Acuerdos a que el EBEP se refiere tienen carácter jurídico público, al igual que las cláusulas de un contrato administrativo», por lo que «el EBEP está consolidando definitivamente una fuente de producción de Derecho Administrativo, esta vez de naturaleza bilateral y negociada ${ }^{23}$. Si esto es así, la negociación colectiva trascendería decisivamente el derecho del que trae causa para configurarse como un procedimiento administrativo especial ${ }^{24}$ por el que se producen Pactos y Acuerdos en cuanto instrumentos sui generis de Derecho Público con eficacia normativa sobre las condiciones de trabajo de los funcionarios. Es importante, pues, partir de la premisa de que nos encontraríamos, en todo caso, ante un procedimiento administrativo especial y ante instrumentos peculiares y originales de Derecho Público. Y es que, por mucha que haya sido la influencia o inspiración del Derecho Laboral, la negociación colectiva de los funcionarios ni es de naturaleza laboral ni menos aún se sujeta a aquél. Nos encontramos ante el tradicional fenómeno de administrativización de instituciones privadas, como ya ocurriera históricamente con el contrato administrativo: el Derecho de la Función Pública adaptaría y transformaría la negociación colectiva laboral a los principios estructurales de las Administraciones Públicas y a la peculiar relación de servicio que articula la vinculación estatutaria de sus funcionarios, configurando unas instituciones jurídico-públicas peculiares que serían tanto unas fuentes normativas propias (Pactos y Acuerdos) como el procedimiento que conduce a su elaboración (negociación colectiva). Habría, en todo caso, que distinguir estos dos planos: el procedimiento y el resultado del mismo, pues por mucho que aquél sea negociado y bilateral, el instrumento normativo en que desemboca no tiene por qué ser igualmente negociado y bilateral.

El EBEP no ha sido, en cambio, tan explícito o, si se prefiere, tan revolucionario o innovador en el sistema de fuentes de la Función Pública. Si hubiese querido introducir una nueva fuente jurídica en este ámbito, lo mínimo que habría que exigirle al legislador es claridad y seguridad, pues la inserción de una fuente normativa, negociada y bilateral, en el Derecho Administrativo plantea los suficientes problemas como para ser abordado de manera frontal y desde todos sus puntos de vista (procedimiento, competencia, relación con otras fuentes, control jurisdiccional, etc.).

23 M. SÁnchez Morón, «Clases de personal», en Comentarios a la Ley del Estatuto Básico del Empleado Público (Dir. M. SÁnchez Morón), Lex Nova, Valladolid, 2007, pág. 89.

24 Según MAURI, «el procedimiento convencional que se desarrolla en la mesa de negociación es el procedimiento específico para la elaboración de un tipo concreto de disposición general que el ordenamiento jurídico define como acuerdo de condiciones de trabajo de los funcionarios. En consecuencia, el procedimiento convencional es el procedimiento de elaboración de un tipo reglamentario que no deberíamos confundir con el reglamento mismo, aunque mantenga con él una relación de género y especie». J. MAURI, «Naturaleza y función de la negociación colectiva en la determinación de las condiciones de trabajo de los funcionarios públicos», en Presupuesto y Gasto Público, núm. 41/2005, pág. 187. 
Sea como fuere, el mantenimiento de la ulterior aprobación expresa y formal por el órgano de gobierno de lo acordado en la mesa de negociación permite continuar polemizando sobre si estamos ante un ejercicio negociado y peculiar de la potestad reglamentaria de los órganos de gobierno de las Administraciones Públicas o ante esas nuevas y originales fuentes del Derecho Administrativo.

\section{Eficacia de la negociación colectiva funcionarial} y de los Pactos y Acuerdos

Independientemente de su naturaleza jurídica, de lo que sí se ha preocupado el EBEP es de anudar unos efectos jurídicos concretos a la negociación colectiva y a los Pactos y Acuerdos.

Recordemos, en primer lugar, la eficacia normativa de Pactos y Acuerdos. Los Pactos «se aplicarán directamente al personal del ámbito correspondiente» (art. 38.2 in fine). En el caso de los Acuerdos hay que distinguir dos posibilidades. La primera es que si afectan a temas que pueden ser decididos de forma definitiva por los órganos de gobierno, el contenido de los mismos será directamente aplicable al personal incluido en su ámbito de aplicación, sin perjuicio de que a efectos formales se requiera la modificación o derogación, en su caso, de la normativa reglamentaria correspondiente. Por lo que los Acuerdos ni modifican ni derogan reglamentos, pero si éstos son contrarios a aquéllos deberán ser inaplicados, sin perjuicio de que, en aras del principio de seguridad jurídica, la Administración quede obligada a la modificación o derogación formal del reglamento en cuestión. La segunda posibilidad es que los Acuerdos versen sobre materias sometidas a reserva de ley, en cuyo caso el órgano de gobierno con potestad ejecutiva de iniciativa legislativa deberá elaborar, aprobar y remitir a las Cortes o a la Asamblea Legislativa, según se trate, el correspondiente Proyecto de Ley "conforme al contenido del Acuerdo y en el plazo que se hubiera acordado» (art. 38.3, párrafo segundo).

En segundo lugar, para el caso de que el órgano de gobierno no aprobara el pre-Acuerdo concertado en la mesa de negociación o se negara expresamente a incorporar lo acordado en el Proyecto de Ley correspondiente, «se deberá iniciar la renegociación de las materias tratadas en el plazo de un mes, si así lo solicitara al menos la mayoría de una de las partes» (art. 38.3, párrafo tercero).

En tercer lugar, el EBEP proclama solemnemente la vinculatoriedad de los Pactos y Acuerdos, en particular para la Administración, cuyos órganos de gobierno sólo podrán suspenderlos o modificarlos «excepcionalmente y por causa graves de interés público derivada de una alteración sustancial de las circunstancias económicas» y «en la medida estrictamente necesaria para salvaguardar el interés público» (art. 38.10). Vigente un Pacto o Acuerdo, la Administración no podría ejercer su potestad reglamentaria unilateral para aprobar una norma contraria a aquéllos, salvo que concurriesen las 
citadas circunstancias de excepcionalidad, causa grave de interés público y proporcionalidad de la norma unilateral. En cuarto lugar y último lugar, se prevé la prórroga automática de Pactos y Acuerdos, de año en año, si no media denuncia expresa de una de las partes.

En cualquier caso, la cualificación que la negociación colectiva funcionarial —en cuanto institución administrativa - adquiere en el EBEP, ya sea como procedimiento de elaboración, ya como fuente de producción, de instrumentos reguladores de las condiciones de empleo de los funcionarios públicos, bien merecería una singularización propia y una diferenciación neta respecto al derecho individual de ejercicio colectivo que formalmente la ampara. Una cosa es el reconocimiento de un derecho funcionarial a negociar colectivamente la condiciones de empleo y otra muy distinta es la regulación tanto de un procedimiento administrativo especial como de los instrumentos jurídico-públicos en que ese procedimiento desemboca. Otra consecuencia que se deriva de la regulación de la negociación colectiva funcionarial es la definitiva sindicalización de la misma, en detrimento de otras posibilidades, como los órganos de representación (Juntas o Delegados de Personal) o agrupaciones subjetivas de funcionarios creadas por las Leyes de Función Pública. No le falta razón a PARADA cuando afirma que el sindicalismo funcionarial «tiene que ver mucho más con la gestión del empleo público que con los llamados derechos individuales de los funcionarios ejercitados en forma colectiva», hablando en última instancia de «cogestión sindical» 25 .

\section{El carácter básico de la negociación colectiva funcionarial}

Un último aspecto merece señalarse en relación con la regulación que el EBEP hace de la negociación colectiva funcionarial. Y es el grado de detalle con que aquél determina prácticamente todos los elementos de la negociación colectiva. Grado de detalle que deviene exhaustivo en el caso de la representación y participación institucional de los funcionarios. En estos casos (negociación colectiva, representación y participación institucional) el Estatuto Básico es muy poco «básico». Pero a este respecto es preciso recordar que la regulación que hace el EBEP de la negociación colectiva no se ampara en la habilitación competencial de exclusividad sobre la legislación laboral (art. 149.1.7. ${ }^{\text {C }} \mathrm{CE}$ ), sino sobre la que ostenta sobre la legislación básica del régimen estatutario de los funcionarios (art. 149.1.18. ${ }^{\mathrm{a}} \mathrm{CE}$ ). Y al ser la negociación colectiva funcionarial una institución administrativa y no laboral, su normativa debería igualmente limitarse a lo básico.

Sin embargo, no es éste el caso. De una simple lectura de la mencionada regulación se observa la nula remisión en este Capítulo a las Leyes autonómicas en los eventuales elementos en los que el EBEP permitiese una configuración autonómica propia de la negociación colectiva funcionarial. Pero

25 R. Parada Vázouez, Derecho del empleo público, Marcial Pons, Madrid, 2007, págs. 105 y 110 . 
la legislación del Estatuto es, en este apartado, exhaustiva y agotadora en todos sus puntos (estructura negocial, ámbito objetivo y subjetivo, eficacia de la negociación). En especial, resulta sorprendente que las anteriores Mesas Sectoriales no puedan ser ahora creadas o previstas por la legislación autonómica de Función Pública, sino que el EBEP reserva a la negociación colectiva su implantación, pues cada Mesa Sectorial deberá ser creada en el seno de las Mesas Generales de Negociación. Se trata, en efecto, de una «reserva de negociación colectiva» indisponible por el legislador autonómico al venir prevista en la legislación básica.

La explicación de este alto grado de concreción y uniformidad del régimen de la negociación colectiva — según SÁNCHEz MORóN- radicaría, por un lado, en que «están aquí en juego derechos constitucionales de naturaleza sindical que las propias organizaciones representativas de los empleados consideran de inexcusable regulación por el Estado, con aplicación uniforme en todo el territorio nacional» y, por otro, en que «en términos sustantivos, se trata de la traslación de una pieza esencial de la legislación laboral (competencia exclusiva del Estado), con los matices correspondientes, al ámbito del Derecho de la función pública» ${ }^{26}$.

Sin embargo, el carácter exhaustivo y agotador de la regulación básica (obsérvese la contradicción interna) de la negociación colectiva funcionarial resulta paradójico incluso desde los mismos postulados inspiradores del propio EBEP. En efecto, la configuración de la negociación colectiva es directamente tributaria de la estructura objetiva de la Función Pública, pues las conocidas como unidades de negociación dependerían en gran medida de las agrupaciones objetivas o subjetivas (de puestos y de funcionarios) en que se estructure cada modelo autonómico de Función Pública y, en última instancia, estarían condicionadas por la organización administrativa propia de cada Administración Pública. De ahí que si el EBEP ha querido reducir los aspectos básicos de la Función Pública vinculados a la organización administrativa para dejar más margen de autonomía legítima a las Comunidades Autónomas, sorprende que ese margen no se extienda a la organización administrativa de la negociación colectiva funcionarial.

Por lo demás, si la explicación de la uniformidad de la regulación es su entronque con derechos constitucionales de naturaleza sindical o, peor aún, la importación de los convenios colectivos laborales a la Función Pública, habría que tener muy en cuenta que la negociación colectiva funcionarial constitucionalmente no forma parte del contenido esencial del derecho sindical (si así lo fuera, para empezar, sería necesaria su regulación por ley orgánica), sino que es un derecho accesorio y contingente ${ }^{27}$ de configuración

26 M. SÁnchez Morón, «La reforma del empleo público en el actual Estado de las Autonomías: propuestas de la Comisión para el estudio y preparación del Estatuto Básico del Empleado Público sobre el alcance de la legislación básica y la cooperación entre Administraciones», en Presupuesto y Gasto Público, núm. 41/2005, pág. 24.

27 De «contenido adicional» habla la jurisprudencia constitucional: SSTC 9/1988, de 25 de enero; 127/1989, de 13 de julio. Vid. A. BengoetXeA Alkorta, Negociación colectiva y autonomía colectiva en la Función Pública, Tirant lo Blanch, Valencia, 2005, págs. 71-73. 
legal que forma parte del «estatuto de los funcionarios públicos» (art. 103.3 CE) y, en su vertiente competencial, depende del artículo 149.1.18. ${ }^{\text {a }}$, donde el Estado no ostenta más que la legislación básica. La negociación colectiva funcionarial y los instrumentos normativos en que desemboca son instituciones jurídico-públicas del Derecho de la Función Pública, por lo que las alusiones a la legislación laboral en este punto no hacen sino sembrar la confusión sobre su naturaleza jurídica.

\section{Estatuto BÁsico y Clases de PERsonal}

Ya hemos indicado que la expresión «empleados públicos» no hace referencia a una clase o categoría de personal concreta, sino que es un concepto formal de conveniencia que engloba, en abstracto, a «quienes desempeñan funciones retribuidas en las Administraciones Públicas al servicio de los intereses generales» (art. 8.1 EBEP). Posteriormente, sí, el EBEP clasifica a los empleados públicos en funcionarios de carrera, en funcionarios interinos, en personal laboral y en personal eventual. Del elenco se ha caído otra de las grandes innovaciones del EBEP, el personal directivo, si bien pervive un Subtítulo específico para el "personal directivo», figura o función que ha salido malparada en la tramitación parlamentaria.

Consolidando, así, de forma definitiva la coexistencia de personal funcionario y personal laboral al servicio de las Administraciones Públicas, merece la pena destacar algunos aspectos importantes relativos a ambas categorías, así como la final regulación de los directivos públicos.

\section{Hacia una concepción sustantiva de los funcionarios}

Con cierta inercia histórica, el funcionario se sigue denominando de forma identificativa como "de carrera», aunque ésta se predique posteriormente por igual de todos los empleados públicos. La definición formal de los funcionarios de carrera (art. 9.1 EBEP) apela al nombramiento legal, a la naturaleza estatutaria del vínculo que les une a las Administraciones Públicas (por tanto, relación regulada por el Derecho Administrativo) y al desempeño de servicios profesionales retribuidos de carácter permanente.

Pero la novedad más relevante es la definición sustantiva de los funcionarios o, al menos, de una parte de ellos. En efecto, de forma reduccionista, pues no se aplica a todos los funcionarios, el Estatuto Básico del Empleado Público caracteriza sustantivamente unas funciones que necesariamente deben ser desempeñadas por funcionarios: «funciones que impliquen la participación directa o indirecta en el ejercicio de las potestades públicas o en la salvaguardia de los intereses generales del Estado y de las Administraciones Públicas» (art. 9.2 EBEP). Obsérvese que el funcionario no se limita a esas funciones, aunque el Estatuto sí que posibilita que dicha reserva sea tanto de las funciones a los funcionarios como de los funcionarios a tales funcio- 
nes, pues en ningún otro lugar del Estatuto se realiza una operación semejante para el personal laboral. Es decir, el Estatuto sí ha querido identificar aquellas funciones que necesariamente deben ser atribuidas a puestos ocupados por funcionarios, pero no ha intentado siquiera extraer la consecuencia de la opción constitucional por la regla general del funcionariado frente a la excepción particular del laboral, cosa que probablemente sí debería haber abordado pues no en vano tal delimitación sí tiene un carácter estructural propio de regulación por legislación básica. Esta tarea, por tanto, queda remitida al «legislador de desarrollo» del Estatuto (Estado o Comunidades Autónomas, según su ámbito propio), quien sí tendrá que delimitar para qué está cada categoría de personal, sobre la base de la regulación constitucional y de la STC 99/1987. No sería teóricamente posible que el legislador estatal o autonómico constriñese el concepto de funcionario a esas funciones explícitamente reservadas por el Estatuto Básico a los funcionarios de carrera, aunque el propio Estatuto Básico da ya una de arena al definir —en su Disposición Adicional Segunda ${ }^{28}$ - las funciones públicas en las Corporaciones Locales de manera más restrictiva que el criterio general recogido

28 «Son funciones públicas, cuyo cumplimiento queda reservado exclusivamente a funcionarios, las que impliquen ejercicio de autoridad, las de fe pública y asesoramiento legal preceptivo, las de control y fiscalización interna de la gestión económico-financiera y presupuestaria, las de contabilidad y tesorería». Obsérvese que ha desaparecido de esta versión el inciso final de su precedente, el ahora derogado artículo 92.2 de la LRBRL, que se refería también a "aquellas funciones que, en desarrollo de la presente Ley, se reserven a los funcionarios para la mejor garantía de la objetividad, imparcialidad e independencia en el ejercicio de la función». Precisamente esta cláusula articulaba la opción preferencial por el personal funcionario. Así lo entendió la STC 37/2002, de 14 de febrero, al señalar que aunque el artículo 92.2 LBRL no especificaba las funciones que debían ser desempeñadas por personal funcionario, sí recogía los principios que debían inspirar, en su desarrollo, la concreción de las funciones que debían ser desempeñadas por funcionarios públicos: objetividad, imparcialidad e independencia. Sensu contrario, sólo aquellos puestos que no requiriesen el respeto de esos principios podían ser provistos por personal contratado, tras la debida motivación exigida a toda excepción a una regla general. En suma, el personal contratado no podía ocupar aquellos puestos de trabajo que implicasen el ejercicio de funciones cuyo desempeño requiriese objetividad, imparcialidad e independencia. Vid., al respecto, STS 19 octubre 2005, que, en aplicación de esta doctrina, terminó por concluir, en primer lugar, que aquellos puestos de trabajo cuyas funciones o cometidos exterioricen una actividad de la Administración que tenga una directa trascendencia para la situación jurídica de otros sujetos de derecho (ajenos o no a su organización) y en la que por ello sean relevantes esas notas de objetividad, imparcialidad e independencia, habrán de ser necesariamente encomendados a personal funcionarial. En segundo lugar, el Tribunal Supremo señala que corresponde a la Administración la carga de demostrar que en las funciones de un determinado puesto resultan indiferentes esas notas de objetividad, imparcialidad e independencia. Y en tercer y último lugar, como consecuencia de todo lo anterior, la validez de los puestos de trabajo laborales estará condicionada inexcusablemente a que, en el acto que los haya creado con ese expreso carácter contractual y no estatutario, esté bien visible y justificado que los cometidos y funciones profesionales asignados a los titulares de tales puestos, por sus especiales características, hacen indiferente esos principios o criterios. Tras el EBEP, este inciso final que recogía esos principios generales de objetividad, imparcialidad e independencia de las funciones públicas ha desaparecido formalmente de la legislación básica de régimen local, haciendo difícil conciliar la opción constitucional por el régimen funcionarial con la normativa de Función Pública Local. 
en el artículo 9.2, posibilitando esa dinámica hermenéutica perversa de reducir lo funcionarial a las funciones públicas.

Aparentemente, la innovación es loable, si bien plantea dudas tanto en su articulación como en los principios que la sustentan. De entrada, la formulación literal supone un trasplante de la regulación de la excepción a la condición de nacionalidad para el acceso a puestos de trabajo en las Administraciones Públicas, impuesta por la jurisprudencia del Tribunal de Justicia de las Comunidades Europeas en el marco de la libre circulación de trabajadores $^{29}$. La identificación de lo que sea "participación directa o indirecta», «ejercicio de potestades públicas» o "salvaguarda de los intereses generales» es harto compleja, como se ha revelado ya en el ámbito del acceso ${ }^{30}$. Por otra parte, habría que preguntarse qué es lo que hace a un funcionario más apto que un contratado laboral para ejercer esas funciones. No será su mayor mérito y capacidad, pues éstos también rigen la contratación del personal laboral. Tampoco su imparcialidad, independencia y lealtad al Estado y a las Administraciones Públicas, pues aquéllas se articulan a través del régimen de incompatibilidades, aplicable por igual a funcionarios y contratados laborales ${ }^{31}$. En última instancia, la señal distintiva y diferenciadora de los funcionarios públicos es la vinculación permanente, pero en este contexto esta nota se difumina por la existencia de contratados laborales fijos y por el hecho de que tampoco son permanentes los titulares de órganos administrativos que más directamente ejercen potestades públicas y cuya actuación afecta directamente a la salvaguarda del Estado, de las Comunidades Autónomas y de las Corporaciones Locales.

La funcionalidad, pues, de la cláusula se limitaría a un principio informador de la separación organizativa de funcionarios y laborales en las Administraciones Públicas, si bien los conceptos jurídicos son tan indeterminados que el desarrollo legislativo y, más aún, la concreción aplicativa producirán resultados sumamente dispares entre Administraciones. No obstante, sorprende que la única manifestación en el EBEP de la opción preferencial constitucional por el régimen funcionarial en el empleo público - tal y como recoge la Exposición de Motivos- sea esta reserva de funciones públicas a los funcionarios.

\section{La relación laboral de empleo público}

Ya hemos indicado anteriormente cómo el EBEP, además de la legislación básica del régimen estatutario de los funcionarios públicos (ex art. 149.1.18. $\left.{ }^{a} \mathrm{CE}\right)$, también ha incluido en su texto la legislación laboral para

29 J. Guillén y J. Fuentetaja, «El acceso de los ciudadanos comunitarios a los puestos de trabajo en las Administraciones Públicas de los Estados miembros», en núm. 146 de esta REVISTA, 1998, págs. 467-500.

30 Artículo 57 EBEP.

31 Artículo 2.2 de la Ley 53/1984, de 26 de diciembre, de incompatibilidades del personal al servicio de las Administraciones Públicas. 
los contratados laborales al servicio de las Administraciones Públicas (ex art. 149.1.7. ${ }^{\mathrm{a}} \mathrm{CE}$ ). El EBEP define a este personal laboral de empleo público como «el que en virtud de contrato de trabajo formalizado por escrito, en cualquiera de las modalidades de contratación de personal previstas en la legislación laboral, presta servicios retribuidos por las Administraciones Públicas» (art. 11.1).

Se codifican, así, legislativamente las peculiares modulaciones que la legislación (acceso, incompatibilidades, etc.) y la jurisprudencia habían realizado sobre la normativa laboral, ante la imposibilidad de aplicarla tal cual a las relaciones de empleo en las Administraciones Públicas. La doctrina había ya destacado la problemática configuración de esas modulaciones vía jurisprudencial, especialmente en materia de contratación temporal irregular, donde éstas no podían convertir a los trabajadores en fijos de plantilla o los despidos declarados nulos o improcedentes no podían desembocar en la reincorporación del trabajador con la condición de fijo de plantilla $^{32}$, alumbrando la distinción entre trabajadores fijos de plantilla y contratos indefinidos ${ }^{33}$. Todas estas modulaciones — según CANTERO- «estaban motivando la aparición de una relación de trabajo especial paraestatutaria para el personal laboral de la Administración, un nuevo régimen jurídico mixto para sus trabajadores, a caballo entre las normas administrativas y las normas laborales, que no tenía ninguna expresa previsión normativa y que se caracterizaba por el sometimiento del trabajador de la Administración al Derecho Laboral y, en buena parte, también al Derecho Público» ${ }^{34}$.

Tres van a ser los aspectos más importantes de esta normativa reguladora de la relación laboral de empleo público ${ }^{35}$ : su normativa aplicable, las modalidades de contratación laboral según su duración y la siempre

32 Vid. S. DEL SAz, Contrato laboral y Función Pública, Marcial Pons, Madrid, 1995, págs. 67-97.

33 Sentencias de la Sala Social del Tribunal Supremo de 7 de octubre de 1996, 11 de noviembre de 1998, 27 de mayo de 2002, 2 de junio de 2003 y 26 de junio de 2003, entre otras muchas.

34 J. Cantero Martínez, «Funcionarios y laborales en las Administraciones Públicas», conferencia pronunciada en Santander, el 6 de agosto de 2007, en el marco del Encuentro La reforma de la Función Pública: valoración y perspectivas (Dirs. M. BACIGALUPO y J. FuENTETAJA), del programa de Cursos de Verano de la Universidad Internacional Menéndez Pelayo, pág. 8 .

35 Sobre si este conjunto normativo laboral incluido en el EBEP configura una relación laboral especial, ciertamente, aquél sólo habla de las «especificidades» que la jurisprudencia habría destacado en la relación laboral de empleo pública, las cuales, a su vez, habrían obligado al legislador - al amparo del art. 149.1.7. ${ }^{\text {a }} \mathrm{CE}$ - a recoger esas "peculiaridades» aprobando las normas que regulan la «relación laboral de empleo público». Ello contrasta con la propuesta explícita del Informe de la Comisión y con un sector doctrinal laboralista bien representado en la misma [T. SALA FRANCO, «El personal laboral. La relación laboral especial de empleo público», en Comentarios a la Ley del Estatuto Básico del Empleado Público (Dir. M. SÁnChez Morón), Lex Nova, Valladolid, 2007]. En contra de esta caracterización, M. Godino Reyes, El contrato de trabajo en la Administración Pública, Civitas, Madrid, 1996, págs. 279-286, quien se fundamenta en el hecho de que la presencia de la Administración en la relación produce un desequilibrio en el sistema de fuentes laboral. 
polémica delimitación del ámbito laboral en el empleo público. En primer lugar, el personal laboral al servicio de las Administraciones Públicas se rige, primero, por las disposiciones especiales previstas en el EBEP (que pueden ser bien específicas para el personal laboral ${ }^{36}$, bien comunes para laborales y funcionarios al amparo de la expresión "empleados públicos») y, después, "por la legislación laboral y por las demás normas convencionalmente aplicables» (art. 7 EBEP). Sorprende que el EBEP no haya especificado la virtualidad del convenio colectivo en el caso de sus normas reguladoras de esta relación laboral de empleo público, pues en virtud del principio de norma más favorable para el trabajador laboral, aquella legislación laboral del EBEP podría verse superada en cada instrumento convencional, si bien habrá que entender que esta legislación laboral del EBEP constituye disposiciones legales de Derecho necesario. De lo contrario, vía convenios colectivos, la normativa aplicable al personal laboral, originariamente común con los funcionarios, puede experimentar un proceso de singularización y regulación colectiva propia que abocaría a una desigualdad estructural de tratamiento normativo que precisamente el EBEP quiere evitar. No obstante, se prevé alguna remisión en el EBEP que sí permitiría la creación de normas propias para los contratados laborales, como la prevista en materia disciplinaria en un aspecto tan importante como la tipificación de faltas y sanciones graves o muy graves [arts. 94.2.a) y 95 EBEP].

En segundo lugar, el EBEP establece tres posibilidades de duración del contrato: fijos, por tiempo indefinido y temporales. No aborda, en cambio, el mencionado aspecto de la contratación temporal irregular, lo que SALA critica pues supone abandonar la cuestión a la interpretación y aplicación jurisprudencial ${ }^{37}$.

Y en tercer y último lugar, la delimitación del personal laboral en el seno de las Administraciones Públicas. Siguiendo con la práctica de la regulación anterior, la legislación básica que es el EBEP no fija esa delimitación, remitiéndose a las Leyes de Función de Pública del Estado y de las Comunidades Autónomas. Sólo se recuerda la limitación de la novedad introducida por la cláusula de reserva funcionarial de las funciones que supongan participación, directa o indirecta, en el ejercicio de potestades públicas y en la salvaguarda de los intereses generales del Estado o de las Administraciones Públicas. Ningún rastro adicional de la preferencia constitucional por el régimen funcionarial frente al laboral, no obstante lo cual aquellas Leyes de Función Pública del Estado y de las Comunidades Autónomas sí tendrán que observar esta opción constitucional, que jugaría a modo de garantía institucional del régimen funcionarial frente a una eventual opción labora-

36 V.gr., negociación colectiva (art. 32); jornada de trabajo, permisos y vacaciones (art. 51); retribuciones (art. 27); sistemas selectivos (art. 61.7); clasificación del personal laboral (art. 77); provisión de puestos y movilidad (art. 83); situaciones (art. 92).

37 T. SALA Franco, «El personal laboral. La relación laboral especial de empleo público», en Comentarios a la Ley del Estatuto Básico del Empleado Público (Dir. M. SÁnCHez Morón), Lex Nova, Valladolid, 2007, pág. 122. 
lizadora más extensiva ${ }^{38}$. Finalmente, una gran vía de agua por la que se ha escapado la delimitación funcionarios-laborales han sido los organismos reguladores, a los que la Disposición Adicional Quinta vuelve a privilegiar singularizadamente según su ley de creación, que podrá establecer una delimitación propia. Resulta, en definitiva, criticable la indiferencia de opción del legislador básico al configurar el modelo.

\section{El personal directivo}

Una de las pretendidas innovaciones trascendentales del EBEP es la regulación del personal directivo, que se concibe como «factor decisivo de modernización administrativa» en la medida en que «su gestión profesional se somete a criterios de eficacia y eficiencia, responsabilidad y control de resultados en función de los objetivos» (Exposición de Motivos). Estas intenciones reformadoras, ya propugnadas por el Informe de la Comisión, quedaron rebajadas, en un primer momento, por el Proyecto de Ley, que caracterizó a este personal como optativo dentro de la legislación básica, y, finalmente, por la tramitación parlamentaria, que no sólo eliminó la reserva de ley sobre él ${ }^{39}$, sino que también lo dejó de clasificar como una clase de personal específica.

En suma, de lo poco que ha quedado en el EBEP se pueden destacar los siguientes trazos. En primer lugar, los «directivos» ejercen «funciones directivas profesionales» (que deberán ser definidas como tales por cada Administración). En segundo lugar, los puestos directivos pueden ser ocupados tanto por funcionarios como por laborales (salvo aquellas funciones directivas que impliquen el ejercicio de funciones públicas o que afecten a la salvaguarda de los intereses generales del Estado y Administraciones Públicas, en cuyo caso sólo podrán ser ocupadas por funcionarios). En tercer lugar, si el personal directivo es un contratado laboral, éste se someterá en-

38 Recordemos, una vez más, la STC 99/1987, de 11 de junio: «corresponde sólo a la Ley la regulación del modo de provisión de puestos de trabajo al servicio de las Administraciones Públicas, pues no otra cosa se desprende de la opción genérica de la Constitución (arts. 103.3 y 149.1.18) en favor de un régimen estatutario para los servidores públicos y de la consiguiente exigencia de que las normas que permitan excepcionar tal previsión constitucional sean dispuestas por el legislador, garantizándose, de este modo, una efectiva sujeción de los órganos administrativos, a la hora de decidir qué puestos concretos de trabajo puedan ser cubiertos por quienes no posean la condición de funcionario».

39 La deslegalización en el trámite parlamentario de la regulación del personal directivo ha sido muy criticada por SÁNCHEZ MoRón, quien destaca los problemas que ello puede plantear: «la regulación de un régimen específico para el personal directivo precisará introducir con toda probabilidad excepciones, modulaciones o modificaciones en relación con las normas legales aplicables a otro tipo de personal funcionario o laboral no directivo y no sólo en los concretos aspectos a que se refiere el artículo 13 del EBEP. Así, por ejemplo, en materia de retribuciones y algunos otros derechos, en materia de deberes, de situaciones administrativas, etc.». Y cita, en especial y en el ámbito del Estado, las previsiones de la Ley de Organización y Funcionamiento de la Administración General del Estado. M. SÁNCHEZ Morón, "Clases de personal», en Comentarios a la Ley del Estatuto Básico del Empleado Público (Dir. M. SÁnchez MoróN), Lex Nova, Valladolid, 2007, págs. 106-107. 
tonces a la relación laboral de carácter especial de alta dirección; en el caso de los funcionarios, éstos podrán ocupar los puestos directivos conforme al sistema general de provisión, aunque lo normal será que se trate de puestos de libre designación; por lo demás, la referencia a «funciones directivas profesionales» parece indicar que se pretende excluir al personal eventual, si bien este extremo no se especifica.

En cuarto lugar y en lo relativo a los requisitos para ser directivo, se mencionan principios para su designación (mérito y capacidad), así como criterios (idoneidad) y un procedimiento que garantice la publicidad y concurrencia. En quinto lugar, este personal estará sujeto a evaluación con arreglo a criterios de eficacia y eficiencia, responsabilidad por su gestión y control de resultados en relación con los objetivos que les hayan sido fijados. En sexto lugar, el EBEP deja fuera de la negociación colectiva las condiciones de empleo del personal directivo. Y en último lugar, la Disposición Final Tercera del EBEP ha modificado la Ley 30/1984, de incompatibilidades, para impedir que se autorice o reconozca compatibilidad alguna al personal directivo.

Hasta aquí el EBEP. Lo básico es, ciertamente, escueto, pretiriendo aspectos tan importantes como su cese ${ }^{40}$. Más aún, las incoherencias que presenta la regulación del personal directivo (de clase de personal a funciones directivas; de la reserva de ley a la regulación por reglamento; lo optativo frente a lo indisponible) responden en gran medida a la inercia histórica de la patrimonialización política de la Alta Función Pública en nuestro país ${ }^{41}$.

\section{Estatuto BÁSico y CARRERA}

La carrera es una realidad particular en el seno de la Función Pública de contornos imprecisos y de contenidos variables. No obstante, se ha erigido en un lugar común imprescindible para políticos y administradores, ineludible en cualquier modelo de Función Pública. Nadie, en su sano juicio, negaría la existencia de carrera administrativa en una reforma por él propugnada. Cuestión muy diferente es el alcance y eficacia de la carrera que la legislación establezca.

Más aún, la carrera administrativa es la institución vertebradora de un sistema de Función Pública. De ella dependen tanto su estructura objetiva como los derechos en que se articula, con trascendencia funcional (provisión de puestos) y económica (retribuciones). Tradicionalmente, de la regulación y configuración estructural de la Función Pública dimanaban concretos derechos de ascenso cuando se producían vacantes en las categorías superiores, hasta el punto de erigir la carrera en un criterio estructural definidor del funcionario, en virtud de la cual se procedía a su inserción en una estructura objetiva o subjetiva que le posibilitaba una progresión consolida-

40 R. Parada Vázouez, Derecho del empleo público..., op. cit., pág. 68.

41 R. Jiménez Asensio, Directivos públicos, IVAP, Oñati, 2006. 
da. Por ello, un funcionario no es sólo un empleado al servicio de la Administración. Su relación con ésta se articula a través de una serie de vinculaciones organizativas que sitúan, «posicionan» u ordenan al funcionario según las mismas y lo insertan, estática y dinámicamente, tanto en la Administración como en la Función Pública. En definitiva, todos los elementos estructurales ordenadores de la Función Pública (cuerpo, grupo, puesto, grado, etc.) incluían la potencialidad del desarrollo profesional del funcionario público.

De esta dimensión institucional de la carrera, el EBEP ha pasado a una completa subjetivización de la misma al considerarla un derecho individual de los empleados públicos. Resulta, pues, necesario analizar tanto la estructuración del empleo público en el EBEP como la regulación específica que hace de la carrera, singularizando en ella otra de las grandes invenciones del EBEP: la evaluación del desempeño.

\section{Estructuración del empleo público}

En el capítulo dedicado a la estructuración del empleo público es donde más claramente se observa el alcance de la reducción de la intensidad de la legislación básica. Y es lógico, si se parte de la premisa de que los elementos de la Función Pública más conectados con la organización administrativa deberán ser definidos por cada Administración en el ejercicio de su potestad de autoorganización. Salvo en lo relativo a los grupos de clasificación profesional, el EBEP apenas dice nada sobre la estructuración objetiva o subjetiva del empleo público, permitiendo que las Leyes de Función Pública configuren sus modelos propios basándose en elementos objetivos (puestos de trabajo), subjetivos (funcionarios) o en ambos.

Desde una perspectiva objetiva, el EBEP continúa utilizando el concepto de puesto de trabajo, defragmentado en las «funciones, tareas o responsabilidades» (ex art. 73.2 EBEP) que le dotan de contenido. Esta perspectiva funcional del puesto de trabajo está presente por doquier en el Estatuto (v.gr., reserva de puestos a los funcionarios; condición de nacionalidad), soslayando razones organizativas. Además, los puestos de trabajo podrán ser objeto de agrupación y de ordenación. La agrupación de puestos de trabajo se hará en función de las características de aquéllos con la finalidad de organizar la selección, la formación y la movilidad (art. 73.3 EBEP). La ordenación de los puestos de trabajo, por su parte, se llevará a cabo mediante los correspondientes instrumentos organizativos (por ejemplo, las actuales relaciones de puestos de trabajo), que como mínimo comprenderán: la denominación de los puestos; los grupos de clasificación profesional; las agrupaciones funcionariales a que estén adscritos, en su caso; los sistemas de provisión y las retribuciones complementarias.

Ya desde una perspectiva subjetiva, de las disposiciones del EBEP se pueden extraer consecuencias relativas a una posible estructuración subjetiva tanto individual como colectiva. Así, el artículo 73.2 reconoce que los 
funcionarios ostentarán una "clasificación, grado o categoría» ${ }^{42}$ y articula - como veremos - la carrera horizontal del funcionario. Colectivamente, en cambio, los funcionarios se podrán agrupar en cuerpos, escalas, especialidades $\mathrm{u}$ otros sistemas que incorporen competencias, capacidades y conocimientos comunes acreditados a través de un proceso selectivo (art. 75.1 EBEP). En cualquier caso, estas agrupaciones funcionariales se deberán crear siempre por Ley (art. 75.2 EBEP).

Finalmente, las agrupaciones funcionariales se clasifican en Grupos, según la titulación exigida para el acceso a aquéllas. Esta clasificación profesional se ha coordinado con la reciente reforma educativa. En principio, son tres los Grupos (A - título de Grado, B - título de Técnico Superior y C), subdividiéndose el primero y el último en dos: en el caso del Grupo C, Subgrupo C1 (Título de Bachiller o Técnico) y Subgrupo C2 (Título de Graduado en Educación Secundaria Obligatoria). Para las subdivisiones del Grupo A no se especifica la titulación de acceso, debiendo la Ley que crea cada agrupación funcionarial proceder a la clasificación de la misma en los Subgrupos A1 o A2 «en función del nivel de responsabilidad de las funciones a desempeñar y de las características de las pruebas de acceso» (art. 76, cuarto párrafo, EBEP).

GRUPOS CLASIFICACIÓN PROFESIONAL

\begin{tabular}{|c|c|l|c|}
\hline Grupo & Subgrupo & \multicolumn{1}{|c|}{ Título } & Equivalencia \\
\hline A & $\begin{array}{c}\text { A1 } \\
\text { A2 }\end{array}$ & Grado & $\begin{array}{c}\text { A } \\
\text { B }\end{array}$ \\
\hline B & & Técnico Superior & \\
\hline C & C1 & Bachiller-Técnico & Graduado Educ. Sec. Obligatoria \\
Agrupaciones \\
sin titulación
\end{tabular}

42 Elemento subjetivo individual que se erige en límite infranqueable para asignar funciones, tareas o responsabilidades distintas a las correspondientes al puesto de trabajo que desempeñen: artículo 73.2 EBEP.

43 Disposición Adicional Séptima. Otras agrupaciones profesionales sin requisito de titulación: "1. Además de los Grupos clasificatorios establecidos en el artículo 76 del presente Estatuto, las Administraciones Públicas podrán establecer otras agrupaciones diferentes de las enunciadas anteriormente, para cuyo acceso no se exija estar en posesión de ninguna de las titulaciones previstas en el sistema educativo. 2. Los funcionarios que pertenezcan a estas agrupaciones cuando reúnan la titulación exigida podrán promocionar de acuerdo con lo establecido en el artículo 18 de este Estatuto». 


\section{La carrera como derecho}

Como se indicó anteriormente, el Estatuto Básico realiza una completa subjetivización de la carrera administrativa al vincular a ésta no tanto a la estructura de la Función Pública como al estatuto subjetivo del funcionario. Es decir, la carrera como un derecho individual. Quizás no cabía otra posibilidad en esta Ley básica, una vez que ésta renunció a cualquier regulación consistente de la estructura objetiva de la Función Pública.

Si la carrera es un derecho individual del funcionario, se trata, en cualquier caso, de un derecho de configuración legal, de forma que su alcance y efectividad dependerán de la concreta regulación normativa que en cada momento se establezca. Este derecho informará tanto la legislación como la gestión de Función Pública, aunque difícilmente podrá cuestionar aquélla. $\mathrm{Y}$ es que la definición que hace de la carrera profesional del funcionario no puede ser más abstracta: "conjunto ordenado de oportunidades de ascenso y expectativas de progreso profesional conforme a los principios de igualdad, mérito y capacidad» (art. 16.2 EBEP). Obsérvese que, ya en su definición, el derecho ha quedado rebajado al nivel de «oportunidades» $\mathrm{y}$ «expectativas».

Sea como fuere, el EBEP presenta cuatro modalidades de carrera profesional, según se trate de carrera en sentido estricto o de promoción, pudiendo verificarse ambas horizontal o verticalmente. Antes de exponer estas modalidades, es preciso recordar que se trata de una regulación básica dispositiva (valga la contradicción en los términos), de la que podrán valerse las Leyes de Función Pública estatal y autonómicas. Más aún, el elenco ni siquiera es cerrado («entre otras», dice literalmente el art. 16.3 EBEP), por lo que la coherencia interna que el mismo presentaba originariamente ha quedado difuminada al permitir que se puedan organizar o idear otras modalidades.

La primera y más original de las modalidades es la carrera horizontal. Para organizar esta modalidad, el EBEP distingue dos aspectos esenciales: un elemento estructural subjetivo y una progresión basada en la valoración de méritos del funcionario. El elemento estructural subjetivo es la base de la carrera horizontal, porque ésta se desliga por completo del puesto de trabajo que se desempeña, el cual no cambia en esta modalidad. Como se mencionó en el capítulo relativo a la estructura del empleo público, el EBEP ya atisbaba la posibilidad de estructurar a los funcionarios conforme a este tipo de elementos (se citaban entonces la clasificación, la categoría o el grado). Es ahora cuando el EBEP extrae todas las consecuencias de este tipo de elementos subjetivos estructurales ${ }^{44}$ para organizar no sólo la carrera horizontal, sino cualquier carrera ${ }^{45}$. Para ello, el EBEP prevé la articulación

44 Aunque nada indica que haya conexión entre los artículos 16 y 17 (carrera horizontal) y el artículo 73.2 del EBEP.

45 Significativamente, el EBEP, en su Disposición Adicional Décima, establece que «la carrera profesional de los funcionarios de carrera se iniciará en el grado, nivel, categoría, escalón y otros conceptos análogos correspondientes a la plaza inicialmente asignada al 
de un sistema de elementos subjetivos (grados, categorías, escalones, etc.) que, por un lado, sustenten ascensos consecutivos y, por otro, tengan asignadas unas remuneraciones determinadas. Se constituye así un conjunto de elementos subjetivos, ordenados o jerarquizados de menor a mayor, donde el funcionario progresa sin cambiar de puesto de trabajo. Tan importante es este último extremo (el funcionario progresa subjetivamente pero no objetivamente, al no cambiar de puesto de trabajo) como el carácter retributivo del elemento subjetivo. Éste, en efecto y en última instancia, reduciría su virtualidad a las remuneraciones que cada grado, categoría o escalón tiene asignadas. La progresión es, pues, en las remuneraciones a través de aquellos elementos. Progresión retributiva, como en los trienios. Pero ni hay ascenso ni progreso profesional, las dos concreciones que el propio EBEP hace del concepto de carrera.

Pero en la carrera horizontal, además de la progresión en esos elementos subjetivos, también es fundamental establecer los criterios para que se produzca dicha progresión. A tal fin, el Proyecto de Ley vinculaba la carrera horizontal «al desarrollo de las competencias del puesto de trabajo y al rendimiento, evaluado y acreditado», pero este inciso ha desaparecido y la redacción final del EBEP señala que se deberá valorar la trayectoria y actuación profesional del funcionario, la calidad de sus trabajos, los conocimientos adquiridos, el resultado de las evaluaciones del desempeño de las que haya sido objeto y, por último y eventualmente, otros méritos y aptitudes por razón de la especificidad de la función desarrollada y la experiencia adquirida [arts. 17.b) y 20.2 EBEP]. Nótese que la mención de la «experiencia adquirida» es una velada o eufemística alusión a la antigüedad, que, como la jerarquía, han sido relegadas de manera ominosa.

Obsérvese la riqueza y complejidad de implantar esta modalidad de carrera, que va más allá de la nota derivada de producirse en el mismo puesto de trabajo, lo que ha merecido valoraciones diferentes según se vea como una desvirtuación del concepto de carrera ${ }^{46}$ o como una evolución de la misma $^{47}$. En efecto, más allá del hecho de no cambiar de puesto de trabajo,

funcionario tras la superación del correspondiente proceso selectivo, que tendrán la consideración de mínimos. A partir de aquéllos, se producirán los ascensos que procedan según la modalidad de carrera aplicable en cada ámbito».

46 PARADA ha sido sumamente crítico con esta modalidad, a la que no ha dudado en (des)calificar como «carrera de los inmóviles»: "Es fácil predecir en qué terminará esta supuesta carrera horizontal: en inventar una serie de grados, niveles o categorías que se adquirirán por permanecer en el mismo puesto de trabajo un determinado tiempo sin evaluación negativa en el desempeño, que será lo normal para el común de los funcionarios, y en vincular al reconocimiento de esos períodos de tiempo una retribución fija... Algo que en el empleo público español no tiene sentido porque ya se premia la antigüedad a través de los trienios, de forma que ascenso horizontal terminará siendo para el funcionario inmóvil, pero sin calificación negativa que será lo normal, unos nuevos trienios o duodenios o sesenios, según el tiempo mínimo de permanencia exigido para el ascenso». R. PARADA, Derecho del empleo público..., op. cit., pág. 71. Del mismo autor, y con una perspectiva más amplia, "La degeneración del modelo de Función Pública», en núm. 150 de esta REvisTA, 1999, págs. 413-452.

47 M. FÉREZ FERNÁNDEZ, La carrera administrativa: nuevas perspectivas, Barcelona, 2006, pág. 57. 
la carrera horizontal exigirá, de entrada, organizar todo un «sistema de grados, categorías o escalones de ascenso». Posteriormente, será necesario establecer un procedimiento para valorar los criterios a los que se vincula la progresión en aquel sistema: quién valora; cómo se valora; posible participación del interesado; eventuales recursos ante las decisiones discrecionales de carrera que se adopten.

La segunda modalidad de carrera profesional es la carrera vertical, "que consiste en el ascenso en la estructura de puestos de trabajo por los procedimientos de provisión» [art. 16.3.b) EBEP]. Dependerá de la estructuración del empleo público que estos ascensos en la estructura objetiva de puestos de trabajo tengan alguna repercusión en la estructura subjetiva (si es que ésta existe, más allá del sistema que está en la base de la anteriormente estudiada carrera horizontal). Obviamente, la carrera vertical se verifica en una estructura jerarquizada de puestos, aunque el EBEP prescinda en su articulado incluso de dicho término.

Como tercera y cuarta modalidad, el EBEP prevé la promoción interna vertical y la promoción interna horizontal. La primera consiste en el ascenso desde una agrupación funcionarial de un Subgrupo o Grupo de clasificación profesional a otro superior, mientras que la segunda supone el acceso a agrupaciones funcionariales del mismo Subgrupo profesional. A diferencia de la carrera horizontal o vertical (que se verifica siempre dentro del mismo Grupo o Subgrupo), la promoción interna vertical supone la progresión de Grupo o Subgrupo, que es la técnica que jerarquiza u ordena las agrupaciones funcionariales. La promoción interna se equipara, en gran medida, al acceso al empleo público, a cuyos principios rectores expresamente se remite, sumándolos a los principios constitucionales de igualdad, mérito y capacidad, y cuyos requisitos deberán ser igualmente cumplidos (art. 56 EBEP). La particularidad, no obstante, respecto al acceso radica, por un lado, en el requisito de tener una antigüedad de, al menos, dos años de servicio activo en el Grupo o Subgrupo inferior y, por otro, en la superación de las correspondientes pruebas selectivas (art. 18.2 EBEP), cuya constitucionalidad ha sido confirmada por el Tribunal Constitucional ${ }^{48}$.

El juicio de ARROYO YANES - uno de nuestros mayores especialistas en la carrera administrativa funcionarial - no puede ser más rotundo: «la ordenación de la carrera de los funcionarios públicos constituye uno de los capítulos peor regulados de cuantos son abordados por la ley 7/2007, de 12 de abril, hasta el extremo de perder aquí el rótulo denominador que legitima su promulgación, y ello por dos razones: porque la flexibilización vía modalidades, frente a los deseos de los redactores del Proyecto de ley de fijar un marco dispositivo cerrado, ha acabado por desembocar, en el desenlace de la tramitación parlamentaria, en pura libertad de elección para los distintos legisladores de desarrollo y, en segundo lugar, porque se echa muy en falta el establecimiento de un régimen de garantías jurídicas que, por ser consus-

48 SSTC 31/2006, de 1 de febrero; 27/1991, de 14 de febrero; 151/1992, de 19 de octubre; 73/1998, de 31 de marzo. 
tancial a la propia idea de carrera administrativa, de modo obligado debería de figurar en el denominado estatuto básico ${ }^{49}$.

\section{La evaluación del desempeño}

El último gran elemento innovador de la carrera - aunque, como se verá, la trascienda-, y probablemente el reto más arduo de implantar que plantee el EBEP, es la evaluación del desempeño. En un contexto general de lo que se ha dado en llamar la «cultura de la evaluación» en el sector público tanto de políticas y servicios públicos ${ }^{50}$ como de determinados colectivos de funcionarios (v.gr., militares, profesorado universitario). Más aún, el propio EBEP recogería, al menos, tres procedimientos o técnicas donde la Administración deberá proceder, en la gestión de sus recursos humanos, a otras tantas actividades de evaluación o valoración de la conducta, desempeño o trabajo del funcionario. Además de la evaluación del desempeño, ya hemos mencionado la valoración que habría que efectuar en el seno de la carrera horizontal y, por su parte y en el ámbito de las retribuciones complementarias, uno de los factores que habrá que tener en cuenta al establecerlas será «el grado de interés, iniciativa o esfuerzo con que el funcionario desempeña su trabajo y el rendimiento o resultados obtenidos» [art. 24.c) EBEP $]^{51}$

En lo que respecta estrictamente a la evaluación del desempeño, con carácter general, de la regulación básica que establece el artículo 20 del EBEP se deriva, en primer lugar, que la misma deberá ser implantada obligatoriamente por todas las Administraciones Públicas. Por tanto, y en segundo lugar, no hay una remisión a las Leyes de Función Pública que desarrollen el EBEP, por lo que la evaluación del desempeño podrá ser regulada reglamentariamente por las distintas Administraciones, sin perjuicio de que aquellas Leyes puedan desarrollar y determinar, en el marco del EBEP, la evaluación del desempeño en su ámbito competencial. Y, en tercer lugar, que la evaluación del desempeño tiene el ámbito subjetivo delimitado por el concepto formal «empleados públicos», por lo que afectará por igual a funcionarios y laborales.

Qué sea la «evaluación del desempeño» se puede aprehender por la definición que ofrece el propio EBEP: procedimiento mediante el cual se mide y valora la conducta profesional y el rendimiento o el logro de resultados.

49 L. M. ARroyo YANES, «La carrera administrativa en el Estatuto Básico del Empleado Público», conferencia pronunciada en Santander, el 7 de agosto de 2007, en el marco del Encuentro La reforma de la Función Pública: valoración y perspectivas (Dirs. M. BACIGALUPO y J. FuentetAJA), del programa de Cursos de Verano de la Universidad Internacional Menéndez Pelayo.

50 Agencia Estatal de Evaluación de las Políticas Públicas y la Calidad de los Servicios (Real Decreto 1418/2006, de 1 de diciembre).

51 De hecho y con carácter general, las retribuciones complementarias «son las que retribuyen las características de los puestos de trabajo, la carrera profesional o el desempeño, rendimiento o resultados alcanzados por el funcionario» (art. 22.3 EBEP). 
Así pues, «evaluación» entendida como medición y valoración, mientras que el objeto de la misma —el «desempeño»- haría referencia tanto a la conducta profesional como al rendimiento o al logro de resultados.

A la hora de configurar sus respectivos sistemas de evaluación del desempeño, las Administraciones Públicas deberán tener en cuenta los siguientes principios o criterios: transparencia, objetividad, imparcialidad, igualdad y sin menoscabar los derechos de los empleados. Poco más dice el Estatuto Básico sobre el procedimiento de evaluación en sí, preocupándose mucho más - para dotar de credibilidad al mismo- de sus efectos. Y es que el EBEP anuda necesariamente efectos a la actividad de evaluación, por lo que se descarta que tenga una eficacia meramente indicativa. No obstante, no concreta qué efectos concretos tendrá esa evaluación, dejando esta previsión a la legislación de desarrollo del EBEP. Ahora bien, sí prevé una serie de ámbitos donde necesariamente la legislación de desarrollo deberá especificar qué efectos, positivos o negativos, produce la evaluación. En relación con los primeros, la evaluación del desempeño deberá repercutir positivamente en la carrera profesional horizontal, en la formación (v.gr., acceso a opciones formativas), en la provisión de puestos de trabajo (especialmente en el concurso) y en la percepción de retribuciones complementarias.

En cuanto a sus efectos negativos, el EBEP señala que «la continuidad en un puesto de trabajo obtenido por concurso quedará vinculada a la evaluación de acuerdo con los sistemas de evaluación que cada Administración Pública determine, dándose audiencia al interesado, y por la correspondiente resolución motivada». La disposición tiene una gran trascendencia por su incidencia en el derecho al cargo y, en la medida en que la resolución es lesiva para el funcionario, se prevén las garantías de audiencia al interesado y el requisito de la motivación de la resolución. No obstante y precisamente por su incidencia directa en el mencionado derecho al cargo, quizás habría sido conveniente remitir su regulación a las leyes de desarrollo. En cualquier caso, el desarrollo normativo de la evaluación del desempeño deberá prever aspectos tan importantes, en este punto, como el número de evaluaciones negativas y el período de tiempo en que se realicen para que se produzca la remoción del funcionario.

Otros aspectos generales que deberá acometer la normativa serán el órgano evaluador (el superior jerárquico u otro), la frecuencia de las evaluaciones (anuales, cada dos años, etc.), limitación de las posibilidades de evaluación para evitar que sean irreales o inflacionistas (v.gr., que se evalúe con la máxima puntuación o con la misma a todos los empleados de una unidad), mecanismos de garantía de la evaluación (refrendos, comités paritarios, etc.) y, por supuesto, procedimientos de impugnación propios que eviten aluviones de recursos administrativos y contenciosos.

La implantación de la evaluación del desempeño en nuestro empleo público será compleja y polémica tanto en su fase normativa como, especialmente, en su fase aplicativa. La cabal comprensión de la finalidad de este nuevo procedimiento será fundamental para que no se intente arreglar vía evaluación del desempeño lo que se debe afrontar vía régimen disciplinario. 
La normativa de desarrollo deberá ser muy precisa y no dejar excesivo margen a la discrecionalidad, porque las consecuencias o efectos que se han previsto para la evaluación (retribuciones, carrera o cese en el puesto de trabajo) previsiblemente suscitarán una gran conflictividad. De hecho, en otros modelos de Función Pública donde están históricamente arraigados, se replantea la ineficacia de los sistemas de evaluación desde el mero punto de vista de los costes (Estados Unidos ${ }^{52}$ ) o se abdica de la intención de adscribirles efectos sobre las retribuciones (Unión Europea ${ }^{53}$ ). Sea como fuere, la puesta en marcha de estos procedimientos de evaluación exigirá un gran esfuerzo de formación entre los gestores de recursos humanos en el seno de las Administraciones Públicas, profesionalización de la gestión que está muy presente en las intenciones del propio EBEP.

\section{ESTATUto BÁsICO Y DERECHOS Y DEBERES}

Finalmente, abordaremos en este trabajo el tema de los derechos y deberes de los empleados públicos, lugar postrero que no casa bien con su ubicación en la Ley 7/2007, pues significativamente el EBEP comienza - tras la regulación de las premisas de su objeto, ámbito de aplicación y clases de personal- precisamente con el «estatuto subjetivo» de los empleados públicos, que vendría integrado por sus derechos y deberes, anteponiéndose al «estatuto objetivo» de la estructura de la Función Pública, que la legislación básica remite casi en su totalidad a las potestades de organización de las Administraciones Públicas.

En efecto, el Estatuto se vacía objetivamente y se pretende dotar de contenido a través de la definición de un estatuto subjetivo de derechos y obligaciones que sería lo común al conjunto de empleados públicos. De manera que lo que desde el punto de vista de la organización quebraría la descentralización, pretende alcanzarlo el Estatuto Básico a través, por un lado, de la proclamación de unos principios o valores esenciales (que denomina «fundamentos de actuación»: art. 1.3 EBEP) y, por otro, de la exhaustiva regulación de los derechos y deberes de funcionarios y laborales. Se compensaría, así, axiológicamente lo que se pierde estructuralmente.

El fenómeno, en realidad, es común a modelos fragmentados de Función Pública. Por ejemplo, en el Reino Unido, donde la diferenciación viene no a través de la descentralización, sino de las reformas de desconcentra-

52 Vid. L. G. Nigro, F. Nigro y J. E. Kellough, The New Public Personnel Administration, Thomson/Wadsworth, Belomont, 2007, págs. 165-197; J. E. KELlOUGH, «Employee Performance Appraisal in the Public Sector: Uses and Limitations», en Public Personnel Management. Current Concerns, Future Challenges (ed. N. RicuccI), 4. ${ }^{a}$ ed., Longman, New York, 2006, págs. 177-189. En especial, J. S. BowmAN, «At Last, An Alternative to Performance Appraisal: Total Quality Management», en Public Administration Review, vol. 54 (29), marzoabril 1994, págs. 129-136, quien critica las evaluaciones individuales del rendimiento y aboga por su abandono porque plantean más problemas que beneficios producen.

53 J. Fuentetaja, "La reforma de la Función Pública Europea», en Revista de Derecho Comunitario Europeo, núm. 19, 2004, págs. 751-785. 
ción de la década de los noventa, se advirtió que «los valores intangibles y compartidos del Civil Service estaban ligados en el pasado a caracteres tangibles que los funcionarios tenían en común en todos los Ministerios, incluyendo remuneraciones comunes, así como comunes sistemas de estructuración en grados y de métodos de reclutamiento y promoción. Estos elementos tangibles recordaban a los funcionarios que servían a un "empleador" común y que tenían idénticos objetivos» ${ }^{54}$. Pero al haber acabado con esos sistemas comunes de remuneración, estructuración en grados, reclutamiento y promoción, se minó «el sentido de ser un servidor público (public servant) con todo lo que eso implica» ${ }^{55}$, por lo que se procedió a una reflexión axiológica para refundar la unidad del Civil Service en los valores esenciales del mismo ${ }^{56}$.

Consecuentemente, la regulación que hace el EBEP de los derechos de los empleados públicos (por tanto, de funcionarios y de laborales) es tan amplia como intensa. Así, tras el catálogo de derechos individuales (art. 14) y de derechos individuales ejercidos colectivamente (art. 15), se suceden los Capítulos relativos al derecho a la carrera profesional y a la promoción interna; a los derechos retributivos; al derecho a la negociación colectiva, representación y participación institucional, así como el derecho de reunión; y el derecho a la jornada de trabajo, permisos y vacaciones.

No es éste el lugar de hacer un análisis del complejo y completo elenco de derechos y obligaciones previstos en el EBEP ${ }^{57}$, pero sí se pueden aventurar dos apreciaciones generales. La primera es que, como ya se advirtió, contrasta la exhaustividad de la regulación que hace el EBEP en lo tocante a los derechos de los funcionarios, que en algunos momentos roza los límites de lo amparado por la legislación básica. La segunda, que se advierte una cierta subjetivización de auténticas instituciones o procedimientos de la Función Pública que deberían tener un tratamiento diferenciado de los

54 Fifth Report from the Treasury and Civil Service Committee: The Role of the Civil Service, House of Commons (Session 1993-1994), n. 75

55 Ibid.

56 The Role of Civil Service, n. 72: «Los valores de imparcialidad, integridad, objetividad, selección y promoción basados en el mérito y responsabilidad deben actuar como caracteres unificadores del Civil Service británico. Son tan importantes hoy en día como lo fueron en el siglo pasado: su importancia no debería disminuir en el siglo venidero. Creemos que la razón para la existencia de una Función Pública permanente y políticamente imparcial es tan imperiosa actualmente como lo ha sido a lo largo de este siglo. El principio de selección y promoción basados en el mérito debe representar el cimiento del Civil Service. La importancia de los valores de integridad, imparcialidad, objetividad y responsabilidad radica en las características de las tareas que la Función Pública está llamada a desempeñar. Estos valores reflejan y no imposibilitan los trabajos a realizar y afectan tanto a los funcionarios que sirven al público como aquellos que sirven directamente a los Ministros. Tales valores pueden y deben actuar como una fuerza unificadora para todo el Civil Service».

57 Vid., al respecto, los excelentes estudios de F. CAstillo Blanco, "Los derechos individuales de los empleados públicos», "Los derechos retributivos de los empleados públicos», «Jornada, permisos y vacaciones» y «Los deberes de los funcionarios públicos», en Comentarios a la Ley del Estatuto Básico del Empleado Público (Dir. M. SÁnchez Morón), Lex Nova, Valladolid, 2007, págs. 131-198, 227-286, 321-355 y 357-393, respectivamente. 
estrictos derechos funcionariales. Es el caso de la carrera administrativa, de la evaluación del desempeño o del procedimiento de negociación colectiva.

Finalmente, y por su originalidad en nuestra legislación de Función Pública, resulta obligado hacer mención del Código de Conducta de los empleados públicos, configurado por los principios éticos (art. 53 EBEP) y por los principios de conducta (art. 54 EBEP). La eficacia jurídica del mismo se reduce a informar la interpretación y aplicación del régimen disciplinario (art. 52 in fine), virtualidad clarificada aún más por la Exposición de Motivos cuando señala que las reglas del Código de Conducta «se incluyen en el Estatuto con finalidad pedagógica y orientadora, pero también como límite de las actividades lícitas, cuya infracción puede tener consecuencias disciplinarias». En realidad, el Código de Conducta no tipifica faltas disciplinarias, lo que lo separa de su modelo británico (al que emulan infructuosamente las Funciones Públicas continentales) ${ }^{58}$, y explica la conclusión de PARADA de que aquél no es más que la «búsqueda de una imagen corporativa» 59 .

58 En efecto, en el Reino Unido el Código de Conducta forma parte de las condiciones de empleo de cada funcionario y establece el marco constitucional y administrativo en el que trabajan todos los funcionarios, así como los valores que éstos deben observar. Es importante destacar este valor normativo del Código de Conducta en el Civil Service pues explica su radical diferencia respecto a pretendidas transposiciones continentales desprovistas de eficacia jurídica. Aquel valor normativo le viene dado por el hecho de que el Civil Service es competencia de la Corona (o sea, del Ejecutivo o del Gobierno), que puede desarrollar y completar el régimen jurídico de los empleados a través de diferentes instrumentos, entre los que encontramos los Códigos de Conducta, los cuales integran aquel régimen jurídico, vinculando a los empleados. Este Código de Conducta se centra especialmente en los derechos y obligaciones de los empleados públicos, definiendo y tipificando, consecuentemente, auténticas faltas y sanciones disciplinarias. Lejos, pues, del principio de legalidad del Derecho de la Función Pública continental. Cuando en España, Francia o Italia, por ejemplo, el Gobierno aprueba documentos que titula "Códigos de Conducta», su eficacia no deja de ser admonitoria y, si se quiere, explicativa o interpretativa de lo que la Administración entiende debe ser un adecuado comportamiento de los empleados públicos, pero ni por asomo podrían establecer faltas o sanciones disciplinarias. A diferencia de muchos países de la Europa continental, la concepción del Civil Service como una "prerrogativa de la Corona» lo aleja del principio de legalidad en esta materia.

59 R. Parada VázQuez, Derecho del empleo público, op. cit., pág. 75. 



\title{
LA REPRESENTACIÓN INTERNACIONAL EN EL DEPORTE Una primera aproximación
}

\author{
Marta Lora-Tamayo Vallvé \\ Profesora Titular de Derecho Administrativo \\ Universidad Nacional de Educación a Distancia
}

1. INTRODUCCIÓN.-2. LA REPRESENTACIÓN INTERNACIONAL EN EL ÁMBITO DE LOS JUEGOS OLÍMPIcos. El Comité Olímpico Internacional (COI) y los Comités Olímpicos Nacionales: 2.1. Principales funciones de los Comités Olímpicos Nacionales (CON). La inevitable politización y absorción por las estructuras administrativas-deportivas nacionales. 2.2. La geografía olímpica y el problema del reconocimiento de los Comités Olímpicos Nacionales: 2.2.1. Los continentes olímpicos. Excepciones. 2.2.2. El reconocimiento de los Comités Olímpicos Nacionales. Criterios: a) Criterio deportivo: existencia de una presencia deportiva mínima. b) Criterio jurídico-político. Estado, país y territorio olímpico.-3. LA REPRESENTACIÓN INTERNACIONAL EN EL ÁMBITO DE LAS FEDERACIONES INTERNACIONALES.-4. El CASO ESPAÑOL. ANTECEDENTES, PROBLEMÁTICA, ¿'PERSPECTIVAS DE FUTURO?: 4.1. El problema legislativo. Las leyes autonómicas del deporte y la representación internacional. 4.2. Controversia y problema competencial en sede jurisdiccional. 4.3. De la "vía de hecho" catalana a la "guerra de las camisetas» en el Congreso de los Diputados.

\section{RESUMEN}

La representación internacional en el deporte presenta diversos aspectos jurídicos que plantean problemas de interesante discusión. La Carta Olímpica habla de naciones e identifica a las mismas con aquellas que estén reconocidas internacionalmente. Sin embargo, en los últimos tiempos existen «naciones» o regiones que no son Estados que han obtenido una representación internacional independiente del Estado al que pertenecen. La inscripción de la Federación Catalana de Hockey sobre Patines en la Federación Internacional de Hockey ha sido muestra de ello. ¿Será posible una representación internacional olímpica de Cataluña o el País Vasco en el ámbito de unos JJ.OO.? La legislación española y diversas sentencias del Tribunal Supremo español lo impiden; sin embargo, estas CC.AA. intentan lograr su reconocimiento internacional independientemente de la legislación estatal que regula la representación internacional de España como un solo Estado.

Palabras clave: representación internacional; federaciones internacionales; COI; soberanismo deportivo.

\section{ABSTRACT}

The international representation in sport presents several juridical aspects that raise problems of interesting discussion in the frame of an International Congress. The Olympic Chart speaks about nations and identifies the same ones with those that are recognized internationally. Nevertheless in the last times there exist «nations» or regions that are not recognized states that have obtained international representation independent from the State to which they belong. The inscription of the Catalan Federation/Governing body of Roller Skating in the International Roller Skating governing body has been a sample of it. Will an international Olympic representation of Catalonia be possible, in the frame of the Olympic Games?, the Spanish legislation and various judgments of the Supreme Spanish 
Court avoid it. But Catalonia try to achieve her international recognition independently of the spanish legislation that regulates/implements international representation of Spain as an alone/unique State.

Key words: nations without state; internacional representation in sports; sport law; internacional governing bodies.

\section{INTRODUCCIÓN}

Al cierre de este artículo homenaje a mi maestro el profesor PARADA, la Selección Española de Baloncesto ha perdido el Eurobasket por tan sólo un punto. La crisis de las banderas en el País Vasco y Cataluña amenaza con la desaparición de los pocos símbolos nacionales que quedan ya. En el Congreso de los Diputados se desata una «guerra de camisetas» para, a falta quizá de argumentos jurídicos, defender las selecciones respectivas. Sólo el deporte es capaz de hacer vibrar, sentir, reír, llorar y desgañitarnos con pasión al grito de «¡España! ¡España! A por ellos, oé», que parece, a falta de un himno con letra, reclamado también por los deportistas, haberse erigido en el nuevo himno nacional.

El deporte es en la actualidad, y sin exageración alguna, el ámbito de representación internacional más visible que ofrecen los Estados; la popularidad del deporte de masas y la influencia de la expansión audiovisual de los acontecimientos deportivos hacen de éste un auténtico escaparate que muestra el poder y la debilidad de aquellos que lo representan. Por esta razón ha sido, al mismo tiempo, una herramienta de fácil politización, de plástica representación de los problemas internos dentro de un Estado y de las conflictivas relaciones internacionales entre otros ${ }^{1}$.

1 Vid. T. Walter y J. R. Champion, «Sports law» (in a nutshlell), West Grop. St. Paul, Minnessota, 2000, pág. 252. Definen los boycotts en el ámbito de los deportes olímpicos cuando determinados países pretenden obtener objetivos políticos con la no participación en los mismos. Un ejemplo de boycott fue el de los Estados Unidos en las Olimpiadas de 1980, como protesta a las actividades de la Unión Soviética en Afganistán. Los JJ.OO. de 1980 estaban previstos en Moscú y la Unión Soviética correspondió posteriormente con el boycott a los JJ.OO. de Los Angeles en 1984. Normalmente, estos boycotts se basan en una motivación política (como, por ejemplo, la protesta en los años ochenta contra el apartheid en Sudáfrica). Jurídicamente, los boycotts son claramente ilegales cuando su propósito es inducir o implicar mediante medidas de coerción que violarían la Carta de las Naciones Unidas. En el mismo sentido, también son ilegales cuando su propósito es confirmar el no reconocimiento diplomático en la violación de las reglas de Derecho internacional. En determinadas circunstancias, los boycotts pueden sancionarse con ciertas medidas disciplinarias. La justificación jurídica que impidió la representación de EE.UU. en las Olimpiadas de Moscú de 1980 permitió que un juzgado federal de distrito (federal district court) pudiera sostener que el USOC (Comité Olímpico de Estados Unidos) ostentaba la autoridad suficiente para decidir no enviar al equipo de las Olimpiadas de Verano, incluso si este plan estaba basado en razones no relacionadas directamente con el deporte, es decir, con consideraciones políticas. Al llegar a esta decisión, el tribunal rechaza un argumento basado en que las previsiones de la Amateur Sports Act de 1978 relacionadas con los derechos de los atletas superaban la competencia de la autoridad del USOC. En este sentido, también estableció que no existía una causa privada de acción al amparo de esta disposición que estableciera un derecho 
En los últimos tiempos, y desde la caída del Muro de Berlín, el deporte ha sido utilizado como forma de reivindicación de los intereses políticos, independentistas o nacionalistas de algunas regiones, Estados federales o, en nuestro caso, Comunidades Autónomas que pretenden una representación internacional separada de la del Estado al que pertenecen.

Es una cuestión delicada tras la que laten no sólo intereses estrictamente deportivos, sino y sobre todo un mar de fondo político y muchas veces histórico cuya solución, creo que a priori, no debe ser resuelta únicamente por las instituciones deportivas, ni por los Comités Olímpicos, ni por las federaciones internacionales; la autorregulación deportiva encuentra sus límites en el momento en que se publifica y monopoliza la actividad.

Independientemente de esta opinión, no argumentada ni justificada todavía, es necesario, y sobre todo para el caso español, aclarar algunos conceptos, describir el iter de reconocimiento internacional de las federaciones, de los Comités Olímpicos, calificar jurídicamente estos procesos para dar algo de rigor a un tema que, debido a su politización, está siendo en muchos casos interpretado erróneamente, desde una perspectiva jurídico-pública, y es entonces cuando se producen las tensiones, por la ausencia de un conocimiento claro de la normativa deportiva y de la interpretación que de ella deba llevarse a cabo.

No se trata, pues, de realizar un ejercicio teórico acerca del concepto de Estado y su reconocimiento internacional, sino que de forma muy somera, y quizá pecando de ligeros ${ }^{2}$, por expreso deseo del homenajeado, realizaremos una descripción de lo que está ocurriendo en el mundo deportivo y sus implicaciones jurídicas.

Para ello debemos partir de una primera idea, y es que, como advierte Palomar Olmeda ${ }^{3}$, el modelo de organización del deporte es un modelo que podemos calificar de piramidal y en el que la premisa básica estriba en la necesidad de que los estatutos de cada asociación o federación respeten los de ámbito superior en los que, respectivamente, se integran y que culmina en un modelo nacional que excluye, con carácter general, un modelo regional (en el ámbito internacional) que podría proliferar en virtud de las distintas formas nacionales de descentralización territorial.

El marco internacional del deporte parte, en principio, de que sólo pueden producirse afiliaciones de las asociaciones nacionales a las asociaciones internacionales, entendiéndose por tales las que responden a represen-

a competir en las Olimpiadas frente al establecimiento de la prohibición de los atletas a no competir (DeFranzt v. United States Olympic Committee, 1980).

2 Para una visión completa del tema, vid. al respecto. M. LORA-TAMAYO VALLVÉ, «La representación internacional en el deporte. Una primera aproximación», Revista Jurídica del Deporte, núm. 13, 2005, págs. 33 a 59; La representación internacional en el deporte, Ed. Dykinson, Madrid, 2006.

3 A. Palomar Olmeda, "Consideraciones generales sobre la actualidad del movimiento olímpico y sus principios rectores», RJD, núm. 12, 2004, pág. 155. 
tación de países que gozan de independencia política y que están admitidas como tales por la comunidad internacional ${ }^{4}$.

El segundo punto fundamental que centra la polémica es la consideración de estas entidades como meras asociaciones privadas y, por lo tanto, su representación internacional no tendría más relevancia que la que pudiera

4 Sobre este punto es necesario recordar que el término reconocimiento por la comunidad internacional —o el Derecho internacional- es un término que responde a un concepto previo acuñado por el Derecho internacional. En este sentido, el Instituto de Derecho Internacional en el año 1936 definió el reconocimiento de Estados como «el acto libre por el cual uno o varios Estados constatan la existencia sobre un territorio determinado de una sociedad humana políticamente organizada, independiente de cualquier otro Estado existente, capaz de observar las prescripciones del Derecho Internacional y manifiestan consiguientemente su voluntad de considerarlo como miembro de la Comunidad Internacional (...)». Este reconocimiento puede ser hecho por los Estados o por las organizaciones internacionales.

El reconocimiento de la independencia por parte de la comunidad internacional implica el reconocimiento de que un Estado goza de soberanía, y en este sentido debemos subrayar que la diferencia entre autonomía política limitada y soberanía es clara, desde una perspectiva de Derecho internacional. Soberanía es «un conjunto de competencias atribuidas al Estado por el Derecho Internacional, ejercitables en un plano de independencia e igualdad respecto de otros Estados...» (Comisión Permanente de Justicia Internacional, 1923). Su manifestación más importante en las relaciones internacionales es la capacidad de los Estados para obligarse con otros y empeñar su responsabilidad internacional en caso de incumplimiento.

La Corte de La Haya, en el asunto Lotus (Comisión Permanente de Justicia Internacional, 1927), indica que la soberanía a la que se refiere el Derecho implica ineludiblemente exclusividad, que se traduce de una forma evidente y palpable en la exclusividad en el ejercicio de las competencias. Este concepto no puede ser fraccionado, como han pretendido en algunos momentos recientes algunas organizaciones internacionales deportivas, e indicar que en materia de deporte se produce una actuación autónoma, ya que esta característica es común a muchos de los fenómenos territoriales de los Estados compuestos que componen la comunidad internacional.

Basta con analizar la Constitución española, que reconoce en el artículo 148.1.17 como competencia exclusiva de las Comunidades Autónomas «la promoción del deporte y de la adecuada utilización del ocio». En dicho ámbito, el artículo 149.1, que se refiere a las competencias del Estado, no establece que el mismo tenga competencia alguna en materia de deporte. Desde esta perspectiva, la actuación en el ámbito general del Estado español se funda en otros títulos como los relativos a las relaciones exteriores, la seguridad pública o la defensa de los consumidores, entre otros.

Desde esta perspectiva y en un análisis somero, puede indicarse que existen diversos textos constitucionales que atribuyen a los gobiernos regionales facultades para la gestión del deporte que no están condicionadas por leyes estatales.

El Derecho internacional considera que sólo tienen la condición de Estados independientes los que son considerados Estados soberanos. Esta interpretación ha sido planteada y reforzada recientemente por la Comisión de Arbitraje, órgano asesor de la Conferencia sobre el establecimiento de la paz en Yugoslavia (1991-1995).

En el seno de esta institución se recuerdan los principios básicos del Derecho internacional, que parten de que la existencia o no de un Estado es una cuestión de hecho que ha de tratarse en función de los principios del Derecho internacional que determinan los elementos constitutivos del Estado, que se define como una comunidad compuesta por territorio y una población sometidos a un poder político organizado y cuya nota característica es la soberanía (Dictamen núm. 1, de 29 de noviembre de 1991, y Dictamen núm. 8, de 4 de julio de 1992).

Soberanía que permite la existencia de un gobierno capaz de establecer y mantener el orden interno y apto para las relaciones internacionales de forma independiente. Esta afirmación deriva directamente de lo establecido por la Corte Internacional de Justicia en el asunto del Sahara Occidental, de 1995. 
tener una empresa o una ONG con sedes en diferentes países, o si bien las federaciones deportivas, de alguna manera, representan internacionalmente, cada una en su propio ámbito, a un Estado en las competiciones internacionales oficiales por ellas organizadas.

Si jurídicamente encaja mejor la segunda fórmula, entonces estaremos hablando de la representación internacional de los Estados en el ámbito deportivo, y no sólo de sus federaciones privadas, y como consecuencia adquirirán pleno sentido, en este ámbito material, las posiciones comunes en el Derecho internacional que parten de la base de que, en las proyecciones exteriores en el seno de las estructuras complejas, la acción exterior corresponde en exclusiva al Estado soberano, que resulta el único responsable del cumplimiento de las obligaciones que como miembro de la sociedad internacional le incumben.

El problema surge de que en el Derecho deportivo las normas que rigen las federaciones nacionales e internacionales no han sido, hasta hace tan sólo unas décadas, conscientes del efecto publificador que en su normativa adquiere el hecho de que gestionen monopolísticamente una determinada disciplina deportiva y, por eso, la casuística y las excepciones no hacen de ninguna manera fácil la construcción de una doctrina clara acerca del tema.

En efecto, las disposiciones que recogen algunas federaciones internacionales en cuanto al acceso a la independencia de partes del territorio de un país en las que se admite la posibilidad de afiliación a países, regiones o naciones que no son Estados pero que estén en vías de adquirir la independencia, al margen de otras posibles interpretaciones, parece que buscan el establecimiento de un anticipo en el ámbito deportivo de algo que se va a producir como consecuencia de un cambio político inminente o, al menos, posible. Esta determinación por anticipación permite no romper el esquema de organización y constitución de las citadas entidades deportivas, que, como se ha visto, responden en esencia a un tipo de organización unitario y representado por las asociaciones nacionales, representadas, a estos efectos, de forma única en cada país.

El peligro de este tipo de disposiciones en los estatutos de las federaciones internacionales es que la aplicación incondicionada de un sistema excepcional supone una quiebra en el sistema de organización cuya consecuencia inmediata puede ser la presión de todos los territorios que están dotados de autogobierno de ser aceptado de una forma separada respecto del Estado al que pertenecen y están unidos.

Por otra parte y como veremos a continuación, la normativa de las federaciones internacionales aparece condicionada de forma implícita por la del Comité Olímpico Internacional, que ha marcado tradicionalmente las pautas y los criterios, al menos en las federaciones de deportes olímpicos, de admisión de países en distintas circunstancias y momentos históricos; por esta razón comenzamos describiendo los criterios de admisión en el COI, para poder entender posteriormente la influencia y las disposiciones de las federaciones deportivas internacionales. 


\section{LA REPRESENTACIÓN INTERNACIONAL EN EL ÁMBITO DE LOS JUEGOS Olímpicos. El COMITÉ OlÍMPICO InTERNACIONAL (COI) Y los Comités Olímpicos Nacionales}

En 1896, en Atenas, durante la sesión del 6 de abril, tendría lugar un cambio de dirección en la, hasta el momento, incipiente política de admisión de los distintos miembros en el seno del Comité Olímpico Internacional y supondría un cambio de rumbo en el hasta entonces joven Movimiento Olímpico. Durante la sesión, un miembro alemán del COI, el doctor Gerbhart, sugeriría la creación de Comités Olímpicos Nacionales fuertes con un carácter estable y definitivo. Estos Comités Olímpicos tendrían, entre otras, las funciones de enviar a los atletas a los Juegos Olímpicos y de esta forma se evitarían cargas económicas y administrativas adicionales al Comité Olímpico Internacional. Por tanto, cada país que tuviera la voluntad de participar en las Olimpiadas tendría como obligación la de dotarse de esta estructura. Si bien correspondería al COI reconocerla o no.

El COI entraba de esta forma en el gran tablero de las relaciones internacionales. Aparte de la Cruz Roja, fundada en 1863, en aquellos momentos, la organización olímpica no tenía ningún otro equivalente en el ámbito internacional. Permitiendo a los países afiliarse al Movimiento Olímpico, el COI pensaba reunir a la juventud mundial alrededor del acontecimiento olímpico y organizar de esta forma el deporte a escala internacional. Pero, al mismo tiempo, se daba una gran oportunidad a los países que formaban parte del Movimiento Olímpico, puesto que el ceremonial olímpico establecido en la Carta $^{5}$, con el desfile de las banderas de las naciones, sonando los himnos nacionales para celebrar las victorias, las camisetas de cada selección nacional, y la amplitud y magnificencia de éste, contribuirían a hacer de los Comités Olímpicos órganos deportivos claramente nacionales, o estatales.

En numerosas ocasiones, los Juegos Olímpicos han sido víctimas y rehenes de reivindicaciones y de una utilización desviada y corrompida de la imagen olímpica. Todo ello, a pesar de que la Carta Olímpica establece de forma clara que los Comités Olímpicos Nacionales deben preservar su autonomía y resistir a cualquier tipo de presión, ya sea de orden político, religioso o económico. Sin embargo, la historia olímpica nos muestra cómo es muy difícil, prácticamente imposible, llevar a cabo una disociación total de los Comités Olímpicos y sus respectivos países, y de sus propias reivindicaciones y relaciones exteriores con terceros países ${ }^{6}$.

5 Normas 69 y 70.

6 Además, debemos apuntar que la comprensión de la complejidad de lo que podríamos calificar como relaciones internacionales deportivas aumenta porque los Comités Olímpicos Nacionales, creados por los países/Estados/naciones, tienen muy distinto peso en el ámbito de su propia organización deportiva nacional. La diferencia en cuanto a su mayor o menor relevancia ad intra dependerá de la bifurcación o no que de las estructuras deportivas nacionales se haya realizado. Es decir, si la cúspide de la organización deportiva es el Comité 
De esta forma, el mundo olímpico participa de una doble naturaleza geopolítica. De una parte y en primer lugar, la naturaleza genuina y original del Comité Olímpico Internacional, cuyo principal objetivo es hacer participar a la humanidad de sus ideales mediante la admisión de los distintos países en su movimiento, y, de otra parte y en segundo lugar, el mundo olímpico muestra el comportamiento de las naciones, para las que los Juegos Olímpicos son de un interés determinante tanto en su política interior como exterior. Los Juegos Olímpicos son competiciones, y como tales suponen el enfrentamiento de atletas, de deportistas, pero sobre todo de países rivales deportivamente, pero que también lo pueden ser políticamente, y se aprovecha el escaparate olímpico para mostrarse y expresar su prestigio a través de las medallas obtenidas.

Es más, como certeramente apunta BARBA SÁNCHEZ ${ }^{7}$, a quien seguimos en este punto, las bases estructurales y operativas sobre las que se funda la organización olímpica gravitan en torno al Estado-nación, pues esta institución ha inspirado el sistema de incorporación de las estructuras deportivas y ha servido y sirve como modelo de representación deportiva en las competiciones olímpicas; asimismo, BARBA destaca cómo esta opción del Movimiento Olímpico por unos esquemas organizativos basados en lo «estatal», en lo «nacional», explica en gran medida su éxito e implantación a nivel mundial, y al relegar a otras entidades que planteaban fórmulas organizativas alternativas ha permitido al Movimiento Olímpico asumir un indiscutible protagonismo en la regulación de la práctica deportiva.

Los Juegos Olímpicos, como concluye el precitado autor, constituyen una plataforma ideal para construir o consolidar identidades nacionales, para intentar unificar naciones divididas, para reafirmar la centralidad o para mantener la legitimidad de ciertos Estados, y por ello no es de extrañar la pretensión, casi obsesiva, del Movimiento Olímpico por mantener absolutamente separado el mundo olímpico de la política, que tiene su reflejo en una pretendida (e imposible) independencia frente al mundo exterior, que se plasma normativamente en la Carta Olímpica.

La evolución del reconocimiento por el Comité Olímpico Internacional de los diferentes Comités Olímpicos Nacionales ha pasado por distintas fases, que a continuación analizaremos para estudiar los criterios de admisión de un Comité Olímpico Nacional, y que muestran la capacidad de adaptación del Movimiento Olímpico para absorber los cambios políticos

Olímpico o si existe una bicefalia, es decir, que, por una parte, la organización deportiva está estructurada a partir de las federaciones deportivas y un órgano con personalidad jurídica propia, como nuestro Consejo Superior de Deportes, y, por otra, el deporte olímpico se organiza a través del Comité Olímpico. Vid., en este sentido y sobre la naturaleza jurídica de los distintos Comités Olímpicos Nacionales: Francia y España, M. LoRA-TAmayo ValLVÉ, El derecho deportivo; entre el servicio público y el mercado, Ed. Dykinson, 2003, y "Nuevas perspectivas de la acción administrativa del deporte en Francia», RJD, núm. 10, 2003, págs. 165 y ss.; Italia, Estados Unidos y Alemania, R. BARBA SÁNCHEZ, «Los poderes públicos y el olimpismo», Revista Jurídica del Deporte, núm. 12, 2004, pág. 87.

7 R. BARba Sánchez, op . cit. En este punto cita a J. Macaloon, «Politics and the Olympics: Some new Dimensions» (http://diba.es/icps/working papers/docs/Wp_i_128.pdf). 
en la era moderna y las motivaciones deportivas, y sobre todo políticas, de afiliación al Movimiento Olímpico, y que tendrá como principal momento de inflexión el año 1996.

Por otra parte, analizaremos la lógica de comportamiento y el dinamismo que rigen en las relaciones entre las naciones y el Movimiento Olímpico explicado a partir de la descripción del mapa actual del olimpismo y las pretensiones de naciones que no son Estados de formar parte del mismo.

Por último y como señala HARGREAVES ${ }^{8}$, para entender la dinámica de la intervención de los Estados en el Movimiento Olímpico hay que tener en cuenta que existe una interacción de numerosos agentes para evitar que los Juegos Olímpicos pierdan su componente nacional, pues pese a que la competición olímpica apoya el internacionalismo, también alienta un nacionalismo (entendemos por nacionalismo aquí el de corte estatal, claro está) que los medios de comunicación se encargan de difundir, al retransmitir los Juegos bajo un prima estatal. De esta forma, los medios y la audiencia interactúan y están en connivencia en una construcción nacionalista de los Juegos, reforzando una cadena de intereses que opera como sigue: los medios de comunicación ${ }^{9}$, al retransmitir los eventos, construyen activamente los Juegos, les dotan de un sesgo nacional para evitar una caída de las audiencias; caída que provocaría una disminución de los anunciantes y sponsors; lo que a su vez reduciría la demanda de exposición en televisión; lo que secaría una de las fuentes de financiación de los Juegos y repercutiría sobre la propia organización olímpica.

\subsection{Principales funciones de los Comités Olímpicos Nacionales (CON). La inevitable politización y absorción por las estructuras administrativas-deportivas nacionales}

La que podríamos calificar como comunidad de Comités Olímpicos Nacionales se caracteriza, como apuntábamos anteriormente, por la existencia de una base o de unas funciones comunes establecidas en la Carta Olímpica, pero que podrán ser desarrolladas con los medios y la organización estructural del CON que cada "país olímpico» determine.

El artículo 31 de la Carta Olímpica establece que los Comités Olímpicos Nacionales tienen como principales funciones las de «propagar, desarrollarse y proteger el mensaje olímpico en sus respectivas naciones».

Las relaciones entre los CON y el COI son bastante estrechas, en tanto

8 J. HARgREAVES, Olympism and Nationalism: some preliminary considerations, Ponencia presentada en el Symposium Internacional sobre Juegos Olímpicos, Comunicación e Intercambios Culturales, Centro de Estudios Olímpicos, Universidad de Barcelona, 1991 (citado por BARBA SÁNCHEZ en «Los poderes públicos y el olimpismo», RJD, núm. 12, 2004).

9 Sobre la relación de los Juegos Olímpicos y medios de comunicación, vid. al respecto O. MARTín MuÑoz, "Los juegos olímpicos y la prensa, una relación necesaria», RJD, núm. 12,2004 , págs. 117 y ss. 
en cuanto el COI ejerce labores de orientación y dirección de los trabajos que los CON deban desarrollar ${ }^{10}$.

En principio, las relaciones entre los Comités Olímpicos Nacionales y toda entidad exterior al Movimiento Olímpico aparecen bien definidas en la Carta Olímpica y parece primar, como advertíamos anteriormente, el principio de apolitización de estas entidades. Pero la organización olímpica ha sido víctima de su propio éxito, y la ausencia de implicación política de los Comités Olímpicos Nacionales es una utopía desde el momento en que los Estados absorben esta organización como parte fundamental de su estructura administrativa, de su política deportiva, de forma que los Comités Olímpicos al integrarse en la organización administrativa, cuando despliegan sus efectos hacia el exterior, es decir, hacia fuera del ámbito de la competencia territorial estatal/nacional, están ejercitando la función pública de representación exterior del Estado.

En otras ocasiones la absorción de la estructura de los Comités Olímpicos es aún más burda y politizada, en el sentido de que es fagocitada por importantes personajes políticos del país y se utiliza siempre como herramienta política, sobre todo en África y Asia.

De cualquiera de las maneras, lo que está claro es que, a pesar de los pronunciamientos casi retóricos y utópicos de la Carta Olímpica, los Comités Olímpicos Nacionales se han convertido tanto en un instrumento de gestión y organización de la política deportiva dentro de un país como en un instrumento politizado de los territorios en sus luchas y sus reivindicaciones en el ámbito internacional.

Por tanto, esa limpia y casi naif separación de los poderes de los Comités Olímpicos Nacionales y los regímenes políticos es, hoy en día, pura especulación. El problema estriba, por tanto, en la utilización que se haga de ese poder político que reside en los Comités.

\subsection{La geografía olímpica y el problema del reconocimiento de los Comités Olímpicos Nacionales}

\subsubsection{Los continentes olimpicos. Excepciones.}

En poco más de un siglo, el Movimiento Olímpico ha adquirido una amplitud considerable. En la actualidad, 199 países olímpicos, repartidos

10 Los Comités Olímpicos Nacionales tienen, entre otras competencias, la capacidad de:

- Designar su ciudad candidata a la celebración de unos Juegos Olímpicos.

- Desempeñar una importante relación con las federaciones nacionales olímpicas y no olímpicas y admitirlas o no como miembros de la organización del Comité.

- Ejercer de forma exclusiva la competencia para seleccionar la delegación de atletas que acudirán a los Juegos Olímpicos, con la proposición de las federaciones nacionales.

De estas tres funciones de los Comités Olímpicos Nacionales interesa analizar la evolución de la tercera de dichas funciones. 
por los cinco continentes, muestran su faceta internacional de forma clara. Desde los más potentes a los más débiles, casi la totalidad de la humanidad se encuentra adherida a los ideales olímpicos. Desde 1894 los países han ido adhiriéndose progresivamente al Movimiento Olímpico, para formar en torno al Comité Olímpico Internacional una de las más importantes organizaciones internacionales no gubernamentales en términos de países afiliados.

La pertenencia a las Asociaciones de Comités Olímpicos por continentes reconocidas así en la Carta Olímpica (art. 4.2) tiene algunas excepciones debidas a factores históricos y políticos.

Existen cinco organizaciones continentales que agrupan a los Comités Olímpicos de cada uno de ellos: la Asociación de Comités Nacionales Olímpicos de África, la Federación Olímpica de Asia, la Asociación de Comités Olímpicos Nacionales en la que se agrupan los Comités Olímpicos Europeos, la Organización Deportiva Panamérica y los Comités Olímpicos Nacionales de Oceanía. En principio, estas asociaciones tienen una correspondencia geográfica clara, pertenecerán a cada Comité continental del Comité Nacional del continente al que pertenezcan; sin embargo, existen algunas excepciones fundadas en razones históricas o políticas ${ }^{11}$.

\subsubsection{El reconocimiento de los Comités Olímpicos Nacionales. Criterios.}

El Movimiento Olímpico tiene su propia geografía, que es muestra de su peso político; si consideramos que el número de países afiliados es sinónimo de su fuerza o de su importancia, podemos considerar al Comité Olímpico Internacional, con 199 países miembros, como un organismo internacional de primer orden. La Organización de Naciones Unidas (ONU), organización internacional por excelencia, no reconoce más que 189 Estados miembros.

Esta diferencia se explica por el hecho de que, durante un largo periodo de tiempo, el Comité Olímpico Internacional aplicó una forma de reconocimiento que era independiente de consideraciones políticas. Sin embargo, el

11 Rusia, por ejemplo, se localiza históricamente en Europa, aunque la mayor parte de su territorio pertenezca a Asia. La orientación occidental de las grandes ciudades rusas hace que el Comité Olímpico Nacional Ruso esté orientado hacia el Oeste.

Indonesia ha desarrollado un comportamiento similar; es un gran país a caballo entre dos continentes (Asia y Oceanía) y que en los últimos años ha estrechado sus relaciones comerciales con sus vecinos asiáticos y se ha integrado en el OCA (Olympic Council of Asia).

La posición de Turquía es reflejo de esta dislocación geográfica y política, ya que si bien su territorio es más asiático que europeo, sus relaciones políticas y económicas son más estrechas con Europa.

El caso de Israel es ciertamente singular, pues a pesar de estar alejado geográficamente de Europa, lo está más, desde una perspectiva diplomática, con sus más cercanos vecinos. Los conflictos incesantes por el territorio palestino han conducido a un enfrentamiento constante de Israel con el Líbano, Siria, Egipto y los países árabes tras la segunda guerra mundial. Por el propio origen de su población, y los conflictos internacionales que genera en su entorno, Israel pertenece al Comité Olímpico Europeo. 
COI se dio cuenta de que el reconocimiento de un país o Estado olímpico mediante el reconocimiento de la existencia de su respectivo Comité Olímpico Nacional podía suponer un escaparate de reivindicaciones políticas sistemáticas que ponían en peligro la tan ansiada neutralidad del Comité Olímpico Internacional y del Movimiento Olímpico. Por esta razón, para proteger su naturaleza apolítica, el COI ha debido cambiar sus reglas de reconocimiento. De lo que resulta una geografía olímpica original ya que para su establecimiento se han tenido en cuenta dos lógicas o sistemas diferentes de reconocimiento.

El COI se reserva el derecho de reconocer a los Comités Olímpicos Nacionales con el objetivo de promover el Movimiento Olímpico en el mundo (art. 4.1 de la Carta Olímpica). El país candidato al afiliarse al Movimiento Olímpico debe realizar su petición. El futuro Comité Olímpico Nacional deberá acatar la Carta Olímpica. La admisión o no de un candidato se fundamenta en dos criterios, uno deportivo y otro jurídico.

a) Criterio deportivo: existencia de una presencia deportiva mínima.

Cada candidato debe tener una presencia deportiva mínima de cinco federaciones nacionales afiliadas a las federaciones internacionales de deportes olímpicos para poder ser admitido, conforme a lo establecido en el artículo 32.1.2 de la Carta Olímpica. La actividad deportiva de estas federaciones debe ser real y específica tanto en su país como en el ámbito internacional, y tienen por obligación la organización y/o participación en campeonatos internacionales. Esta cláusula tiene por objetivo la necesidad de que los países candidatos demuestren su desarrollo deportivo y la existencia de una organización deportiva con capacidad suficiente no sólo de participación, sino también de organización, y evitar de esta manera la posible aceptación de Comités Olímpicos Nacionales ficticios y demostrar así la existencia de una verdadera estructura deportiva independientemente del nivel deportivo, mejor o peor, que puedan o hayan podido demostrar los deportistas en el ámbito internacional. El requisito deportivo es, pues, una exigencia de capacidad de organización y participación, pero no de excelencia o calidad deportivas.

Por lo tanto, el mínimo exigible y exigido por el COI permite, en principio, a países con una escasa organización deportiva su participación en el ideal y en el Movimiento Olímpico.

Los principales factores causantes de las diferencias entre los Comités Olímpicos Nacionales con cinco federaciones afiliadas y aquellos que tienen las 28 federaciones son de índole económica, geográfica, demográfica, política e histórica.

La tradicional división económica Norte-Sur tiene también su reflejo en la mayor fortaleza de los CON del Norte (entendiendo por éstos los CON que tengan más de cinco federaciones internacionales afiliadas).

Por otra parte, el factor de la extensión geográfica es independiente del 
nivel económico del Estado. Los micro-Estados, los países pequeños en Europa, Asia o América tienen un peso inferior.

El factor demográfico no es decisivo en tanto en cuanto hay Comités Olímpicos de países muy poblados que no tienen un alto grado de afiliación, lo que muestra que este factor no es determinante; así, China o la India están afiliados a las 28 federaciones internacionales; sin embargo, Indonesia o Nigeria no lo están.

La aparición de un Comité Olímpico Nacional fuerte (entendiendo por tal aquel que goza de un alto número de federaciones internacionales afiliadas) puede explicarse en algunos casos por razones históricas; así, por ejemplo, el peso o el legado de la colonización y su herencia en el ámbito deportivo, como muestra el alto número de afiliaciones en países como Sudáfrica, la India o Cuba.

Desde esta misma perspectiva histórica, el mayor peso de los Comités Olímpicos Nacionales en el seno del COI deberían tenerlo aquellos países cuya afiliación se produjo en un momento más temprano; sin embargo, esta premisa no siempre es cierta, puesto que algunos Comités Olímpicos, especialmente los africanos, surgidos hace más de medio siglo (se afiliaron en su mayoría entre 1945 y 1970), no han adquirido el nivel de los CON europeos y, por el contrario, la mayor parte de los países surgidos de la desintegración del bloque comunista en 1991 se han encontrado de forma muy rápida en la clase superior o más potente de los $\mathrm{CON}$, puesto que se han beneficiado del peso y la tradición deportiva soviéticos, cuyas estructuras han nacionalizado e internacionalizado al elevarlas al nivel olímpico.

Paralelamente, la inestabilidad política y económica es un factor diferenciador de los Comités Olímpicos Nacionales; así, las Repúblicas de la antigua Yugoslavia o de la antigua Unión Soviética, de reciente creación, son bastante inestables, a pesar del legado estructural deportivo tan fuerte que se dejó en estos países.

El resultado de esta distribución que tantas diferencias presenta es también fruto del mayor o menos interés cultural que ofrecen las distintas prácticas deportivas en cada uno de los países, y que responden a razones muchas veces culturales, sociológicas o incluso climatológicas.

Desde una perspectiva deportiva, strictu sensu los deportes más extendidos son los deportes colectivos, por una parte: el voleibol, fútbol y baloncesto, y el atletismo, que queda como el deporte fundamental, o la actividad física esencial, y la más barata, claro está (todos podemos tener en la cabeza la imagen de los deportistas kenyanos batiendo récords del mundo en grandes distancias).

De toda esta clasificación y, al mismo tiempo, relativización del criterio deportivo se desprende que éste funciona como un mínimo indispensable, pero el verdadero criterio de afiliación o de reconocimiento de un Comité Olímpico Nacional es de carácter político y jurídico. 
b) Criterio jurídico-político. Estado, país y territorio olímpico.

- La redacción original del artículo 34. La geografía deportiva.

Con el fin de que el Comité Olímpico Internacional reconozca e incorpore en su organización a un Comité Olímpico Nacional, el candidato debe probar su existencia y su legitimidad como país.

Esta cláusula es, sin duda alguna, el punto crucial de la representatividad olímpica. Mediante la definición de lo que considera como país, el COI ha intentado preservar el control de la composición de su movimiento respetando los principios fundamentales del olimpismo.

En este sentido y en los inicios de la era moderna de los JJ.OO., el COI se desmarcó de la naturaleza política de los Estados haciendo suya la postura de Coubertin, quien argumentaba que la geografía deportiva podría ser diferente de la geografía política; reflexión ésta que se inscribe, lógicamente, en los viejos valores del olimpismo y en la lógica geográfica de su época, tomada de las teorías de la geografía francesa del siglo XIX ${ }^{12}$.

Estas teorías parten de una concepción atomizada de la definición del territorio que no era del todo ilógica en la época en la medida en que existían en aquellos momentos grandes imperios, como el austro-húngaro ${ }^{13} \mathrm{o}$ la propia Rusia, que estaban compuestos por distintos países y a los que se pretendía dar cabida en el ámbito olímpico de forma independiente, reconociendo, en cierta medida, sus orígenes diferentes.

La utilización del término país fue cayendo en desuso de forma progresiva. Con la descolonización y la caída del imperio austro-húngaro, los Estados son cada vez más numerosos y era necesario que el COI definiera o, al menos, precisara un poco más la idea que tenía del término "país», pero estas precisiones no llegarían hasta 1996 y es lo que permitió que, hasta esta reciente fecha, la geografía olímpica no coincida de forma exacta con la geografía política, la que identifica países con Estados.

Hasta 1996, el COI se reservaba el derecho de reconocer a los Comités Olímpicos Nacionales con base al siguiente criterio: «un Estado, un territorio o porción de territorio que el COI considere según su decisión discrecional, y como una zona de jurisdicción de un país que haya reconocido». Posteriormente a la redacción original y algo vaga de este concepto se añadió, a principios de los años sesenta, una primera precisión a la redacción original del artículo, en el que se añadía que, teniendo en cuenta que el Movimiento Olímpico es apolítico, los términos «país» o «nación» que se dan en estas reglas se aplicarían igualmente a una noción geográfica, zona o territorio en los límites en los que un Comité Olímpico reconocido por el COI desplie-

12 A. Chauprade, Introduction à l'analyse géopolitique, Ellipses, Paris, 1999. Cita a VIDAL DE LA BLACHE, que define país como «una pequeña patria de horizontes multiformes, donde el paisaje es monótono y aparece enmarcado en todos sus recodos por obras humanas similares».

13 Vid. en este sentido F. Sosa Wagner e I. Sosa Mayor, El Estado fragmentado. Modelo austro-húngaro y brote de naciones en España, Ed. Trotta, Madrid, 2006. 
gue su actividad o funcione ${ }^{14}$. Esta necesidad de justificar la utilización de la noción de «país» demostraba ya que el COI se había visto en la situación de llevar a cabo interpretaciones aproximativas y de relevancia política internacional y no sólo deportiva.

\section{- La nueva redacción del artículo 34.1 de la Carta Olímpica.}

Desde el inicio de la era moderna de los Juegos Olímpicos, muchos países han ido solicitando el reconocimiento del Comité Olímpico Internacional. El COI, con mayores o menores dificultades, ha ido resolviendo caso a caso y las solicitudes para ingresar en el Movimiento Olímpico se incrementaron de forma extraordinaria a partir de 1990.

La caída del Muro de Berlín produjo un efecto dominó y la llamada de las antiguas Repúblicas soviéticas y de la antigua Yugoslavia a la puerta del Movimiento Olímpico, incluso antes de declararse su independencia, provocó la reforma del artículo 34.1 de la Carta Olímpica.

La razón principal era que el COI se estaba convirtiendo, sin pretenderlo, en un primer interlocutor de aquellos países o Estados que ansiaban una independencia, todavía no reconocida internacionalmente, y el reconocimiento de un Comité Olímpico Nacional equivaldría o probaría la existencia de ese país en el escenario internacional, lo que planteó un problema de posicionamiento político al COI. ¿Debía ser este reconocimiento previo o posterior al reconocimiento internacional de los Estados?

El COI, lógica y coherentemente, manifestó que la anticipación al reconocimiento internacional de la admisión de un Comité Olímpico Nacional supondría, qué duda cabe, un cambio en la naturaleza misma del COI, que pasaría a ser una organización internacional de carácter político, contraviniendo así su propia esencia y razón de ser. Por esta razón y con el objetivo de proteger el Movimiento Olímpico, se decidió cambiar la regla de reconocimiento de los Comités Olímpicos Nacionales.

A partir de este momento, el artículo 34.1 especifica que país significa «un Estado independiente reconocido por la Comunidad internacional», por lo que la concepción geográfica de país se transforma en una concepción sociojurídica en la que la noción de independencia y soberanía es fundamental.

En efecto, la autoridad olímpica se apoya en la opinión de la comunidad internacional para pronunciarse acerca de la noción de independencia y legitimidad de un Estado, de forma que evita dar su propio punto de vista acerca de lo que concibe como «reconocimiento por la Comunidad internacional».

De esta forma, el COI se muestra muy precavido en tanto en cuanto desplaza el acto jurídico del reconocimiento a un acto político previo que no le corresponde hacer, o al menos no le corresponde de forma unilateral y previa al del resto de la comunidad internacional, pues tampoco especifica el orga-

14 Cfr. O. MAYER, A travers les anneaux olímpiques, Cailler, Genève, 1960. 
nismo que haya de hacer de forma previa este reconocimiento; pudiera ser la ONE, la Unión Europea, la OCDE o la OMC (Organización Mundial del Comercio); de esta forma, el COI adopta una postura que le permite un cierto margen de maniobra, y se espera a la obtención por parte del país candidato de un reconocimiento internacional de peso.

\section{LA REPRESENTACIÓN INTERNACIONAL EN EL ÁMBITO DE LAS FEDERACIONES INTERNACIONALES}

Los criterios de admisión de las federaciones internacionales están sometidos, en su mayor parte, a lo establecido en la Carta Olímpica.

En principio, gran número de federaciones internacionales lo son de deportes olímpicos; por esta razón, sus estatutos se remiten de forma subsidiaria a la regulación de lo que la Carta Olímpica establezca y la representación internacional se regirá, por tanto, por lo dispuesto en el artículo 34.1 de la Carta Olímpica.

Sin embargo, la diferencia que hay entre el número de federaciones internacionales existentes en relación con el número de Estados ${ }^{15}$ es mayor que con los Comités Olímpicos Nacionales, lo que nos conduce a la cuestión de si las federaciones internacionales son, en cierto sentido, productoras de nuevos espacios o nuevos territorios deportivos.

En este sentido, CHAMERoIs ${ }^{16}$ lleva a cabo una justificación de las razones que conducen a algunas federaciones internacionales a llevar a cabo este tipo de reconocimientos, y entiende que una de las razones que puede concurrir para obtener el mayor número de afiliación de federaciones internacionales posible (sin distinguir si éstas responden a una estructura nacional previa o no) es lograr la reivindicación de ser «deporte número 1 mundial» 17 .

Las pretensiones de reconocimiento de federaciones internacionales de países que no son Estados tienen distintas causas, pero una de ellas, como analizaremos a continuación para el caso catalán, es lograr la obtención de cinco federaciones internacionales, para así, al menos, cubrir el requisito deportivo que la Carta Olímpica exige para poder obtener su propio Comité Olímpico Nacional.

Un gran número de federaciones internacionales, desde la reforma de la Carta Olímpica, han procedido en su mayor parte a reformar sus estatutos

15 Vid. al respecto N. Chamerois, The Globalisation of the Olympic Games. From Seoul (1988) to Sydney (2000), Thése de Doctorat, CERSO, Univerité Franche-Comté, 2002.

16 Ibidem.

17 En este sentido, el caso de la Federación Internacional de Voleibol es significativo puesto que se encuentran afiliados 218 países, o federaciones internacionales, frente a los 199 Comités Olímpicos Nacionales reconocidos y los 191 Estados independientes reconocidos por la ONU. Mediante el reconocimiento de federaciones internacionales se estaba creando una nueva geografía deportiva. 
para precisar la identificación país con Estado-nación reconocido por la comunidad internacional ${ }^{18}$.

\section{El caso español. Antecedentes, problemática, ¿PERSPECTIVAS DE FUTURO?}

El problema de la representación internacional de las federaciones y selecciones deportivas autonómicas trasciende no sólo del ámbito estricta-

18 - Federación Internacional de Pelota Vasca. Sus Estatutos provienen de 1948, y en el artículo 4 se establece que «en el seno de la FIVP sólo podrá existir una Federación por Nación, no admitiéndose por parte de países ya representados, aunque se solicite con nombre distinto...».

- Unión Europea de Karate. La norma estatutaria procede de 1996, y en el artículo 4. ${ }^{\circ}$ de la misma se establece expresamente que «pueden afiliarse a la Unión Europea de Karate las Federaciones nacionales de Karate de cualquier país europeo cuyo Comité Olímpico esté reconocido por el Comité Olímpico Internacional. Sólo se permite una Federación Nacional por país, en concreto, aquella reconocida por el Comité Olímpico Nacional o, en su caso, por la más alta autoridad deportiva del país en cuestión...».

- Federación Internacional de Motociclismo. Sus Estatutos datan de 1998, que en su apartado 2.21.21 establecen que «todas las naciones del mundo pueden estar representadas en la FIM pero solo una Federación u organización nacional...».

- Federación Internacional de Automovilismo. Sus Estatutos se aprueban en 1997 y señalan, en el artículo 3. ${ }^{\circ}$, que la afiliación se corresponde con el principio de «uno solo por país...».

- Federación Internacional de Baloncesto. Sus Estatutos, tras la reforma de 1998, establecen, en el artículo 6. ${ }^{\circ}$, que "podrán ser miembros de la FIBA toda Federación Nacional de Baloncesto independiente. Por nacional debe entenderse que su ejercicio está autorizado en un territorio claramente determinado geográficamente... Una sola Federación Nacional de Baloncesto puede ser reconocida por la FIBA en un país o territorio...».

- Federación Internacional de Esquí. Sus Estatutos, que datan de 1996, parten, en el artículo $6 .^{\circ}$, de la consideración de que sólo una organización de esquí puede convertirse en miembro de la FIS, normalmente bajo el nombre por el cual es conocida en su propio país.

- Unión Ciclista Internacional. Los Estatutos, aprobados en 1993, parten, en su artículo $4 .^{\circ}$, de la consideración de que los miembros de la UCI son las Federaciones Nacionales de Ciclismo.

- Federación Internacional de Gimnasia. Sus Estatutos, tras la reforma de 1997, indican en su artículo $1 .^{\circ}$ que «la Federación Internacional de Gimnasia está constituida por las Federaciones Nacionales afiliadas y reconocidas como órganos que controlan la Gimnasia en sus respectivos países». La FIG no reconoce nada más que una Federación por país.

- Federación Internacional de Balonmano. Tras la reforma de sus Estatutos de 1998, el artículo 3.2 de los mismos determina que sólo se podrá admitir como miembro de pleno derecho a una organización por país y debe recaer en las que controlan el balonmano en sus respectivos Estados.

- Federación Internacional de Tiro. Sus Estatutos, en la redacción dada en 1993, determinan en el artículo 3 que la afiliación se admite para una Federación por país.

- Federación Internacional de Piragüismo. Sus Estatutos, de 1993, indicaban ya que serán miembros de la ICF aquellas federaciones nacionales que hayan sido aprobadas por el Congreso. Para ser miembros deben aportar un certificado de su Comité Olímpico o de la autoridad deportiva más alta en el que se afirme que la Federación Nacional está reconocida como institución de control a nivel del Estado.

- Federación Internacional de Remo. Sus Estatutos, de 1993, establecen de una forma contundente, en el artículo 9, que sólo una Federación Nacional que haya reunido a la mayoría de los clubes de su país y que haya sido reconocida como tal por una organización su- 
mente deportivo, sino también del jurídico, y es utilizado por los partidos nacionalistas como arma arrojadiza de fuerte impacto social y, claro está, mediático ${ }^{19}$.

La implementación jurídica de este tipo de reivindicaciones no se hizo esperar y las Comunidades Autónomas del País Vasco y Cataluña han formulado en sus respectivas legislaciones autonómicas del deporte principios de representación internacional única.

Por otra parte, y en sede jurisprudencial, han intentado desvincularse de la necesaria autorización estatal requerida para permitir la participación de selecciones autonómicas en acontecimientos deportivos internacionales prevista en la legislación estatal del deporte.

Sin embargo, llama la atención cómo el recientemente aprobado Estatuto de Cataluña (Ley Orgánica 6/2006, de 19 de julio, de reforma del Estatuto de Autonomía de Cataluña) se retranquea, en cierta medida, con respecto a los pronunciamientos realizados en la Ley del Deporte catalán, quizá porque, tal y como hemos descrito, las organizaciones deportivas internacionales no parecen estar dispuestas, al menos de momento, a hacer de España una nueva excepción que rompa con el rentabilísimo modelo estatal-nacional impuesto desde el COI y las federaciones internacionales deportivas.

Ante la escasa probabilidad de éxito, algunas instituciones deportivas continúan presionando políticamente, mediante lo que hemos calificado como la "vía de hecho», que ha tenido distintas manifestaciones, como fue el caso del hockey o, en la actualidad, el del fútbol sala.

\subsection{El problema legislativo. Las leyes autonómicas del deporte y la representación internacional}

La delimitación competencial en el ámbito del deporte implica la necesaria existencia de una serie de medidas de coordinación entre la Administración del Estado y las Comunidades Autónomas para el ejercicio de aquellas competencias que puedan afectar directa y manifiestamente a los intereses generales del deporte en el ámbito nacional. Este principio gene-

prema de deportes o por su Comité Olímpico Nacional. Para estar afiliado como miembro de la FISA, una Federación debe cubrir el territorio de un país reconocido como tal y estar reconocido como Estado soberano e independiente por la comunidad internacional.

- Federación Internacional de Judo. Sus Estatutos, desde 1997, determinan que cada país podrá estar representado en su Unión Continental por una sola Federación Nacional.

- Federación Internacional de Hockey. Sus Estatutos, tras la reforma de 1998, establecen que la asociación corresponde únicamente a países que se configuran en una lista cerrada, en la que no se encuentra incluido Gibraltar.

- Federación Internacional de Vela. Tras la reforma de sus Estatutos de 1998 admite como miembros de pleno derecho a los que sean reconocidos por la autoridad nacional.

19 En este sentido destaca la denominada "Declaración de Barcelona», en la que los partidos nacionalistas firmantes consideran que «el reconocimiento simbólico de la plurinacionalidad del Estado español pasa ineludiblemente por la creación y aceptación de selecciones nacionales deportivas por las diferentes naciones del Estado». 
ral, que manifiesta la Ley del Deporte en su Exposición de Motivos, se materializa de forma expresa en el artículo 2 de la Ley, en el que se establece que la Administración del Estado «coordinará con las Comunidades Autónomas y, en su caso, con las corporaciones locales aquellas [competencias] que puedan afectar directa y manifiestamente a los intereses generales del deporte en el ámbito nacional».

Partiendo de este principio general y aunque, como indica ARNALDO ALCUBILLA $^{20}$, las referencias legales son dispersas, en el ámbito internacional el principio de coordinación se traduce en diferentes intervenciones.

De una parte, el artículo 8.i) de la Ley del Deporte establece que el Consejo Superior de Deportes podrá «autorizar o denegar previa conformidad del Ministerio de Asuntos Exteriores, la celebración en territorio español de competiciones deportivas oficiales de carácter internacional, así como la participación de las selecciones españolas en las competiciones internacionales».

De otra parte, el artículo 6.p) establece la competencia del Consejo Superior de Deportes para autorizar la inscripción de las federaciones deportivas españolas en las correspondientes federaciones deportivas de carácter internacional. Y, además, es a las federaciones deportivas españolas a las que corresponde "organizar o tutelar las competiciones oficiales de carácter internacional que se celebren en el territorio del Estado", así como "ostentar la representación de España en las actividades y competiciones deportivas de carácter internacional así como la elección de los deportistas que hayan de integrar las selecciones nacionales».

El desarrollo reglamentario de esta normativa dispersa referente a la representación internacional ha sido realizado por el Real Decreto 2075/1982, de 9 de julio, sobre Actividades y Representaciones Deportivas Internacionales $^{21}$.

El Real Decreto 2075/1982 22 regula la participación española en confrontaciones deportivas internacionales (capítulo I), la representación española en federaciones y otros organismos deportivos internacionales (capítulo II), la organización de asambleas o reuniones internacionales de carácter deportivo en territorio español (capítulo III) y la financiación de las actividades y representaciones a las que se refiere el Real Decreto (capítulo IV).

La participación española en confrontaciones deportivas internaciona-

20 E. Arnaldo Alcubilla, «El ámbito de participación de las selecciones deportivas autonómicas en competiciones deportivas internacionales», Actualidad Jurídica Aranzadi, año IX, núm. 383, 25 de marzo de 1999.

21 El citado Real Decreto es un Reglamento ejecutivo de la Ley 13/1980, de 31 de marzo, General de la Cultura Física y el Deporte, que, a pesar de haber sido derogada expresamente por la actual Ley 10/1990, de 15 de octubre, del Deporte, mientras no exista el desarrollo reglamentario necesario de la «nueva» Ley, se podrá considerar vigente en la medida en que sus disposiciones no sean incompatibles con la actual norma.

22 Vid., al respecto, A. LuEngo Álvarez-SANTulLANO, «Acerca del Real Decreto 2075/1982 sobre actividades y representaciones deportivas internacionales», Revista Española de Derecho Deportivo, núm. 4, 1994; F.-X. Pons RAFOls, «El COI y los Juegos Olímpicos: algunas cuestiones de relevancia jurídico-internacional», Revista Española de Derecho Internacional, vol. XLV, núm. 2, 1993. 
les, desarrolladas o no en territorio nacional, está sometida al cumplimiento de una serie de requisitos previos ${ }^{23}$ que condicionarán el otorgamiento de la respectiva autorización administrativa proveniente del Consejo Superior de Deportes y de la conformidad previa del Ministerio de Asuntos Exteriores.

Por otra parte, el artículo 4 establece la prohibición expresa de autorizar competiciones internacionales con selecciones de otros países si la representación española no se estableciese igualmente como categoría de selección nacional ${ }^{24}$.

En cuanto a la representación española en federaciones y otros organismos deportivos internacionales, el Real Decreto 2075/1982 establece de forma clara que únicamente podrá ser la que el Gobierno de la Nación haya nombrado, a propuesta del Consejo Superior de Deportes, o bien aquella que haya designado el organismo internacional del que España sea parte, cuando así lo establezcan sus reglas constitutivas. Existen algunas excepciones al reconocimiento exclusivo de los organismos designados por el Gobierno en condiciones especiales y sometidos a una serie de requisitos previstos en el artículo 7, que son de índole organizativa y política. Por una parte, se admitirá esta representación cuando ésta corresponda a las federaciones legalmente constituidas o se encuentren inscritas en secciones o comités de algunas federaciones epañolas existentes, si bien la iniciativa para la designación de la representación española debe partir de la correspondiente Federación Española, sin que puedan ser reconocidas por el CSD las representaciones que partan de iniciativas independientes de la indicada ${ }^{25}$.

Como requisito de carácter político se establece que el organismo o federación internacional no practique ningún tipo de discriminación respecto de la correspondiente modalidad deportiva española.

23 El artículo 2 establece como requisito previo que la participación de que se trate deba estar incluida en el programa general aprobado por la Asamblea o Junta de Gobierno de la Federación respectiva, para cada año o temporada, y tratándose de clubes el requisito será el mismo pero habrá de contar, además, con el informe favorable, se supone que preceptivo, de la respectiva Federación —ap. b)—. Además, las confrontaciones internacionales, oficiales o no, deberán haber sido autorizadas por la Federación Internacional correspondiente y, en todo caso, se acreditará que la celebración de la respectiva confrontación internacional se haya puesto en conocimiento previo de la Federación Internacional correspondiente y que ésta no haya manifestado su disconformidad transcurrido el plazo de quince días, a contar desde la comunicación.

${ }^{24}$ La problemática de este artículo la analizaremos a continuación a propósito de la Federación Vasca de Surf y el problema de la posible integración de las federaciones deportivas autonómicas en las federaciones internacionales en los casos en que no exista federación española ni selección nacional que pueda representar a España.

25 El procedimiento para su reconocimiento de la representación española aparece regulado en el artículo 8, que establece: «la federación respectiva comunicará al CSD, con carácter previo a la designación del representante o representantes, los nombres o circunstancias personales de los candidatos. A la vista de la información practicada por el Consejo, éste hará expresa su conformidad o disconformidad y lo comunicará a la federación o federaciones. Si la representación española resultara de propuesta directa de la correspondiente federación u organismo internacional, como consecuencia de elección o designación en el seno de la misma, el CSD reconocerá la representación propuesta». 
El problema competencial que emana de estas disposiciones ha surgido de la regulación que las legislaciones catalana y vasca del deporte realizan respecto de la representación internacional de sus respectivas Comunidades Autónomas, y que la jurisprudencia de los Tribunales Superiores de Justicia, del Tribunal Supremo y del Tribunal Constitucional ha intentado, y en algún caso está intentando todavía, solventar.

La polémica regulación emana, como habíamos advertido, de la Ley 14/1998, de 11 de junio, del Deporte del País Vasco, en cuyo artículo 16.6, fruto de una enmienda pactada entre PNV, EA y HB, se establece que «la federación vasca de cada modalidad deportiva será la única representante del deporte federado vasco en el ámbito estatal e internacional». Y, de otra parte, el Decreto Legislativo 1/2000, de 31 de julio, Texto Refundido de la Ley del Deporte de Cataluña, que se aprueba bajo la denominación de «texto único de la ley del deporte», en el que se refunden la Ley 8/1988, de 7 de abril, y la Ley 8/1999, de 30 de julio, y la Ley 9/1999, de 30 de julio, establece en su artículo 19.2 que las federaciones catalanas de cada modalidad son las representantes del respectivo deporte federado catalán en los ámbitos suprautonómicos y tienen como función propia la creación, fomento e impulso de las selecciones catalanas de las respectivas modalidades o disciplinas deportivas con la finalidad de participar en acontecimientos de cualquier ámbito oficial o amistoso, según proceda. Los artículos 25 y 26 de la Ley catalana establecen, asimismo, la regulación de las actividades deportivas catalanas de ámbito autonómico y suprautonómico, estableciendo los requisitos de composición de las selecciones catalanas, estableciendo una conexión, por razones históricas, culturales y deportivas, entre los «países» de lengua catalana, promoviendo selecciones conjuntas e integradas.

\subsection{Controversia y problema competencial en sede jurisdiccional}

La aprobación de estos preceptos autonómicos, así como la regulación estatal del Real Decreto 2075/1982, de 9 de julio, no han estado exentas de polémica y han sido fruto de diferentes pronunciamientos jurisprudenciales. La cuestión de las selecciones catalanas y vascas se encuentra sub judice y sus preceptos suspendidos con base a dos autos del Tribunal Constitucional. Un tercer problema que se ha suscitado en sede jurisdiccional ha sido el intento de reconocimiento de Cataluña como "país olímpico", que ha sido objeto de una sentencia del Tribunal Superior de Justicia de Cataluña y otra del Tribunal Supremo.

La primera sentencia que intenta poner un poco de orden en esta espinosa materia viene de la mano del Tribunal Constitucional. La STC 1/1986, de 10 de enero, resuelve un conflicto positivo de competencias promovido por el Consejo Ejecutivo de la Generalidad de Cataluña contra el Real Decreto 2075/1982, y en concreto contra el artículo 4, en conexión con los artículos 1,3 y 5. 
El artículo 4 del RD 2075/1982 establece que «no se autorizarán en ningún caso competiciones internacionales de las comprendidas en este Capitulo, con selecciones nacionales de otros países, si la representación española no se estableciese igualmente con categoría de selección nacional». La sentencia no encuentra vicio de inconstitucionalidad alguno en este precepto y fundamenta el fallo con dos argumentos básicos:

1) De una parte, entiende que "es posible de conformidad con nuestro ordenamiento jurídico, una intervención en encuentros internacionales de las federaciones deportivas cuyo ámbito propio se extienda al territorio de una Comunidad Autónoma», lo que no priva, por tanto, la representación o intervención internacional de las selecciones autonómicas, siempre que no lo haga la Federación Española de la misma especialidad deportiva y previa autorización de ésta.

2) El segundo argumento, que se refiere a la autorización administrativa emanada del CSD y del Ministerio de Asuntos Exteriores para legitimar la participación de las federaciones autonómicas en competiciones de carácter internacional, establece que «desde el momento en que la decisión sobre la participación ha adquirido rango nacional, por haberse pronunciado la federación española correspondiente, es claro que la posible intervención administrativa que aquí se viene considerando no puede corresponder a las autoridades de la Comunidad autónoma, pues si éstas tienen, sin duda, competencias en materia deportiva, con arreglo a su Estatuto de Autonomía, no es menos cierto que esas competencias, como cualesquiera otras de las que ostente, no pueden desplegarse sobre entes que existen y desarrollan sus actividades en un ámbito nacional, sustraído ya al ejercicio de las potestades autonómicas, estando la autonomía constitucionalmente garantizada a las CC.AA. al servicio de la gestión de sus intereses propios (art. 137 CE), limitados "ratione loci" (art. 25 del Estatuto de Autonomía de Cataluña) y no siendo desde ella posible, ciertamente, la afectación como aquí habría de ocurrir, de intereses que son propios del deporte federado español en su conjunto. Así autorizada por una federación española la comparecencia internacional de una de las federaciones catalanas que en ella se integran, no puede reclamar la generalidad, como competencia propia, la de sujetar su intervención administrativa ulterior, ratificándola o no, a aquella autorización federativa».

En definitiva, la jurisprudencia constitucional, en un primer momento, reconoce la proyección internacional de las federaciones deportivas autonómicas y que su participación en competiciones deportivas internacionales queda limitada a encuentros amistosos, es decir, de carácter no oficial, y a aquellos de carácter oficial en los que no exista Federación Española de la correspondiente modalidad deportiva o en los que no participen selecciones nacionales de otros países.

Parece que la cuestión, al menos en este primer embate, queda zanjada, aunque, como veremos, las Comunidades Autónomas vasca y catalana persisten en su intento de implantar un modelo de representación interna- 
cional deportiva «a la inglesa», y, así, en esta primera resolución el Tribunal Constitucional parece dejar claro en principio que la proyección internacional inherente a las competiciones deportivas internacionales justifica la intervención del Estado, por cuanto en ellas se expresa de manera patente el Estado mismo, a través de la participación de sus deportistas nacionales, de forma que son las selecciones nacionales las que representan al deporte nacional y las selecciones autonómicas las que representan al deporte regional, por lo que en principio la participación en competiciones deportivas internacionales de selecciones autonómicas sólo será posible siempre que en las mismas no intervenga la selección nacional española.

Esta primera resolución del Tribunal Constitucional no ha dejado, sin embargo, zanjada la cuestión, como era de esperar; las reivindicaciones nacionalistas persiguen el reconocimiento de sus selecciones a nivel internacional porque supondría un reconocimiento cuasi-oficial a su ansiada independencia; ante la incisiva insistencia de las Comunidades Autónomas del País Vasco y Cataluña de incluir en sus legislaciones de deporte el carácter único representativo de sus selecciones, el Tribunal Constitucional, ante los recursos de inconstitucionalidad ${ }^{26}$ promovidos por el Presidente del Gobierno en relación con el artículo 19.2 de la Ley del Parlamento de Cataluña 8/1988, de 7 de abril, del Deporte, en la redacción dada por la Ley 9/1999, de 30 de julio, de apoyo a las selecciones catalanas, y contra el artículo 16.6 de la Ley del Parlamento vasco 14/1998, de 11 de junio, del Deporte del País Vasco, establece en los autos de 11 de abril de 2000, para Cataluña, y de 9 de febrero de 1999, para el País Vasco, el mantenimiento de la vigencia de la suspensión de los citados preceptos.

Los argumentos esgrimidos por el auto del $\mathrm{TC}^{27}$ que suspende la vigencia de los artículos mientras que permanezcan sub judice, que podemos considerar como una excepción al actuar del TC en la mayor parte de los recursos de inconstitucionalidad, en los que suele levantarse la suspensión automática de los preceptos impugnados, tienen un doble fundamento:

1) De una parte, se ampara en la reiterada doctrina del Tribunal Constitucional en el sentido de que "la resolución del incidente deberá verificarse llevando a cabo una adecuada ponderación de los perjuicios que pudiera ocasionar al interés general el levantamiento o mantenimiento de la medida suspensiva inicialmente adoptada, así como de la eventual imposibilidad de reparar las consecuencias de una u otra solución. Ponderación que según doctrina igualmente consolidada, debe hacerse mediante el estricto examen de las situaciones de hecho concurrentes en el caso y al margen de todo juicio sobre la viabilidad de la pretensión deducida en el proceso».

26 Recurso de inconstitucionalidad, promovido por el Presidente del Gobierno, núm. 4033/1998, en relación con el artículo 16.6 de la Ley del Parlamento vasco 14/1998, de 11 de junio, del Deporte del País Vasco; y recurso de inconstitucionalidad, promovido por el Presidente del Gobierno, núm. 4596/1999, en relación con el artículo 19.2 de la Ley del Parlamento de Cataluña 8/1988, de 7 de abril, del Deporte, en redacción dada por la Ley 9/1999, de 30 de julio, de apoyo a las selecciones catalanas.

27 Auto de 9 de febrero de 1999, núm. 35/1999 (RTC 1999\35). 
2) Por esta razón entiende que «las legaciones de los Gobiernos Vasco y de la Nación coinciden en centrar sus argumentos en esa vertiente exterior, aunque la norma impugnada habría de desplegar igualmente sus efectos en el ámbito interno (...). Sin prejuzgar, pues, el fondo, ni pretender que el interés general sólo puede verse satisfecho con la garantía de disciplinas normativas unitarias, es preciso coincidir con el abogado del estado en la apreciación de que la vigencia y aplicabilidad de la norma impugnada habría de perjudicar gravemente aquel interés, pues la imagen internacional de España se vería inevitablemente alterada en un foro de tanta y eficaz difusión como es el de las competiciones deportivas, con el riesgo de que, caso de prosperar el recurso de inconstitucionalidad, sería necesario rectificar de nuevo aquella pluralidad y volver al modelo de representación internacional hasta ahora existente. Por su parte el mantenimiento de la suspensión no ha de perjudicar en exceso los intereses a cuyos fines sirve la norma recurrida, pues no hace imposible toda actuación de las federaciones vascas en el ámbito internacional, por lo que no se vacían de contenido las competencias de la Comunidad en las materias de cultura y deportes».

El posterior auto ${ }^{28}$, que mantiene igualmente la suspensión de los preceptos impugnados en el ámbito de la legislación catalana, establece idénticos fundamentos jurídicos; la única diferencia estriba en que en vez de hablar del ámbito de representación internacional de las federaciones habla del ámbito suprautonómico.

Es interesante destacar, a la espera de una resolución definitiva del conflicto, los argumentos esgrimidos por los Gobiernos vasco y catalán en defensa del levantamiento de la suspensión de los artículos referidos.

Las pretensiones jurídicas son las mismas, pero los argumentos algo diferentes:

1) De una parte, el Gobierno vasco afirma que la participación de las federaciones vascas, como tales, en competiciones deportivas internacionales o en foros internacionales deportivos de encuentro y debate no surge directa y exclusivamente del precepto impugnado, pues depende también de las reglas que rijan dichas competiciones internacionales y de la normativa y decisiones de las correspondientes organizaciones y federaciones internacionales.

2) Por otra parte, arguye que la explicación del precepto impugnado conlleva, simplemente, una promoción exterior de competencias propias, las que ostenta sobre el deporte y la cultura, y ello a través de la actividad exterior de sujetos privados en ámbitos y relaciones con otros sujetos igualmente privados, lo cual no implica intromisión alguna en la competencia estatal sobre relaciones internacionales, según se deduce con claridad meridiana de la doctrina del Tribunal Constitucional al respecto ${ }^{29}$.

28 Auto de 11 de abril de 2000, núm. 108/2000 (RTC 2000\108).

29 Sentencia (STC 67/1985, de 24 de mayo) que hace referencia a la naturaleza jurídica de las federaciones deportivas como entidades de Derecho privado pero que, y eso se olvida frecuentemente, ejercen por delegación funciones públicas de forma monopolística. 
3) Como tercer argumento, concibe las manifestaciones deportivas internacionales de las federaciones vascas como expresión de la singularidad cultural autonómica, que se integran en el ámbito de pluralidad cultural que define al Estado (arts. 2 y 149.2 CE), y lleva a cabo un panegírico acerca de las consecuencias y el daño que el mantenimiento de la suspensión provocaría, entendiendo que éste sería «grave y evidente y se cifra en la imposibilidad de realizar una promoción exterior de su propia política deportiva y de su cultura deportiva». Continúa en este sentido manteniendo la necesaria proyección y dimensión internacional del deporte, sin la que parece que el deporte no es nada, y es aquí donde pone mayor énfasis en su argumentación, que pierde, a mi juicio, la necesaria objetividad jurídica y se desenvuelve en un plano político-cultural de exaltación de la cultura propia y de declaración al Estado como enemigo y aniquilador de la cultura deportiva vasca; en efecto, el párrafo no tiene desperdicio: "El que el presente y el futuro deportivo se geste en un ámbito internacional, convierte en papel mojado cualquier poder o competencia sobre regulación del deporte que no tenga potencialidad de proyectarse internacionalmente, y la Comunidad Autónoma tiene competencia exclusiva en materia del deporte. $Y$, visto desde una perspectiva cultural donde también tiene competencia la Comunidad Autónoma, y no sólo competencia, sino el presupuesto esencial de la misma, es decir, una cultura propia uno de cuyos aspectos es el deportivo, ni que decir tiene que el cercenamiento de la posibilidad de comunicación con otras culturas que supondría el mantenimiento de la suspensión supondría la imposibilidad de afirmación, crecimiento, y evolución de esa cultura singular propia, y con ello, el anuncio de su muerte!' ${ }^{30}$.

4) Por último, utiliza el argumento de la naturaleza privada de las federaciones deportivas, que también será utilizado por algunos sectores doctrinales $^{31}$, en el sentido de que establece que «lo que significa el precepto

30 Admiración y negrita de la autora.

31 I. AguirReAzcuÉnAgA, Intervención pública en el deporte, Civitas, Madrid, 1998, págs. 387 y ss. Entiende en este sentido que «ningún problema de competencia puede impedir que la Ley determine que sean las federaciones deportivas españolas las que ostenten la representación de España, aunque no resulte fácil imaginar en clave jurídica cómo una entidad privada pueda encarnar al estado, cuando no es el estado quien participa en las competiciones privadas sino los deportistas en representación de la federación deportiva correspondiente (...)», y continua argumentando en este sentido que "por clara y contundente que sea una ley autonómica en la promoción o reconocimiento de sus selecciones será la federación o asociación deportiva internacional la que decida su incorporación, y en sentido contrario por arduas que sean las trabas internas para la afiliación de las Federaciones deportivas, por ejemplo, al COI, si este organismo acepta de conformidad con sus Estatutos al Comité Olímpico Catalán, los deportistas y federaciones adscritos a tal Comité podrán participar como tales en los Juegos Olímpicos». Y arguye, además, que hay que distinguir entre los conceptos de Estado soberano y país deportivo (del que hablaremos con posterioridad en referencia a la STS en relación con la STSJ de Cataluña 755/1996, de 4 de diciembre), al afirmar que «a este propósito es importante recordar que la nacionalidad deportiva no siempre debe coincidir con la oficial, máxime en el caso de países deportivos que no constituyan un Estado, y recuérdese que en todo caso en las competiciones deportivas internacionales - y por supuesto cuando medie un conflicto- corresponde a la federación supraestatal o al COI determinar el país deportivo de quienes participen en el juego». 
impugnado es que la Comunidad Autónoma otorga a las actividades que sujetos privados realicen en el ámbito internacional privado la función de representar en el ámbito internacional, por un lado, lo culturalmente propio en el aspecto del deporte, y por otro, los logros de la política propia en materia deportivo-cultural, y esto no sólo resulta inofensivo para el interés general del Estado manifestado en sus competencias sobre relaciones internacionales y cultura, sino que es indispensable para mantener reconocible la autonomía política de la Comunidad Autónoma del País Vasco en lo tocante a su cultura y su deporte».

Los argumentos catalanes, sin embargo, diferencian claramente una doble dimensión del deporte en Cataluña, la autonómica y la suprautonómica; los argumentos vascos, como acabamos de advertir, parecen despreciar la visión autonómica del mismo, obsesionados por la anunciada muerte del deporte vasco en caso de suspensión del artículo de referencia.

1) En efecto, por una parte, el Abogado de la Generalidad de Cataluña precisa con carácter general que el «inciso cuestionado otorga a las federaciones deportivas catalanas una presentación circunscrita al deporte catalán y no referida al deporte español en conjunto y que, por ello, es evidente que, al no atribuir a las federaciones catalanas la misma presentación que corresponde a las federaciones deportivas españolas, no interfiere el papel de éstas, de modo que la función de ambas federaciones resulte perfectamente compatible, pues cada una representa un distinto nivel institucional cuya compatibilidad enuncia el artículo 19.1 de la misma Ley».

2) Posteriormente distingue los dos ámbitos de actuación de las federaciones catalanas, el autonómico y el suprautonómico ${ }^{32}$. Como argumento delimitador del ámbito de aplicación del artículo impugnado que atañe a la representación internacional o exterior, hace referencia, al igual que el argumento dado por el Abogado del Gobierno vasco, si bien en referencia específica a las selecciones nacionales y no a las federaciones deportivas, a la circunstancia de que "la actuación de las selecciones deportivas en los foros internacionales no deriva ningún género de obligaciones ni compromisos para los respectivos Estados de procedencia, en el sentido de que tanto la partici-

32 La introducción del término «suprautonómico» en la Ley catalana del Deporte se produjo para evitar la interposición de recurso de inconstitucionalidad, como había ocurrido para el caso vasco, tras el Dictamen del Consejo Consultivo catalán elaborado al respecto, que asimismo instó la modificación de la obligación de los deportistas catalanes a asistir a las convocatorias de las selecciones, si bien tanto el diputado de ERC Ernest Benach como el de IC-V Ignasi Riera admitieron que el término "suprautonómico» es un eufemismo, ya que el objetivo es «la representación internacional y oficial del deporte catalán con selecciones propias»; por otra parte, el diputado del PP Daniel Sierra criticó la Ley en el sentido de que «abre la puerta a un futuro enfrentamiento deportivo entre Cataluña y España», aunque ya dejó claro que la Ley catalana se trataba de un texto de imposible cumplimiento ya que «sólo responde a un intento de calentar la próxima campaña electoral». Vid. La Estrella Digital, edición del 29 de julio de 1999: "Las selecciones catalanas podrán competir en eventos internacionales». 
pación como los resultados no comprometen de ningún modo la responsabilidad estatal», y añade que esta circunstancia es "lógica consecuencia del carácter absolutamente privado, tanto de los entes "internacionales" que organizan competiciones, como de las federaciones o entidades deportivas que intervienen en ellas».

3) Para consolidar esta argumentación hace referencia al ejemplo británico, al precisar que de la misma manera que es notorio que la selección de Gales no representa a Gran Bretaña, también habrá de serlo que la selección catalana representará al deporte catalán y no al de todo el Estado español, aduciendo además que las únicas y eventuales dificultades de acomodación para la imagen exterior de España, en torno a la representatividad de las federaciones catalanas y españolas, se suscitan sólo en el supuesto concreto de una hipotética competición internacional en la que se aceptara la participación simultánea de la selección española y de la selección catalana, de manera que la representación del Estado en su conjunto pudiera aparecer enfrentada a la de sus partes. La solución posible a este entuerto venía regulada en la anterior Ley 13/1980, General de la Educación Física y del Deporte, que admitía que las federaciones autonómicas o preautonómicas pudieran participar en las competiciones internacionales siempre que no lo hiciera la Federación Española de la misma modalidad deportiva.

Los argumentos dados por el Abogado de la Generalidad de Cataluña son, a mi juicio, más sólidos que los esgrimidos en el caso vasco; sin embargo, adolecen, a mi entender, de dos carencias o dos omisiones que dificultan la defensa de su posición:

1) Por una parte, y al igual que en el caso anterior, el argumento del carácter absolutamente privado de las federaciones o entidades deportivas que intervienen en las competiciones internacionales no es del todo cierto. La sentencia 67/1985 del Tribunal Constitucional y la Ley del Deporte 10/1990 establecen con carácter general la naturaleza jurídico-privada de las federaciones deportivas, si bien éstas en algunos casos, que, como ya hemos advertido, suponen la mayoría de sus actuaciones y competencias, actúan como agentes colaboradores de la Administración, como Administración Pública en suma, la publificación, de facto, de las federaciones es un hecho cierto, por lo que debe realizarse una distinción clara de las funciones públicas y privadas que ejercen para dirimir si la representación internacional de las federaciones supone una función pública o no.

2) Por otra parte, la afirmación de que de la actuación de las selecciones deportivas en los foros internacionales no se deriva ningún género de compromisos para los respectivos Estados de procedencia es también matizable, pues debemos anudar esta afirmación al hecho de que la financiación de las selecciones y de las federaciones, y los planes de promoción y desarrollo de los deportistas de élite, aparecen vinculados la mayor parte de las veces a la obtención de determinados resultados en competiciones de 
carácter internacional $^{33}$, por lo que sí existe responsabilidad del Estado en cuanto a las actuaciones de sus selecciones y deportistas individuales, que dependen, muchas veces, de la obtención de resultados concretos para la inclusión en la lista de deportistas de alto nivel y la financiación de su participación en Juegos Olímpicos y competiciones internacionales.

En este mismo sentido habrá también que tener en cuenta que la obtención de resultados y la participación en competiciones de alto nivel generan una serie de privilegios o derechos a los deportistas que son garantizados por el Estado (exención del servicio militar, derecho al acceso directo a determinadas carreras universitarias vinculadas con el mundo del deporte, derecho a formar parte de la Asamblea General del CSD, entre otros).

Pero es que, además, y este asunto no lo plantean ni vascos ni catalanes, existe un problema de fondo, y es que el asunto que se plantea, y que late tras esta reclamación, es el reconocimiento de dos Comunidades Autónomas para ejercer su propia representación internacional al margen o con independencia de la representación internacional española, y que conduce a otra cuestión que, por supuesto, no plantean los recursos analizados, y es que la consecuencia de una posible legitimación tanto de las selecciones como de las federaciones catalanas y vascas para ejercer su propia representación internacional plantea una cuestión derivada inmediata de índole competencial y organizativa, y no es otra que la posibilidad de reconocimiento de otras 15 selecciones y federaciones «internacionales» autonómi$\operatorname{cas}^{34}$, porque aquí o jugamos todos, y nunca mejor dicho, o se rompe la baraja.

La cuestión, presentada de forma tan natural para el caso del Reino Unido, creo que no lo es tanto en nuestro entorno, en el que no ha existido una tradición, y aquí sí apelamos nosotros a que las raíces culturales e his-

33 Curiosamente, AguiRreazcuÉnAga (op. cit., pág. 397) apunta este argumento de forma peregrina, como si de una cuestión baladí se tratara, a la hora de calificar el ámbito de actividad de las federaciones, puesto que su argumento, al igual que el de las representaciones catalana y vasca en los recursos, gira en torno a la naturaleza privada de las federaciones; sin embargo, como advertíamos, no duda en manifestar que «la Ley publifica la ordenación de la representación del deporte vasco en las competiciones estatales e internacionales, ya que considera como función pública de carácter administrativo el ejercicio de la representación del deporte vasco por parte de las federaciones enraizadas en la Comunidad autónoma (...). Por lo tanto la publificación tendrá nulos o escasos efectos prácticos en el ámbito de las competiciones internacionales, a no ser que a ello se pretenda anudar la pléyade de subvenciones previstas por el Gobierno Vasco en relación con el deporte internacional».

34 En este sentido observamos cómo la Ley 6/1998, de 14 de diciembre, del Deporte de Andalucía, reconoce la existencia de las selecciones andaluzas en su artículo 41, que las define como "las relaciones de deportistas designados para participar en una competición o conjunto de competiciones deportivas determinadas en representación de la Comunidad Autónoma de Andalucía. (...) Los deportistas federados vendrán obligados a asistir a las convocatorias de las selecciones andaluzas en los términos que reglamentariamente se determine». Si bien, a pesar del reconocimiento de las mismas, no se establece en el precepto el ámbito de representación en el que éstas se desenvolverán, por lo que el problema de constitucionalidad no parece que se pueda plantear en los mismos términos que para las selecciones catalanas y vascas. 
tóricas del deporte en el Reino Unido, verdadera cuna del deporte moderno ${ }^{35}$, han conducido a esta forma de representación, no como bandera política y como efecto de una reivindicación ajena, en el fondo, a la materia deportiva, sino como una consecuencia lógica del carácter insular de Gran Bretaña, y de la fuerte tradición competitiva existente entre las diferentes regiones británicas.

La participación británica mediante selecciones independientes (Escocia, Gales, Inglaterra e Irlanda del Norte) no es, pues, un logro político, sino fruto natural y no forzado de la existencia de un fuerte movimiento deportivo, con poder autoorganizativo, previa además al proceso de descentralización del Reino Unido y la creación de los Parlamentos regionales británicos, y previa incluso a la existencia de un gran número de federaciones internacionales.

Los problemas derivados de esta espinosa y delicada confrontación, con mucho mar de fondo, han provocado reacciones de diversa índole, políticojurídica y económica.

1) De una parte, la reforma de la Ley del Deporte 10/1990 se encuentra paralizada por la oposición inicial de vascos y catalanes al primer borrador que se presentó sobre la misma, ya que PNV y CiU exigían en la inclusión de su articulado alguna mención a las pretensiones de las selecciones vascas y catalanas $^{36}$

2) Por otra parte, no parece que las federaciones deportivas internacionales vean con buenos ojos la posibilidad de creación de 17 selecciones autonómicas españolas, y sus correspondientes federaciones internacionales, lo que ya perjudicó negativamente a la candidatura, entre otras, a la organización del Campeonato Europeo de Fútbol de $2004^{37}$.

35 Vid., al respecto, R. REAL FERrer (op. cit., pág. 257), que no duda en afirmar que «el deporte tal como lo conocemos hoy surgió en Gran bretaña en el seno de unas condiciones socioeconómicas especiales, formateándose según las reglas festivas y de ocio de determinadas clases sociales». En el mismo sentido, D. MANDELl Richard, Historia cultural del deporte, Bellaterra, Barcelona, 1986; Dumonds, Pollet y BERFAst, Naissance du sport moderne, La manufacture, Lion, 1987.

36 El País Digital, 16 de enero de 1998: «La nueva ley del Deporte estuvo bloqueada por vascos y catalanes. El borrador de la ley del Deporte ha vivido una situación de bloqueo durante los dos últimos meses a causa de la pretensión de los socios nacionalistas del gobierno, PNV y $\mathrm{CiU}$, de incluir en su articulado alguna mención a las pretensiones de las selecciones vascas y catalanas por obtener un reconocimiento internacional. Finalmente la situación ha quedado en una especie de pacto de no hostilidad, según el cual, al menos en esta legislatura, vascos y catalanes no serán combativos en ese asunto, y por su parte el CSD no pondrá objeciones a que organicen partidos y torneos. Tras este pacto, la ley del Deporte pasará el trámite de subsecretarios para ir al Parlamento». Sin embargo, tras este aparente e inicial "pacto de no agresión», se aprobó la nueva Ley catalana del Deporte y se interpusieron los recursos de inconstitucionalidad anteriormente comentados. La reforma de la Ley del Deporte parece, pues, estar a la espera de los pronunciamientos que el Tribunal Constitucional haga a este respecto.

37 La Estrella Digital, en su edición de 26 de diciembre de 1998, se hacía eco de este problema y resume la situación concreta en el caso del fútbol: «La formación de selecciones de fútbol de las diversas comunidades autónomas puede repercutir negativamente en la candidatura de España para organizar el Campeonato de Europa del 2004 y, por consiguiente, bene- 
La ansiada y anhelada representación internacional del deporte catalán ha sufrido un duro embate como consecuencia de la sentencia del Tribunal Superior de Justicia de Cataluña de 4 de diciembre de $1996^{38}$ y la sentencia del Tribunal Supremo que resuelve el recurso de casación interpuesto por la Generalidad de Cataluña contra la citada sentencia que confirma el fallo de la misma. La sentencia resuelve el conflicto suscitado como consecuencia de la pretensión de las federaciones deportivas catalanas de poderse constituir en país olímpico y, de esta forma, poder presentar en los Juegos Olímpicos sus propias selecciones al margen de las selecciones españolas. Los principales fundamentos de Derecho que esgrime el Tribunal Superior de Justicia de Cataluña, que confirmará posteriormente el Tribunal Supremo, se centran en el examen de la legalidad de los preceptos impugnados del Decreto 70/1994, de 22 de marzo, por el que se regulan las Federaciones Deportivas Catalanas, que hace necesario partir de la delimitación de las respectivas competencias del Estado y de la Comunidad Autónoma que se deduce de la normativa vigente.

En este sentido, el Tribunal Superior de Justicia de Cataluña parte de la delimitación de competencias existente en materia de deporte y, así, establece que el artículo 9.29 del Estatuto de Autonomía señala que la Generalitat de Cataluña tiene competencia exclusiva en materia de deportes y ocio. Sin embargo, no cabe olvidar que el ejercicio de tales competencias se entiende referido al territorio de la propia Comunidad Autónoma, conforme a lo dispuesto en el artículo 25.1 del propio Estatuto, de lo que cabe deducir que «aunque el territorio no opera como criterio de distribución de competencias, sí resulta relevante como límite externo del ejercicio de las mismas».

Por esta razón, continúa argumentando, la cuestión litigiosa que subyace consiste en la determinación de la forma en que debe articularse la participación deportiva en determinadas competiciones internacionales y, en concreto, en el Movimiento Olímpico. En consecuencia, no se debaten mera-

ficiar a la de Portugal, según el presidente de la Federación Portuguesa (FPF), Gilberto Madail. En declaraciones que publicó ayer el diario deportivo lisboeta "Jogo", Madail, sobre los recientes partidos de equipos de algunas Autonomías, comentó que esa situación no es muy buena para la Real Federación Española de Fútbol (RFEF). "Creemos que quien representa al fútbol español es su selección, pero estas situaciones no son buenas para el fútbol de todo un país". Aseguró que la selección portuguesa ya recibió invitaciones para enfrentarse a la de alguna comunidad autónoma, pero advirtió que "sólo en situaciones muy especiales se podría aceptar y siempre de acuerdo con la respectiva federación". Recordó que en el marco de la UEFA están previstos partidos entre selecciones de las diversas regiones de Europa, pero "siempre entre equipos con el mismo estatuto", en referencia a los recientes partidos entre Cataluña y Nigeria, el País Vasco y Uruguay o Canarias y Letonia. Tras recordar la política española de autonomías, el presidente de la FPF advirtió que España podría tener problemas por esta causa para lograr la organización de la Eurocopa del 2004. Dijo que "esa es una pregunta pertinente sobre la cual la UEFA tendrá que pensar a la hora de elegir" la sede de ese europeo de naciones, al cual también es candidata Portugal. Aventuró que por causa de las comunidades autónomas, España presentó 15 estadios para disputar la Eurocopa del 2004 en lugar de los 10 necesarios, para después eliminar cinco de ellos. Añadió que la RFEF, que tendrá muchos problemas para eliminar esos cinco estadios, no puede permitir "situaciones independentistas y autonómicas" como las sucedidas esta semana».

38 Sentencia del Tribunal Superior de Justicia de Cataluña 755/1996, de 4 de diciembre. 
mente cuestiones relativas a la proyección exterior de las competencias que corresponden a la Generalidad de Cataluña en el ámbito territorial que le es propio, sino que se plantea la forma que debe adoptar la representación en el ámbito internacional del deporte español en su conjunto ${ }^{39}$.

En consecuencia, la resolución del presente litigio no puede prescindir del contenido de la Ley 10/1990, de 15 de octubre, que regula aspectos relevantes de la participación española en el Movimiento Olímpico y que, por ello, constituye parámetro de la legalidad del Decreto impugnado.

Por otra parte, el TSJ de Cataluña precisa que «el artículo 88.2.i) del Decreto impugnado atribuye a la Unión de Federaciones Deportivas Catalanas la promoción de la participación catalana en el movimiento olímpico y el reconocimiento de Cataluña como país deportivo. Esta concreta atribución de funciones es discutida por la Administración del Estado por entender, en primer lugar, que la misma excede del mandato legal contenido en la Ley catalana 8/1988, de 7 de abril.

Por esta razón se hace preciso a la vista de cuanto antes se ha expuesto distinguir entre las funciones de fomento exterior del deporte catalán que el apartado g) del propio artículo 88.2 atribuye asimismo a la Unión de Federaciones Deportivas Catalanas, las cuales se corresponden con el principio recogido en el artículo 3.2.r) de la Ley 8/1988 como uno de los que deben inspirar la política deportiva de la Generalidad (promover y difundir el deporte catalán en los ámbitos estatal e internacional), y, por otra parte, las que recoge el apartado i), cuya finalidad es la de articular la participación del conjunto del deporte español en el movimiento olímpico sobre bases distintas de las actuales.

Desde esta perspectiva, el Reglamento impugnado no encuentra amparo en la Ley catalana 8/1988, que no se refiere a esta cuestión en absoluto, al tiempo que contradice lo dispuesto en el artículo 48.5 de la Ley estatal 10/1990, de 15 de octubre, que reserva al Comité Olímpico Español la representación exclusiva de España ante el Comité Olimpico Internacional».

Con base a estos dos fundamentos jurídicos que acabamos de resumir se declara la nulidad de los artículos 3.3 y 88.2.i) del Decreto 70/1994, de 22 de marzo, por el que se regulan las Federaciones Deportivas Catalanas.

En definitiva, lo que plantean estas dos sentencias, la del TSJ de Cataluña y la del Tribunal Supremo que la confirma, es el hecho de que en el momento en que las federaciones deportivas o el movimiento deportivo de una determinada Comunidad Autónoma pretenden desarrollar sus competencias en un ámbito territorial superior al suyo propio, y sobre todo al ámbito internacional, la cuestión no es de exclusiva competencia de cada Comunidad Autónoma, pues, como advertíamos, incide implícita pero directamen-

39 Esta circunstancia justifica la intervención normativa del legislador estatal, como se deduce de la sentencia del Tribunal Constitucional 1/1986, de 10 de enero, que declaró que «la autonomía [está] constitucionalmente garantizada a las Comunidades Autónomas, al servicio de la gestión de sus intereses propios (art. 137 de la Constitución), limitados ratione loci (art. 25.1 del Estatuto de Autonomía de Cataluña), y no siendo desde ella posible, ciertamente, la afectación (...) de intereses que son propios del deporte federado español en su conjunto". 
te en la propia configuración que de la representación exterior de todos los entes territoriales autonómicos y sus «agentes colaboradores», es decir, las federaciones deportivas, se haga.

\subsection{De la "vía de hecho» catalana a la "guerra de las camisetas» en el Congreso de los Diputados}

Hasta que no queden resueltos los recursos contra las Leyes vasca y catalana del Deporte, la presión soberanista-deportiva se ha volcado no tanto en disposiciones legislativas, pues la reforma del Estatuto catalán es, a mi juicio, muy discreta en este sentido ya que no recoge el deporte en el elenco de derechos, deberes y principios rectores, sino que posterga su aparición hasta el capítulo II de materias de las competencias, haciendo una ambigua alusión a la representación internacional como principio participativo y no representativo al establecer que «la Generalitat participa en entidades y organismos de ámbito estatal, europeo e internacional que tengan por objeto el desarrollo del deporte».

Entretanto se hace ruido mediático con inscripciones más o menos fraudulentas de federaciones internacionales catalanas y con celebraciones, también más o menos polémicas, de competiciones y partidos entre selecciones autonómicas y selecciones, oficiales y no oficiales, de otros Estados.

Las federaciones internacionales catalanas.

- El caso de la Federación Catalana de Patinaje. Breve resumen de las actuaciones de la Federación Catalana de Patinaje para lograr el reconocimiento de la Federación Internacional de Patinaje (FIRS) y de las consecuencias políticas de la decisión.

La Federación Catalana de Patinaje obtuvo el reconocimiento como miembro con carácter provisional del máximo organismo internacional del patinaje, en la reunión del Comité Central de la FIRS celebrada en marzo de 2004 en Miami, lo que conllevó la posibilidad de que se pudieran llegar a medir en competiciones internacionales las selecciones española y catalana.

Aunque no figuraba aquel asunto en el orden del día, el Presidente de la Federación Catalana, Ramón Basiana, se presentó en Miami en la reunión del Comité Central de la FIRS, que presidía el también catalán Isidro Oliveras, para defender la adhesión de Cataluña como nueva Federación, algo que consiguió con el voto a favor de los doce miembros de este organismo.

El acuerdo debía ser refrendado por mayoría en la próxima Asamblea de la FIRS, que se celebraría el 26 de noviembre en Estados Unidos. El Consejo Superior de Deportes manifestó en un primer momento su intención de denunciar la situación creada tanto ante el Comité Olímpico Internacional (COI) como ante la Asociación Internacional de Federaciones Deportivas (GAISF), entes a los que está afiliada la FIRS, así como de incoar un expediente disciplinario frente a la Federación Catalana. 
Ante el boicot de otras federaciones nacionales, entre ellas Italia y Francia, la Federación Catalana decidió no presentarse al Campeonato Mundial de Hockey sobre Patín en Línea, que se celebró en julio en Canadá.

Sin embargo, el 26 de noviembre de 2004, la FIRS, de forma excepcional, decidió denegar la afiliación definitiva de la Federación Catalana de Hockey sobre Patines y, por tanto, mantenerse fiel a los nuevos criterios que tanto las federaciones internacionales, con algunas excepciones, como hemos analizado, como el Comité Olímpico Internacional están practicando en cuanto a la identificación nacional-estatal de las nuevas federaciones o Comités Olímpicos Nacionales que vayan surgiendo ${ }^{40}$.

Las consecuencias políticas, que no deportivas ni jurídicas, de esta coherente decisión, a la vista de todo lo expuesto hasta el momento, no se han hecho esperar y, así, en prensa se recogieron titulares como «El hockey patines enciende la polémica». La decisión de la Federación Internacional de Deportes de Patinaje de no admitir a la Federación Catalana, impidiendo así que su Selección de Hockey sobre Patines pueda enfrentarse a la española en el próximo Mundial A de la especialidad, ha encendido la polémica en el deporte español.

— La federación «internacional» catalana de fútbol sala.

El caso del fútbol sala es algo diferente al anteriormente descrito, en el que el reconocimiento preliminar vino de parte de la Federación Internacional de Patinaje; sin embargo, en el caso del fútbol sala se trata de una Asociación Mundial de Futbol Sala en la que, en principio, pudieran participar asociaciones que no representen de forma monopolística el deporte, si bien, a mi juicio, es perfectamente legítimo que pudiera acudir una representación catalana, como una representación del fútbol de Valdemorillo, siempre y cuando, como hemos explicado anteriormente, de este tipo de competiciones no se deriven efectos que puedan trascender a la esfera jurídico-pública. Pero es claro, como expresivamente señalan los artículos de

40 Sin embargo, la cuestión de este tipo de «vías de hecho» no está resuelta del todo y, así, el fútbol sala catalán ha obtenido el reconocimiento de la UEFS.

La Federación Catalana de Fútbol Sala (FCFS) ha obtenido el reconocimiento de la Unión Europea de Futsal (UEFS), un organismo independiente de la FIFA y la UEFA que organiza de forma paralela competiciones de selecciones y clubes y del que no forma parte España. Este hecho ha generado tensiones entre la Unión de Federaciones Deportivas Catalanas (UFEC), la Generalitat y la Federación Catalana de Fútbol, órgano que da cobijo al fútbol sala en Cataluña, que rechaza este acuerdo.

La nueva Federación de Futsal está inscrita en el registro de entidades desde hace seis meses, pero la polémica se ha trasladado a la opinión pública, después de que el equipo femenino de esta nueva Federación representase a Cataluña en un europeo celebrado en Rusia en el que compitieron seis equipos. El pasado 27 de noviembre, la Secretaría General de Deportes de la Generalitat inscribió de forma definitiva en el registro de entidades deportivas catalanas a esta nueva Federación de Futsal, después de las presiones recibidas tras una última sentencia favorable en 1999 por parte del Tribunal Superior de Cataluña. En opinión del responsable deportivo de la Generalitat, «hay que cumplir la ley» y, por ello, la FCF debe «acatar» la sentencia que permitió a la FCFS inscribirse como entidad. 
prensa $^{41}$, que el objetivo político, lograr (más que una representación internacional oficial) una resonancia internacional, se ha logrado, a pesar de la dudosa reputación de los organizadores de la competición y de la ilegalidad de la existencia misma de una Federación Española de Futbol Sala, como reiterada jurisprudencia ha manifestado.

41 Más que de fútbol sala, habría que hablar de fútbol trampa o de fútbol pirata, para referirse a la organización deportiva por la que Cataluña, con el apoyo de la Generalitat y el desamparo de las instituciones del Estado, ha conseguido alcanzar representatividad internacional en las canchas. Después de la Copa Mundial de Yakutia, un esperpento de competición en un rincón de Rusia, Cataluña disputa a partir de este fin de semana un Mundial paralelo en Mendoza (Argentina), junto a selecciones de 15 países, todos ellos soberanos. En su grupo están Paraguay, Italia y Ecuador, su primer rival, el próximo sábado.

No se trata, sin embargo, de la Cataluña más potente en la pista, cuyos jugadores militan en la Liga Nacional de Fútbol Sala (LNFS) y en la selección española, campeona del mundo. Pero eso es lo de menos, porque el objetivo no es deportivo, es político. Esta selección de la Federación Catalana de Fútbol Sala, que escapa al control de la Federación Catalana de Fútbol, la oficial, recibe una asignación de la Generalitat. En un año ha pasado de 45.000 a 116.000 euros, 81.000 de los cuales están específicamente destinados a actividades internacionales. Gracias a ese apoyo, se ha integrado en unas asociaciones internacionales, la Unión Internacional de Futsal (UEFS) y la Asociación Mundial de Futsal (AMF), dirigidas por personajes de dudosa reputación en el ámbito deportivo internacional.

Además de Cataluña, en la UEFS se encuentran reconocidas como miembros las «Provincias Vascas». El organismo europeo está presidido por Valery Akhumyan, el empresario ruso que organizó el torneo de Yakutia, donde Cataluña se enfrentó a una fraudulenta selección española. En 2003, los antiguos dirigentes del fútbol sala mundial enviaron una carta al Ministerio de Deportes de Rusia en la que denunciaban el «uso ilegítimo» del nombre de la antigua federación mundial (FIFUSA) y el presunto «afán de lucro» de Akhumyan.

Al frente de la AMF, por su parte, aparece el paraguayo Rolando Alarcón, que sufrió un expediente de expulsión por parte de su propio Comité Olímpico Nacional. El Secretario General es el argentino Pedro Ramón Bonettini, vinculado en su país a la Confederación Argentina de Deportes, organismo creado durante el peronismo y que se encarga de las asignaciones estatales a las federaciones. Bonettini fue denunciado en diversos medios de comunicación por ser un ñoqui, que es como se denomina en Argentina a aquellos que cobran un sueldo municipal, en este caso en la ciudad de Oberá, sin acudir a trabajar. El apodo viene de la tradición de comer ñoquis los días 29 de cada mes con dinero debajo del plato. De ahí que los ñoquis sean quienes pasan a final de mes sólo a cobrar.

Akhumyan tiene como Vicepresidente al Presidente de la Federación Catalana de Fútbol Sala, Josep Maria Zamora Monje, y Rolando Alarcón al de la Gallega, Luis Pena. El jefe de la Comisión de Árbitros Europea es Arsenio Palenzuela, que abandonó con polémica la Madrileña.

El ascenso de estos personajes a cargos internacionales se produce debido a la falta de control por parte del Consejo Superior de Deportes (CSD) y de la Federación de Ángel Villar, a raíz de la supresión de la Federación Española de Fútbol Sala, que presidía Antonio Alberca. La situación viene de lejos, pero es necesario explicar la secuencia para conocer la dimensión del problema y sus riesgos. En 1982, Alberca fundó la Federación Española de Fútbol Sala. Llegó a tener 300.000 licencias, pero el CSD, regido entonces por Rafael Cortés Elvira, le obligó a integrarse en la Federación Española de Fútbol. Ello obedecía a una tendencia internacional, porque FIFA quería apoderarse del control del fútbol sala. Alberca se negó y, en 1993, el CSD acabó por ganar el pulso después de un largo proceso judicial que pasó por el Constitucional y el Supremo.

Alberca había escalado por entonces a la presidencia de la Federación Internacional (FIFUSA), de la que dimitió en 2003, no sin antes denunciar a sus gobiernos las actitudes de Akhumyan y Alarcón, que aprovecharon la antigua infraestructura para crear la nueva AMF.

Villar acogió el fútbol sala de élite, la Liga Nacional y la selección campeona del mundo, pero quedó un magma de clubes adscritos a las federaciones territoriales, que seguían acti- 


\section{La guerra de las camisetas.}

El debate sobre la propuesta de Ley presentada por CiU y ERC para la reforma de la Ley del Deporte será recordado como el de «la guerra de las camisetas».

Independientemente de la mayor o menor efectividad y luminosidad del espectáculo ofrecido por sus señorías ${ }^{42}$, el resultado ha sido la suspensión

vas y susceptibles de ser utilizadas por los gobiernos autónomos. Eso es lo que ha ocurrido en Cataluña, donde el deporte se encuentra en manos de ERC tras el reparto de competencias realizado por el tripartito que encabeza el socialista José Montilla.

El deporte depende directamente de la vicepresidencia de Josep Lluís Carod-Rovira, que tiene entre sus hombres de confianza a Rafel Niubó, anterior Secretario de Deportes de la Generalitat. Niubó dejó el cargo a Anna Pruna, una persona de su estrecha confianza, con la que ya había trabajado en UBAE, una asociación de instalaciones deportivas.

La Generalitat subvenciona con más de un millón de euros a la Plataforma pro Seleccions, que apoya de forma logística a esta selección. Según Xavier Vinyals, miembro de esta Plataforma, «lo hacemos como a todas las demás». A la Federación Catalana de Fútbol, la oficial, que dispone de un Comité técnico dedicado al fútbol sala, le incomoda este intrusismo, pero no quiere tomar una posición políticamente incorrecta frente a la Generalitat. Tiene pleitos judiciales por el reconocimiento oficial del fútbol sala y con su Presidente, Zamora Monje. Sus actividades adolecen del apoyo mediático que tiene la selección catalana que competirá en Argentina, sobre todo en los medios afines a la Generalitat.

El Consejo Superior de Deportes (CSD) ha enviado una notificación a las autoridades deportivas de Argentina, donde mañana arranca el Mundial de Fútbol Sala de la AMF, en la que incide en que la representación del Estado corresponde únicamente a la selección española. El Gobierno español no reconoce, pues, como tal el torneo de Mendoza y se remite al oficial, que se disputará en Brasil en 2008.

Consultado por este periódico, un portavoz del organismo presidido por Jaime Lissavetzky, que ayer se encontraba en el sepelio del futbolista del Sevilla Antonio Puerta, reconocía que existe un "vacío de competencias» por el hecho de haber desaparecido la Federación Española de Fútbol Sala. La situación se inició en la etapa de Rafael Cortés Elvira como Secretario de Estado para el Deporte y desde entonces no ha variado, ni con el PP ni con el PSOE.

Desde la Federación de Villar, por su parte, sostienen: «Nosotros nos ocupamos del fútbol sala oficial, controlamos la competición de élite y la selección, que es campeona del mundo». "Lo demás - prosigue la fuente- para nosotros es como si no existiera, porque no está reconocido por la FIFA, que es por la que nosotros nos regimos».

42 «Solo faltó el balón. La discusión de sendas iniciativas de CiU y ERC sobre las selecciones autonómicas demostró ayer en el Congreso de los Diputados hasta qué punto puede el deporte convertirse en política... y la política en deporte. Durante el debate afloraron una vez más las viejas tensiones territoriales, que el PP lleva exacerbando desde hace unos días con la polémica de las banderas, y salieron a relucir como en cualquier estadio que se respete camisetas de todos los colores, en este caso españolas, catalanas, vascas y gallegas. Al final, la selección española - véase PSOE y PP, con el refuerzo de Coalición Canaria- derrotó por goleada al combinado integrado por las demás fuerzas. La proposición de ley de ERC cayó por 33 votos contra 269. La de CiU, por 32 contra 270 . Una vez más, la reforma de la ley del deporte tendrá que esperar.

Abrió el juego el republicano Joan Puig, exponiendo su iniciativa: que los deportistas puedan negarse a jugar en la selección española invocando cualquier motivo, incluso el ideológico. Puig confesó hallarse entre los "miles" de catalanes, vascos y gallegos que "no disfrutan de los triunfos de la selección española”. Más que atacar al PP — cuya postura se daba por descontada-, el republicano dirigió sus puntapiés al Gobierno y al PSOE. Los acusó de "juego sucio" y "malas artes" por frenar una reivindicación que los socialistas apoyaron en junio del 2004 cuando se debatió una moción parecida.

Miedo a perder su juicio, la actitud del Ejecutivo tiene una explicación: el "miedo a perder". "Tiene miedo a que suceda lo que pasó en fútbol sala cuando Catalunya ganó a España", dijo. Puig invitó a los diputados a imaginar un mundo feliz en el que los españoles pu- 
de la posibilidad de la reforma de la Ley del Deporte, quedando a la espera de nuevo de lo que el Tribunal Constitucional resuelva sobre los recursos interpuestos contra las Leyes del Deporte de Cataluña y el País Vasco. Mucho ruido y pocas nueces.

dieran ver un enfrentamiento de "Gasol y Rudy Fernández contra Garbajosa”. “¿Se lo imaginan?”, dijo. Josep Maldonado, de CiU, que defendió en nombre de su grupo el derecho de las federaciones autonómicas a integrarse en las asociaciones internacionales, también salió en tromba contra los socialistas. "No nos dejan jugar ni cuando vamos de pícnic", se quejó en alusión al prohibido Catalunya-EE.UU. de fútbol. Su intervención fue cada vez a más hasta alcanzar el clímax. "Señorías, hay muchos niños y niñas catalanes que tienen colgada en alguna pared de su habitación una camiseta de la selección nacional como esta, y muchas noches sueñan con que un día no muy lejano se la podrán poner y competir", dijo, y exhibió una camiseta de la selección catalana.

El socialista Agustín Jiménez defendió el "juego limpio" del Gobierno. Más contundente, Francisco Antonio González, del PP, retó a los portavoces catalanes a pedir a Joan Laporta que renuncie a que su equipo participe en la Liga española y tenga "Liga propia catalana". González dijo sentir "orgullo" por una camiseta "que representa a todos", y la exhibió: la española, por supuesto. Se escucharon varios noes. Un diputado vasco y una gallega respondieron aireando camisetas de sus respectivas comunidades. En respuesta a varias alusiones de Maldonado a la "lucha" de los catalanes, el portavoz conservador alegó que Catalunya no logró el restablecimiento de la Generalitat "como consecuencia de la lucha", sino por el "consenso y el diálogo". Al final, victoria españolista y pose de los perdedores en las escalinatas del Congreso con sus camisetas nacionales, o autonómicas, según los gustos». 



\title{
LA REFORMA DE LAS LEYES MILITARES EN EL CONTEXTO DE LOS CAMBIOS EN LA SEGURIDAD Y LA DEFENSA
}

\author{
Dr. JuAN-Cruz Alli Turrillas* \\ Profesor Titular de Derecho Administrativo \\ Universidad Nacional de Educación a Distancia
}

\begin{abstract}
I. INTRODUCCIÓN GENERAL: 1. Justificación de este estudio: las recientes reformas militares en su contexto. 2. La defensa y organización militar y el Derecho administrativo.-II. EL PANORAMA PREJURÍDICO DE LA SEGURIDAD Y LA DEFENSA: 1. Viejas y nuevas guerra: 1.1. Nuevos conflictos, viejos problemas. 1.2. Visiones teóricas sobre el nuevo entorno de seguridad. 2. El cambio en los paradigmas o los nuevos enfoques de la seguridad: 2.1. Revolución o evolución en los asuntos militares. 2.2. El perpetuum mobile de la "transformación». 2.3. Las coordenadas perpetuas de la guerra. 3. La integración: combinación, conjunción, interoperabilidad y modularidad.-III. LOS NUEVOS RETOS O AMENAZAS A LA SEGURIDAD «NACIONAL»: ASPECTOS JURíDICOS: 1. Defensa y seguridad nacional: la Ley Orgánica de la Defensa Nacional de 2006. 1.1. El panorama de las misiones exteriores de las FAS y su marco constitucional. 1.2. La «Revisión Estratégica de la Defensa». 1.3. Ley Orgánica 5/2005, de la Defensa Nacional: A) Una reforma legislativa necesaria, pero desaprovechada. B) En prticular, el fin, misiones y funciones de las FAS. 2. La modernización necesaria: 2.1. ¿Defensa o seguridad nacional?: A) La ausencia de una visión clara en la LODN. B) Falta de integración de estructuras en ese concepto amplio de seguridad. 2.2. Reformas estrictamente militares: A) Reforma de estructuras. B) Y la mágica aparición de la Unidad Militar de Emergencias. 2.3. Reforma de medios y doctrinas: algunas propuestas.-IV. LA TRANSFORMACIÓN DEL PERSONAL DE LAS FUERZAS ARMADAS: 1. El personal de las Fuerzas Armadas: 1.1. ¿Ejército voluntario o ejército profesional?: A) Panorama general. B) Precisión conceptual. 1.2. El ejército voluntario: A) Creación y crisis del ejército voluntario. B) La Ley 8/2006, de Tropa y Marinería (LTM) o del «ejército voluntario». C) Mandos de complemento. 1.3. La reserva. 2. El régimen del militar «de carrera»: Ley de la Carrera Militar (LCM): 2.1. Marco general. 2.2. Algunos aspectos destacados de la LCM: A) Estructura básica de la LCM. B) Las redundantes reglas del comportamiento militar, derechos y libertades, y las Reales Ordenanzas para las Fuerzas Armadas. C) La salvadora presencia de la mujer en las FAS y su regulación. D) La innecesaria reforma de la enseñanza militar. E) Las variables reformas en cuerpos, escalas y especialidades. F) El delicado régimen de ascensos.-V. ConcLusión.
\end{abstract}

\section{RESUMEN}

Este estudio de la reforma de las principales leyes militares en España parte del análisis de la realidad geoestratégica y los retos a la seguridad global. Todo ello se pone, también, en relación con las concepciones teóricas sobre la seguridad y sus amenazas y riesgos elaboradas en los últimos años. Se recorren, así, conceptos como la «Revolución en los Asuntos Militares», la «Transformación» y otros, realizando un análisis crítico. Luego se examina la Ley Orgánica 5/2005, de 17 de noviembre, de Defensa y Organización Militar, que sustituye a la de 1980-84; a continuación la novedosa Ley 8/2006, de 24 de abril, de Tropa y Marinería, y finalmente se estudia la Ley de la Carrera Militar, aún pendiente de aprobación por las Cortes Generales.

Palabras clave: España; defensa y seguridad nacional; ejércitos; ejército profesional; militares profesionales.

\footnotetext{
* Máster en Seguridad y Defensa (JUGM).
} 


\section{ABSTRACT}

This is an study of the reformation of the basic military laws system wich has taken in Spain in the last tree years. For doing that, it is neccessary to study, first, the geostrategic situation and the risks for the global security. Aftewards we see the basic theoretical conceptions about this situation. It is see, between others, topics like "Revolution on Military Affairs» or "Transformation», doing a critical analysis of them. Finally the paper do a deep study of the National Defense constitutional-Act (5/2005), the All-volunteer force Act $(8 / 2006)$, and the CO and NCO career Act, wich is in the way to be approved by the Parliament.

Key words: Spain; defense and national security; armies; all-volunter force; military career.

\section{INTRODUCCIÓN GENERAL}

"(...) El Ejército, en tiempo de paz, no tiene más misión que instruirse para la guerra; pero cuando llega la guerra, si la organización del ejército no es todo lo perfecta que cabe en lo humano, no sirve para nada, y todo lo que se ha venido gastando y produciendo y trabajando en los años de la paz es absolutamente perdido; esto no pasa en ninguna otra institución del Estado. Se me dirá: la universidad española es mala. Sí; mala o regular; pero para algo sirve; podrá enseñar mejor o peor, pero algo enseña; los hospitales no son buenos, pero algunos enfermos acogen; podrán ser mejor o peor atendidos, pero a algunos curan. Esto no pasa con las instituciones militares; o son perfectas o tienen plena eficacia el día de la guerra lo que se ha hecho con ellas es pérdida seca y sacrificio inútil» ${ }^{1}$.

\section{Justificación de este estudio: las recientes reformas militares} en su contexto

Recientemente se han aprobado varias leyes vertebrales en la regulación de las Fuerzas Armadas (en adelante, FAS). Se trata, en primer lugar, de la nueva Ley Orgánica 5/2005, de 17 de noviembre, de Defensa y Organización Militar (LODNOM), que sustituye a la antigua de 1980. A continuación se aprobó la Ley 8/2006, de 24 de abril, de Tropa y Marinería. Y, muy recientemente, la Ley de la Carrera Militar (LCM) ${ }^{2}$. Junto con esas leyes, de importancia indudable, se han aprobado numerosos reglamentos de renovación de múltiples aspectos de la profesión militar. Toda la estructura de las FAS se ha visto, también, reformada: Real Decreto 787/2007, de 15 de junio, por el que se regula la estructura operativa de las Fuerzas Armadas; Real Decreto $416 / 2006$, de 11 de abril, por el que se establece la organización y el despliegue de la Fuerza del Ejército de Tierra, de la Armada y del Ejército del Aire, así como de la Unidad Militar de Emergencias; y, hace algo más de

1 M. AZAÑA, «Política militar: líneas generales de las reformas de Guerra y creación del cuerpo de suboficiales (sesión de Cortes del 2 de diciembre de 1931)», en Obras completas, tomo II (Una política en el poder y en la oposición), Ediciones Oasis, México, 1966, pág. 95.

2 Aprobada el día 13 de noviembre de 2007 por el Congreso. 
tiempo, Real Decreto 912/2002, de 6 de septiembre, por el que se desarrolla la estructura básica de los ejércitos.

Todo este proceso hay que enmarcarlo dentro del periodo de revisión estratégica que se inició con la ambiciosa, algo rompedora, Directiva de la Defensa Nacional 1/2000. Lo que ahí se expuso se plasmó en la «Revisión Estratégica de la Defensa» (en adelante, $R E D$ ), de 2003. Se trata de un documento de naturaleza muy singular, en ningún caso jurídica, pero de contenido muy interesante, del que hablaremos bastante, a pesar de haber sido «enterrado». Luego vino la Directiva de la Defensa Nacional 1/2004 (que sustituyó a la 1/2000) e inició el ciclo de planeamiento de la defensa en el que nos encontramos. Complejo proceso en el que las autoridades políticas marcan unos objetivos que, luego, la alta cúpula militar trata de aplicar, mediante documentos reservados para establecer la fuerza, los plazos, medios, etc., que han ido marcando las pautas bajo las cuales se ha ido llevando a cabo este periodo. En este marco, el Ministro ha anunciado una «Propuesta de Objetivo de las Capacidades Militares» $(\mathrm{OCM})^{3}$. Propuesta política, que se ha querido hacer pública - cosa que raramente ocurría-, pero que forma parte de los documentos (objetivos, directivas, etc.) que siguen a la DDN en el segundo año de planeamiento de la defensa. Debemos entender la actual LODNOM como una heredera de la DDN 1/2004 que, por los avatares políticos conocidos, es una respuesta aquilatada a los efectos que se achacan a la DDN 1/2000. Por todo ello estudiaremos esas leyes, pero lo haremos situándolas dentro de las líneas de la política de defensa y, como ahora veremos, especialmente en el marco del panorama de cambios en la seguridad y los asuntos militares. De otro modo, el estudio de las puras normas resulta estéril, falto de conexión y de interés.

\section{La defensa y organización militar y el Derecho administrativo}

Para encontrar la razón de la ubicación de este estudio en el ámbito del Derecho administrativo nos tenemos que situar en un plano más profundo. Esa razón se encuentra en que la misión primaria, la justificación última de un Estado es la salvaguarda de los ciudadanos que lo forman y, con ello, la supervivencia de su cultura y forma de ver el mundo, su historia, etc. Y esto lo llevan a cabo las Fuerzas Armadas, o los ejércitos que las forman, en el marco de las misiones y con las formas que ese Estado defina. Se trata de

3 Documento presentado por el Ministro el día 4 de septiembre de 2007 como «Propuesta de Objetivo de las Capacidades Militares»(POCAM), derivado de la DDN 1/2004, y cuya finalidad se dirige a varios campos: 1) apoyo de las FAS a la acción del Estado; 2) mando y control integrados; 3) vigilancia y reconocimiento, obtención y elaboración de inteligencia; 4) movilidad y protección de la fuerza en un teatro de operaciones; 5) sostenibilidad de la fuerza en un teatro; 6) supervivencia y protección, y 7) superioridad en el enfrentamiento. Considero que se trata de una lista de objetivos en los que estamos en una situación francamente mejorable. En realidad, no aporta mucho a lo que ya apuntara la RED. 
una imperiosa necesidad, que puede no haber sido la causa única de la existencia de un concreto Estado, pero sí es fácil que haya sido una causa importante en su construcción. Puede haber sucedido que esta necesidad no se haya activado desde hace mucho tiempo; incluso que sea preciso rastrear en siglos pasados para encontrar el momento estelar en el que esto ocurrió, si es que fue solamente uno, que no suele ser el caso ${ }^{4}$.

No ha faltado un trato por parte de los estudiosos del Derecho administrativo a este fenómeno. Si bien los primeros tratadistas (COLMEIRO, GARCía Oviedo, SANTAMARÍA PAREdes, etc. ${ }^{5}$ ) dedicaron bastantes páginas al estudio de la "Administración militar» ${ }^{6}$, enmarcándola entre las funciones del Estado, tendremos que esperar a los años sesenta del siglo xx para su verdadera conceptualización por parte de GUAITA. Para este autor, la Administración militar constituye una «Administración especial», por estar dedicada - junto con Exteriores, la Administración judicial y la Hacienda- a la prestación de un bien uti universi, de un servicio público general «que a todos interesa», aunque se encuentre en estado de latencia o de «espera suasoria» ${ }^{7}$.

Con la aparición de la Constitución y la posición de las FAS en el artículo 8 (título preliminar) e, indirectamente, en el artículo 97 (sobre la organización del poder ejecutivo), se abrió un debate sobre el ser o la naturaleza jurídica de las FAS: ¿Son una Administración pública o una institución -incluso un poder- diferente de entre los muchos que existen en el Estado? La posición constitucional, que traía causa de una historia compleja y de una realidad acuciante, entorpecía esa catalogación. GuAITA, LóPEz RAMÓN y otros autores, sin perjuicio del carácter institucional de los ejércitos, convinieron en que estamos ante una Administración pública especial o, si se prefiere, singular ${ }^{8}$. En tiempos más recientes, PEÑARRUBia Iza y BlanQuer CRIADO han realizado unos completos estudios sobre todos los aspectos más cruciales de las FAS, desde un punto de vista muy jurídico y, en materia de derechos y libertades, sobre la base de una amplia jurisprudencia del $\mathrm{TC}^{9}$.

Al final y como simple conclusión de esta aproximación, se puede en-

4 Cuestión tratada en «La potestad regia de mando sobre las Fuerzas Armadas», en el libro VV.AA., La Monarquía Parlamentaria. Estudios sobre el Título II de la Constitución, Congreso de los Diputados, 2002; J. KeEGAN, Historia de la guerra, Planeta, 1994, in toto. En el fondo, dirá FERRILL, la guerra no es sino la evolución, cada vez más compleja en formas, medios y razones - cadena de justificaciones y métodos para exponerlas-, de la lucha individual por la supervivencia: A. FerriLl, Los orígenes de la Guerra (desde la Edad de Piedra hasta Alejandro Magno), Ediciones Ejército, EME, 1987; A. ToYnBEE, Guerra y civilización, Alianza, Alianza \& Emecé, 1976.

5 En otros lugares, también O. Mayer, M. Hauriou, L. Duguit, por ejemplo.

6 Un análisis completo de todo ello puede verse en F. LÓPEZ RAMÓN, La caracterización jurídica de las Fuerzas Armadas, CEC, 1986.

7 A. Guaita Martorell, Derecho administrativo especial, tomo I, Librería General, 1969 (sobre un artículo anterior escrito en esta REVISTA en 1965).

8 En los libros citados, de los que puede hallarse un somero repaso, con todos los autores que han participado, en las primeras páginas de J. C. Alli TurRILlas, La profesión militar. Análisis jurídico tras la Ley 17/1999, INAP, Madrid, 2000.

9 J. Peñarrubia Iza, Presupuestos constitucionales de la función militar, CEPC, 2000, y, también, más dirigido al estatuto del soldado de reemplazo, M. BLANQuER, Ciudadano y soldado, Civitas, 1996. 
marcar el funcionamiento estructural y jurídico de la organización que apoya a la fuerza de los ejércitos — que cuando está activada se rige por todo un sistema jurídico-operativo propio- dentro del ámbito del Derecho administrativo, aun con sus peculiaridades, grandes, por tratarse de una singular institución en el sentido dado por HaURIOU.

\section{El PANORAMA PREJURÍDICO DE LA SEGURIDAD Y LA DEFENSA}

1. Viejas y nuevas guerras

\subsection{Nuevos conflictos, viejos problemas.}

Según un esquema que se ha hecho clásico, proveniente de TOFFLER, las guerras obedecen, aunque también son causa, de las generaciones de producción y sociedad que han ido existiendo ${ }^{10}$. Así, las guerras de la primera generación serían aquellas que se realizaban con armas blancas, que durarían hasta bien entrada la Edad Media. Posteriormente vinieron las guerras de la segunda generación, en las cuales se va produciendo una paulatina evolución mediante diversos sistemas: la pólvora, los cambios en la organización de los ejércitos modernos, las comunicaciones, la artillería de campo, etc. Desde, aproximadamente, la primera guerra mundial aparecen las guerras de la tercera generación, marcadas por la industrialización productiva, el poder aéreo y la enorme masa de hombres. Ahora estaríamos, ya, en las guerras de la cuarta generación (4GW), caracterizadas por una gran complejidad, variabilidad y fugacidad, pero de las que aún hay que descubrir su cañamazo (HoFFMAN) ${ }^{11}$.

En cualquier caso, nada es tan nítido y tan claro como quisiéramos. Tanto en África como en América se han dado durante el siglo xx verdaderas guerras de la primera generación, aunque ayudadas de sistemas de la segunda generación e, incluso, de la tercera. Estados con ejércitos de segunda generación (EE.UU., Francia, Inglaterra) combatieron durante el siglo XIX con ejércitos tribales de la primera. Durante el siglo XX esos países, y mucho otros, en la tercera generación bélica han combatido en guerras contra fuerzas que podrían denominarse casi de la primera generación: Vietnam, Somalia, Egipto, etc. Y en ambas situaciones, en alguno de estos lugares, excepcionalmente, además han perdido. En los conflictos actuales es fácil que concurran fórmulas de varias generaciones de guerras. Parece muy difícil que nos encontremos un conflicto cuasi simétrico, como los que pudieron verse en Europa desde el siglo x hasta el Xx. Lo que sí vemos, cada vez con más frecuencia, son conflictos asimétricos ${ }^{12}$.

10 A. Toffler, La tercera ola, Plaza \& Janés, 1999 (original de 1984).

11 F. Hoffman, "Neo-classical counterinsurgency?», en Parameters, Summer 2007, págs. 71 a 87.

12 J. JoRdán y J. L. Calvo, El nuevo rostro de la guerra, Eunsa, 2005, págs. 41 y ss. 
Ahora, además, tenemos otra disyuntiva: utilizar los ejércitos para lo que son, o dejar que la guerra la conduzcan mercenarios, señores feudales modernos y guerrillas insurgentes, en tanto nuestros ejércitos se dedican a una paz que no es tal. Grupos en los que no hay mujeres, ni normas administrativas de ascenso, destino o bajas por enfermedad o por maternidad, ni una ética profesional, ni disciplina como tal, que no obedecen las leyes de la guerra, ni les importan. Grupos que no han sido domesticados por el Estado, monopolizador de la violencia legítima (Max WeBER) ${ }^{13}$. Como hemos tratado en otro lugar ${ }^{14}$, la aparición de fuerzas mercenarias ( «contratistas de seguridad») de todo tipo, de un lado, y, de otro, el descontrol de las fuerzas militares de muchos lugares bajo fenómenos guerrilleros, señores de la guerra, terroristas, etc., están siendo — entendidos conjuntamente- un verdadero golpe en la naturaleza del sistema militar actual. Para MüNKLER, esa conjunción involuntaria a finales del siglo XXI de esos factores establece una clara ruptura de la domesticación que el Estado moderno — creado, como Estado nacional, mediante la movilización de sus ciudadanos ${ }^{15}$ - hizo de sus guerreros y de la violencia ${ }^{16}$.

Además, existe una reducción paulatina del número de soldados y de equipamiento militar, pero una mayor complejidad de esos sistemas y, por tanto, de sus exigencias de formación y utilización para los primeros. El coste se ha incrementado en tal grado que su compra, amortización y uso se hacen especialmente exigentes en los ejércitos que se basan en la tecnología ${ }^{17}$. Esta tecnificación de medios y funciones militares ha implicado, casi siempre, una mayor demanda de técnicos y expertos civiles que los utilicen y ha exigido una tecnificación de los estudios de las carreras militares, lo que ha llevado, con facilidad, a la decisión de profesionalizar todos los escalones de la profesión militar ${ }^{18}$. Además, la nueva situación de riesgos y ame-

13 H. MünKLER, Viejas y nuevas guerras. Asimetría y privatización de la violencia, Siglo XXI, 2005, págs. 81 y ss.

14 J. C. Alli TurRILlas, «La desnacionalización de los ejércitos (Privatización y externalización en las Fuerzas Armadas. El retorno al modelo tardo-renacentista)», en Boletín de Información del Ministerio de Defensa, núm. 285, 2004.

15 H. Schulze, Estado y nación en Europa, Crítica, 1997, in toto, y J. F. C. Fuller, La dirección de la guerra, cit., págs. 29 y ss.

16 Existe una privatización total, mediante la contratación de servicios mercenarios. Esto es una realidad palmaria sobre la que no voy a extenderme. Me remito al completo y agudo libro de P. W. SINGER, Corporate warriors. The rise of the privatized military industry, Cornell University Press, 2003. Ejemplo de todo ello es la situación de los EE.UU. en Irak; puede verse en G. Schumacher, A bloody business. America's war zone contractor and the occupation of Irak, Zenith Press, 2006. Para una visión más amplia y bastante más crítica, R. Y. Pelton, Licensed to Hill. Hired guns in the war on terror, Tree Rivers Press, 2007.

17 Los ejércitos o fuerzas irregulares que han optado, en cambio, por el combate de segunda generación, bajo paradigmas de la cuarta, son mucho más baratos, pues juegan al ratón y al gato con medios mucho más pobres: armas ligeras, antitanques, misiles básicos, vehículos normales, etc. Pero no tienen miedo a la muerte, miedo que tratan de ocultar y evitar los ejércitos occidentales (H. MüNKLER, Viejas y nuevas guerras, cit., págs. 155 y ss.).

18 Tal y como apuntaba y servía como base de trabajo al pionero estudio en materia de sociología militar de M. JANowitz, El soldado profesional (1962), Ministerio de Defensa, 1989 , in toto. 
nazas, la reducción del grosor de las Fuerzas Armadas, han exigido, también, un redespliegue espacial y la reordenación de los recursos de la fuerza militar, con nuevas doctrinas de empleo para su actividad. Predomina la funcionalidad, integración y conjunción.

\subsection{Visiones teóricas sobre el nuevo entorno de seguridad.}

En sus largos viajes por un tercer mundo en una profunda crisis que en estos últimos años se ha acrecentado, el periodista-politólogo Robert KAPLAN nos anunciaba en 1994 una «anarquía que viene». Señala cómo una superpoblación tremendamente joven, unida a una importante desestructuración social (familiar, estatal, política), junto con la ausencia de educación, de expectativas sociales y laborales, y todo ello en un ambiente de epidemias, pobreza, delincuencia, falta de agua, desastres ambientales, y una profunda y corrosiva corrupción política, son causas de que muchos países se conviertan en Estados fallidos y generen una enorme inseguridad que la globalización extendería ${ }^{19}$. Todo ello generó una suerte de «bombas de relojería» regional que, luego, los vasos comunicantes de la globalización trasladan irremediablemente, llevando sus efectos mucho más lejos de lo que antes, en tiempos pasados, hubiese sido posible ${ }^{20}$.

La guerra contra el terror en la que parece haberse embarcado la superpotencia, como veíamos, encubre, en realidad, una reformulación de la guerra contra la insurgencia y los terroristas que utilizan ese terror. El mismo KAPLAN nos señala cómo están actuando los ejércitos norteamericanos en una gran cantidad de lugares (Colombia, Filipinas, Liberia, Marruecos, Bosnia y Kosovo, Afganistán, etc.) para intentar poner coto a este nuevo tipo de anarquía y de guerra, dando paso a una nueva forma de ver su actividad. No se trata tanto de conquistar como de mostrar a esos países las fórmulas militares y policiales para combatir esos problemas ${ }^{21}$. Pero no se trata de una lucha fácil. Así, a resultas de ello y de las inercias de un ejército todavía muy centrado en la «batalla (acorazada) decisiva» y con formas muy burocráticas, EE.UU. - junto con sus aliados más directos- parece haber perdido buenas oportunidades de cerrar frentes, cual es el caso de Afganistán ${ }^{22}$.

La politóloga inglesa M. KALDOR señala varios puntos neurálgicos de las

19 R. D. KAPLAN, Viaje a los confines de la tierra, 1999, y La anarquía que viene, ambos en Ediciones B, 2000. Posteriores rutas por Asia, los Balcanes y otros lugares iban corroborando su análisis de la realidad: R. D. KAPLAN, Rumbo a Tartaria, Ediciones B, 2000, y Fantasmas balcánicos. Viaje a los orígenes del conflicto de Bosnia y Kosovo, Ediciones B, 1996.

20 Pero si bien su análisis era certero, luego quizá mostraba una tendencia a exagerar sus efectos derivados y, con ello, optaba por soluciones demasiado drásticas, exclusivamente militares y poco dadas a una intervención policial limitada, o a la diplomacia con fuerza (así puede verse en R. D. KAPLAN, El retorno a la antigüedad. La política de los guerreros, Ediciones B, 2002).

21 R. D. KaPlan, Gruñidos imperiales..., cit., in toto.

22 W. Clark, Qué ha fallado en Irak, Crítica, 2004, págs. 169 y ss. 
nuevas guerras. En primer lugar, dirá que la nueva guerra no es tanto un nuevo tipo de ejército, o de forma de luchar, cuanto un nuevo molde de lucha. La guerra es, hoy día, no un enfrentamiento entre naciones o pueblos, sino entre valores cívicos, universalistas, plurales y multiculturales que tratan de abrirse paso en la nueva sociedad y los valores excluyentes y particularistas propios de los fundamentalismos nacionales, religiosos, tribales o del tipo que sean. De ahí se deriva, por lo tanto, el cambio en las formas de lucha, en las estructuras militares y los ejércitos y sus armas. En segundo lugar, insiste en que es un factor determinante el cambio en la economía global y, con él, por tanto, la globalización de las economías de guerra. En definitiva, para la autora, es posible que exista una «revolución en los asuntos militares», pero ésta no es todo, sino que "se trata de una revolución en las relaciones sociales de la guerra, no en la tecnología, aunque esos cambios en las relaciones sociales estén influidos por la nueva tecnología y hagan uso de ella (...). Creo que las nuevas guerras deben interpretarse en el contexto conocido como globalización. Por tal entiendo la intensificación entre las interconexiones políticas, económicas, militares y culturales a escala mundial» ${ }^{23}$.

Hay un verdadero cambio de paradigma existencial y nuevo tipo de sociedad pugna por abrirse paso, obstaculizado por las consecuencias exacerbadas del antiguo modelo nacional. Una nueva era pluricultural, global y dirigida por las leyes internacionales, los derechos humanos y las instituciones supranacionales. Por eso surge el conflicto entre el modelo antiguo y el nuevo ${ }^{24}$. IGNATIEFF, con análisis muy ponderados, considera que la realidad exterior está obligando a unos profundos cambios en la manera que Occidente tiene de entender un mundo que no acierta a comprender. Esta realidad - en una evidente simplificación de sus ricas matizaciones- es muy compleja: guerras civiles, hambrunas, ausencia de ejércitos «oficiales», luchas de "guerreros» sin códigos de honor, mesianismos nacionales y religiosos. Occidente se encuentra en una suerte de encrucijada, en una posición esquizofrénica. Nuestros códigos jurídicos y morales nos obligan a actuar por salvaguardar los derechos humanos y la sociedad y la prensa - con mayor o menor acierto y verdad - nos exigen solución y respuesta al mostrarnos esos terribles problemas. Pero, a la vez, existe un enorme miedo a volver a actuar como países «coloniales» $\mathrm{o}$ «imperialistas» —rechazado en muchos lugares en los que habrían de entrar, además-, así como, en mayor medida, a la posibilidad de tener numerosas bajas propias y ajenas ${ }^{25}$. Y ello por no hablar del coste de las intervenciones. En este panorama, lo que los psicólogos denominarían "disonancias» generan unas disfunciones terribles. Se llega así a la búsqueda de una forma aséptica de guerra (interven-

23 M. KALdor, Las nuevas guerras, Tusquets, 2001, págs. 17 y 18.

24 Para esta autora es posible mantener, en el fondo, una visión optimista y alentadora por cuanto considera que el bien común internacional y el control de la economía acabarán permitiendo superar muchos de estos conflictos. M. KALDOR, Las nuevas guerras, cit., págs. 195 y ss.

25 M. IgNATIEFF, «El atractivo de la repugnancia moral», en El honor del guerrero, Paidós, 2002, págs. 132 y ss. 
ciones quirúrgicas, se denominan). Ilustrativo es, para IGNATIEFF, el panorama frío, televisivo y alejado que supuso la guerra de Kosovo. Es muy ilustrativo, dirá, que se trató de la primera guerra virtual — para los occidentales, pues no parece haberlo sido para albanokosovares y serbios- ${ }^{26}$.

LUTTWAK señala que el nuevo tipo de guerras al que se enfrenta el mundo, al haber cambiado de paradigma, no permiten una victoria decisiva sobre un ejército enemigo definido y sobre una sociedad civil, de tal manera que se firma una paz y se acaba. Se trata de guerras étnicas, religiosas, por bienes esenciales, civiles. En todo caso, muy complicadas, insidiosas, que tienden a atascarse y enfangarse en lugares poco atractivos, en los que las poblaciones son pobres y los recursos también. En esta situación no cabe la batalla heroica, brillante, a resultas de la cual las unidades uniformadas de gala hacen entrega de las armas rendidas en tanto los vencedores condecoran a sus hombres valerosos. Son lo que denomina "guerras post-heroicas». Y lo hace por un doble motivo. El primero, porque se pueden adjetivar como guerras sucias, complicadas, repletas de acciones poco resolutivas, frente a la aparente gloria de batallas con pendones y trompetas del pasado. Pero, en segundo lugar, porque nuestra sociedad - profundamente postheroica - tampoco está dispuesta a sufrir el coste humano, económico y social de esas guerras ${ }^{27}$.

Todos estos peligros han llevado, en ocasiones, a propuestas drásticas. Por todo ello, dicho autor considera que con esa moda «moralizante» de Occidente mediante la interposición humanitaria, y la protección de los pueblos, no sólo no se solucionan los problemas, sino que se acrecientan, al no dejar que sigan su curso natural. Así, señala que «las guerras deben llegar a su fin», en el sentido clausewitziano de que hay que dejar que alguien asuma una victoria decisiva, sin entrar a valorar el coste que ésta tenga ${ }^{28}$.

26 M. Ignatieff, Guerra virtual. Más allá de Kosovo, Paidós, 2003, especialmente págs. 151 y ss. Todo esto genera una serie de peligros a los que hemos llegado no mucho más tarde y que, de nuevo, nos plantean interrogantes filosófico-morales muy interesantes: ¿Cuándo estamos legitimados para intervenir? ¿Cuánto podemos hacer por detener el conflicto y encauzar la paz? A ello se le une, también, que muchas de estas nuevas formas de violencia global saltan los muros fronterizos y se sitúan en nuestras mismas sociedades, mediante ataques terroristas o mediante un deseo de destrucción de nuestro modelo social, que quisieran transformar. Ante ello: ¿Qué y cómo podemos hacer para evitar esos atentados o la presencia de fuerzas sociales e incluso políticas que buscan nuestra destrucción o transformación? Es decir, casi en el puro terreno procesal, aunque con grandes implicaciones morales: ¿Debemos aplicar nuestras garantías jurídicas a quienes tratar, precisamente, de destruirlas? ¿Hasta qué punto esta inaplicación no es el efecto buscado por ellos y una manera de autodestruirnos? Todos estos interrogantes son respondidos con una reconstrucción de la filosofía moral y política que realiza el propio autor y que permite tener las pautas para que los gobernantes sepan qué hacer ante las medidas de política interior, prisiones, espionaje, operaciones especiales, etc., en la "guerra contra el terror» y en las nuevas operaciones militares dirigidas a parar los golpes de este mundo desbocado. M. IGNATIEFF, El mal menor. Ética politica en una era de terror, Taurus, 2004.

27 E. LuTTWAK, «Towards a post-heroic warfare» $\mathrm{y}$ "A post-heroic military policy», en Foreign Affairs, núms. 75, julio-agosto 1995, y 74, mayo-junio 1995, respectivamente.

28 E. LuTTWAK, "Las guerras deben llegar a su fin (errores de una pacificación impuesta)», en Política Exterior, núm. 71, 1999, págs. 15 a 21. Otros han puesto de relieve cómo 
Es una idea que rechazamos como fin o medio, aunque apunte algunos aspectos certeros en su construcción. Estas consecuencias son el fruto de esa especie de esquizofrénica aproximación, «humanista» y «moralizante» de un lado, y de otro reacia - post-heroica-, a la intervención, sobre todo si no existen intereses económicos más o menos ocultos. Actuar así, cuando se hace, y no hacerlo en otras ocasiones que la moralidad exigiría lleva consigo muchas semillas de dolor, por lo profundamente incoherente que resulta actuar en unos lugares y no en otros, nos dice KENNEDY ${ }^{29}$. Otras propuestas van por el camino, señalado por KAPLAN, de actuar allí donde estos males se inician, a la guarida del lobo; llevar ahí su lucha, para evitar que se propague por Occidente Oc. $^{30}$.

El análisis más completo y certero, en mi opinión, lo ha realizado Herfried MÜNKLER. Para este profesor alemán, las nuevas guerras contienen muchos elementos comunes con las guerras de construcción de los países europeos durante los siglos XVI a XVIII ${ }^{31}$. Se trata, en un somero repaso, de guerras intrasociales, largas, complejas, con enorme afección a la población civil. Estas guerras se producen en los lugares y colonias, frecuentemente ricos en algún producto primario, aunque pobres y destruidos en el plano social. Lugares donde se solaparon los bloques políticos del siglo xx y que tienen mucho que ver con la economía globalizada, por cuanto sus contendientes, "a través de los canales de la globalización en la sombra, están vinculados de múltiples maneras con la economía mundial y extraen de ella los recursos necesarios para su prolongación». Florecen en ellas las bandas de guerrilleros-bandidos, los señores de la guerra, los contratistas privados, a veces las fuerzas de interposición y los campos de refugiados, en una amalgama de difícil comprensión. Las ideologías, tanto religiosas como políticas, no son determinantes, sino más bien un mero antifaz que oculta otros problemas. Sus líderes, por tanto, «utilizan la ideología para legitimar su lucha» ${ }^{32}$.

Los elementos clásicos del conflicto: su carácter político, la búsqueda de las batallas decisivas, unos contendientes más o menos identificables, el

esto se ha producido, por ejemplo, en la guerra de Kosovo y sus «fracasos», y son muestras de gran importancia para entender la situación actual de la OTAN y de los EE.UU.: I. H. DAALdER y E. O'HANON, Winning ugly: NATO's war to save Kosovo, Brookings Institute Press, Washington, 2000, y en las memorias parciales del general al mando de las operaciones militares de la OTAN, W. L. CLARK, Waging modern war: Bosnia, Kosovo and the future of combat, Public Affairs, New York, 2001. 2007.

9 D. KenNedy, El lado oscuro de la virtud... O cómo pervertir una causa noble, Almuzara,

$30^{\circ}$ R. D. KAPLAN, El retorno a la antigüedad. La política de los guerreros, cit., in toto.

31 Existían, entonces, contratistas de seguridad (condottas mercenarias), prestamistas de dinero y servicios (los asentistas). Los ejércitos eran, aún, una suerte de ejércitos nobiliarios a los que el Rey encargaba una misión, aunque en evolución hacia los ejércitos reales, que no nacionales, pues éstos no llegarán hasta el siglo XIX. El ejército no ocupaba el lugar, sino que se apoyaba en él y se aliaba con alguno de sus bandos, religiosos, étnicos, nobiliarios, para sacar partido económico del país conquistado (J. ANDÚJAR CASTILLO, El sonido del dinero. Monarquía, ejército y venalidad en la España del siglo XVIII, Marcial Pons, 2004).

32 H. MüNKLER, Viejas y nuevas guerras, cit., in toto. 
apoyo internacional a uno u otro bando, una economía «de guerra», han variado enormemente: violencia excesiva contra la propia población por todos los bandos (especialmente contra las mujeres y niños), uso del terrorismo, la insurgencia y guerra irregular, aprovechamiento de los recursos internacionales para el fortalecimiento de los combatientes en vez de para paliar el desastre humanitario consecuente, infiltración de empresas y contratistas de seguridad privados de otros países que tratan de sacar provecho, relaciones comerciales de los «señores» (en algún caso gobernantes más o menos legítimos) con la economía global. En ese contexto, los ejércitos tradicionales, lineales, sometidos a una disciplina y a las convenciones internacionales, movidos por Estados y bajo reglas de enfrentamiento más o menos precisas, son como paquidermos en un ambiente plagado de insectos. Y cuando lo hacen - como se ha visto- encuentran serios problemas en su intervención o en la decisión del conflicto.

Pues bien, continúa diciendo MÜNKLER, si hay algunas semejanzas, también son importantes las diferencias. Aquellos conflictos europeos se produjeron durante un periodo de cambio - una suerte de lenta revolución que va desde el Renacimiento hasta la llegada del Estado-nación- en todas las sociedades. Cambios sociales, religiosos, políticos, bélicos. Se trataba de guerras de «construcción nacional» en las que los demás reinos actuaban de una manera, digamos, ordenada por una visión - acertada o desacertada- de su geoestrategia política. Actualmente son guerras, más bien, de «desintegración» nacional, en lugares que fueron colonias y llegaron a contar con embrionarios Estados (muchos de ellos en el África subsahariana), así como en regiones perdidas en países subdesarrollados que pugnan por construir algo parecido a un Estado (Afganistán, Sudán, Camboya, Filipinas y muchos lugares de Iberoamérica). En estos conflictos, la violencia, los ejércitos, el apoyo de extranjeros, sean Estados, empresas o mercenarios, parecen estar supeditados a los intereses económicos que se diriman y al warlord que los maneje en cada momento.

No llama, así, la atención que, al socaire de las nuevas guerras e intervenciones militares, se esté abriendo paso un rejuvenecimiento de las ideas sobre las guerras justas provenientes de la doctrina que construyeran Suárez y De Vitoria, de la mano de $\mathrm{WALZER}^{33}$. Se reconstruye, con una visión más actual en su forma de presentarse y en los ejemplos, así una moral de la guerra (ius ad bellum et ius in bello) que favorezca - caso de producirseun clima de limitaciones. Así, es cierto que una hipotética guerra entre algunos países occidentales — con todos los matices que deberían hacerse en este ámbito- se parecería más a las guerras de las monarquías absolutas: limitadas, con una búsqueda de justificación moral, controladas, etc., que a lo que nos había acostumbrado el siglo xx. Pero el problema es que las verdaderas guerras nuevas en los lugares fuera de este ámbito político son, a todas luces, mucho más crueles que las antiguas (bien es cierto que en oca-

33 M. WALZER, Guerras justas e injustas. Un razonamiento moral con ejemplos históricos, Paidós, 2001 (sobre la edición de 1997), in toto. 
siones por intereses occidentales ocultos, señalaría BARBER) ${ }^{34}$. De ahí que sean, en ocasiones, el caldo de cultivo para acciones mercenarias, fuera del control estatal y mediático de los países occidentales; pues la doble moral es una situación presente, siempre, en el hombre. No cabe duda que el proceso de descolonización y el clima de relativismo - moral, personal, institucional, político y jurídico- imperante en nuestra sociedad parecen impedir llevarles lo único que podría darles una solución: el Estado y el Derecho ${ }^{35}$, aunque sea hecho dentro de un moderno y global modelo internacional y multilateralista.

Ante todo ello, FUKUYAMA apuesta, sin ambages, por una política de reconstrucción estatal, de tipo "protectorado». Y lo hace con la vista puesta en que los sistemas liberales han convertido esos lugares en las cloacas de la globalización. En su estudio nos recuerda lo que países como España, Inglaterra y Francia llevaron a cabo en tantos lugares: una burocracia, buenos niveles educativos, una cierta clase media, unos sistemas horizontales de relaciones entre la población. Luego, una torpe política internacional, un deseo de libertinaje mediante unos procesos poco claros de «democratización», lo destruyeron casi totalmente en muchos de esos lugares ${ }^{36}$. ZACCARÍA nos recuerda, además, cómo no es suficiente con establecer — como se ha tendido a hacer en algunos lugares - sistemas democráticos, en el sentido procedimental del término, si éstos no se imbrican con un adecuado «Estado de Derecho». Es decir, con un sistema protector de las libertades públicas y los derechos humanos bajo una sociedad civil fuerte. Hacerlo de otro modo es condenar al sistema a una autarquía que, aunque comience siendo efectiva, genera luego el pasto de la dictadura y de la revolución o la anarquía y el desastre ${ }^{37}$. Hay tantos ejemplos —empezando por la Alemania de Hitler o la Italia de Mussolini y siguiendo por Liberia, Nigeria y otros lugares - que citarlos resulta innecesario.

34 B. R. BARber, Fear's empire. War, terrorism and democracy, Norton \& Co., 2003, y N. CHOMsKy, El miedo a la democracia, Crítica, 2001.

35 M. IGNATIEFF, «El atractivo de la repugnancia moral», cit., pág. 220. Este autor coincide con el filósofo B. HENRY-LÉvy (en Reflexiones sobre la guerra, el mal y el fin de la historia, Suma de Letras, 2003, pág. 325) en que hay que evitar la tentación de no intervenir militarmente (pero con carácter humanitario y pacificador), fundamentada en excusas inocentes sobre la bondad. Esta idea de que Occidente debe evitar la tentación de la «no intervención», con un punto de vista más hobbesiano, tendente a justificar esa intervención no tanto por razones humanitarias cuanto de reordenación geoestratégica, es la propugnada por R. KaGAN (Poder y debilidad. Europa y Estados Unidos frente al nuevo orden mundial, Taurus, 2001) y KAPLAN en los libros citados.

36 F. FuKuYama, La construcción del Estado, Ediciones B, 2004

37 F. ZaCCARÍA, The future of freedom, Norton \& Company, 2004, págs. 29 y ss. 


\section{El cambio en los paradigmas o los nuevos enfoques de la seguridad}

\subsection{Revolución o evolución en los asuntos militares.}

Los Estados Unidos - y luego el resto de países occidentales- han buscado un paradigma que les permita entender a qué nos enfrentamos. Así, la compleja pero fulminante victoria de Irak de 1991 abrió paso al concepto de «revolución en los asuntos militares» (en adelante, RMA) ${ }^{38}$. Pero ésta chocó, muy pronto, con la insidiosa y pérfida realidad de las guerras de descomposición, la insurgencia y el terrorismo islamista. Más adelante, como veremos, surgió el concepto de "transformación», como una fórmula que parecía encajar mejor - y acertar en las jugadas - las piezas propias de un complejo juego de ajedrez en un tablero mundial. Ante todo ello se suscita la siguiente pregunta inicial: ¿Existe realmente una «revolución en los asuntos militares»? O, dicho de otro modo, ¿estamos ante una verdadera revolución o ante otro fenómeno que se le parece?

La primera objeción a la denominación «revolución» es la importante discusión en torno a si estamos propiamente en una RMA o ante una más amplia «revolución en los asuntos de seguridad nacional» ${ }^{39}$. Según muchos autores, estaríamos ante lo segundo, una revolución en la seguridad global. Lo que ha cambiado, como hemos visto largamente, es todo el panorama internacional y, con ello, también el uso de la violencia. Esto arrastra a los ejércitos y a otras muchas instituciones. Pero, claro, esta concepción es poco valorada por no dar a la cuestión una individualidad propia. Y sin esa individualidad esa doctrina no es tan vendible. Y, así, tampoco lo son los sistemas de armas que con ella se adjetiven. La segunda objeción podría parecer más sencilla: estamos ante un mero reflejo evolutivo de una evolución — quizá revolucionaria - de toda una realidad global cambiante. Pero, además de que esta objeción se deriva de lo anteriormente dicho, exige una mayor precisión. Porque toca la médula de la RMA: la utilización del sustantivo revolución o el aparente más simple de evolución. Y es que en torno a todo este debate existe una gran confusión, por cuanto se mezclan las dos claras formas de entender la propia palabra revolución.

KNOX y MURRAY hablan de dos fenómenos distintos cuando nos aproximamos a esta idea ${ }^{40}$ :

1) De un lado, las «revoluciones militares» que se producen cuando amplios fenómenos exteriores, políticos, sociales, tecnológicos —frecuente-

38 M. L. BROWN, «La revolución en los asuntos militares: la dimensión de la información», en www.afcea.org (junio 2007).

39 W. Murray, "Reflexionando sobre las revoluciones en los asuntos militares», en www.cgs.army.mil; VV.AA., "The revolution in military affairs», en www.ndu.edu, y, sobre todo, E. COHEN, «A revolution in warfare», en Foreign Affairs, núm. 75-2, marzo-abril 1996. Además, M. Knox y W. Murray, The dynamics of military revolution 1300-2050, Cambridge University Press, 2003.

40 M. KnOX y W. MurraY, The dynamics of military revolution 1300-2050, cit., págs. 176 y ss. 
mente la mezcla de todos ellos-, cambian la manera de entender los ejércitos y las formas de ejercer la fuerza, al fin y al cabo la guerra.

Estos hechos, al final, se ponen en relación con la existencia de un conflicto en cierto modo simétrico, puesto que no se pueden aplicar cuando la desproporción entre los contendientes es total, como, por ejemplo, en las guerras coloniales o en muchas guerras de conquista en la antigüedad. En esos casos, más que de revolución militar debe hablarse de desequilibrio de civilizaciones $^{41}$. Por lo tanto, hablar de revolución militar es buscar un punto de ruptura dentro de una cierta igualdad de condiciones. En segundo lugar, que las revoluciones sociales son hechos ajenos a la maquinaria militar y, por lo tanto, la sociedad que los sufra podrá, o no, ver sus consecuencias bélicas. Consecuencias que, además, podrán chocar con otras potencias o quedarse en los puros efectos internos ${ }^{42}$. Por lo que, aunque estas revoluciones sucedan, en numerosas ocasiones no veremos cuáles son sus efectos militares, o los veamos mucho tiempo después de su aparición social, cual fue el caso de la revolución industrial, que se vio reflejada, mucho tiempo después, en la primera guerra mundial.

Así pues, se ha hablado mucho de la «revolución militar» del siglo XVII, cuando se asientan las innovaciones producidas por el uso de la pólvora y, con ella, el nacimiento de los ejércitos modernos ${ }^{43}$. Si calificáramos a la pólvora como un invento revolucionario, parece aceptable también la objeción de que los cuatro siglos de desarrollo de su uso (del siglo XIV al XVII, cuando desaparecen casi completamente las unidades de armas blancas)

41 No habría propiamente, así, revolución en el choque entre Hernán Cortés y los aztecas (aunque sí entre los tlaxcaltecas, dirigidos por Cortés y su pequeña hueste, y los aztecas). J. DiAmond, Armas, gérmenes y acero. La sociedad humana y sus destinos, Debate, 1998, contiene varios capítulos dedicados a este tipo de «choque de civilizaciones». La efectividad de la forma occidental de hacer la guerra puede examinarse en el libro de V. D. HaNson, Carnage and culture..., cit., in toto.

42 En este sentido, no le falta algo de razón a Huntington cuando habla de «choque de civilizaciones». La profunda crisis por la que atraviesa un Islam que está redefiniendo su ideología, sus poderes, su presencia en los propios países musulmanes, tiene unos claros efectos exteriores. Estos efectos se ven amplificados por la existencia de una realidad internacional globalizada, por algunos conflictos entre Oriente y Occidente, por la aparición de numerosos grupos yihadistas, etc. Pero existe una suerte de «revolución» solapada que sí está teniendo efectos exteriores (J. JoRdán, Profetas del miedo, Eunsa, 2003).

43 Ha existido un amplio debate entre los historiadores anglosajones sobre la llamada «revolución militar moderna», centrada en torno a la pólvora, el orden cerrado y las reformas tácticas y escalafonales de Guillermo de Orange y Gustavo-Adolfo de Suecia (para todo ello debe verse el resumen que hace F. ANDÚJAR CASTILlo, Ejércitos y militares en la Europa moderna, Síntesis, 1999, págs. 15 a 38). En nuestra opinión, se trata, una vez más, de una evolución militar paralela a la social, silenciosa y larga, que comenzaría ya en el siglo XIV con el surgimiento de los Estados, la importación de la pólvora y la artillería, los ejércitos profesionales y el renacimiento de las formas grecolatinas de guerrear (como tantas otras formas culturales). Sí son una revolución para los imperios de América, pero no aquí, en Europa. Para apreciar, pese a los títulos, que estamos ante una evolución y no una revolución, pueden verse G. PARKER, La revolución militar. Las innovaciones militares y el apogeo de Occidente 1500-1800, Crítica, 1990, y "La revolución militar moderna: ¿Un mito?», en España y los Países bajos, 1559-1659, Rialp, 1986; R. QuATREFAGEs, La revolución militar moderna. El crisol español, Ministerio de Defensa, 1996; J. R. HALE, Guerra y sociedad en la Europa del Renacimiento (1450-1620), Ministerio de Defensa, 1990. 
permiten, más bien, hablar de una evolución en su uso. Y no precisamente de una evolución rápida.

Sí hubo, en el siglo XVIII, una auténtica revolución política y social, que tendría dos episodios principales (y luego muchos ecos): la Revolución americana y la francesa. Ambas revoluciones político-sociales sí tuvieron consecuencias militares revolucionarias, toda vez que generaron unos cambios militares enormes: ejércitos nacionales, masificación, potencia de fuego, grandes choques, guerras perpetuas y batallas interminables. Así pues, la Revolución francesa genera una revolución militar, por cuanto permite que un ejército de iguales características a los de sus vecinos, con una similar tradición y armamento, doctrina y potencia, les venza repetidamente, mediante una nueva elan y forma de empleo, una suerte de nueva moralización del ejército ${ }^{44}$. Posteriormente, estos cambios fueron evolucionando - con diversas innovaciones importantes, pero nunca revolucionarias-: durante la guerra de secesión americana, las guerras de Prusia y la primera guerra mundial, que es su cénit. Un cambio evolutivo más profundo, dentro de esa línea, se producirá en la segunda guerra mundial.

2) De otro lado, estarían los «cambios militares revolucionarios» ${ }^{45}$. En ellos, la estructura militar realiza transformaciones instrumentales, organizativas y, sobre todo, doctrinales y de mentalidad. Estos cambios le permiten llevar a cabo un enfoque «revolucionario» en la guerra, para así vencer al enemigo. Frecuentemente se trata de revoluciones de corta duración e intensidad, al menos hasta que el enemigo encuentra la simetría y puede, así, compensar la ruptura; esto, claro está, en el caso de no haber sido vencido por ese golpe "revolucionario» ${ }^{46}$. Para ser efectivos, esos cambios deben cumplir una serie de requisitos que se rastrean en todos los que se han catalogado como tales cambios ${ }^{47}$ :

44 Muy ilustrativo de todo ello es el libro de C. ARDANT DU PICQ, Estudios sobre el combate (1865-1869), Ministerio de Defensa, 1988, y M. KNOX, "Mass politics and nationalism as military revolution: the French revolution and after», en The dynamics of military revolution 1300-2050, cit., págs. 57 y ss.

$45 \mathrm{O}$ «revoluciones en los asuntos militares», que sería la traducción más textual, pero que, creo, no obedece realmente a lo que se quiere significar.

46 Durante la guerra franco-prusiana los franceses tenían las primeras mitrailluses, pero no supieron aprovechar su efecto demoledor en primera línea. En la primera guerra mundial, los contendientes trataron de buscar medios para romper la simetría. Así, los alemanes utilizaron ataques con gas y los británicos introdujeron el «tanque» o carro de combate. Al no tener la doctrina de uso adecuada, en ambos casos, la ruptura inicial fue absorbida en cuestión de días y no llegaron a ser revolucionarios. En la segunda guerra mundial, en cambio, el portaviones sí produjo esa ruptura en la guerra del Pacífico: Estados Unidos acabó derrotando a la poderosa flota nipona, pues tenía detrás toda la doctrina de guerra aeronaval que se había fraguado en Estados unidos desde los años veinte. Y el carro de combate - en combinación con infantería, artillería y aviación; así como de otros muchos factores ideológicos que sería largo tratar- consiguió la ruptura que permitió a Alemania conquistar Francia, Polonia y media Rusia en cuestión de semanas o meses. Para todo ello, VV.AA. (dir. P. PARET), Creadores de la estrategia moderna. Desde Maquiavelo a la era nuclear, Ministerio de Defensa, 1986, voces correspondientes a G. Dohuet, B. Mitchell y Tedder.

47 M. Knox y W. MurRaY, The dynamics of military revolution 1300-2050, cit., págs. 178 y ss. 
- Lo determinante no es la tecnología, sino su modo de utilizarse o la adopción de un modo efectivo y rupturista de usarla y aprovechar su ventaja. Es decir, es una cuestión de cambio «intelectual», más que de cambio material.

- Estos cambios militares revolucionarios han surgido para resolver problemas actuales y reales, normalmente mediante la evolución en aspectos que ya estaban funcionando, pero a los que se da un giro «copernicano» en su uso (vgr., el carro de combate).

- Son revolucionarios cuando se asientan en un modo innovador y ágil de entender la realidad, cuando han surgido en un ambiente de análisis profundo, prácticas constantes de nuevas fórmulas y se ha permitido su despliegue en todos los niveles de la cadena de mando ${ }^{48}$.

- La revolución opera en el terreno de la táctica y las operaciones, pero la estrategia necesita otras reglas para que un cambio revolucionario sirva para ganar la guerra. De ahí que muchos cambios revolucionarios hayan cambiado el transcurso de batallas, incluso de guerras, pero no el devenir de la historia o la victoria final de la guerra ${ }^{49}$.

Como ejemplo de este tipo de «cambios» se puede poner la aparición del binomio formado por el fusil de aguja-repetición y el cartucho metálico. Así, la gran potencia y movilidad del ejército prusiano en sus victorias sobre Austria, Dinamarca y Francia en el siglo XIX. En la vuelta a la guerra móvil de los años 1917-1918 del frente occidental se aprecia como una pequeña revolución "táctica» por innovaciones específicas en el uso de la artillería, radio, observación aérea y otros recursos que habían existido desde antes pero... sin entenderlos; en ese momento se aprende cómo aprovecharlos y ello lleva a la ruptura final sobre el ejército de Alemania. La blitzkrieg en Francia es posible por una adecuada utilización de un cambio militar «revolucionario»: la utilización del trinomio carro de combate-infantería mecanizada y aviones de ataque a tierra. Y aun cuando no sirva, después, para ganar la guerra final, este cambio se aprecia porque, en 1940, Francia supe-

48 «En nuestros días, el combate exige una cohesión moral y una solidaridad más poderosas que en cualquier época pasada» (C. ARDANT DU PICQ, Estudios sobre el combate, cit., pág. 85). La ampliación del campo de batalla, con el descontrol que esto supone para el mando (pensemos que Wellington o Napoleón casi controlaban visualmente todo el teatro de operaciones), exige una mayor necesidad de iniciativa táctica y operacional por parte de los mandos intermedios. Éste fue el gran éxito de la organización que Schieleffen, Molkte y Von Seeckt hicieron del ejército alemán. Lo mismo harán, luego, en el ejército de Israel, como se refleja en su gran adaptabilidad y capacidad de choque, absorción y ataque durante la Guerra de los Seis Días y la de Yom Kippur (VV.AA. - dir. P. PARET—, Creadores de la estrategia moderna..., cit., voces de esos generales y la reforma del Estado mayor prusiano; C. Herzog, La guerra del Yom Kippur, inédita, 2005). Estados Unidos, en la actualidad, trabaja en una monitorización de cada soldado, de tal manera que todo lo que él vea y perciba en el campo de batalla se traslade, on line, a la cadena de mando. Con todo, insiste mucho en la iniciativa del soldado y de los jefes de pelotón y sección, imitando el ejemplo de los centuriones romanos y de los suboficiales y generales alemanes de la segunda guerra mundial.

49 C. S. GRAY, Weapons don't make war..., cit., nos lo expone con gran cantidad de datos y fórmulas para entenderlo. 
raba a Alemania en medios acorazados y posición defensiva, pero no sabía cómo aprovecharlos frente a esa revolucionara doctrina germana. Lo mismo ocurre durante la Guerra de los Seis Días y en Yom Kippur, donde Israel se enfrenta con formas revolucionarias a fuerzas superiores y con medios más modernos ${ }^{50}$. La derrota final de Alemania en 1945, o la derrota política de EE.UU. en Vietnam, muestran cómo el último de los aspectos antes dichos es así: estos cambios técnico-táctico-doctrinales «revolucionarios» pueden verse incapaces de determinar la victoria total ${ }^{51}$.

Es quizá posible que, con el paso de los años y una vez se hayan decantado muchos de los actuales avances tecnológicos, se denomine a esta época histórica que comienza hacia los años ochenta como la «revolución informática». Parece que este periodo tiene evidentes paralelismos con lo que, históricamente, se ha conocido como la "revolución industrial» de finales del siglo XVIII (carbón, vapor, manufacturas, etc.), que generó una revolución social y muchos cambios políticos e intelectuales. Pero toda revolución de un sector social - como lo es el militar o, más ampliamente, el de la seguridad y defensa- suele ser el reflejo, en su caso, de una revolución más global y profunda. Pues, de otro modo, cualquier avance importante en la sociedad, y los ha habido en gran cantidad, sería susceptible de ser adjetivado como revolucionario.

Y, en lo militar, siempre hay un cambio importante cuando un ejército vence a otro igual o similar, es decir, en un conflicto simétrico, como se ha dicho. MURRAY recoge hasta once «revoluciones militares», algunas con una duración de horas (pues dieron el vuelco en una batalla), otras de años o de siglos (como la pólvora) ${ }^{52}$. ¿Es esto aceptable desde el punto de vista inte-

50 En efecto, de poco sirven unos mejores medios si no se sabe cómo utilizarlos o, mejor, si no se sabe cómo aprovechar el éxito (esto ocurrió con el gas y el carro de combate en la primera guerra mundial). Pues las innovaciones técnicas requieren innovaciones operativas (tácticas, operacionales o estratégicas) y nuevas soluciones organizativas que permitan su mejor explotación (fue el caso del modelo blitzkrieg de la segunda guerra mundial). De modo que con medios técnicos inferiores utilizados con moldes conceptuales superiores se puede ganar una guerra (caso de los israelíes en las guerras señaladas): T. N. DuPUY, $L a$ comprensión de la guerra. Historia y teoría del combate, EME, 1990, pág. 281, entre otras; también, E. COHEN, "A revolution in warfare», en Foreign Affairs, cit., págs. 37-54.

51 Al no tener una estrategia buena, Hitler acaba perdiendo todos los lugares en los que había ganado la revolución táctica de su forma de hacer la guerra: A. HiLlgrubER, $L a S e-$ gunda guerra mundial. Objetivos de la guerra y estrategia de las grandes potencias, Alianza Universidad, 1982.

52 MurRAY (cit., supra) clasifica alrededor de once revoluciones militares: el arco, la pólvora, las fortificaciones, las reformas tácticas, la sanidad, la inteligencia, etc. Examinándolas fríamente se aprecia que muchos de esos episodios son, realmente, puras evoluciones - que ya es bastante-, en tanto que otros son meros reflejos de las paralelas revoluciones civiles. Es posible afirmar que una revolución global es un fenómeno interterritorial, algo prolongado en el tiempo y multifactorial. De tal manera que a la revolución industrial - como la máquina de vapor, el carbón y la manufactura en el siglo XIX - en el terreno de la tecnología, le corresponde otro fenómeno geográfico: la expansión de la ciudad y los descubrimientos coloniales; uno social: el surgimiento de la burguesía; otro político: la división de poderes y la participación de la ciudadanía (la independencia americana y la Revolución francesa); natural: avances médicos y naturales, el evolucionismo, etc.; y militar: ejércitos 
lectual? ¿No estaremos más bien ante meros cambios parciales? Como es lógico, por esa misma razón, cualquier avance nuevo dentro de ese marco de cambio profundo sería revolucionario. Pero, simple y llanamente, se trata de una evolución típica del normal transcurrir vital, aunque quizá, en un posterior análisis histórico, se tenga una percepción y, también, una complacencia mucho mayor con esos cambios.

Efectivamente, muchos de los cambios sociales, tecnológicos y en el conocimiento que se están produciendo tienen una enorme incidencia en el terreno bélico y, por ende, en el de la seguridad y la defensa, toda vez que están transformando todo lo que tocan. El Estado nacional, cobijo del actual modelo de ejército, está en crisis. No se trata sólo de la existencia de un cambio en la utilización del ejército (misiones de intervención humanitaria, operaciones policiales, etc.) o de una transformación de su actuar al hacerlo con otros (Euroejército, etc.). Se trata de algo más profundo que afecta a todo el Estado, y por lo tanto a su ejército: pluralismo y multiculturalismo cultural, inmigración, desaparición de las fronteras y, consecuentemente, la propia situación y disposición de su fuerza armada. En efecto, la propia UE demuestra una progresiva transnacionalización con una evidente pérdida de soberanía y el traspaso de las competencias estatales (nacionales) - muchas de ellas soberanas, como lo han sido históricamente la facultad de juzgar, el mando de sus tropas o la persecución criminal- a entes supraestatales, de lo cual esa institución es su ejemplo más evidente. Además, en sus respectivos ámbitos, también salta a la vista el Tribunal Penal Internacional y la OTAN ${ }^{53}$. De puro evidente, creo que no es necesario hablar de la revolución informática y tecnológica, así como de sus consecuencias sociales y comportamentales, que han sido causa del fenómeno conocido como globalización y que subyacen bajo todo lo antedicho. Según GIDDENs, «tal y como la experimentamos, es en muchos aspectos no sólo nueva, sino revolucionaria. Pero no creo que ni los escépticos ni los radicales hayan comprendido adecuadamente qué es o cuáles son sus implicaciones para nosotros. Ambos grupos consideran el fenómeno casi exclusivamente en términos económicos. Es un error. La globalización es política, tecnológica y cultural, además de económica. Se ha visto influida, sobre todo, por cambios en los sistemas de comunicación, que datan únicamente de finales de los años setenta» ${ }^{54}$.

Parece aceptable, por lo tanto, decir que existe una lenta y poco «revolucionaria» - por violenta- evolución global. Y que ésta obliga, también, a una continua evolución militar, ni más ni menos rápida que su homónima

nacionales, táctica napoleónica. Y a todo ello suelen seguir hitos simbólicos (toma de la Bastilla, la caída del muro o las imágenes visuales del 11-S). En este sentido comparto la visión relativista y moderada que propugna, con gran acierto y mesura, A. SANZ Y CALABRIA, "Otra visión de la Revolución en los Asuntos militares», en Ejército, núm. 727, octubre 2001, págs. 24-34.

53 Cfr. al respecto G. JAÚREGUI, «Estado, soberanía y Constitución: algunos retos del Derecho constitucional ante el siglo XXI», en Revista de Derecho Político, núm. 44, 1998, págs. 45-74.

54 A. Giddens, Un mundo desbocado, Taurus, 2000, pág. 23; para un estudio de las consecuencias de todo ello, véase también J. RIFKIN, La era del acceso, Paidós, 2000. 
social. Efectivamente, todas esas transformaciones están teniendo importantes consecuencias en los factores esenciales de la guerra: ofensiva/defensiva, espacio/tiempo de batalla, fuego/maniobra ${ }^{55}$. La realidad está transformando los moldes conceptuales, los cuales permitirán el mejor aprovechamiento de los medios técnicos. Los medios, las armas, los logros técnicos, pese a ser una evolución muy rupturista de medios anteriores (un misil tiene poco que ver con una bomba de caída libre), tomados por sí solos son inocuos en muchos casos, y lo importante es la utilización, modo y finalidad que se hagan de ellos. Si hay una revolución militar es siempre en el contexto de una revolución global, que ha sido determinada, en gran medida, por la evolución tecnológica. Por eso creemos que puede hablarse de una evolución militar, sin más matices, pues resulta suficientemente claro. Evolución, además, que pronto es alcanzada por otros, que recortan así su impacto evolutivo ${ }^{56}$.

\subsection{El «perpetuum mobile» de la «transformación».}

El concepto RMA quedó, en cierto modo, enterrado cuando se apreció que esa revolución era efectiva y apabullante en guerras simétricas o convencionales (como Irak 1991, Granada 1989, Panamá 1992 y Kosovo 1999), pero no resultaba todo lo determinante que se pretendía cuando se trataba del nuevo tipo de conflictos asimétricos en los que se combatía a formas militares de insurgencia urbana, a fanáticos muy ideologizados o a terrorismos muy implicados con la población local. Y ésta era la realidad que se comenzaba a apreciar progresiva y lentamente en las guerras post-heroicas de los Balcanes, de Chechenia, en Oriente Medio, Colombia, etc. ${ }^{57}$

El factor que subyace en los nuevos retos - algunos en forma de guerra, otros no- que tienen planteadas las FAS es el de una indefinición, indeterminación y, con ello, la dificultad para encontrar una forma de combatirlos. Se ha dicho que un ejército siempre está capacitado para ganar la contienda que ya pasó, merced al estudio que realiza de cómo transcurrieron sus batallas y la toma de decisiones que llevaron a ella o se tomaron durante su transcurso $^{58}$, pudiendo verse sorprendido por una nueva guerra con diferentes formas de combate. Ahora puede afirmarse que parece que ni siquiera sabe en

55 F. Alejandre Martínez, «La tecno-guerra que... ¿viene?», en Ejército, núm. 722, abril 2001.

56 M. L. BROWN, «La revolución en los asuntos militares: la dimensión de la información», en www.afcea.org.ar/publicaciones/ram.htm (junio 2007).

57 Análisis apuntados por los libros de KAPLAN que han sido citados más arriba. Eran análisis de una realidad existente, pero se optó, en vez de por una suerte de indirect approach (LIDELL-HART), por una línea dura, que es la que propugna ese mismo autor. Ahora parece volverse a una aproximación más medida.

58 Afirmación que es un apotegma clásico de la historia de la guerra. Su análisis más agudo puede verse en el excelente libro de R. G. REGAN, Historia de la incompetencia militar, Crítica, 2001 (sobre la edición de 1987). 
qué tipo de conflicto combatirá o qué tendrá que hacer, por lo que su adaptación a esa realidad desconocida y multiforme resulta aún más difícil ${ }^{59}$.

Surgió, así, la idea de «transformación» como un nuevo concepto-motor que guiase tanto la perpetua necesidad de cambio que tienen los ejércitos, especialmente el de Tierra $^{60}$, como la propia capacidad para adaptarse a esos cambios. Alumbrada en los Estados Unidos, la idea de transformación ha hecho correr ríos de tinta en numerosas publicaciones y ha sido objeto de estudio por numerosos grupos de trabajo más allá del océano ${ }^{61}$. Con frecuencia encontramos con que según quien la examine pondrá el acento en los ángulos que se limitan a su campo de actuación, de modo que es difícil encontrar una teorización abstracta de la transformación. Por lo que se nos aparece más como un concepto comodín que como una teoría completa. La idea de transformación, desde sus primeras definiciones, resulta algo etérea, pues hace relación no a una realidad, sino a un proceso de evolución en un contexto que resulta siempre cambiante ${ }^{62}$. Si el marco teórico de la RMA resultaba algo ficticio, aún parece más falto de fundamento el concepto teórico de la transformación. Veámoslo a través de una serie de interrogantes que esta revolución nos plantea:

¿No es, acaso, un ejército una de las instituciones que se mantienen en un estado de transformación perpetuo? La realidad demuestra que el "conservadurismo» que se ha predicado sociológicamente de la institución militar es una necesidad para fortalecerse frente a cambios exacerbados. Excesos que, como ha ocurrido en numerosas ocasiones, dificultan acometer las guerras con todo el equipaje preciso para una buena consecución. Máxime cuando todo ejército está siempre en "estado de alerta», lo que exige prestar atención a qué está ocurriendo —en palabras de Wellington- «al otro lado de la colina ${ }^{63}$.

¿Es realmente necesaria una perpetua transformación o es mejor sedimentar y experimentar los cambios? Dado que ejércitos como el nuestro no están en un continuo proceso bélico y que los cambios militares son, generalmente, muy complejos y costosos, es bueno decantar cuánto hay de útil y de estéril en ellos. Y eso bien puede hacerse «escarmentando en cabeza ajena». Y así, por ejemplo, la experiencia del (semi) «transformado» ejército Rumsfeld de EE.UU. en Irak está resultando de gran utilidad.

59 La idea de la transformación, además de para avizorar el futuro, trata de marcar el ritmo, para que los demás bailen al ritmo de la música que marque quien se transforma primero.

60 A. Cebrowski, Transformation Trends, conference to the Heritage Foundation, Office of Force Transformation, 2003 (www.oft.osd.mil).

61 Hay que pensar que incluso tienen dedicados varios organismos de la estructura de la defensa encargados de su estudio y aplicación (Center for Naval Analyses, The Force Transformation Office): VV.AA., Transforming defense: a current assessment and the road ahead, Conference Report, CNA Corporation, 2002 Annual Conference, Alexandria, 2003.

62 Una buena prueba son todos los textos que, al respecto, recoge C. DE ANTONIO ALCÁZAR, «Reflexiones sobre la transformación», en Ejército, núm. 788, noviembre 2006, págs. 66 a 73, y F. GonzÁLez REVUelta, "¿Sabemos de lo que hablamos cuando nos referimos al concepto de transformación?», cit., págs. 18 y ss.

63 B. Lidell-HaRT, El otro lado de la colina, Ediciones Ejército, EME, 1982. 
¿Resulta preciso transformar métodos y doctrinas que han mostrado la utilidad en diversos tipos de conflictos? Me explico, numerosos conflictos actuales muestran muchos paralelismos con conflictos asimétricos coloniales, independentistas y políticos de los siglos XIX y XX, e incluso antes ${ }^{64}$. En este caso lo que habrá que hacer es reevaluarlos o, mejor, transformarse mirando hacia atrás para ver qué puede ocurrir en adelante ${ }^{65}$.

¿Qué es, exactamente, lo que hay que transformar? Porque si, como muchas veces acaban los estudios sobre transformación, de lo que se trata es de adquirir nuevos medios adecuados para nuevos tipos de amenazas, entonces, bien podríamos hablar de modernizar, actualizar, mejorar, cambiar, adaptar, etc. En fin, de política de armamento, siempre compleja. Si hablamos de cambiar las estructuras, simplemente estamos haciendo referencia a una suerte de necesidad cíclica en los ejércitos: actualizar la fuerza a sus cometidos, revisar sus fines y medios y adaptarlos a las cambiantes realidades ${ }^{66}$.

Parece claro que bajo este concepto, como señalaba, se hace referencia a una necesidad de cambiar la mentalidad ${ }^{67}$. De tal manera que se trata de pasar todo bajo un nuevo tamiz y, por ello, el armamento, la organización, los sistemas y las doctrinas están sometidos a una luz sideral que hace nítido su uso: transformación. Pero ¿transformación a qué, para qué y cómo? Antes señalaba también que un sinónimo de esta idea de transformación es el de adaptabilidad, que así parece arrojar algo más de luz. Transformación es tener capacidad de adaptación. De acuerdo, pero, entonces, ¿por qué esta insistencia? ${ }^{68}$. También se hacía referencia a la idea de eficiencia absoluta del instrumento militar. Bien, ¿qué fuerza armada de una sociedad occidental, inundada en sus mercados de instrumentos y doctrinas eficientes, no quisiera ser ella

64 H. MünKell, Viejas y nuevas guerras..., cit., págs. 43 a 66.

65 A. Alcázar Segura, "El enemigo asimétrico», en Ejército, núm. 782, mayo 2006, págs. 6-15.

66 En esta idea limitada de transformación por cambio estructural no puede decirse que, precisamente, nuestro Ejército de Tierra esté «falto de experiencia», como atestiguan los cinco planes de modernización que ha sufrido desde 1975 (planes Meta, Reto, Norte-1 y Norte-2 y el actual, innominado, quizá, para evitar que su nombre fuese tomado como un acrónimo burlesco). Así, el plan Meta fue denominado «Mejor Estaba Todo Antes»; el plan Reto, «Reducir el Ejército de Tierra a 0»; el plan Norte, "Nos Ordenan Reducir Terminantemente Esto»...; sólo quedaba el plan Sur, "Supresión de las Unidades Restantes», y/o el Este, «Esto Se Termina».

67 Asimetría de enemigo y de conflicto, exige transformación de estructuras para combatirlo. Transformación, claro está, de las estructuras de la guerra fría y de posiciones, de defensa tradicional del territorio, hacia un modelo mucho más ágil y capaz, pero también combinado, como hemos visto, con medidas diplomáticas, económicas, políticas y policiales: GonzÁlez Revuelta, "¿Sabemos de lo que hablamos cuando nos referimos al concepto de transformación?», cit., págs. 19 y 20.

68 ¿Se debe, quizá, a una insana manía de las autoridades civiles de los Ministerios de Defensa al cambio, fiada en una sensación, poco seria, de que un ejército necesita estar en continua agitación, para no dormirse, o, peor aún, a una intención de evitar el «conservadurismo» que se presume como la forma tradicional, y casi única, de enfocar cualquier percepción por parte de los militares? 
misma igual de eficiente? Más aún, como han reconocido muchos militares, la eficiencia puede ser una enemiga mortal de la eficacia en combate.

La historia demuestra que la efectividad de un cambio "transformador» - un invento revolucionario militar, dirían los citados KNOX y MuRRAY - en el equipamiento militar (el fusil de chispa, la bala minié, el cartucho metálico, la radio, la ametralladora, el carro de combate, el helicóptero, etc.) tiene un impacto limitado y relativamente corto en su duración en el campo de batalla. Con cierta rapidez — cada vez más_-, el enemigo se pone en disposición de equilibrar la balanza. Lo importante, lo duradero y, por ello, quizá lo determinante es el cambio, transformación o revolución en el modo de enfocar el uso de ese arma y la capacidad de mantenerse continuamente fresco para hacer adaptaciones sobre la marcha. Esto nos lleva a los moldes teóricos, a la doctrina y, con ellos, a los planes de instrucción y adiestramiento de mandos y tropa. Ahí es donde está la evolución y la adaptación. Y para ello no es tan importante hablar de «revoluciones militares» cuanto de una continua praxis de imaginación e ingenio, análisis histórico y flexibilidad.

Los papeles siempre se han ido tornando de un lado de la colina al otro lado, a veces en cuestión de poco tiempo, a lo largo de la propia batalla. Ante estos retos, continuos, exigentes hasta el final para un ejército, ¿qué ejército no ha buscado la mejor manera de adaptarse? Por todo ello, la RMA no parece si no un modo de encubrir lo que no es más que una pura evolución. Y la «transformación» parece, simplemente, la actitud que subyace en cualquier estructura militar, necesitada de adaptarse a los retos que debe acometer en cada momento. Nada nuevo, entonces, bajo el sol de Marte.

\subsection{Las coordenadas perpetuas de la guerra.}

La necesidad de defenderse es y será siempre una necesidad multiforme y, por ello, muy variada y variable. Es meridianamente claro que el ejército que no se adapte lo suficientemente rápido puede no tener posibilidades algunas de éxito, máxime cuando, como ocurre hoy día, todo se dirime en unas coordenadas de tiempo mucho menores que en otras épocas. Tres son las coordenadas clásicas, perpetuas diría, que se tienen en cuenta a la hora de examinar las opciones militares o la guerra ${ }^{69}$ :

- En primer lugar, deben examinarse, en el plano más estratégico, las coordenadas espacio/tiempo. Cuánto espacio tenemos que obtener (o podemos perder), si es el caso; y de qué tiempo contamos para ello, o para quebrar la voluntad de lucha del enemigo. No cabe duda que las democracias parlamentarias modernas, aun cuando parecen haber

69 Entre otros, pueden consultarse T. N. Dupuy, La comprensión de la Guerra, cit., y H. STRACHAN, Ejércitos europeos y conducción de la guerra, EME, 1985. 
conseguido erradicar la guerra de sus territorios, tienen siempre la presión del tiempo, que hace especialmente compleja su lucha.

- En segundo lugar, ya en un plano más operacional, está el criterio de la ofensiva/defensiva. Deberá examinarse cómo se va a plantear la acción, si como una reacción a hechos producidos o, por el contrario, adelantándose mediante la ofensiva. Y si ese juego se va a hacer en un plano estratégico o meramente táctico. Nuestra Constitución impide la guerra ofensiva, por lo que nuestra ofensiva solamente podría ser táctica u operacional, pero no estratégica o total, como hiciera Israel en la Guerra de los Seis Días ${ }^{70}$.

- En tercer lugar, ya en el terreno de la táctica, tendremos que valorar, junto con todo lo demás, el uso del fuego/maniobra, en el sentido más amplio de estos términos, muy relacionados con el anterior punto ${ }^{71}$.

Como puede apreciarse, se trata de tres constantes en la guerra, que son un sustrato en todas las acciones bélicas. No soy capaz de apreciar otras diferentes que éstas. De ahí que todos los nuevos inventos y formas, adaptaciones e instrumentos los tengamos que insertar dentro de estas tres coordenadas básicas. Nunca los medios tecnológicos deben perder de vista que se trata de medios, de sistemas para ayudar a la toma de decisiones. Una excesiva tecnificación — como denuncia GRAY que ocurre en los EE.UU. ${ }^{72}$ puede hacer perder la adecuada perspectiva para ganar la guerra en el terreno estratégico-político, además de en el puramente táctico, donde sí puede marcar, claramente, la diferencia.

Carl vON ClausEWITZ denominó, con enorme acierto, «niebla de la batalla» a esa confusión que se genera en la dirección y el mando de una batalla cuando se produce el choque de las tropas enfrentadas ${ }^{73}$. Utilizaba una realidad física —el humo grisáceo que producía la combustión de la rudimentaria pólvora negra de los mosquetes y de las baterías de artillería napoleónicas- para hablar de algo más profundo: la confusión en el conocimiento y la fricción que la realidad inesperada creaba sobre los pulcros planes preparados por los Estados Mayores de los ejércitos. Puede decirse que, en la era global, esa fricción nebulosa salta del campo de batalla - también ampliado en su tiempo y espacio- a todo el globo. Por eso también la guerra pierde frente y gana en profundidad, de tal manera que el principio artillero de los «fuegos profundos» se convierte, en cierto modo, en un paradigma global de hacer la guerra (como ha sido el caso de $A l$ Quaeda en el 11-S).

70 En cierto modo, la reforma de la Ley Orgánica de Defensa Nacional (LODNOM), que luego veremos, ha corregido nuestro ordenamiento, para evitar que se pueda participar en operaciones bélicas anticipatorias que rompan este criterio constitucional, por lo demás difuso.

71 Véase, al respecto, F. AlEJANDRE MARTínEz, «La tecno-guerra que... ¿viene?», en Ejército, núm. 722, abril 2001.

72 C. S. GRAY, Weapons don't make war: policy, strategy and military technology, Kansas University Press, 1993, in toto.

73 C. von Clausewitz, De la guerra, Labor, 2. ${ }^{a}$ ed., 1972, pág. 141. 
Pues bien, revolución o transformación no pueden ser ideas que nos empañen la necesidad de pensar y repensar, una y otra vez, en los riesgos, amenazas, inseguridades, siempre en el marco de esas coordenadas. Porque si perdemos de vista el examen de sus posibles efectos sobre esas bases sólidas, corremos el peligro de ir demasiado lejos en nuestra transformación o de llenarnos - no será nuestro caso- de costosos sistemas que, luego, no sabemos cómo integrar en una doctrina sólida de empleo. Y quedarán, como dijeran Patton de la línea Maginot y Budford de los sables, como insignes monumentos a la estupidez humana. Y seremos derrotados.

\section{La integración: combinación, conjunción, interoperabilidad y modularidad}

Aunque no podamos tratar sobre qué sea la revolución en los asuntos militares (RMA) y la transformación, estos modelos han alumbrado numerosos estudios que, en ese marco ideal quizá exagerado, aportan, no obstante, numerosas cuestiones de gran interés. Vamos a tratar de sacar en limpio algunas de ellas pues, pese a la valoración crítica que hago de su encuadre, la realidad es que, cuando se baja a las concreciones que la RMA y la transformación exigen, hay mucha materia aprovechable.

1) Combinación y conjunción. Las nuevas realidades estratégicas nos han llevado a formar parte de alianzas militares. En este contexto es preciso actuar combinadamente con fuerzas de otros países. Esto, como es evidente, tiene numerosas dificultades. La primera y principal es la barrera idiomática y, luego, las derivadas de los diferentes sistemas que operan en los ejércitos, así como de los celos en información y empleo de medios. Es evidente que también resulta complejo el equilibrio de mando, por no hablar de la doctrina de empleo y, por supuesto, la determinación de su uso. Pese a todo ello, las maniobras combinadas continuas entre países aliados, y en especial en las unidades de la UE y la OTAN, ponen de relieve cómo todo esto existe ya. $\mathrm{O}$, si no existe, se esfuerzan en crear.

Es evidente que los ejércitos siempre se han necesitado mutuamente. Desde que fueron surgiendo los tres clásicos (Tierra, Mar y Aire) se han ido estableciendo lazos comunes en su actuación. Muchas guerras han demostrado que todos ellos forman las Fuerzas Armadas y se necesitan totalmente. Estas lógicas afirmaciones no eximen de responsabilidad a las personas que los forman y que, por razones del todo humanas $-\mathrm{y}$ por ello naturales-, debaten continuamente sobre cómo se ven los retos que los acucian, pudiendo apreciar perfiles distintos y soluciones diversas. Y, por lo tanto, encontrando dificultades habituales de entendimiento y comunicación. Pero cada día se aprecia mejor la necesidad de colaborar, por cuanto la reducción y eficiencia en el uso de los medios militares evita la duplicación y favorece una mayor interoperabilidad.

De ahí que, a día de hoy, la conjunción de las tres fuerzas sea uno de los 
mayores retos de toda fuerza armada. Y no sólo entre los tres ejércitos del artículo 8 de la Constitución, sino también dentro de cada ejército, entre todas sus armas y medios, pues incluso esa conjunción debe alcanzar o verse alcanzada, algún día de éstos, por las Fuerzas y Cuerpos de Seguridad ${ }^{74}$. Si se abriese paso, entre nosotros, una clara idea de seguridad nacional, frente a la obsoleta visión de la defensa nacional, nos daríamos cuenta de que tanto los ejércitos - las FAS - como los cuerpos policiales y de seguridad — las FCS-, aun siendo distintos, cosa que no niego en modo alguno, deben jugar juntos en el complejo juego de la seguridad nacional ${ }^{75}$.

2) Otra idea aprovechable de todo este proceso de redefiniciones que estamos acometiendo es la de interoperabilidad, que aún es más concreta que las anteriores. Se trata de crear doctrinas, estructuras orgánicas y adquirir medios que sean compatibles para todos los ejércitos. Es, en el fondo, un requisito o una consecuencia de la conjunción e implica un cierto cambio de mentalidad, por cuanto supone renunciar a las políticas autónomas de material, así como la búsqueda de formas de entendimiento mucho más automáticas y sencillas entre las diversas fuerzas. A veces bastará con hacer las mediciones oportunas del material que se pretende embarcar para construir hangares en los que quepa, otras de buscar sistemas de armas compa-

74 En la actualidad, en el mundo entero, cada vez es más frecuente ver a militares haciendo funciones policiales y a policías que hacen o que colaboran en funciones propiamente militares. De un lado, y basta con ver la televisión, es frecuente ver unidades militares que colaboran en el ámbito interno para realizar labores de vigilancia especial, control de multitudes y de lugares sensibles, apoyo a la policía; y, por otro lado también es frecuente la participación de fuerzas policiales en misiones - militares hasta ahora- de pacificación o de intervención humanitaria. Irlanda del Norte, el plan vigi-pirate en Francia, en lugares sensibles de Nueva York, la protección de las vías del tren de alta velocidad en España, etc., han sido ejemplos de lo primero. Las operaciones de intervención humanitaria $-\mathrm{y}$, sobre todo, sus posteriores de estabilización social y política- en Bosnia, Kosovo y Timor Oriental son ejemplos de lo segundo. Pero hoy día los antiguos países del bloque soviético y algunos países iberoamericanos (sobre todo de Centroamérica, puesto que los países del Cono Sur ya cuentan con fuerzas de este tipo, como los Carabineros chilenos o la Gendarmería argentina) demandan unas policías muy especiales: polivalentes, disciplinadas y jerarquizadas, muy honestas, fuertes, flexibles, con capacidad para entrar a todo el territorio. La OTAN, pública y privadamente, ha propugnado el modelo de policía militarizada tipo gendármico (y especialmente el de la Guardia Civil española) como paradigma para esto. La gran asignatura pendiente (mejor solucionada en la Gendarmería nacional y en los Carabinieri italianos que en la Guardia Civil española) es su mejor imbricación con las Fuerzas Armadas [muchas de estas ideas también fueron apuntadas por M. JANOWITZ, El soldado profesional, cit.; también, G. JAR COUSELO, «¿Militares policías o policías militares?», en X Seminario Duque de Ahumada (El Estatuto de las Fuerzas y Cuerpos de Seguridad y la Guardia civil), Dirección General de la Guardia Civil y UNED, 1999, págs. 287 y ss.].

75 Más aún, esa combinación debe, además, integrarse más y mejor con el resto de servicios públicos uti universi: diplomacia, economía-industria-comercio, inteligencia, cooperación exterior, etc. La multidimensionalidad de los nuevos riesgos y amenazas exige una actuación integral —e íntegra- de esfuerzos. Esto es, en el fondo, lo que subyace bajo las siglas EBAO (Effect Based Approaches to Operations), que ha acogido la OTAN como una forma de evaluación y actuación en los escenarios de sus misiones, como señala el Panorama Estratégico de la Defensa 2006/2007 del Ministerio: se trata de evaluar qué necesita la fuerza -y debe llevar (medios militares, diplomáticos, policías, ingenieros, equipos médicos, etc.) - según los efectos que se estiman del fin que se busca. 
tibles con todas las exigencias militares de cada ejército, y otras, finalmente, en llegar a acuerdos para la adquisición de medios únicos para todos.

Entrando en un terreno concreto, España necesita actualmente un gran esfuerzo en interoperabilidad, empezando por la cúpula militar y los cuarteles generales. Aunque en los últimos años los avances han sido importantes, no son definitivos, si es que pueden serlo algún día, cosa que dudo. Parece preciso un total desprendimiento del territorio por parte de las unidades del ET, abandonando a radice el tradicional sistema divisional y territorial. Se necesitan medios interoperables con gran urgencia, pues una loca política de armamentos por ejércitos ha llevado a una absurda división entre los sistemas armamentísticos, con todo lo que ello supone de costes y complejidades en el mantenimiento y gestión, máxime en un ejército de reducidas dimensiones y bajo coste forzoso. Son tremendamente urgentes los aviones de transporte operacional (A 400), los carros sobre ruedas con adecuada capacidad, vehículos MRAPs ${ }^{76}$, helicópteros de combate con altas capacidades de supervivencia, sistemas de vigilancia y destrucción no tripula$\operatorname{dos}^{77}$ y otros muchos sistemas menores que, no obstante las mejoras de los últimos años, están aún necesitados de un enfoque más rápido para cubrir algunas necesidades esenciales ${ }^{78}$.

Por otro lado, las exigencias de formación de soldados y suboficiales se acrecientan, al tener que actuar en terrenos muy variados y variables, con injerencias de las autoridades civiles propias y necesidad de actuar con las autoridades locales o sus remedos, con paradigma cero-bajas y evitando ba-

76 Mine Resistant Ambush Protected: vehículos capaces de absorber el impacto de las minas y de soportar - y rechazar - ataques sorpresa con armas medias y lanzagranadas. Esto exige mayor blindaje que los vehículos ligeros tipo Hummer, Land Rover o similar, ventanillas con aperturas, muchas salidas, suelo antiminas, ballestas reforzadas, capacidad NBQ. Todo ello implica más peso, más volumen, lo que exige seis ruedas o ruedas traseras dobles, pero da mucha más seguridad que los vehículos ligeros y es mucho más móvil que los vehículos acorazados sobre orugas o 8 por 8 .

77 Los avatares del SIVA español — programa iniciado entre el Ministerio de Defensa y el INTA en 1993 (oficialmente algunos años más tarde) y que, a fecha de 2006, no ha sido capaz de elevar el vuelo, dicho sea en términos figurados- llevaron a las autoridades del Ministerio de Defensa a contratar cuatro aviones de reconocimiento no tripulados a IMIRafael, para dotar a nuestras fuerzas en Afganistán. En el Día de las FAS de 2007 se mostraron, no obstante, las brillantes capacidades del SIVA, desfilando posados sobre sus camiones de transporte. Dejo que el lector se haga todas las preguntas que quiera sobre el coste, eficacia, eficiencia y operatividad de nuestro avión, de casi quince años de desarrollo (Avión Revue, núm. 303, septiembre 2007, págs. 18 a 22).

78 Como vamos con algunos años de retraso, en los últimos años hemos aprobado la adquisición de medios acorazados pesados que no podemos desplegar, retrasando, con ello, la adquisición y/o mejora de sistemas más versátiles (tipo MRAPs). También hemos sustituido todos nuestros vehículos más ligeros por otros, a la moda de EE.UU., entre los años 19932003, que precisamente están siendo cambiados por otros sistemas más protegidos, tipo MRAP, Stryker o equivalentes (dotándolos, además, de medios de protección extraordinarios). Dado lo lento de nuestros procesos de constatación de la necesidad, evaluación del producto y contratación administrativa..., cuando nos decidamos por ellos, el resto de países habrá optado por otros sistemas nuevos. Todo ello se puede seguir, puntualmente, en www.elalijar.blogspot.com, www.larharkadeaspizua.blogspot.com, y www.eltiradorsolitario. blogspot.com. 
jas civiles a toda costa. En fin, un panorama complejo que exige unos niveles de formación.

3) Modularidad. Desde Napoleón, principalmente, se fue abriendo paso la creación de grandes unidades militares, las divisiones, que agrupaban una gran cantidad de medios bélicos en unidades autónomas o cuasi autónomas. Había sido una respuesta iniciada por el corso a raíz de su triunfo sobre los microejércitos profesionales, de medios no dispendiables, propios del siglo XVIII.

La autarquía militar — preconizada desde el siglo XIX hasta la década de los años ochenta del xx- sostenía que las FAS debían ser capaces, con toda lógica, de mantenerse autónomamente sobre el terreno durante largos periodos. Para ello era precisa la sustitución de las autoridades del lugar por las propias y la integración de toda la economía en el esfuerzo bélico. Esto era posible con ejércitos grandes, normalmente de reemplazo, con medios pesados y con unas doctrinas que hacían mucho hincapié en los «asuntos civiles», pero llevados por militares. La mayor dificultad de todo ello era la lentitud en el despliegue y la enorme duración del esfuerzo. La guerra fría fue su clímax, con la aparición de completas y gruesas divisiones, sobre todo acorazadas y/o mecanizadas, que tenían, dentro de sí, una suerte de ejército en miniatura. Los nuevos tiempos han ido exigiendo el adelgazamiento de estas unidades y, con ello, de los medios con que cuentan. Durante un tiempo se ha consolidado la unidad tipo brigada, normalmente con un uso específico y determinado de antemano (paracaidista, montaña, acorazada, caballería, etc.).

Como se ha visto en Irak o Afganistán, sí parece que es deseable, al menos en mayor medida, una cierta vuelta a esas capacidades. Por eso se habla, como un remedo de esa autarquía histórica (hoy imposible), de sostenibilidad. Y las organizaciones internacionales tratan, sin demasiado éxito, de esforzarse por crear unidades que combinen la rapidez en el despliegue, la fortaleza en su actuación, un nivel adecuado de protección y una capacidad de mantenerse sobre el terreno con cierta duración. Si esto se combina con el hecho de que esas fuerzas tienen que acometer, frecuentemente, misiones muy variadas (apoyo a la población civil, ayuda humanitaria, reconstrucción estatal, educación, diplomacia, contrainsurgencia y puro combate), puede colegirse que las exigencias son mucho mayores que las capacidades.

Pues bien, la modularidad sería un sistema según el cual una brigada, o unidad similar, siendo una unidad altamente autónoma, sea capaz de operar mediante módulos intercambiables, con medios prestados o utilizando los que se consideren más adecuados para el tipo de misión que se le encomiende. Esa característica exige, también, un esfuerzo de combinación con el resto de recursos antes citados: inteligencia, seguridad, cooperación civil, etc. ${ }^{79}$.

79 El sistema, en cierto modo, deriva de los kampfgruppen alemanes, exigidos por las difíciles circunstancias del teatro de operaciones de final de la segunda guerra mundial $\mathrm{y}$, también, ha sido muy experimentado mediante el sistema de rotación de regimientos y batallones de infantería británicos, por las unidades estructurales ubicadas en diversos lugares, con cometidos distintos (Rhin, Ulster, Chipre, Noruega, Belice). 
Esto permite que todas las unidades estén entrenadas para diversos usos y puedan modular su actuación con los medios disponibles y adaptarse, fácilmente, a los demás medios.

III. LOS NUEVOS RETOS O AMENAZAS A LA SEGURIDAD «NACIONAL»: ASPECTOS JURÍDICOS

1. Defensa y seguridad nacional: la Ley Orgánica de la Defensa Nacional de 2006

1.1. El panorama de las misiones exteriores de las FAS y su marco constitucional.

El marco desde el que nos aproximamos al estudio de las Fuerzas Armadas desde la transición es, una vez rota la idea de la «guerra» como factor aglutinante, el de la «defensa» ${ }^{80}$. Nuestra Constitución no acepta, además, la guerra ofensiva por dos motivos. El primero, de carácter más interpretativo, al promover las relaciones «pacíficas entre los pueblos». El segundo, con pleno valor jurídico, al aceptar el Tratado de la ONU, cuyos artículos 2.4 y, sobre todo, 51 prohíben expresamente el uso de la fuerza en las relaciones internacionales y la supeditan a la legítima defensa, en condiciones muy precisas y exigentes ${ }^{81}$. Nuestro Ministerio es una estructura encargada de la organización de la defensa y nuestros ejércitos se han organizado bajo este paradigma.

El artículo 8 de la Constitución, como es conocido, señala que la misión de los tres ejércitos es "garantizar la soberanía e independencia de España, defender su integridad territorial y el ordenamiento constitucional». Dado que los tratados internacionales defensivos, como el Tratado de la OTAN, son recibidos por nuestro ordenamiento, los fines militares que esos tratados fijen se convierten en parte de nuestro ordenamiento jurídico (capítulo III del Título III). En el ejercicio de la política exterior, el gobierno puede concretar, además, esos fines con las misiones concretas que tales instituciones establezcan, como es, especialmente, el caso de la OTAN, la UE y la ONU. El artículo $97 \mathrm{CE}$ no deja duda alguna al respecto.

No deja de ser, no obstante, un panorama bastante parco, desde el punto de vista jurídico. Las Reales Ordenanzas para las Fuerzas Armadas, en su artículo 9, abrieron la posibilidad de las acciones humanitarias, complementarias de las antes citadas. Pero, luego, la Ley Orgánica de la Defensa Nacional (Ley 6/1980, reformada por la Ley 1/1984) volvió a adoptar casi el

80 Así, el Ministerio pasó de llamarse Ministerio de la Guerra y del Ejército, luego, a denominarse Ministerio de Defensa durante la transición (se acaban de celebrar los treinta años).

81 Fruto de lo cual han contribuido a su uso fuera del marco de esa carta: R. BERMEJO, El marco jurídico internacional en materia de uso de la fuerza: ambigüedades y límites, Civitas, 1993. 
tenor literal del artículo 8 de la Constitución. En cualquier caso, en todas esas normas se aprecia una visión muy clásica de la misión de las FAS, centrada, al fin y a la postre, en ejercicio de las funciones bélicas en el marco de unas misiones muy tradicionales, siempre de carácter defensivo.

Pero, pese a la vigencia de este marco normativo, nuestras Fuerzas Armadas no han actuado, estrictamente hablando, en ninguna guerra defensiva $e x$ artículo 8.1 Constitución. Cierto es que, en puridad, la propia declaración de guerra y «estado de guerra» son, hoy, conceptos vacíos, no tanto de contenido cuanto de existencia ${ }^{82}$. No obstante esa afirmación, las Fuerzas Armadas españolas, en diversas formas y grados, sí han combatido, en el sentido más estricto del término: Bosnia 1995, Kosovo 1999, Irak 2003, y actualmente en Afganistán. Todos ellos han sido lugares de guerra y comba$\mathrm{te}^{83}$. Ha habido, además, acciones bélicas que, no obstante, no parecen haber exigido combate: Perejil 2004, el Líbano 2006, principalmente.

Pero, especialmente, se ha hecho uso creciente de las FAS para numerosas misiones de otro tipo: ayuda humanitaria, interposición de fuerzas, vigilancia de tratados, etc. Así, Irak 1990, Bosnia 1991-1995 (hasta el mandato OTAN), Kosovo tras 1999, Haití, Darfour, Huracán Mitch en Centro-américa, etc. También se ha ido a otras tantas operaciones «menores» de observadores bajo mandato ONU, OTAN o OCSE, aportación de medios aéreos, ayuda humanitaria en medios militares, auxilio civil, muchas de ellas con poco eco mediático. Y, por supuesto, las grandes desconocidas: las misiones de los buques de la Armada en el cierre y vigilancia de sectores y tráfico marítimo en el marco de la «Guerra contra el terror» $\mathrm{u}$ otras operaciones internacionales. Y, también, numerosas operaciones del Ejército del Aire en el exterior y, a diario, en la protección de nuestro espacio aéreo. Todas ellas difícilmente encajarían bajo el artículo 8 , en una lectura estricta del mismo. Su marco jurídico es, más bien, el que establece el artículo 97 en relación con la Carta de Naciones Unidas y sus resoluciones consecuentes sobre esos conflictos, a veces mandando a la OTAN (salvo en Kosovo, donde esta organización actuó por su cuenta y riesgo).

Además, en los últimos tiempos, los tres ejércitos han colaborado en funciones de apoyo a las autoridades civiles en materia de seguridad: vigilancia de edificios, sistemas, plantas energéticas, centrales eléctricas, etc.; vigilancia del mar territorial y fronteras y colaboración frente a las mafias de tráfico ilegal de personas, droga, etc. De siempre, además, ha existido una colaboración con medios y personal militar a las autoridades civiles en

82 J. García FERNÁNDEZ, «Guerra y Derecho constitucional. La formalización del inicio de la guerra mediante declaración en Derecho internacional y en Derecho interno», en Estudios de teoría del Estado y Derecho constitucional en honor de Pablo Lucas Verdú (dirs. R. Morodo y P. DE VEGA), tomo II, UCM y UAM, 2001, págs. 1037 y ss.

83 Dejando de lado la cuestión militar, puede verse su proceso jurídico en J. GARCía FERNÁNDEZ, «El Parlamento y la guerra. La posición de las Cortes Generales ante las misiones militares en el exterior», en Asamblea. Revista Parlamentaria de la Asamblea de Madrid, núm. 8, junio 2003, págs. 117-161. 
desastres naturales (inundaciones de Bilbao, hundimiento del petrolero Prestige, incendios forestales, colapsos por nevadas, etc.).

¿Pueden acogerse estas operaciones bajo el artículo 8 CE? Bajo una lectura generosa de la obligación de defender la «integridad territorial» podría encajarse la lucha contra incendios e inundaciones, como de cualquier riesgo para la población española y el espacio geográfico que ocupa. Nuestra soberanía se defiende frente a amenazas terroristas y delictivas en muchas de las misiones expuestas (planes de vigilancia de infraestructuras y fronteras, lucha contra redes delictivas en otros lugares del planeta). El resto de misiones entrarían, con un criterio amplio y por remisión a otros lugares de la Constitución, bajo el inciso «defender... el ordenamiento constitucional». El problema, no cabe duda, es cuando se trata de misiones claramente bélicas -en ocasiones verdaderamente ofensivas, como Kosovo en 1999 o Irak en 2003-, cuando o bien carecen - por un motivo u otro, que ahora no es el caso- de un mandato expreso de Naciones Unidas, o bien se apoyan en normas endebles o con una legitimidad muy discutida, como ocurrió con Irak en 2003.

\subsection{La «Revisión Estratégica de la Defensa».}

Nuestra doctrina militar ha mantenido un catálogo de operaciones militares en las que se podía desglosar el uso de la fuerza: operaciones bélicas, contra insurgencia, apoyo a la población civil, interposición humanitaria, refuerzo de la paz, etc. ${ }^{84}$. Pero se trataba de una previsión militar que tenía que ver más con los medios y las formas que con el tipo de operaciones al que se les dirigiese por parte del poder político. Participamos, no obstante, en muchas de ellas por la vía de la previsión del artículo $97 \mathrm{CE}$, que deja al gobierno la dirección de la política exterior y militar y la organización de las FAS.

Un giro sobre esta situación tan conservadora en el plano de la regulación jurídica se aprecia no en una norma, sino en la Revisión ${ }^{85}$ Estratégica de la Defensa del año 2003 (RED), documento sin valor jurídico. Se trata de un documento programático en el que se marcan las ideas, criterios o directrices en los que debería basarse nuestra defensa en los años venideros, resultante del proceso de marcación de la defensa que inició la Directiva de la Defensa Nacional (DDN) 1/2000 86 . Ahí, tras un capítulo II dedicado al análisis de los nuevos riesgos que amenazan nuestra seguridad, el capítulo III se-

84 Catalogación muy precisa que puede verse en W. T. JOHNSEN, Redefining land power in the 21th centruy, ISSS, London, 1998. También, perfectamente, en la DO1-001, Doctrina para el empleo de la fuerza terrestre del Ejército de Tierra, en todas sus ediciones desde 1993.

85 Equívocamente llamado así, por cuanto nunca antes había existido una Visión previa inicial que ahora se revise. El nombre debiera haber sido «Visión Estratégica de la Defensa». El anterior documento similar —o que pretendió serlo, más bien-, es decir, el Libro blanco de la Defensa 1996, no fue otra cosa que una mera recopilación, con fotos y dibujos, de la realidad de las FAS, sin casi ninguna utilidad teórica o doctrinal.

${ }^{86}$ Luego sustituida por la DDN 1/2004, que cambia su visión general, acomodándola a lo que, luego, aparecería en la LODN. 
ñala de una manera algo difusa que las misiones de las FAS, además de las tradicionales misiones defensivas de la Nación, son: 1) Proyección de seguridad en el marco de organizaciones regionales de seguridad (OTAN, UE), bajo las líneas de disuasión, cooperación, prevención, estabilización y capacidad de respuesta a las agresiones lejanas; y 2) Preservación de la seguridad y el bienestar de los ciudadanos, mediante actuaciones de apoyo a las autoridades civiles en catástrofes, atentados, control de fronteras y seguridad general. Además, a continuación, en varios lugares se presupone la necesidad de que nuestras FAS actúen en misiones de combate bajo mandato ONU, dirección OTAN-UE y en el marco de esa proyección y creación de un espacio de seguridad común. Puede decirse, por lo tanto, que adopta una visión muy pragmática y amplia de la realidad, dando muchas posibilidades de juego a las FAS. Aunque a todo ello, en puridad, le deberían acompañar las leyes, para darle una adecuada vestidura jurídica.

\subsection{Ley Orgánica 5/2005, de la Defensa Nacional.}

A) Una reforma legislativa necesaria, pero desaprovechada.

Por fin, en 2005 se aprobó la necesaria reforma de la LODN de 19801984, que, con veinticinco años de vigencia, había quedado obsoleta. En esta Ley se encara la cuestión de que nuestras FAS, como ha quedado descrito, han superado ampliamente el marco de funciones y misiones que contemplan la Constitución y la anterior LODN.

Esta Ley contiene 31 artículos, algunos de los cuales iremos estudiando a continuación al socaire de los temas que tratan. Los grandes temas que trata son los siguientes, dicho sea de manera muy breve: 1) Funciones y atribuciones del Presidente, el Ministro de Defensa, Consejo de Ministros y Cortes Generales en relación a la política de defensa y las FAS (arts. 2 al 6). 2) Reorganización del aparato organizativo gubernativo de defensa nacional (arts. 7 y 8). 3) Reorganización de la estructura superior de la defensa militar (arts. 9 y 12). 4) Fines y misiones de las FAS (arts. 15 y 16). 5) Estatuto jurídico de las operaciones militares españolas en el extranjero y de su legitimidad y legalidad (arts. 17 y 18) ${ }^{87}$. 6) Organización básica de los ejércitos y las FAS (arts. 10, 11, 13 y 14, la jurisdicción militar). 7) Remisión legislativa a las reglas esenciales y disciplinarias de los miembros de las FAS (arts. 20 y 21). 8) Contribución del resto de poderes del Estado a la defensa nacional (arts. 22 y 28 a 31). 9) Guardia Civil (arts. 23, 24 y 25) y Cuerpo Nacional de Policía (art. 27). Y 10) Centro Nacional de Inteligencia (art. 26).

Pese a la grave apariencia de estos epígrafes y haciendo un juicio algo simple y, por ello, quizá injusto, debe decirse que el contenido es pobrísimo.

87 Creemos que se trata de un punto de indudable interés y acierto pero que, por exigir un estudio mucho más concienzudo del que aquí podría hacerse, es preciso dedicarle otros trabajos. 
Dejando de lado todos los aspectos relativos a las misiones y funciones, que veremos a continuación (punto 4), y la legitimidad en el uso de la fuerza (punto 5), que nos merece un juicio positivo, el resto es pura apariencia. Los aspectos 1, 2, 3 y 6 reorganizan algo, que no mucho, la estructura de la defensa, que valoraremos luego. Pero a partir del epígrafe 7 y hasta el final es tanta la grandilocuencia de sus nombres como el vacío de contenido. Apenas puede enjuiciarse, en un sentido u otro, porque ha dejado todo sin contenido alguno. Algunas veces porque es sólo un mandato legislativo (punto 7), otras porque no se ha atrevido a decir nada que no se supiera (puntos 8 a 10) $)^{88}$.

Nos parece que, como veremos, lo que lastra esta visión tan plana y tan pobre de la defensa nacional es que ésta no existe más. Pero no puede decirse «El Rey ha muerto, viva el Rey», por cuanto nada ha sustituido ese decrépito concepto. Es decir, en tanto no se acoja y defina la «seguridad nacional» y no se reforme en serio la organización directiva de la defensa nacional, sus funciones y misiones... todo lo demás será predicar en el vacío de un desierto. Eso es lo que ha ocurrido con la Ley. Por mucho esfuerzo que sus redactores quisieran poner - que parece haberse agotado en la redacción de los importantes, aunque confusos, arts. 17 y 19-, no era posible resolver nada más sin esa «transformación» de mentes que es precisa.

B) En particular, el fin, misiones y funciones de las FAS.

El artículo 15 de la LODN recoge las misiones. En su inciso $1 .^{\circ}$ señala las clásicas: las del artículo $8 \mathrm{CE}$. En el inciso $2 .^{\circ}$ recoge la cooperación con aliados en la seguridad y defensa, mantenimiento de la paz, la estabilidad y la ayuda humanitaria. Después, el inciso $3 .^{\circ}$ contempla la posibilidad de colaboración con las autoridades civiles, tal y como decía la RED. Finalmente, el inciso $4{ }^{\circ}$ nos habla de "misiones de evacuación de los residentes españoles en el extranjero» en determinadas circunstancias.

El artículo 16 LODN hace un elenco de seis tipos de operaciones a modo ejemplificativo, que no son un numerus clausus, al señalar, literalmente, que «las operaciones pueden consistir en...»: a) Vigilancia y control del espacio aéreo y marítimo. b) Colaboración en operaciones de paz y estabilización internacional, reconstrucción nacional, etc. c) Apoyo a las FCS en la lucha antiterrorista, búsqueda y salvamento. d) Respuesta militar a ataques terroristas mediante aeronaves. e) Colaboración con las autoridades civiles en catástrofes. f) Participación con otros organismos y aliados en operaciones de preservación de la seguridad de nacionales de esos países en otros lugares en conflicto.

88 Sin ser, en modo alguno, un dato esencial, resulta significativo que los artículos 20 al 31 ocupen poco más de una página del $B O E$, en tanto que el artículo 8 (Consejo de Defensa Nacional) ocupa casi media página, y del 16 al 19 ocupen casi una página entera. La lectura del contenido de los artículos 20 al 31 creo que corrobora las afirmaciones vertidas. 
Era muy necesario, como ya se ha insistido, realizar una seria actualización de las misiones y funciones de las FAS. Pero parece que estos dos artículos realizan una catalogación que, cuanto menos, puede calificarse de confusa $^{89}$. Y esto sin entrar en la cuestión de cuáles son el fin, las funciones y las misiones, con sus ejemplos, que corresponden a las FAS, que también estaría necesitado de un debate mucho más profundo. Éstas son las objeciones de claridad que lastran el texto:

- El artículo $15.4 .^{\circ}$ expone, entre las misiones, lo que resulta, claramente, un tipo de operación («evacuación de españoles...»). Que, además, luego vuelve a recoger en la letra f) del artículo 16.

- En el artículo 16, las letras c), d) y e) son meros ejemplos de lo que casi estaba expresamente apuntado en el artículo $15.3 .^{\circ}$, por lo que no aportan demasiado

- En cuanto al artículo 16, letra a) (operaciones de vigilancia aérea y marítima), no es sino una de las funciones derivadas del $15.1 .^{\circ}$ (defensa de la integridad territorial).

- Finalmente, el artículo 16, letra b) (colaboración en operaciones con países aliados), es otro mero ejemplo del 15.2..$^{\circ}$ (cooperación con los aliados en el marco de los tratados, etc.).

Es decir, nos encontramos con un juego de redundancias mutuas, sin demasiado acierto, además. Si ha optado por hacer un elenco de misiones o actuaciones a modo de sugerencias, como ha hecho el del artículo 16, bien podría haber sido mucho más amplio. En ese caso no hubiese sido preciso incluirlas, previamente, entre las misiones generales del artículo 15, como ha ocurrido. De tal manera que ese artículo 15 se hubiese limitado a establecer un marco jurídico general, no un conjunto de ideas con ejemplos. Sea como fuere, no se acierta a comprender, en cualquier caso, por qué el 15.4. ${ }^{\circ}$, que define, claramente, un tipo de operación, no una misión general, no la dejó para el artículo 16. Máxime cuando, además, ese tipo de misión ya encaja perfectamente dentro del $15.1 .^{\circ} \mathrm{y}$, sobre todo, en el 2. ${ }^{\circ}$.

La cuestión que subyace es que nunca ha habido un debate serio sobre fin, funciones y misiones de las FAS, salvo en los documentos militares doctrinales, donde sí está claro. El artículo $8 \mathrm{CE}$ trata sobre el fin, no las misiones; el artículo 15 nos está hablando de funciones. Y el artículo 16 cataloga misiones y tipos de operaciones, que son concreciones específicas del fin y las funciones. Ahí empieza el problema.

89 Así, también, F. J. NAVARro SANChís, «Diez puntos de reflexión sobre la LODN», en Revista Electrónica Jurídica Militar, núm. 15, año 3, enero 2006. 


\section{La modernización necesaria}

\section{1. ¿Defensa o seguridad nacional?}

A) La ausencia de una visión clara en la LODN.

En todo este marco expuesto: ¿Hasta cuándo resulta útil continuar hablando de defensa en un panorama en que no nos tenemos que defender - aunque podamos tener que hacerlo en algún momento- de nadie, pero en el que sí existe una suerte de defensa difusa de una serie de valores? ¿Cómo podemos defender esos valores de una manera que, como se ha visto en tantos lugares como los descritos arriba, no actuamos de un modo «militarmente» tradicional? ¿Por qué no se han activado nunca, como consecuencia de todo lo anterior, nuestros sistemas de dirección militar defensiva en esas situaciones?

No cabe duda que todas estas preguntas generan, además, otras muchas cuestiones: ¿Cuándo nuestros ejércitos han actuado en conflictos clásicos? Pues resulta que la historia más reciente nos enseña que las guerras y crisis bélicas en las que hemos actuado en los dos últimos siglos están llenas de ejemplos de lo que bien podríamos considerar «nuevas guerras ${ }^{90}$. Otra pregunta, y no menor, es si acaso no activamos nuestros sistemas precisamente porque lo hemos evitado al constituirnos como una parte de sistemas colectivos de defensa que, precisamente, buscan salidas no bélicas o, incluso, realizan acciones pre-bélicas o, en mayor medida, post-bélicas. Es decir, porque buscamos crear un entorno de seguridad que evite las amenazas defensivas en el sentido más militar del término.

Con todo, creo que las normas que hemos previsto para todas estas situaciones, siendo necesarias — ayer más que hoy, parece-, no han necesitado ser utilizadas. Y, así, la Ley Orgánica 4/1981, de 1 de junio, de declaración de los estados de emergencia, excepción y sitio, cuya última situación - el sitio- era el marco más apropiado para adoptar las medidas oportunas en caso de que hubiese un "estado de guerra». Pues ese estado de guerra, pese a aparecer en diversos artículos de las leyes penales y procesales militares y en las Reales Ordenanzas, así como en otros lugares, inclusive la propia Constitución, carece de un marco jurídico definitorio ni de desarrollo. De producirse, hubiese sido una mera situación fáctica, pero carecía de un régimen jurídico desarrollado. Lo más aceptable sería declarar el «estado de sitio» total o parcial en caso de crisis bélica que cumpla los supuestos

90 Marruecos, Sahara, Ifni, Cuba, Filipinas, etc. Conflictos bastante asimétricos, acciones contrainsurgencia, guerra de guerrillas, luchas con un alto componente político y religioso. Así, la propia guerra civil está siendo examinada por la RAND Corp. para estudiar fórmulas y soluciones para el avispero irakí, en el entendimiento de que la situación que allí se produce guarda enormes similitudes con nuestro conflicto fratricida (R. Aquilla y D. RoNFELDT, "The real analogy for Iraq", en www.rand.org; documento publicado en United Press International el 24 de agosto de 2007). 
de ese estado de cosas; de otra manera se dejaría al gobierno que implementase una situación a su albur.

La LODN de 1980/84 recogía con gran detalle y precisa dicción determinadas situaciones y organismos encargados del planeamiento y dirección defensivos. Si bien sucesivas normas administrativas habían ido replanteando la estructura orgánica de las FAS y, en concreto, la estructura de mando (sobre todo el Real Decreto 1250/1997, de estructura de mando operativo de las FAS). Lo previsto en la LODN se quedó, así, como una estructura un tanto estéril. Además, la plena incorporación a la estructura militar de la OTAN y la presencia de España en otras instituciones internacionales de defensa y seguridad traspasaron gran parte de la capacidad decisoria de activación y de dirección y control de las operaciones militares a organismos derivados de esas instituciones ${ }^{91}$.

En fin, la JDN y el resto de estructuras derivadas se quedaron como órganos de planeamiento general y de carácter muy excepcional. Y para las situaciones de crisis con algún componente de seguridad, los sucesivos presidentes del gobierno adoptaron otras fórmulas, en el marco de las normas administrativas sobre organización del gobierno y la Administración. Esto, aparte de la búsqueda de gabinetes formados por un exclusivo círculo de confianza, siendo preciso en ocasiones, supone, en el fondo, el fracaso de las normas que regulaban la cuestión. Así, en todas las situaciones de crisis se han creado gabinetes de crisis formados por los ministros que el presidente consideraba idóneos en cada caso y los «invitados» adecuados. Así ocurrió en Irak 1991, en Kosovo 1999, en Perejil 2002 y en Irak 2003, y en otras ocasiones menos relacionadas con crisis bélicas en el sentido más pleno del término, o incluso durante crisis de seguridad (rupturas de treguas de ETA, 11-M, crisis internacionales de seguridad).

Así las cosas, el elemento que se rastrea en todas estas situaciones es que, en el fondo, no se trataba de crisis defensivas, sino de amenazas a la seguridad. Efectivamente, en estos casos no estaban, generalmente, amenazados nuestro territorio, soberanía, pueblo y orden constitucional. Al menos, en este último caso, en un grado importante y decisivo. Pero es innegable que sí existían amenazas a la seguridad nacional y, como consecuencia ex post facto, a todos estos valores previstos en el artículo 8 de la Constitución. Hoy día, la defensa es, precisamente, la defensa de la seguridad nacional. Porque es la seguridad nacional la que hoy día está amenazada y en una situación de riesgo, por parte tanto de los nuevos guerreros como de las «nuevas guerras», aquí o en derredor. De hecho, uno de los problemas que tiene

91 En la Ley 17/1999, de Personal Militar de las FAS, se cambiaron los grados militares en la escala de generales para introducir al general de cuatro estrellas (teniente general) y de cinco (capitán general), en orden a que el Rey pudiese ostentar ese máximo grado, como corresponde. Pero el efecto era que el Rey, aunque tenga el mando simbólico, eminente, pero no efectivo, no tuviese por encima al SACEUR OTAN, un general norteamericano de cuatro estrellas, así como a los mariscales británicos o a cualquier otro mando de cuatro estrellas. Es simbólico, pero necesario (J. C. ALLI TURRILlas, «La potestad regia de mando sobre las Fuerzas Armadas», cit., págs. 593 y 594). 
hoy día la denominada «defensa nacional» y, con ella, las Fuerzas Armadas es la definición de su papel, de su misión y función. Pues el problema actual es de un profundo solape entre ejércitos, militares, y cuerpos de seguridad y policías. En definitiva, el problema es la defensa de la seguridad. Es así, pues, que seguridad nacional y seguridad pública (e incluso ciudadana) se compenetran, se necesitan, se exigen mutuamente, como bien ha visto la OTAN hace tiempo ${ }^{92}$. Nuestras FAS recorren medio mundo como auténticos policías internacionales en ese tipo de guerras. Pues bien, la defensa era medible en términos de disuasión y de paz, de ausencia de amenazas y de seguridad. Pero la seguridad - que es el concepto que acoge todo esto- es mucho más compleja. La defensa servía para evitar la guerra y ésta finalizaba con la victoria, clara, contundente. Pero la seguridad no llega a esa victoria, puesto que se tiene que limitar a evitar daños mayores o a congelar los efectos de la inseguridad. Así pues, ¿es posible continuar pensando en términos de «defensa nacional»? Y si es posible, ¿es realmente útil hacerlo y mantener sus estructuras?

B) Falta de integración de estructuras en ese concepto amplio de seguridad.

Así las cosas, llama la atención que la vigente LODN haya optado por una visión de "perfil bajo» a la hora de enfrentarse con esta nueva situación. Se continúa hablando de defensa y, derivado de esta idea, se establece el «Consejo de Defensa Nacional» como máximo órgano «colegiado, coordinador y consultivo del Presidente del gobierno» (art. 8.1), si bien cabe constituir, sobre su base, un más ágil Consejo ejecutivo. Luego, en cuanto a la integración de esfuerzos entre FAS, FCS y CNI, nos encontramos con que apenas se apunta nada que resulte interesante desde la perspectiva dibujada en páginas anteriores sobre integración, conjunción - previsto en el art. 10 para las FAS - y capacidades multidimensionales. De hecho, como ya se señaló, los puntos 8 a $10 \mathrm{LODN}$, descritos en el epígrafe 2.3.A), son normas sin contenido alguno.

Pues bien, ésta es la gran oportunidad perdida una vez más por una ley. Es cierto que no podemos pretender que la ley sea todo; más aún, las cosas no funcionan porque aparezcan contempladas en una ley -a veces es justo al contrario-, sino porque se hagan bien o mal. La ley no transforma la realidad, simplemente la viste para aparecer en público. Por eso nos parece que esta Ley debería haberse llamado, sin paliativos, Ley Orgánica de Seguridad Nacional (es decir, LOSN). Asimismo, el «Consejo de Defensa Na-

92 C. Donelly, «Replantear la seguridad», en Revista de la OTAN, invierno 2000-2001, págs. 32 y ss. Vayamos un poco más lejos. Antes señalaba que las guerras actuales son guerras post-heroicas porque carecen de un fin claro, de una terminación exacta y se empantanan en campañas no decisivas. Estas nuevas guerras tienen cierta tendencia a ser farragosas, largas, tediosas, difíciles de medir y de saber dónde acaban, ni siquiera cuándo empiezan (J. JoRdán y J. L. CALvo, El nuevo rostro de la guerra, cit., págs. 137 y ss.). 
cional» debería llamarse, sin eufemismos conservadores, «Consejo de Seguridad Nacional». Y en él deberían entrar a formar parte el Secretario de Estado de Seguridad y el Director General de GC y Policía. Sus reuniones, además de periódicas, deberían ser las únicas previstas en casos de emergencias para la seguridad, evitando, así, que el órgano ejecutivo quede estéril ante reuniones informales ad hoc que pueda crear el Presidente. Sin perjuicio de que, en el ámbito de su confianza, pueda reunirse previa o posteriormente con quien considere oportuno para recabar consejo y adoptar las decisiones políticas finales que sólo a él le corresponden.

Sería preciso que el Estado Mayor de la Defensa y el EMACON estuviesen, en esas ocasiones, en un grado de disponibilidad preconfigurado en la propia $L O S N$, como instituciones de apoyo en el planeamiento, coordinación y dirección de las operaciones más militares de entre las operaciones de seguridad nacional. Y todo ello debiera estar mejor previsto y concretado en esa norma.

Pero, dentro de ese panorama, sería más inteligible la progresiva modernización de las estructuras orgánicas y operativas de las FAS ${ }^{93}$. Y no solamente eso, por cuanto ese marco serviría para llegar al siempre pospuesto decreto de funciones militares de la Guardia Civil, que, más allá del problema concreto de éstas, debería encarar su imbricación puntual en la estructura de las FAS. También del servicio que las FAS pueden hacer en materia de apoyo a la Guardia Civil - y del propio CNP, en menor medida- en materia de seguridad nacional. Por otro lado, también sería útil para una verdadera integración de esfuerzos entre los servicios de investigación de las FCS, el CNI y el recientemente creado Centro de Inteligencia de las FAS (CIFAS). Y, en el terreno más colateral, marcaría más claramente el papel de las UME dentro del panorama general de labores auxiliares de FAS y FCS en la protección civil. Aspecto que resulta importante engrasar si se quiere contar, luego, con los sistemas de protección civil en situaciones de riesgo a la seguridad nacional.

\subsection{Reformas estrictamente militares.}

A) Reforma de estructuras.

Durante los últimos años, una vez más, se ha producido una profunda reestructuración de las FAS mediante el Real Decreto 787/2007, de 15 de junio, por el que se regula la estructura operativa de las Fuerzas Armadas; el Real Decreto 416/2006, de 11 de abril, por el que se establece la organización y el despliegue de la Fuerza del Ejército de Tierra, de la Armada y del Ejército del Aire; y el Real Decreto 912/2002, de 6 de septiembre, por el que se desarrolla la estructura básica de los ejércitos.

93 Reales Decretos 912/2002, 416/2006 y 787/2007, de estructura general de las FAS, reestructuración de los ejércitos y dirección operativa de las FAS, respectivamente. 
- Empezando por el Reglamento de 2002, éste partía de la base de que el sistema de estructura tradicional, muy pegado al territorio y de tipo divisional, resultaba ya obsoleto. Algo se había reformado durante los cambios de los años 92-94, pero todavía no estaba del todo afinado. Por ello, manteniendo la clásica estructura de los años 60-70 en Fuerza, Apoyo a la Fuerza y Cuartel General, se marca una racionalización basada en criterios funcionales, frente a la organización de tipo territorial. De tal manera que se ponen las bases para que aparezcan los mandos aéreos de combate y transporte, la flota de proyección y de defensa y, en tierra, las fuerzas de maniobra y las de defensa de área.

- La reforma del año 2006 es una actualización del anterior Plan Norte (1994) y pone el acento en la creación de unidades más pequeñas, tipo brigada, un redespliegue territorial y una aligeración de estructuras operativas y de apoyo a la fuerza combatiente en todos los ejércitos. Realmente, bajo esa necesaria simplificación, modularidad y capacidad de proyección, también se encubre el hecho cierto de que es imposible mantener grandes unidades operativas por insuficiencia de efectivos. En el caso de la Armada se apuesta por la proyección de la flota. El Ejército del Aire se centra en el control y la operatividad conjunta de sus aviones, según su tipo. La reforma del ET, como siempre, resulta la más compleja, por cuanto exige un acomodo a la realidad muy exigente en medios y capacidades.

- Finalmente, el reciente Reglamento de 2007 acoge plenamente la funcionalización de las FAS. Su organización es por las funciones que tengan encomendadas, centrando todo su esfuerzo en su realización. Por otro lado, insiste en los criterios de unidad de mando, combinabilidad y conjunción entre todas ellas; se trata de crear una suerte de sistema único que muestra sus diferentes caras según cuál sea la misión que se le encomienda. Y ello sin romper —el art. 8 de la Constitución no lo permite- la división tradicional en ET, EA y Armada. Aunque el JEMAD se constituye en el jefe militar máximo de todas las FAS, luego se crea, bajo su dependencia, el Mando de Operaciones. Se trata del órgano de la estructura operativa responsable de realizar el planeamiento y la conducción operacional (operaciones militares sin - pero bajo-dirección política directa), así como el seguimiento de los planes operativos y las operaciones militares que se le encomienden. También es el responsable de realizar el planeamiento y la conducción de aquellos ejercicios conjuntos y combinados que se determine. A tal efecto, el Mando de Operaciones está constituido, con carácter permanente, por la Comandancia y el Estado Mayor del Mando de Operaciones y se encuentra integrado orgánicamente en el Estado Mayor de la Defensa. Lo dirige un Comandante del mando de operaciones. Para la acción específica de que se trate se crean otros dos órganos, en el tenor literal del Reglamento: los «Mandos conjuntos» y el mando de la «Fuerza específica», cuya misión es dirigir «las capacidades militares proporcionadas por más de un ejército que, agrupadas bajo una autoridad, son integradas para cumplir una misión determinada de carácter táctico, en una zona concreta y limitada en el tiempo». 
B) Y la mágica aparición de la Unidad Militar de Emergencias.

Cuando antes señalaba que los ejércitos han dejado — por orden de la superioridad - de realizar funciones que han ido asumiendo los poderes civiles y, con ello, han perdido gran parte de su capacidad para remediar los problemas cívicos, no estaba del todo acertado. El Real Decreto 416/2006, de 11 de abril, además de hacer una profunda - y necesaria - reforma de la organización y despliegue de la fuerza, creó la Unidad Militar de Emergencias (UME).

Se trata de una ambiciosa unidad militar, dependiente de Presidencia del Gobierno, compuesta por un Cuartel general y una agrupación de medios aéreos, junto con un regimiento de apoyo, situados en Torrejón de Ardoz (Madrid), y cinco batallones combinados de ingenieros, especialistas en emergencias tecnológicas, NBQR e intervención, situados en otros tantos lugares. Dejando de lado lo suicidamente ambicioso de mantener activados cinco batallones (unos 4.500 soldados) cuando apenas hay efectivos para cubrir a las unidades principales de la fuerza, muchas de ellas empeñadas en misiones internacionales, la UME plantea varios problemas, digamos, conceptuales.

La conexión de la UME con la nueva Ley consiste en que la disposición adicional 5. ${ }^{\mathrm{a}}$ LODN prevé que se otorgue el carácter de «agente de la autoridad» a los militares de la UME, de manera general, además de otorgársele a los militares que actúen en las acciones previstas en esa misma Ley. Es decir, como dice su artículo 16, en aquellas misiones en las cuales las FAS pueden colaborar con las FCS, entre las que se incluyen, precisamente, las misiones típicas para las cuales se ha creado la UME. Sin entrar a valorar la capacidad de las FAS para prestar estas acciones y la necesidad de su colaboración, se suscita la duda de si es preciso otorgarles este carácter cuando ya existen fuerzas policiales cuyas misiones, doctrina, forma de despliegue territorial e, incluso, medios son también idóneos para este tipo de actuaciones. Otorgarles esta naturaleza implica realizar las siguientes preguntas: ¿Se va a formar a miembros de la UME y policía militar en todo el complejo sistema de leyes procesales y penales? ¿Van a cursar sus mandos las carreras que los equiparen, en esas materias y muchas otras de tipo científico, a los mandos y técnicos de la Guardia Civil o, incluso en menor medida, del CNP? ¿Se van a convertir en policía judicial en algunos casos? ¿Cómo lo harán? Cuando tenemos, especialmente, un complejo policial-militar como es la Guardia Civil que realiza todo ello a diario, no sé si resulta del todo acertado crear otro en el seno de las FAS.

Esto no nos lleva a despreciar la participación de las FAS. Antes al contrario, es precisa una mayor colaboración mutua, pues ambos brazos tienen capacidades para actuar en estas ocasiones y es preciso que así lo hagan. Pero no parece necesario otorgar el carácter de agente de la autoridad si no cuenta con el apoyo de fuerzas de la policía y, sobre todo, de la Guardia Civil. Fuerzas, además, sobre las que la propia LODN no ha querido entrar en 
sus funciones de colaboración con las FAS. Y es que, insisto, la LODN es bastante tibia en el desarrollo necesario de una verdadera doctrina de la seguridad nacional y, fruto de ello, se abren aquí otras vías de recelos y de separación, más que de colaboración e integración de esfuerzos.

\subsection{Reforma de medios y doctrinas: algunas propuestas.}

El general NARro Romero, en un excelente artículo, llega a la médula de toda la cuestión. Si nos vemos exigidos a tener unas FAS pequeñas, muy efectivas, con un alto grado de eficiencia en su gasto, sistemas, recursos y medios $^{94}$. Y, además, si las necesitamos para actuar en un panorama complejo, asimétrico, fugaz y variable, en el que las exigencias son también de ese tipo. Si todo eso es así, entonces necesitamos unas FAS profundamente conjuntas e integradas, en todos sus escalones, formas y, sobre todo, en las mentalidades. Se han hecho muchos cambios al respecto, es cierto. Leyes y decretos llenan sus exposiciones de motivos con grandilocuentes ideas sobre esta necesidad de conjunción. Pero la RED dio unos pasos al respecto que no parecen haberse cumplido ni materializado. Por todo ello creo que queda mucho, muchísimo, camino por andar. Todo esto es, siempre, muy discutible, pero nos parece preciso realizar un elenco de aspectos que podrían tenerse en cuenta:

- Formación militar integrada desde las Academias de acceso en las escalas de oficiales, mediante un curso común para los tres ejércitos, tres especiales y otro común para finalizar. Los planes de estudio pueden hacerse compatibles en gran medida. No es preciso tanto que egresen con una carrera universitaria cuanto que sean capaces de liderar las integradas FAS del futuro.

- Reducción importante de la estructura del Ministerio de Defensa, desaparición de superestructuras políticas (una Secretaría y otra Subsecretaría) y de múltiples instancias administrativas que solapan sus funciones y crean líneas muy complejas con respecto a las estructuras equivalentes de cada ejército.

- Creación de un Cuartel General conjunto único para los tres ejércitos, que asumiría muchas funciones burocráticas que hoy realiza una compleja combinación de personal civil, militar y autoridades políticas en el Ministerio de Defensa y los tres Cuarteles Generales. Aunque es el campo más avanzado, la unidad total de las estructuras de mando operativo y de formación para ese mando operativo. El JEMAD debe ser su epicentro indudable, al máximo nivel en la estructura de la defensa/seguridad ${ }^{95}$.

- Práctica desaparición de todas las estructuras territoriales funcio-

94 J. NARro Romero, "Defensa, dos grandes temas pendientes», en $A B C$ de 6 de enero de 2005, págs. 18 y 19.

95 A tenor del anteriormente estudiado Reglamento 787/2007. 
nal-burocráticas de los tres ejércitos (sobre todo ET y Armada). Cuando fuera preciso mantenerlas, caso de GIFAS, ISFAS, INVIFAS y otras entidades, bien podrían integrarse en miniórganos administrativos, adscritos al MAP, toda vez que realizan funciones puramente público-administrativas.

- Sistema único de evaluación y compras de material, tanto común como material específico. Evidentemente, se trata de uno de los temas más sensibles, por cuanto cada ejército requiere sus propios sistemas $\mathrm{u}$ otros que, pudiendo ser comunes, deben tener diferencias por su uso. Pero la obtención de medios interoperables sería, así, mucho más posible, con todas sus consecuencias de mantenimiento, recambios, etc. Deben estudiarse y evaluarse conjuntamente... y comprarlos con más agilidad a como se hace ahora; dicho sea con el permiso de la Armada.

- Reconfiguración de la fuerza de los tres ejércitos de acuerdo con unos objetivos estratégicos mucho más precisos y aquilatados. Si bien los pasos que se han dado desde el Plan Norte (1994) son enormes - y siempre con un alto coste, sobre todo en el ET-, la realidad es que no han venido acompañados de medidas reales para facilitar una configuración que haga a nuestras fuerzas verdaderamente ágiles y capaces.

- Replanteamiento serio de nuestra participación en fuerzas conjuntas de estructuras en organizaciones internacionales. A día de hoy, nuestras fuerzas están estiradas más allá de un máximo deseable, por los compromisos de misiones internacionales, por la participación en numerosas fuerzas multinacionales de dudosa eficacia. Como consecuencia, está sufriendo el mantenimiento de equipos, la rotación de unidades, el adiestramiento de los hombres y las unidades... y la propia obligación de participar en misiones prioritarias como las que marca la OTAN.

- Mejora de los sistemas logísticos propios. Muchos de los esfuerzos ahorrados en burocracia y estructuras deberían ser redirigidos a una mejora logística, en todos los niveles, que evite la excesiva dependencia de suministradores exteriores y del outsourcing, de aparente eficiencia, pero eficacia, a la postre, muy dudosa en la guerra. En todo este proceso el «Apoyo a la fuerza» ha sufrido enormemente el recorte de estructuras; sufrimiento a costa de la burocracia, ni siquiera de la Fuerza. El paradigma de la movilidad, rapidez, capacidad de despliegue y supervivencia, modularidad e integración de las fuerzas entre ejércitos debe ser una máxima de primerísima categoría, tal como insiste la RED en múltiples lugares.

- Integración con los sistemas de inteligencia propios (CIFAS), con el CNI y la Guardia civil, así como, en un grado o media diferente, dada su peculiar naturaleza, con el CNP, policías locales y autonómicas. La separación Administración civil-Administración militar, sobre todo si ésta desaparece, debería configurarse de otra manera: más cooperativa e integrada. 


\section{LA TRANSFORMACIÓN DEL PERSONAL DE LAS FUERZAS ARMADAS}

1. El personal de las Fuerzas Armadas

\section{1. ¿Ejército voluntario o ejército profesional?}

A) Panorama general.

Tanto el preámbulo de la LODN como las sucesivas leyes sobre el personal, como la $R E D$, especialmente, insisten en un punto que resulta inequívoco. Todas las nuevas realidades que tienen que ver con la defensa exigen un personal adecuado, motivado y formado. Pese a tratarse de un texto doctrinal, y no de una norma, como resumen de estas intenciones, la RED señala con rotundidad lo siguiente:

«En las FAS, incluso las altamente tecnificadas y automatizadas del futuro, el factor esencial y determinante seguirá siendo la calidad de sus recursos humanos. En ese sentido, el objetivo final de la política de personal será no sólo llegar a cubrir las necesidades cuantitativas de los Ejércitos sino, especialmente, reclutar y conservar en las FAS a un personal de calidad y en constante formación, consolidando un modelo de Fuerzas Armadas profesionales, con sus recursos humanos perfectamente integrados en una organización que actúe bajo los principios de eficacia y eficiencia» ${ }^{96}$.

Omito otras referencias, tanto de este texto como de las normas ya recogidas, por estar en esa misma línea. A continuación se nos señalan como tres grandes conjuntos de medidas que ayuden a la consecución de tales objetivos: Planificación de recursos humanos: revisión tasas de encuadramiento (tendente al 50\%), potenciación de los militares de complemento, ajustes de plantillas, personal civil técnicamente preparado, creación de una reserva. La mejora de la integración de las FAS en la sociedad, en orden a favorecer un clima del que pueda provenir más personal y, a su vez, una equiparación entre el régimen económico con los funcionarios civiles. Optimización de los recursos humanos mediante la externalización de servicios que no resulten prioritarios para la efectividad de la Fuerza, del apoyo a la fuerza y cuartel general. Implementación de medidas para la reincorporación de militares profesionales con relación temporal a la vida civil.

No son pocos los problemas de personal - sobre todo de tropa y, especialmente, de marinería- por los que hemos atravesado. Poco a poco se han ido corrigiendo las consecuencias nocivas que eran fruto de una deci-

96 Revisión Estratégica de la Defensa, pauta para la revisión núm. 1 y criterio básico núm. 9, págs. 66 y 92 (en la edición de la Revista Española de Defensa). 
sión que fue tomada con bastantes dosis de voluntarismo y precipitación ${ }^{97}$. Ahora, sin haber dejado de producirse, se presenta un problema de más calado que, pese a no manifestarse del todo, puede tener efectos muy nocivos tanto en las FAS como en la propia sociedad, así como en las relaciones entre ambas. Se trata del proceso de alejamiento, desconocimiento y «esquizofrenia» que se aprecia en las valoraciones sociales que se dan sobre las FAS ${ }^{98}$.

\section{B) Precisión conceptual.}

Hemos de dejar claro de antemano que cuatro son los grandes tipos bajo los cuales se puede acceder a las Fuerzas Armadas y en los que nos vamos a detener, brevemente, para examinar su peculiar estatus.

1) Militares de carrera con mando. Se trata de las personas que, en el grado de oficiales o suboficiales, ocupan determinados cuerpos y escalas con un régimen permanente de dedicación, ingresando mediante concursooposición en un Academia militar, donde obtienen el «empleo» o grado militar y ocupan un puesto en un cuerpo y escala, ascendiendo y cambiando sus destinos hasta la edad de retiro o la pérdida de la condición militar por diversas causas legalmente establecidas (baja voluntaria, sentencia judicial, separación administrativa del servicio por pérdida de condiciones psicofísicas o por sanción muy grave). Su régimen está en la LRPFAS de 1999 (en proceso de reforma por LCM de 2007), con un importante conjunto de normas derivadas sobre todos los aspectos de su carrera: pruebas y acceso, ingreso, evaluaciones, ascensos, destinos, haberes, derechos pasivos, vivienda, prestaciones sociales y sanitarias, etc. Régimen funcionarial distinto pero, en cierto modo, equiparable al de los funcionarios civiles. No nos vamos a detener en cada uno de esos aspectos, por lo que nos remitimos a estudios más completos y particulares ${ }^{99}$.

2) Oficiales y suboficiales de complemento. Quienes acceden a la respectiva escala de oficiales o suboficiales de complemento, con una relación temporal y limitada en cuanto a ascensos y destinos, hasta la fecha que fije su compromiso o los topes legalmente establecidos. Gran parte de su régimen se basa en el régimen general, aunque siguen normas distintas en el acceso-ingreso y la finalización del compromiso. Se vinculan mediante un compromiso que es un contrato administrativo.

97 Sobre todo ello, J. C. AlLi TurRILLAS, El soldado profesional (Estudio de su estatuto jurídico), Aranzadi, 2003.

98 Me baso en mi análisis personal sobre la recopilación que, sobre las encuestas del CIS entre 1997 y 2007, ha realizado el IEEE y que puede verse en su página (www.ieee.es). Muchas de estas apreciaciones pueden verse, estudiadas con ojo de sociólogo, en el excelente artículo de F. BERNETE, "Ejército profesional y distanciamiento civil de la defensa», en Papers, núm. 69, 2003, págs. 83-100.

99 J. C. Alli TurRILlas, La profesión militar. Análisis jurídico tras la ley 17/1999, INAP, Madrid, 2000. 
3) Tropa y marinería profesional. Está formada por quienes se alistan voluntariamente en los ejércitos para realizar una prestación temporal en un cuerpo y escala, determinado por su acceso y formación, empleándose hasta llegar a un grado determinado. En ciertos casos se puede mantener bajo esta relación de manera permanente, hasta la edad de retiro («tropa permanente»), asemejándose al régimen funcionarial de los militares de carrera. Se vinculan mediante un compromiso, cuya naturaleza jurídica es la de contrato administrativo. Este vínculo sitúa a los «soldados y marineros de tropa permanente» en una relación cuasi-funcionarial. De hecho, su régimen se halla fuera de la Ley de Tropa y Marinería, rigiéndose por la LRPFAS.

4) Reservistas voluntarios. Son quienes se vinculan en un régimen administrativo, temporal y discontinuo con las FAS para integrar algunos puestos así determinados en los ejércitos, en grado de oficial, suboficial o soldado/marinero. Aunque el régimen general aparece en la Ley de Personal, su concreción está recogida en el Real Decreto 1691/2003, de 12 de diciembre, de acceso y régimen de los reservistas voluntarios, así como las convocatorias específicas que se aprueban anualmente. Cuando entre en vigor la nueva Ley de la Carrera Militar, tendrán un capítulo específico.

No es correcto englobar bajo el epígrafe "profesional» a todas las personas que tienen una relación con las Fuerzas Armadas. En puridad y por razones que sería imposible traer aquí en su totalidad, militares profesionales son, estrictamente hablando, los que han sido definidos en primer lugar. Es decir, los militares de carrera con mando y los soldados profesionales «de tropa permanente». Ellos son los que profesan la carrera de las armas y a quienes, por lo tanto, se les presume y se les puede exigir la profesionalidad (el mejor hacer en su trabajo), como cualidad virtuosa o adjetivo ${ }^{100}$.

\subsection{El ejército voluntario.}

A) Creación y crisis del ejército voluntario.

En el año 1996 se tomó la decisión de crear un ejército de voluntarios, abandonando, así, casi dos siglos de ejército de reemplazo y toda la tradición de contar con un «ejército nacional» ${ }^{101}$. Los procesos de crisis y avatares varios por los que ha pasado este ejército no pueden ocultar, en cualquier caso, que se trata de un cambio fundamental ${ }^{102}$. Y, como consecuencia de este cambio, aún estamos pendientes de apreciar con total intensidad los cambios de mentalidad que esta transformación ha traído ${ }^{103}$.

100 J. C. Alli Turrillas, La profesión militar, cit., págs. 109 y ss.

101 Para todo ello debe verse F. Puell De la Villa, De la «leva» a la «mili», Biblioteca Nueva, 1996, e Historia del ejército en España, Alianza, 1999.

102 Me remito a J. C. Alli Turrillas, El soldado profesional, cit., capítulos 1 y 3, especialmente.

103 Panorama estratégico 2006/2007, IEEE, Madrid, 2007, págs. 29 a 35, entre otras. 
En 1998, una Comisión mixta del Congreso-Senado, después de escuchar a diversos expertos y a oficiales de enlace en los ejércitos extranjeros que tenían un ejército voluntario, como el Reino Unido, o estaban en proceso de tenerlo, como Holanda, Bélgica, Francia e Italia, elaboró un parco informe. En él se marcó una posible horquilla de soldados y mandos de entre 150.000 y 170.000 efectivos totales, de los que entre 100.000 y 120.000 serían soldados, y el resto mandos. Se animó a que la tasa de encuadramiento (número de mandos por cada soldado) se aproximara al 1/1. Y también a que se pasara, progresivamente, del gasto del $60 \%$ del presupuesto en personal y el $40 \%$ en material a los números inversos.

Se trató de un proceso muy voluntarista y algo precipitado que tomaba como base la mejora económica de España entre 1996-2000 y las perspectivas de crecimiento a partir de entonces. Olvidó —o quiso olvidar, mejor dicho- no sólo los datos sociológicos que exponía el CIS, sino, sobre todo, las perspectivas poblacionales y, por ello, el «mercado de trabajo» en años venideros. Tal y como SANDELL ha denunciado en varias ocasiones, esas dificultades estaban ahí, eran difícilmente corregibles y, en consecuencia, se chocó con ellas ${ }^{104}$. De ahí que durante los años noventa, y pese a la presión de una población que rechaza la «mili», no hubiera querido transformarse el ejército en totalmente voluntario, aunque sí se optara por el modelo mixto, como ha hecho Alemania.

Sabido es que, al igual que con las malas perspectivas demográficas generales que se daban para España a partir del 2005, la masiva entrada de inmigrantes desde los años 1995-1999, y especialmente a partir del 2000, ha trastocado mucho los datos. De esta manera, el ejército profesional ha podido cubrir su desnudez ampliando progresivamente el número de inmigrantes que pueden acceder. Primero fue un $2 \%$, ahora es un $8 \%$. De otro lado, la alta presencia de mujeres - más castigadas por el mercado civil de trabajo que los hombres-y su mejor preparación académica y formativa para el acceso a concursos-oposición en el ramo público han permitido que alcancen hasta un $11 \%$ de las FAS ${ }^{105}$. Con ambos grupos se ha podido mantener un ejército voluntario sin que éste haga una vía de agua imposible de contener ${ }^{106}$.

Son muchas las medidas que se han tomado para ir solventando los problemas puntuales de falta de reclutamiento. Costosas campañas de prensa, potenciación de la «cultura de defensa», mayor imagen, abaratamiento de

104 R. SANDELL, «Las barreras demográficas al reclutamiento militar: mínimos necesarios para mantener el número de efectivos en las fuerzas armadas», en Análisis del Real Instituto (ARI), núm. 135, 2003; también, «El reclutamiento en España en épocas de descenso demográfico: el soldado ausente», Documento de trabajo 31/2003; "Haciendo frente a la demografía: ¿Se complica el reclutamiento militar?», ARI, núm. 114, 2004. Todos ellos, documentos del Real Instituto Elcano.

105 El año pasado se creó en el seno del Ministerio de Defensa el Observatorio para la Mujer en las FAS, con el fin de evaluar y promover las mejores condiciones para el servicio de las mujeres en los ejércitos.

106 J. JoRDÁN, «El reclutamiento de extranjeros en las FAS españolas: causas y posibles consecuencias», en Inmigraciones, núm. 11, 2002, págs. 269-294. 
las condiciones de ingreso, mejora de salarios y salidas profesionales, etc. Los efectos de algunas pueden resultar ser, a medio y largo plazo, algo perniciosos. Nuestras campañas de marketing dan una imagen descafeinada, laboralista, glamourosa incluso, que ahonda en la «disonancia cognoscitiva» que se produce cuando, luego, el recluta ingresa en los establecimientos militares. La cultura de defensa se centra en las universidades, cuando en estos lugares - dejando de lado la importante labor de comprensión y afecto que pueda generar- apenas tiene fruto en personal, ni siquiera entre las escalas de complemento de oficiales, que han fracasado rotundamente. El abaratamiento de las condiciones de ingreso, aunque frenado, contribuye a la baja calidad de la tropa y al desprestigio profesional ${ }^{107}$. El exceso de insistencia en las condiciones laborales - ocupacionales, según la clásica visión de Moskos y REED ${ }^{108}$ _ favorece un clima más propio de un cuerpo de bomberos que de una milicia y socava las esencias de servicio propio de los ejércitos.

Aunque no sea únicamente por imagen, propiamente dicho, España se ha embarcado en una gran cantidad de operaciones de interposición y ayuda humanitaria, es decir, «de paz»: Bosnia, Kosovo, Afganistán, Irak, Líbano, Haití, y otras menores. Estas operaciones, demasiado simultáneas en muchos casos, han tenido y tienen a nuestras FAS en una situación de enorme dificultad, en cuanto al número de personal, tiempo, medios y economía, para realizar los ciclos necesarios de adiestramiento, de mantenimiento de medios, de reclutamiento e instrucción e, incluso, de descanso. El dinero que debería ir dedicado a maniobras y otras actividades de adiestramiento y formación se tiene que destinar a tapar los agujeros de material y envío de fuerzas al extranjero. Esto está lastrando gravemente - muy gravemente en el caso de la Armada- a la operatividad de la fuerza y del apoyo a ésta para un hipotético caso de «fuerza mayor». Si a ello unimos una lenta, torpe y superdependiente política de armamento, así como la progresiva externalización de numerosos sistemas de armas y de su mantenimiento, la situación es, cuanto menos, grave. Y es grave considerando que las FAS justifican su ser y presencia, principalmente, para un supuesto de crisis de seriedad. Pues si se trata de "ir tirando», que parece el objetivo de los sucesivos gobiernos, entonces, la tradicional y efectiva capacidad hispánica de adaptación e improvisación parece suficiente. Lamentablemente, eso es lo que está ocurriendo ${ }^{109}$.

107 Cfr. todo ello en J. C. Alui Turrillas, El soldado profesional, cit., págs. 219 y ss.

108 VV.AA. (dirs. C. Ch. Moskos y F. R. ReED), Lo militar: ¿Más que una profesión?, Ministerio de Defensa, 1991; un buen resumen puede verse en O. L. GutiéRREZ VALDEBENITO, «El soldado profesional versus el soldado ocupacional», en Air \& Space Power Journal, tercer trimestre 1993 (www.airpower.maxwell.af.mil), agosto 2005.

109 No es de extrañar, por lo tanto, que los BMR continúen volcando, por ser un vehículo al que se ha dado gran uso pero que está ya obsoleto. Tampoco que existan problemas de rotación de unidades, de helicópteros, de inhibidores y otras tantas cuestiones que tienen que ir siendo resueltas sobre la marcha. Siento decir que me sobran datos para corroborar un párrafo tan contundente. 
B) La Ley 8/2006, de Tropa y Marinería (LTM) o del «ejército voluntario».

El régimen de los soldados profesionales o voluntarios se venía regulando por la Ley de 1989 y por un Real Decreto de 1992, totalmente obsoletos. La decisión de suspender el servicio militar obligatorio se mantuvo, durante varios años, en el limbo jurídico, por cuanto ninguna norma contemplaba esta situación. Más al contrario, pertenecía al bloque de constitucionalidad - art. 1 de la LODN por mandato del 30 de la Constitución- la existencia de un ejército de reemplazo ${ }^{110}$. Algunos de los agujeros negros que tenía la regulación de la tropa y marinería fueron resueltos convincentemente por la Ley 8/2006, de 24 de abril. A esta norma se une el Real Decreto 1411/2006, de 1 de diciembre, por el que se aprueba el Reglamento de ascensos y acceso a la condición de permanente para Tropa y Marinería. Es de justicia reconocer que todo ese conjunto de garantías jurídicas y medidas sociolaborales y de servicio han creado el clima que ha favorecido un ligero repunte en el número de alistados $\mathrm{y}$, lo que es más importante, una mayor permanencia de los soldados. Como ya se dijo, la alta presencia de mujeres y el incremento del número de inmigrantes alistados también han contribuido a frenar el proceso de caída.

Los aspectos principales que se derivan de esta norma son:

- Clarificación del régimen de vinculación. Se trata de un vínculo jurídico-público especial. De ello se deriva una gran capacidad organizativa y de potestas variandi de la Administración sobre su régimen: ascensos, años de servicio, situaciones administrativas, cambios en cuerpos y escalas, etc.

- Nuevo régimen de contratos. En primer lugar, el compromiso inicial de hasta seis años, aunque se firmará y prorrogará en plazos de dos o tres años. Tras éste se puede firmar el segundo, el de larga duración, hasta los 45 años, que da lugar a un régimen especial una vez se retira: «soldado/marinero reservista de especial disponibilidad». Finalmente está el compromiso para la modalidad de tropa permanente, al que se accede desde el compromiso de larga duración, mediante concurso-oposición ${ }^{111}$.

- Carrera militar en la tropa profesional. Se ha establecido una escala de ascensos: soldado, cabo, cabo primero y cabo mayor. También se facilita el cambio de especialidad. Asimismo, se establece una reserva del 80\% para la promoción a la escala de suboficiales, previo examen y fase de enseñanza en la academia correspondiente.

— El «reservista de especial disponibilidad» es un soldado o marinero

110 Lo cual planteaba serias dudas de constitucionalidad: M. HERRERo DE MiñóN, «Dimensión constitucional de la profesionalización de las FAS», en Revista de Derecho Político, núm. 43, 1997, págs. 13 a 19, y J. C. Alli TuRrillas, El soldado profesional, cit., págs. 125 y ss.

111 Reales Decretos 1411/2006 y 1412/2006, ambos de 1 de diciembre, sobre carrera profesional de tropa y marinería y acceso a la condición de tropa permanente. 
que, tras cumplir 18 años de servicio, bajo el marco de un contrato de larga duración, finaliza su compromiso a los 45 años y queda a disposición hasta los 65 , pudiendo ejercer cualquier empleo civil, pero percibiendo una prima por ser reservista de especial disponibilidad hasta la edad de retiro señalada. Tiene unas especiales condiciones de disponibilidad y queda dado de alta voluntariamente en el régimen de ISFAS.

- Medidas, no del todo conseguidas, para facilitar la promoción laboral exterior de los soldados, aunque esta cuestión luego debe ser concretada con normas de rango inferior y mediante convenios con empresas. Y la especial baremación que les corresponde si entran a formar parte de la Administración civil. Si bien se reserva el $50 \%$ de las plazas de funcionarios civiles del Ministerio de Defensa, se establece que se hará un régimen de convenios con el resto de Administraciones territoriales. Algunas policías locales reservan hasta el $20 \%$ de sus plantillas, de acuerdo con los convenios firmados con las FAS ${ }^{112}$.

- Se prima el acceso de los soldados a la Guardia Civil y el Cuerpo Nacional de Policía, mediante varias medidas: la Academia de la GC para guardias y suboficiales reserva el $50 \%$ de las plazas a soldados profesionales. La Academia del CNP reserva un escaso 10\%. El soldado profesional puede "suspender» su compromiso - pues tiene posibilidad de vueltapara el acceso a sus respectivas Academias. Según cuál sea el resultado, podrá reincorporarse al ejército.

- A todo ello hay que unir la progresiva mejora en las condiciones salariales a partir de enero de $2006^{113}$, de seguridad social (Real Decreto 1412/2006, de 1 de diciembre, por el que se aprueba el Reglamento que establece el procedimiento para la aplicación de las medidas de protección social para los Militares de Complemento y de Tropa y Marinería) y otras medidas tendentes a favorecer la reincorporación de los soldados profesionales, sea cual sea su régimen, a las empresas privadas o a las Administraciones públicas (Real Decreto 999/2003, de 25 de julio, y varias disposiciones adicionales de la propia Ley de Tropa y Marinería).

C) Mandos de complemento.

Uno de los aspectos en que más palmariamente se manifiesta el fracaso es en el régimen de los militares de complemento y las «vueltas y revueltas» que ha sufrido, como una manifestación, en el terreno administrativo-funcionarial, del viejo apotegma militar: «orden tras contraorden es igual a desorden». El mayor conflicto se produjo en relación a su tiempo de com-

112 Es el caso de los Ayuntamientos de Madrid, Santa Cruz de Tenerife, Córdoba y A Coruña: Revista Española de Defensa, núm. 212, octubre 2005, págs. 32-33.

113 En un plan bianual que comenzó en enero de 2006 con aumentos en tropa/marinería y continuó con suboficiales y oficiales a partir de enero de 2007 (incremento de 18,6\% hasta 2008): Revista Española de Defensa, núms. 211, septiembre 2005, págs. 18-19, y 226, enero 2007 
promiso: tres años para la modalidad A, entre tres y ocho para las modalidades B y C. Podrían continuar estableciendo nuevos compromisos por dos o tres años hasta cumplir los doce años de servicio o llegar a los 38 años de edad. Para todo ello, así como para el ascenso desde su empleo inicial de alférez hasta el de capitán, y el cambio de destinos, debían ser evaluados. Pero a partir del año 2002 muchos de estos oficiales empezaron a quedarse, pues, en la calle. Dadas su edad y dificultades de encontrar salida (sobre todo los provenientes de la modalidad A), se hallaron con el problema de su salida al mercado civil de trabajo. Ante las quejas generadas por esta situación y la argüida falta de salidas profesionales, formación y esfuerzo por parte de las FAS, se permitió otro compromiso con carácter temporal (dis-

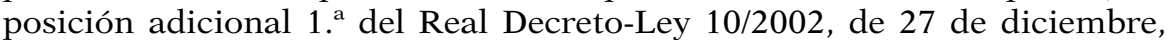
que señala: "Los militares de complemento al finalizar su compromiso podrán suscribir uno nuevo por un máximo de tres años, sin estar sometidos a las limitaciones de tiempo de servicios o edad previstas en la LRPFAS»), con un plazo de tres meses para su solicitud. Pasan una evaluación de idoneidad, tras la cual quedarán adscritos al ejército de procedencia y con el mismo tiempo de servicios, empleo y especialidad que se poseían cuando se causó baja, así como a su último destino, en los casos que haya sido solicitado y sea posible en función de las necesidades del servicio.

Estaba claro que, ante tal situación, la nueva LCM — tal y como prevenía la LTM- debía regular la situación. A ellos les dedica no un apartado de la Ley - como sería idóneo de querer darles la importancia que merecen-, sino una miserable disposición adicional, eso sí, muy amplia. Se restringe su empleo al de alférez (o sargento), por cuanto no se define si habrá militares de complemento en la escala de oficiales y, también, en la de suboficiales. Su régimen general se equipara completamente al de los militares de carrera, salvo regulaciones específicas de nivel reglamentario. El compromiso será de entre tres y ocho años, en función de la titulación y cuerpo al que se adscriban. Solamente podrán cumplir ocho años de servicio. En cuanto a su finalización, se rige - para completar el complejo modelo de delegaciones legislativas- por el artículo 10 de la Ley de Tropa y Marinería, previsto para los soldados y marineros con contratos de larga duración, con la excepción de que deben cumplir, en todo caso, su contrato inicial. Como salida adicional - más de tipo honroso que no laboralmente atractiva- se les permite la incorporación como «reservistas voluntarios».

Pues bien, todo este periplo, en apenas seis-siete años, atestigua cómo la necesidad de contar con mandos intermedios de complemento, aprovechando la formación que da el sistema civil y tras pasar un adecuado periodo de formación militar, no puede calificarse como de éxito clamoroso. Es una prueba de que serían necesarias medidas mucho más interesantes, exigentes y también costosas para contar con un buen sistema de oficiales y suboficiales de complemento: primas para estudios a cambio de un compromiso posterior, mejora del sistema de salidas civiles con empresas especializadas, formación más específica, búsqueda de perfiles interesantes para las Fuerzas Armadas, más posibilidades de ascenso. Como todo eso no 
existe, no es de extrañar que, siempre que llega el plazo de finalización absoluta del compromiso, se busquen componendas ante la presión de los afectados y acaben convirtiéndose en "funcionarios de complemento» hasta la edad de retiro.

\subsection{La reserva.}

Es bien sabido que una fuerza voluntaria necesita de una adecuada reserva de hombres, pues el desgaste del combate, la propia rotación de unidades y la falta de voluntarios clásica en situaciones de crisis —que están sufriendo en Inglaterra y Estados Unidos- generan numerosos problemas para atender el quehacer bélico ${ }^{114}$.

Cuando la LRPFAS de 1999 finiquitó el servicio militar obligatorio, el hecho de que éste se constituyera como un «deber de todos los españoles» (art. $30 \mathrm{CE}$ ) llevó a la creación de un servicio de personas que quisieran hacer la mili voluntariamente, en vez de alistarse, también voluntariamente, en el ejército profesional. No es preciso buscar y exponer las cifras de alistados. Junto con ellos formaban también los reservistas temporales, es decir, «todos los militares de carrera o de empleo que habían prestado servicio y se habían dado de baja, durante un periodo de su vida y de forma temporal». El otro tipo eran los reservistas voluntarios, que equivalía a una reserva especial, discontinua y temporal a cuya regulación más completa dedicaba bastantes artículos (167 a 177). Finalmente, regulaba la condición de reservista obligatorio, que tienen todos los españoles cuando el gobierno así lo determinara y que, de activarse, constituiría una nueva forma de hablar de un servicio militar obligatorio, aunque fuera una solución temporal.

Tras un tímido inicio del reservista voluntario, la figura se fue aceptando, hasta llegar a su potenciación, avalada por la RED, mediante el Real Decreto $1691 / 2003$, de 12 de diciembre, por el que se aprueba el Reglamento de acceso y régimen de los reservistas voluntarios. Desde entonces ha habido varias convocatorias, primero muy genéricas, luego mediante una más afinada oferta de puestos concretos. Parece haber tenido un enorme éxito en la categoría de oficiales, algo menor en suboficiales y muy poco en la de soldados y marineros (donde, se supone, aún tendrá menos ahora que existe la modalidad de «tropa de especial disponibilidad»). La LCM, aunque esté prevista para los militares de carrera, dedica el Título VI a los reservistas. Los clasifica en dos tipos: Reservistas obligatorios, que son los españoles que sean declarados como tales por el gobierno bajo un régimen especial de llamamiento y servicio, siempre de carácter supletorio a la fuerza profesional y la reserva voluntaria; y Reservistas voluntarios (ResVol), a los que dedica gran parte del título y son quienes han quedado descritos en el párrafo anterior.

El reservista voluntario accede a una plaza específica, de acuerdo con su titulación y la formación que para ella reciba. Firma un contrato por tres

114 J. C. Alli Turrillas, El soldado profesional, cit., págs. 80 y ss. 
años, en los cuales puede ser llamado a instancias del Consejo de Ministros en situaciones de crisis que exijan la movilización total o parcial de reservistas voluntarios, así como de los soldados en la reserva de «especial disponibilidad». Los reservistas pueden firmar otros dos periodos de tres años, sin sobrepasar, en ningún caso, la edad de los 50 años. El resto del articulado, muy completo, contempla todos los aspectos que, durante estos últimos años, se han visto necesitados de una especial regulación.

\section{El régimen del militar «de carrera»: Ley de la Carrera Militar (LCM)}

\subsection{Marco general.}

Apenas han pasado doce años desde la aparición de la Ley reguladora del régimen del personal militar de las Fuerzas Armadas (1999), que sustituyó, a su vez, a la Ley del personal militar profesional (1989), y se acaba de tramitar la aprobación en el Congreso de la nueva Ley que regulará la carrera militar: Ley de la Carrera Militar (en adelante, LCM). Su objeto principal - aunque no único, como veremos- es regular el régimen del personal militar profesional stricto sensu. Se complementa, por tanto, con la LTM y con el resto de normas para militares de complemento y reservistas. En otras normas queda regulado, por lo tanto, el régimen del personal civil de la defensa, que no estudiaremos.

El panorama geoestratégico, además, ha variado mucho desde 1989, cuando apareciera la primera de las leyes indicadas, como ya se ha visto. Esta cuestión, pese a ser materia propia de otros documentos, e incluso normas, es evidente que extiende sus influencias a la regulación de personal que ha de servir a la finalidad de velar por nuestra seguridad y defensa. Nuestra peculiar historia añade un factor no desdeñable en nuestra particular visión de la defensa y la seguridad. Contábamos con un ejército de leva que, además, estaba dotado, situado y organizado de una forma muy «pegada al territorio» por algunas razones no sólo geoestratégicas, sino más bien de política e historia patria. Esto ha obligado, si se quiere, a un complejo cambio de mentalidad en nuestras fuerzas militares.

Debemos enmarcar, pues, esta nueva Ley tanto entre las anteriormente estudiadas (LODN, LTM y reglamentos de organización estructural de las FAS) como entre sus antecesoras Leyes de personal números 17/1989 y 17/1999. No quiero acabar este punto sin echar un jarro de agua fría sobre esta regulación como manifestación de la actual tendencia a creer que las leyes pueden transformar la realidad; o, al menos, pueden hacerlo en los plazos que una democracia mediática puede tolerar. La necesidad de personal suficiente, la alta capacitación y ductibilidad, precisas para acomodarse a un panorama estratégico tan complejo y cambiante, no se logran con la regulación del régimen funcionarial del personal. Éste puede coadyuvar -y esperemos que así ocurra- pero no puede ni paliar ni cambiar la realidad a la que se debe. Pero, al igual que el valor se presupone, la capacidad profe- 
sional —que también se supone- puede y debe incrementarse constantemente con formación y presupuestos. Y todo esto no lo trae la Ley, por más que nos pese a los juristas.

Existe, en todo el espíritu de la Ley, un progresivo deseo de equiparación con la función pública civil, como ya denunciara PARADA. Cuando, en realidad, ha sido la función civil la que se organizó sobre estas pautas, modelos y formas de carrera y cómo las empresas civiles los imitaron ${ }^{115}$. Además, todo el conjunto de vínculos y prestaciones de los militares voluntarios están conformando un modelo de función pública degenerada, debido a la progresiva laboralización de su estatus o, como dicen los sociólogos, a que ha quedado civilinizado, al ser denominado "ciudadano de uniforme».

\subsection{Algunos aspectos destacados de la LCM.}

A) Estructura básica de la LCM.

La Ley presenta una estructura muy clásica, con 134 artículos (la 17/1999 tenía 185), 11 disposiciones adicionales y 9 transitorias, una disposición derogatoria y 8 finales. Casi podría decirse que tiene más artículos, por cuanto mantiene en vigor los artículos 150 (derechos, libertades y deberes, que no aportaba nada nuevo), 151 al 155 (Consejos asesores de personal), 160 (derechos de petición), 161 (quejas) y 162 (acceso al Defensor del Pueblo). También por lo prolijo de algunos de sus artículos. Éste es el caso del dedicado a las reglas del comportamiento militar, que ocupa más de una página del $B O E$. O la regulación de la excedencia voluntaria, con un texto con tal nivel de detalle que bien podría ser un reglamento. Pudiera haber sido una buena ocasión para clarificar todo lo relativo a la denominación de la profesión militar ${ }^{116}$. Pero parece ahondarse en la confusión, por cuanto aunque se denomina - apropiadamente- "de la carrera militar», enseguida cae en el error y realiza frecuentes y confusas remisiones legislativas tanto a la LTM como aparecen reguladas otras formas de ser militar, que no son «de carrera». También podría haber sido adecuado clarificar el complejo sistema de recursos que tienen disponibles los militares ${ }^{117}$; pero, oh curiosidad, esto es, precisamente, una de las pocas cosas que se quedan en vigor de la LRPFAS de 1999.

Parece todo ello estar dispuesto de una manera más ordenada y sistemática que la norma a la cual sustituye, que frecuentemente introducía elementos añadidos en muchos capítulos y títulos sobre otras cuestiones. Esto puede deberse a la progresiva simplificación que ha ido sufriendo la carrera militar desde la Ley de 1989 hasta la actualidad. Además, la LTM ha permi-

115 R. PARAda VázQuez, «Modelos de función pública y función pública militar», en $\mathrm{La}$ función militar en el actual ordenamiento constitucional español, Trotta, Madrid, 1995.

116 J. C. Alli TurRillas, La profesión militar, cit., págs. 101 a 109.

117 J. C. Alli TurRILlas, La profesión militar, cit., págs. 294 a 297. 
tido sacar fuera un importante número de disposiciones. Aunque el amplio número de disposiciones transitorias y adicionales señala que, también, es preciso un amplio sistema que contemple la situaciones declaradas a extinguir o necesitadas de una regulación más compleja, como luego veremos (escala de oficiales, escalas de especialistas).

Realmente, no puede decirse que sea una Ley revolucionaria; ni, en mi opinión, resultaría este adjetivo idóneo en la regulación de la carrera militar. Pensemos, por ejemplo, que la función pública civil apenas ha sufrido reformas desde las dos de 1964 y 1982, hasta la reciente reforma completa de 2007. Mientras tanto, el régimen de la función pública militar ha sufrido tres grandes reformas de régimen desde 1989. Y antes había soportado una acumulación difícil e insostenible de normas de rango menor que regulaban un complejísimo sistema de cuerpos, armas, escalas, ascensos, méritos, carreras, destinos, etc. Por razones de extensión, vamos a dejar de lado cuestiones que sería necesario tratar, como la de las plantillas, la carrera militar, etc., para destacar, solamente, algunos aspectos.

B) Las redundantes reglas del comportamiento militar, derechos y libertades, y las Reales Ordenanzas para las Fuerzas Armadas.

Uno de los aspectos que se pueden tener por más destacables de la nueva Ley es la introducción de un denso artículo 4 que introduce una suerte de código de conducta de la actuación del militar en el ejercicio de sus funciones. Consiste en quince reglas de actuación o «del comportamiento militar». Se han denominado reglas cuando, en realidad, se trata también de principios de los que, en puridad, derivarían esas reglas. Pero no se trata de un artículo que recoja, realmente, ninguna novedad. La primera regla aparecía recogida, casi con idénticas palabras, en los artículos 186, 23 y 3 de las Reales Ordenanzas (en adelante, ROFAS). La segunda es, casi textualmente, el artículo 9 de las ROFAS. La tercera aparece en los artículos 4, 22, 43 y, especialmente, en el 193. La cuarta era el artículo 5 de las ROFAS. La quinta se aprecia en el artículo 7, el 137 y, en su final, en el 43. La sexta son los artículos 137 y 139 ROFAS. La séptima aparece en el artículo 11. La octava era el 12 ROFAS. La novena aparece en los artículos 79, 28 y 87, así como en el 34. La décima es un remedo no muy acertado del artículo 34, del 84 y del 39. La undécima - en una verdadera obsesión por la obediencia debida (que también está en el art. 21 del Código penal militar)— es, de nuevo, el artículo 34 y el 84 ROFAS. La duodécima son los artículos 91 y 78. La decimotercera es el artículo 35. La decimocuarta es el artículo 44. Y, finamente, la decimoquinta es una copia literal del artículo 29 ROFAS. En un importante esfuerzo de condensación, se ha hecho un apretado resumen de los muchos detalles y matices, provenientes de las famosas Ordenanzas de Carlos III, redactadas por el Conde de Aranda, que tenían un mayor nivel de concreción.

La disposición derogatoria única de la Ley, en su punto 1, deroga seten- 
ta y seis artículos de las ROFAS y, en una desacertada redacción, deja vigentes ocho artículos. Para saber qué ocurre con los ciento cuarenta y ocho restantes, entre los cuales están muchos de los artículos renovados por el artículo 4 de la Ley actual (el Código citado), hay que ver la disposición transitoria 9. a , cuyo tenor señala que esos artículos continúan con rango reglamentario. ¿Y qué ocurre entonces con las actuales Reales Ordenanzas? Pues, según dice la disposición adicional 9. ${ }^{a}$ de la LCM, se aprobarán unas Reales Ordenanzas con rango reglamentario. Esperemos que no sea una aspiración, como ocurre con los derechos y deberes, ad calendas graecas.

Entre las partes derogadas íntegra o parcialmente está el aspecto más conflictivo de las Reales Ordenanzas: su Tratado III. En éste nos encontramos con el Título V (Deberes y derechos) casi totalmente derogado, salvo cinco artículos expresamente salvados y dos, relativamente menores (189 y 191), que quedan bajo rango reglamentario. En el Título VI (Deberes y derechos del militar de carrera) ha quedado todo totalmente derogado. Se trataba de la parte más problemática de las Reales Ordenanzas, por varias razones: la primera, porque se trataba de una regulación de aspectos necesitados de protección mediante ley orgánica, en tanto que estaban regulados por una ley ordinaria y, además, previa a la Constitución ${ }^{118}$; la segunda, porque muchas de sus regulaciones necesitaban una seria actualización mediante ley orgánica ad hoc ${ }^{119}$.

Recorramos qué ha pasado con la regulación de los derechos y deberes. Aunque el tema no estaba, realmente, en la agenda política y los conflictos eran pocos, salvo en la cuestión del «asociacionismo militar», bandera de algún grupo político y de no pocos militares, sobre todo en la reserva, la Ley 17/1999, en su disposición final 7. a , preveía que el gobierno remitiese a las Cortes una norma para regular esto antes de 2003. Luego, la LDN de 17 de noviembre de 2005 se volvía a dar un plazo de tres meses para hacerlo; es decir, a partir del 17 de febrero de 2006. También lo incumplió. La Ley de Tropa y Marinería, en su disposición final $2 .^{\mathrm{a}}$, da un plazo de tres meses para remitir un proyecto de ley de carrera; ese plazo acabó el día 27 de julio de 2006, aunque este proyecto no entró en el Congreso hasta varios meses después. Insiste esta nueva LCM, en el punto IX de su preámbulo, en que se actualizará el régimen de derechos y deberes, pero sin concretar la fecha, quizá para no volver a incumplir sus propias ilusiones. El problema es que a partir del 1 de octubre de 2007 el régimen de derechos y deberes políticos y sociales de los militares será un vago recuerdo. Salvo que éste sea el nuevo plazo encubierto iy se cumpla! Cosa que no ha ocurrido.

Considero que todas estas faltas de precisión, unidas al carácter imitati-

118 Recordemos que las ROFAS fueron aprobadas inmediatamente antes que la Constitución, aunque están sancionadas por el Rey el mismo día que ésta. Y que, precisamente por ello, el Tribunal Constitucional permite su rango ordinario en materia que, tras la Constitución, debiera haber sido orgánica.

119 Para ello pueden verse los estudios de J. Peñarrubia Iza, Presupuestos constitucionales de la función militar; D. Blanouer Criado, Ciudadano y soldado, y L. Cotino Hueso, El modelo constitucional de Fuerzas Armadas, citados. 
vo del artículo 4, ponen en un brete a una norma que, aunque claramente necesitada de un importante remozado —inclusive la necesidad de eliminar su Tratado III-, constituye parte de la esencia histórica necesaria en todo ejército. Parece que se trata de la imposición de un código ético salido de un equipo de civiles recelosos del comportamiento de los militares ${ }^{120}$. Sin darse cuenta que ese código moral estaba muy bien impregnado - y mejor cumplido- en el día a día de varias generaciones de militares en activo; por no ir más lejos. Más aún, no se trata de un mero mantenimiento de una norma por tener cierto sabor histórico - y menos aún por su carácter previo a la Constitución de 1978-, sino por ser la auténtica continuidad con las ordenanzas de los tercios españoles y los ejércitos borbónicos. Y, sobre todo, por la sabiduría comportamental que emana de ellas, la ética militar que destilan y, cómo no, por el acierto en las expresiones, e incluso por su belleza léxica. Saber e historia que no ha logrado condensar el patético artículo 4 LCM.

C) La salvadora presencia de la mujer en las FAS y su regulación.

La alta presencia de mujeres en el ejército profesional y los aspectos derivados de su naturaleza han llevado, en los últimos años, a un importante incremento de normativa civil y militar, cuya finalidad es la racionalización de horarios, la regulación de los permisos de maternidad-lactancia, las medidas antidiscriminatorias y otros factores derivados. Sin entrar a enjuiciar la cuestión de fondo, sí se aprecia una enorme complejidad de toda esa regulación, que trata de salvar dos puntos a menudo difíciles de conciliar: el bien de la madre (y de su hijo) y la familia, frente al bien del servicio ${ }^{121}$. Pues, como también dijera Moskos, familia y milicia son «instituciones voraces» que, fácilmente, entran en choque ${ }^{122}$.

Así las cosas, el preámbulo de la Ley señala que uno de sus grandes objetivos es la igualdad efectiva entre hombres y mujeres en acceso, formación y carrera militar. En una rueda de prensa inmediatamente después de la presentación de la Ley, el Ministro de Defensa destacó que nuestras FAS son las que más mujeres tienen entre sus filas. A tal efecto, el artículo 5 habla de la igualdad de trato y oportunidades. Con ese fin establece, también, que todas las medidas civiles de prevención de la violencia de género y conciliación de la vida familiar y profesional se aplicarán inmediatamente en

120 Cuando, precisamente, los dos mayores puntos en conflicto -que sí han generado problemas- son el derecho de asociación, de un lado, y, de otro, la libertad de expresión sobre temas político-militares. Pues bien, resulta que son aspectos del Título III de las ROFAS que no se han tocado en la LCM. Esto es, cuanto menos, paradójico.

121 Sobre todo ello, VV.AA., Mujer, Fuerzas Armadas y conflictos bélicos. Una visión panorámica, Monografías del CESDEN, núm. 78, 2005, in toto.

122 "La familia y el ejército como instituciones voraces», en Lo militar: ¿Más que una profesión?, cit., págs. 137 y ss., y J. P. LóPEz Novo, "El retorno de las instituciones voraces», en Claves de Razón Práctica, núm. 45, septiembre 1994, págs. 46-55. 
este ámbito. El artículo 53.6 in fine permite que reglamentariamente se atienda a la situación de embarazo durante las pruebas de acceso a la carrera militar. El artículo 85.3 da posibilidad de establecer formas de favorecer el ascenso a la mujer en situación de embarazo, parto y postparto. El artículo 96.3 permite que las mujeres que puedan encontrarse en una situación de violencia sexista puedan cambiar su destino con mayor facilidad; y el 6 permite el cambio a un destino adecuado durante el embarazo. El artículo 105.6 también prevé una excedencia voluntaria por razón de violencia sexista, con unas condiciones ventajosas que mejoran las condiciones normales de la excedencia voluntaria.

Se trata de medidas todas ellas muy en concordancia con la exigencia social de mayor protección y suponen una clara mejora de las medidas establecidas en la Ley 17/1999. Hay que recordar que, desde 1988, las condiciones jurídicas de igualdad en el acceso existen y fueron confirmadas y consolidadas por las normas posteriores. No obstante, esa igualdad sería «en igualdad de condiciones». Mas como esa igualdad coeteris paribus no siempre existe, era precisa la adopción de medidas de igualdad asimétrica, o de discriminación positiva. De ahí que se abriese paso el establecimiento de pruebas de acceso diferentes, condiciones especiales para la excedencia por cuidado de hijos, para el ascenso y el cambio de destino en esas circunstancias ${ }^{123}$. Creo aceptable entender, por lo tanto, que esta Ley regula una mejora, pero no un cambio profundo.

Pero la idea más idónea para una adecuada presencia femenina en las unidades, en una organización amplia y compleja, con infinitud de tareas, como son las FAS, es el establecimiento de un completo y detallado catálogo de capacidades y requerimientos físicos para cada puesto concreto. En este sentido, lo aceptable es elaborar un catálogo de puestos «tipo» operativos o no operativos, con su respectivo nivel físico de acceso y de mantenimiento (cosa que falla en ocasiones). Por lo tanto, quien no supere esos listones, sea hombre o mujer, no puede ser admitido o mantenerse en esos lugares. En fin, si esta cuestión es espinosa lo es porque suscita el debate de cuánta capacidad física es necesaria para cada puesto y del porqué de la menor capacidad física de la mujer: si es una cuestión natural o sociocultural. De este factor depende todo. No se pueden establecer otros baremos que aquellos que resulten idóneos para la eficacia militar de la unidad, puesto o lugar que se ocupe ${ }^{124}$.

Esta realidad, tal y como ha señalado VAN CREVELD, constituye una «gran ilusión». Los caracteres especiales de la mujer exigen unas condicio-

123 Sobre todo ello, M. Blanouer Criado, Ciudadano y soldado, cit., págs. 167-175, y L. Cotino HuEso, El modelo constitucional de FAS, cit., págs. 487 a 497.

124 Puede ser discutible que todos los fusileros tengan que cumplir un mínimo de estatura, volumen, peso, capacidad de resistencia, fuerza, etc., pues podría ser aceptable que se admitiesen algunos que no lo cumplan por abajo. Pero es lógico y aceptable que se mantenga ese estándar que evite descubrir que esos «deficientes» lastren el buen funcionamiento de la unidad, sobre todo durante un combate. De igual modo a como se hace con deficiencias o conductas que, fácilmente, podrían derivar en psicopatías en una situación de estrés o de combate; en esos casos también es lógico que, de manera general, se evite a quienes pudieran presentar ese cuadro cuando ya no hay retorno. 
nes especiales de protección, para hacer efectiva la igualdad (recordemos que la igualdad es tratar desigual a los desiguales) ${ }^{125}$. Y esto fácilmente rompe la eficacia real de unas Fuerzas Armadas. Este autor considera que ante una verdadera guerra - a la que no nos hemos enfrentado desde hace años- podría resultar inconveniente la presencia de la mujer en las FAS, al menos de una manera general y en todos los puestos de combate. Es cierto que la presencia de las mujeres en unidades de la «larga cola» logística, protegida por un poder aéreo muy capaz, la tecnificación de tantas funciones militares, y de innumerables puestos de combate o no, pero muy protegidos, favorecen su efectiva y silenciosa presencia. Pero, según nos expresa VAN CREVELD, las nuevas guerras cada vez hacen más complicada — desde todo punto de vista - la presencia de combatientes mujeres, por cuanto el tipo de combate asimétrico al que se enfrentan los ejércitos actuales es especialmente complejo, exigente y moralmente demoledor ${ }^{126}$. De ahí que la presencia de mujeres en las unidades de mercenarios, en las empresas de seguridad, en los ejércitos irregulares, guerrillas y fuerzas del tercer mundo sea muchísimo menor, si no inexistente. Hay, en torno a este inquietante debate, una profunda cuestión sobre la propia humanidad. Pero es imposible entrar a ello. Me remito, pues, a las razones de una mujer y a otros textos ya recogidos en otros lugares ${ }^{127}$.

\section{D) La innecesaria reforma de la enseñanza militar.}

La formación militar es una de las cuestiones que siempre se ha previsto reformar, pero que ley tras ley ha continuado prácticamente igual, con tan sólo unos ligeros retoques. La cuestión, en el fondo, es si es preciso reformar la formación militar, máxime cuando se estima que la formación de los militares y su propia "profesionalidad» es mejor que buena. Si su profesionalidad es buena, ¿por qué reformar la formación que a ella conduce? Puede hablarse de una constante obsesión — cuasi convulsiva- del legislador por homologar estos estudios con las carreras civiles universitarias. Pero lo que nadie debe dudar es que la universidad española no es todo lo buena que podría ser, tal y como lo expresan, una y otra vez, los estudios y encuestas que muestran que no nos encontramos, precisamente, en el

\footnotetext{
125 VV.AA., Mujer, Fuerzas Armadas y conflictos bélicos. Una visión panorámica, cit., in toto.

126 Para este autor, la presencia de la mujer en los ejércitos es un gran factor de distorsión. Sostiene que debido a la situación en la que se encuentran muchos países occidentales, sobre todo europeos, se ha favorecido la "gran ilusión» de que se puede tener un ejército efectivo y contar con mujeres en él. La realidad es ésa, que se trata de una ilusión. Dicho autor espera que no se tenga que comprobar en la realidad la dureza de sus afirmaciones: M. van CREVELD, Men, women and war, Casell \& Co., 2001, págs. 10 y ss.

127 J. B. Elshtain, Women and war, University of Chicago Press, 1987, y J. C. Alli, «Reflexiones sobre la presencia de la mujer en los ejércitos desde una perspectiva histórico-jurídica», en VV.AA., Mujer, Fuerzas Armadas y conflictos bélicos. Una visión panorámica, cit., págs. 109 y ss.
} 
ranking de las mejores del mundo ${ }^{128}$. Es indudable e innegable que hay muy buenos profesores, docentes e investigadores, así como magníficos alumnos; pero, con todo eso, la universidad no es excelente, como debería ser. Si así es, ¿por qué este continuo deseo de equiparar la formación militar con la universitaria?

Hoy por hoy, tal y como KEEGAN nos enseña, la única verdadera formación (y con ello educación media y superior, por así decirlo) es la militar ${ }^{129}$. Y por eso los más profesionales entre los profesionales - y todo ello, en el fondo, por el deber de dar la vida por la patria - han sido, son y seguirán siendo los militares. Equipararlos con los civiles ni beneficia a unos ni a otros. Más aún, la educación militar no es, ni será, una educación universitaria; es otra cosa. Pero tampoco le hace falta serlo, porque, a día de hoy, es enormemente superior desde casi todo punto de vista, salvo en los aspectos más técnicos que da la formación universitaria media o superior en los estudios que se traten. Menos aún hace falta todo ello cuando se trata de equiparar esa sólida formación y la estructura que la imparte a una universidad organizativa, académica y vitalmente decadente.

Pues bien, salvo por ligeros retoques, ni la Ley 17/1989 ni la 17/1999 establecieron un sistema muy diferente al que existía. Sí se fueron cambiando paralelamente los planes de estudios de las academias, e, incluso, se reorganizaron sus estructuras y las propias academias. Nuevamente, VAN CREVELD, en un estudio de hace unos cuantos años, saca conclusiones del proceso de universitarización de los militares estadounidenses durante los años ochenta. Su conclusión principal, dicho sea con rudeza, es que deben centrarse en sus estudios militares, evitando la dispersión intelectual de los estudios superiores universitarios que aportan sólo unos conocimientos complementarios a los necesariamente específicos de la carrera militar, dirigidos a sus fines y misiones ${ }^{130}$.

En la nueva Ley se promueve un cambio importante: la creación de unos centros docentes de la defensa, aparentemente sustitutos de los centros docentes militares de formación de las escalas de oficiales de los tres ejércitos, que se adscribirán a una o varias universidades. Así organizados, tendrán como finalidad otorgar un título oficial reconocido junto con la formación estrictamente militar. La intención no es mala si se trata de completar la formación que se obtiene en la educación militar con algunas materias civiles que, luego, permitan la obtención de un título civil. Pero habrá que tener mucho cuidado de no sobrecargar los planes de estudios de los cadetes y de no dispersar su esfuerzo principal, que debe estar dirigido a su

128 Sobre todo ello: www.arwu.org, Institute of Higher Education Sherghai. Entre las 500 mejores universidades sólo hay 9 españolas, 8 de ellas a partir del número 200.

129 Analiza la vida de grandes militares (Grant, Alejando, Wellington, etc.), enfocando especialmente la importancia de su carácter forjado en las academias militares correspondientes o en la formación militar difusa que recibieron en sus sociedades, J. KEEGAN, La máscara del mando, Ministerio de Defensa, 1991, in toto.

130 M. van CREVELD, The training of officers, The Free Press \& MacMillan, 1990, págs. 85 y ss. 
capacitación estrictamente militar. Quizá resultaría más idóneo, para ello, que tan sólo se impartieran algunas materias que se consideren esenciales para la formación humana de los futuros militares, dando, tras la finalización de sus estudios, la posibilidad de cursar algunas otras para la completa homologación de títulos. O, mejor, crear un buen sistema de becas e incentivos académicos para quienes quieran dejar la carrera militar, para que puedan acceder al mercado civil con otra formación, como hacen EE.UU. o el Reino Unido ${ }^{131}$. Al examinar estas propuestas, más bien parecen obedecer a subsanar querencias y desilusiones de personas con edad avanzada que a solucionar necesidades perentorias de los militares de carrera ${ }^{132}$.

\section{E) Las variables reformas en cuerpos, escalas y especialidades.}

La Ley 17/1989 supuso una auténtica reorganización de una enorme cantidad de cuerpos y escalas, a veces compuestos por muy pocos militares. Realmente puede afirmarse que, con todos los problemas personales que pudieran existir, era absolutamente precisa esa ordenación. La Ley 17/1999, salvo algunas precisiones, no hizo sino asentar este modelo. En algunos casos fue preciso mantener escalas y cuerpos declarados a extinguir, por existir aún militares en tales grupos. La nueva Ley apunta algunos cambios importantes:

1) El primero es la desaparición de los cuerpos de especialistas de los tres ejércitos. Sus componentes pasarán a formar parte del Cuerpo general de cada ejército, con especialidades que acojan su peculiar formación, capacidades y oficios. La disposición transitoria 4. ${ }^{a}$ dedica nada menos que dos páginas a regular el proceso de integración, que, en todo caso, no se sustanciará hasta 2009. La complejidad de esta incorporación hará este proceso lento y complejo. Y con ello no se evitarán problemas de acomodación de plantillas, de ascensos y prevalencia en los destinos.

2) La segunda es la desaparición de la escala de oficiales (escala media en la Ley 17/1989) y su integración en la escala (superior) de oficiales. En la progresiva equiparación de la carrera militar a los sistemas funcionariales civiles, la escala superior equivale al grupo A de funcionarios (grado de licenciado, arquitecto o ingeniero), en tanto que la escala media corresponde al grupo B (diplomado o ingeniero o arquitecto técnico). Para el acceso al primer grupo se requiere tener ese nivel académico, por lo que el ingreso desde los empleos de suboficiales es de suponer que exija pasar por los nuevos centros universitarios militares y obtener ese título para acceder a la escala superior (que será una escala única de oficiales). Con las Leyes 17/1989 y 17/1999 la presencia de esta escala media suponía un escalón intermedio

131 «Army career guide to Officers», Army \& Territorial Army, en www.armyjobs.mod.uk (septiembre 2007).

132 A este respecto es interesante L. J. MATTHEws, «Anti-intelectualism an the Army profession», en VV.AA., The future of the Army profession, cit., págs. 61 y ss. 
(aunque final), que hoy sería preciso articular — aunque sea de otro modoen la escala superior.

Se trataba de una reforma necesaria, por cuanto la imposibilidad de distinguir funciones y la existencia de dos escalas con los mismos empleos, en que una tenía su tope en el grado de Teniente Coronel, suponía un cierto agravio comparativo e, indudablemente, una restricción de la carrera en condiciones de igualdad de méritos y capacidad ${ }^{133}$.

3) Con la Ley de 1989 desaparecieron las clásicas «Armas» (infantería, caballería, ingenieros y artillería). Mas como la necesidad de atender la especialidad que éstas abarcaban continuaba existiendo, se crearon las especialidades. En principio, cada militar, en su perfil militar, tenía una especialidad fundamental y, quizá, alguna «complementaria», tal y como diversos reglamentos, sucesivamente, fueron regulando. La Ley busca favorecer sobre todo el cambio de especialidad, con la posibilidad de adquirir una nueva a lo largo de la carrera. Y esto se hace para que, a partir de los empleos medios de cada escala (Comandante-TCol y Brigada), se pueda acceder a funciones diferentes a las propiamente operativas.

4) La nueva Ley regula los cometidos profesionales creando otra especie de definición denominada «capacidades profesionales», con la que se hace referencia a la combinación del cuerpo, la escala y la especialidad. Es de suponer que esta capacidad, cometido o perfil será preferente para ocupar los puestos de trabajo con la clasificación de capacidades que establezcan reglamentariamente.

\section{F) El delicado régimen de ascensos.}

Uno de los aspectos más novedosos de la Ley es, sin duda, el cambio en el sistema de ascensos. Lejos quedan ya las discusiones sobre la idoneidad del sistema de antigüedad puro frente a los modelos combinados de calificación por méritos variados y la «cuestión artillera». La antigüedad como sistema ha quedado casi totalmente abolida. Si el ascenso por antigüedad favorece la lasitud, el sistema de promoción por méritos, en cuanto exige la evaluación de éstos y la preferencia entre ellos, es campo abonado para la $\operatorname{arbitrariedad}^{134}$. Si únicamente queremos que exista una cierta arbitrariedad será preciso un sistema de transparencia, recursos y una tabla de méritos que no permitan la más leve duda ${ }^{135}$. Si esto es posible. Por antigüedad, exclusivamente se asciende a Capitán desde Teniente, a Sargento Primero desde Sargento, y a Cabo desde soldado. El resto de ascensos se realizará por un nuevo sistema denominado «clasificación», ambiguo término bajo el

133 J. P. Díaz-Pache McKinlay, Luces y sombras del nuevo régimen de personal militar, Monografía del VIII Curso de Estado Mayor, Escuela Superior de las FAS y CESEDEN, 2007, págs. 60 a 65.

134 J. P. Díaz-Pache McKinlay, Luces y sombras del nuevo régimen de personal militar, cit., págs. 70 y ss.

135 Estudiado, todo ello, en J. C. ALLI, La profesión militar, cit., págs. 319 y ss. 
cual subyace una reestructuración del escalafón poniendo en relación los méritos de los candidatos con los requerimientos del empleo superior.

Un análisis rápido nos lleva a pensar que, probablemente, para evitar problemas entre los candidatos, se establecerá un sistema flexible en el que - prácticamente - todas las evaluaciones prosperen. Pues si se hace un régimen muy complejo en el que se establezca una fuerte prelación se generará una enorme conflictividad, dado que los criterios a utilizar se basan en una gran dosis de discrecionalidad técnica, tal y como señalamos en La profesión militar ${ }^{136}$. El establecimiento del sistema de ascenso por elección para los Coroneles, Suboficiales mayores y Cabos mayores introduce, junto con la elección de los respectivos Jefes de Estado Mayor, una mayor discrecionalidad política en el sistema, apartándose de los criterios más técnicos que podían prevalecer con el sistema de selección anterior y con los informes preceptivos de los Consejos superiores militares. Sin dudar de la profesionalidad de los ascendidos, lo único que sí podemos garantizar es que, con estas medidas, existirá una cúpula más dúctil en todas las escalas.

\section{Conclusión}

Todo el proceso de cambio en el entorno de seguridad está adecuadamente descrito en la Revisión Estratégica de la Defensa, aunque quizá necesitara ser, de verdad, revisada para adaptarla a algunas novedades. Y si está convenientemente reflejada en ese lugar es porque, mejor o peor, los creadores de las doctrinas militares nacionales son muy conscientes de esos cambios, de sus consecuencias inmediatas e, incluso, de los requerimientos necesarios para asumirlos o evitarlos, según sea el caso.

La legislación sobre defensa nacional y organización militar estaba anclada en una situación muy diferente, y aunque sí había habido numerosos cambios en la orgánica de los ejércitos y en el régimen del personal militar, no se había tocado para nada la LODNOM ni se había normado adecuadamente para el magno cambio que supuso la creación de un ejército voluntario. En ese plano hay que situar, pues, la reforma de la LODN y la LTM. No así la LCM, que es una evolución de las anteriores de 1989 y 1999. En todo caso, el entorno geoestratégico y la «evolución de los asuntos de seguridad», que no «revolución en los asuntos militares», exigían una transformación a ese nuevo entorno. Y esa adaptación la tenían que hacer esas leyes. Pero, como dice el viejo refrán, "para este viaje no se necesitaban alforjas», o, si se prefiere, al menos «estas alforjas». Porque el marco establecido por la nueva LODN no es, en modo alguno, el adecuado para todo este cambio.

136 En previsión de las posibles complicaciones en ascensos, destinos, situaciones y evaluaciones, el artículo 135 señala que el silencio administrativo es de carácter negativo; aunque esto no salva, por supuesto, la posibilidad del doble silencio en alzada, que lo convierte en positivo, como bien conoce aquel grupo de soldados profesionales que pudo acceder a la condición de permanente por esta «doble» desidia del órgano administrativo correspondiente. J. C. Alli TurRillas, La profesión militar, cit., págs. 319 a 334. 
Sin repetir argumentos ya escritos, el marco normativo exigía una verdadera transformación desde el desfasado, obsoleto e inoperante concepto de «defensa nacional» hacia el mucho más complejo, atractivo y real de «seguridad nacional». De esa arcaica conceptualización adoptada se deriva toda una ristra de formas, organismos y funciones de perfil bajo. Y cuando se ha atrevido a regular cuestiones más complejas, como los fines y misiones de las FAS, o participación de otras instituciones en la defensa compartida - GC, CNI, entre otros-, su texto adolece de esta falta de identidad existencial: de ahí sus errores y sus vacíos, ya descritos.

Todo ello tiene enormes consecuencias en el resto de regulaciones derivadas de la LODN y, sobre todo, de la concepción general de nuestra seguridad. La LTM, en cambio, introduce elementos interesantes para la mejora del ejército profesional. Esto, en cambio, no puede decirse de la LCM, norma que parece abundar en importantes fallas de la regulación pasada de la carrera militar, pues ha preferido centrar sus novedades en aspectos colaterales, como la derogación de las Reales Ordenanzas, que dejan en entredicho aspectos muy importantes del estatus clásico de los militares. Además, aspectos verdaderamente importantes, como los derechos y deberes, se dejan, de nuevo, en una suerte de limbo político y jurídico; quizá porque queman demasiado. Esperemos que todo ello no sea, como teme el profesor PARADA, el comienzo del fin de la verdadera carrera de las armas ${ }^{137}$.

137 R. PARADA, «Prólogo» al libro El soldado profesional, cit., págs. 25 y 26. 


\title{
RECURSO DE CASACIÓN Y UNIDAD DEL ORDENAMIENTO JURÍDICO
}

\author{
RAFAEL GÓMEZ-FERRER RiNCÓN \\ Profesor de Derecho Administrativo \\ Universidad Nacional de Educación a Distancia
}

I. Introducción.-II. El proyecto de reforma del recurso de casación en el proceso contenciosoadministrativo.-III. La regulación de la casación en la legislación vigente.-IV. Principios y derechos constitucionales a los que sirve la regulación vigente; funciones de la casación.V. Crítica del proyecto de reforma.-VI. Reflexión final: recurso de casación e interés casacional.

\section{RESUMEN}

El presente trabajo constituye una reflexión sobre el proyecto de reforma del recurso de casación en el proceso contencioso-administrativo; proyecto con el que esencialmente se pretende que el recurso de casación contra las resoluciones dictadas por las Salas de lo Contencioso-Administrativo de los Tribunales Superiores de Justicia pase a ser un recurso para la unificación de doctrina. Después de exponer la regulación de la casación en la legislación vigente, así como los principios y derechos constitucionales a los que sirve dicha regulación, se critica dicho proyecto de reforma y se afirma que el cambio podría presentar serios problemas de constitucionalidad; en particular, y sin que puedan descartarse otros motivos, por no respetar las exigencias derivadas del principio de unidad. El trabajo concluye con una reflexión final en relación con una propuesta alternativa como es la de convertir al interés casacional en razón única para poder recurrir una resolución judicial en casación.

Palabras clave: jurisdicción contencioso-administrativa; recurso de casación; interés casacional; principio de unidad.

\section{ABSTRACT}

The present paper constitutes an analysis on the project of reform of the cassation appeal in the contentious-administrative process; a project which essentially intends to transform the cassation appeal against the resolutions passed by the Superior Courts of Justice into an appeal for the unification of doctrine. After describing the regulation of the cassation appeal in the current legislation, as well as the constitutional principles and rights which it serves to, the paper criticizes the project of reform and states that it may incur in serious constitutionality problems; specially, and without ruling out other reasons, because it does not respect the demands derived from the principle of unity. The paper concludes with a final reflection on relation to an alternative proposal which aims to convert the cassational interest in the unique reason to appeal a judicial resolution in cassation.

Key words: contentious-administrative jurisdiction; cassation appeal; cassational interest; principle of unity. 